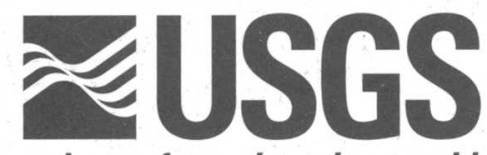

science for a changing world

\title{
Geohydrology and Water Quality at Shanghai Spring and Solid-Waste Management Units at the Fort Leonard Wood Military Reservation, Missouri, 1995-98
}

Water-Resources Investigations Report 00-4178

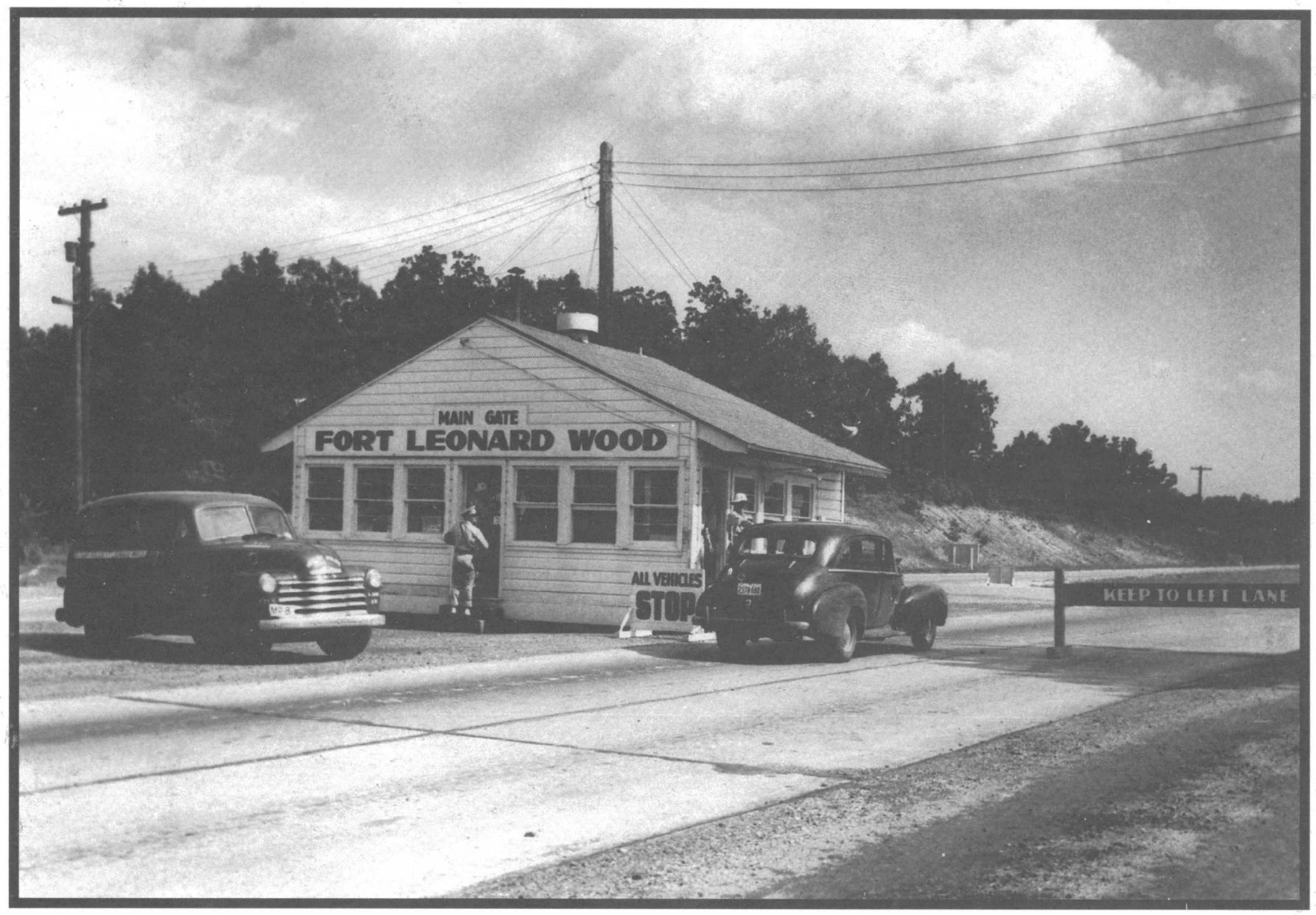

Prepared in cooperation with the Directorate of Public Works, Environmental Division,

Fort Leonard Wood Military Reservation 
Cover Photograph: Main gate at Fort Leonard Wood Military Reservation about 1950. Photograph courtesy of the Public Affairs Office, Fort Leonard Wood, Missouri. 
U.S. Department of the Interior

U.S. Geological Survey

\section{Geohydrology and Water Quality at Shanghai Spring and Solid-Waste Management Units at the Fort Leonard Wood Military Reservation, Missouri, 1995-98}

By John G. Schumacher and Jeffrey L. Imes

Water-Resourcés Investigations Report 00-4178

Prepared in cooperation with the Directorate of Public Works,

Environmental Division,

Fort Leonard Wood Military Reservation 


\section{U.S. DEPARTMENT OF THE INTERIOR}

\section{BRUCE BABBITT, Secretary}

\section{U.S. GEOLOGICAL SURVEY}

Charles G. Groat, Director

The use of firm, trade, and brand names in this report is for identification purposes only and does not constitute endorsement by the U.S. Geological Survey.

\section{District Chief}

U.S. Geological Survey, WRD

1400 Independence Road

Mail Stop 100

Rolla, Missouri 65401

\author{
U.S. Geological Survey \\ Branch of Information Services \\ Box 25286 \\ Denver, CO 80225-0286
}




\section{CONTENTS}

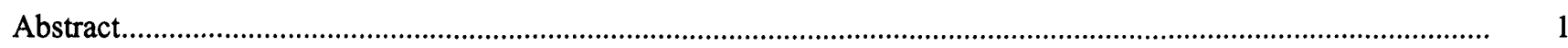

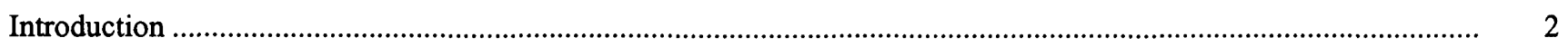

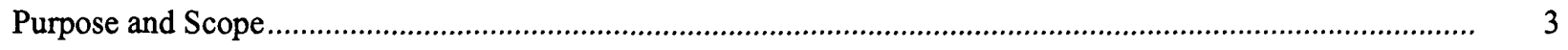

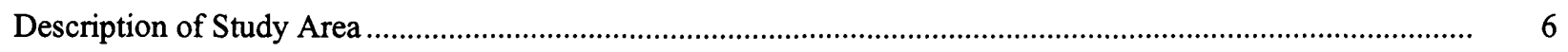

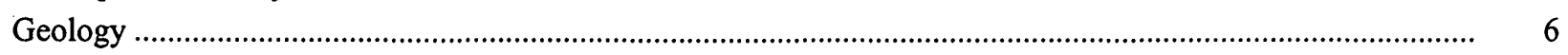

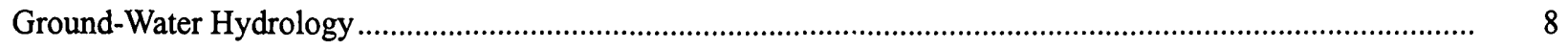

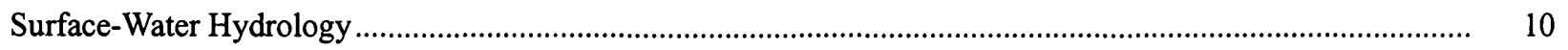

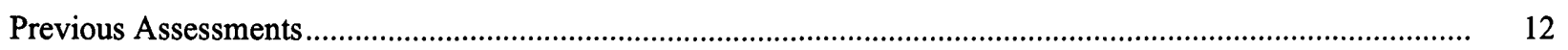

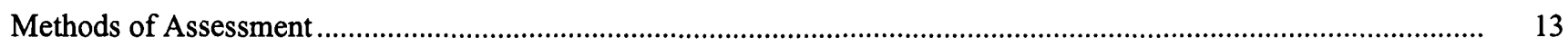

Soil and Streambed Sediment Sampling and Analysis..............................................................................

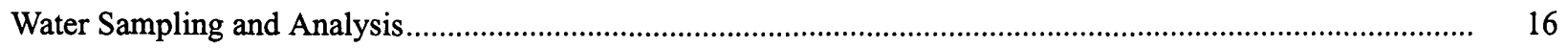

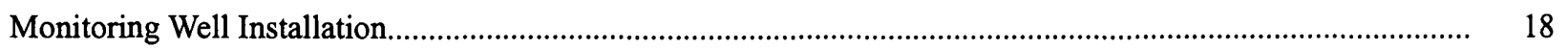

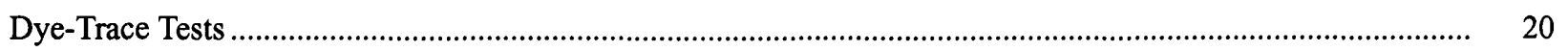

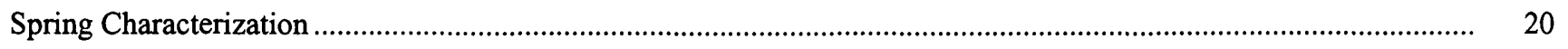

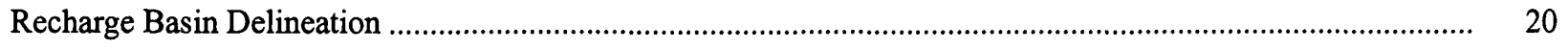

Geohydrology and Water Quality of Shanghai Spring ............................................................................. 23

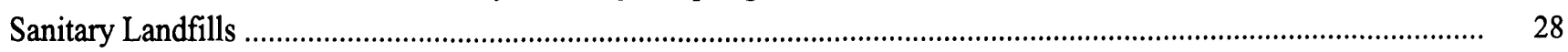

Solid-Waste Management Unit FLW-002 _....................................................................................... 30

Solid-Waste Management Unit FLW-003 ................................................................................................. 40

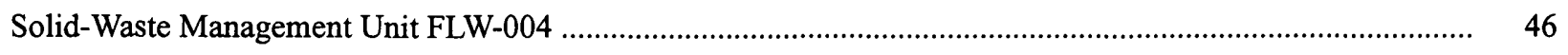

Solid-Waste Management Unit FLW-005 ….............................................................................................. 47

Solid-Waste Management Unit FLW-059 _.............................................................................................. 48

Solid-Waste Management Unit FLW-060 ............................................................................................. 53

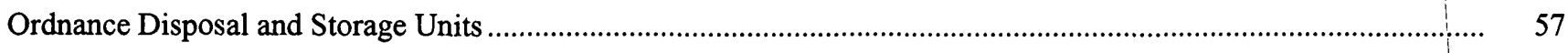

Solid-Waste Management Unit FLW-030 _..................................................................................... 57

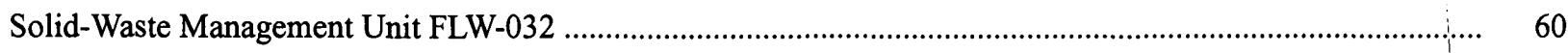

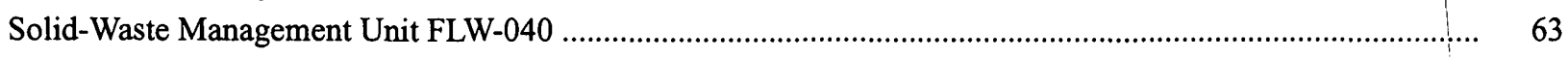

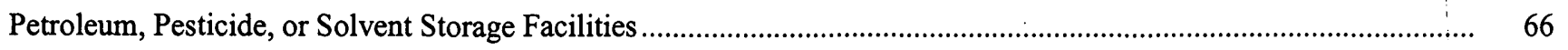

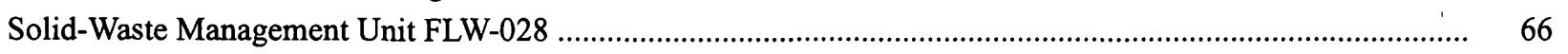

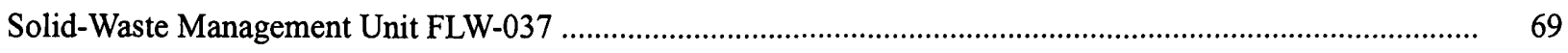

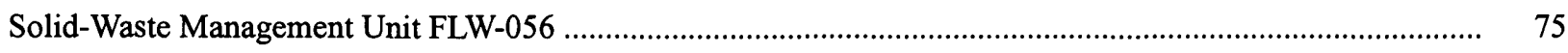

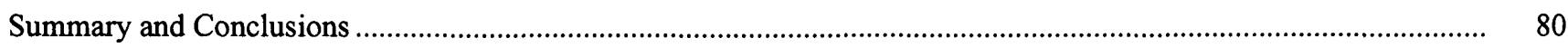

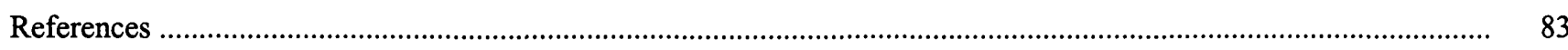

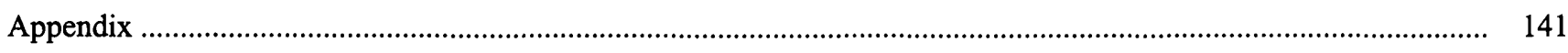




\section{FIGURES}

1. -5. Maps showing:

1. Location of the Fort Leonard Wood Military Reservation and selected solid-waste management units

2. Altitude of the regional water table and location of springs and selected solid-waste management units at the Fort Leonard Wood Military Reservation and vicinity

3. Bedrock geologic formations at the Fort Leonard Wood Military Reservation and vicinity.

4. Location of sinkholes, springs, and selected solid-waste management units at the Fort Leonard Wood Military Reservation and vicinity

5. Recharge basins of major springs and injection and recovery points for dye-trace tests in and near the Fort Leonard Wood Military Reservation and vicinity

6.-12. Graphs showing:

6. Spectral analysis of fluorescent material extracted from activated charcoal packets placed in Miller Spring during dye-trace test T103-09

7. Concentrations of chloride and nitrite plus nitrate (as nitrogen) in samples from Shanghai Spring compared to concentrations reported in samples from other springs in the Gasconade River Basin .

8. Instantaneous discharge and specific conductance at Shanghai Spring, March 28, 1997, through February 28, 1998

9. Instantaneous discharge, specific conductance, and concentrations of Eosine OJ and

Rhodamine WT dye and tetrachloroethene (PCE) in water samples from Shanghai

Spring, May 21 through June 10, 1997.

10. Instantaneous discharge, specific conductance, and tetrachloroethene (PCE) concentration in water samples from Shanghai Spring, June 12 through June 25, 1997

11. Instantaneous discharge and specific conductance at Shanghai Spring, August 16 through August 26, 1997

12. Instantaneous discharge, specific conductance and concentrations and instantaneous loads of calcium, chloride, and boron in water samples from Shanghai Spring, May 25 through July 5,1997

13. Map showing principal features and location of sampling sites at solid-waste management unit FLW-002.

14. Range of percent clay, percent total organic carbon, and selected trace-element concentrations in soil samples from solid-waste management units.

15. Range of percent clay, percent total organic carbon, and selected trace-element concentrations in streambed sediment samples from solid-waste management units

16. Trilinear diagram depicting molar equivalents of major ions in ground-water samples from solid-waste management unit FLW-002

17. Map showing principal features and location of sampling sites at solid-waste management units FLW-003, FLW-004, and FLW-005

18. Map showing location of monitoring wells and leachate seeps at solid-waste management units FLW-003, FLW-004, and FLW-005

19. Aerial photographs of solid-waste management units FLW-003, FLW-004, and FLW-005 taken during $1955,1964,1976$, and 1986

20. Map showing principal features and sampling sites at solid-waste management unit FLW-059..

21. Aerial photographs of solid-waste management unit FLW-059 taken during 1955, 1964, 1975, and 1986.... 


\section{FIGURES-Continued}

22. Map showing location of temporary monitoring wells and altitude of shallow ground water at solid-waste management unit FLW-059

23. Map showing principal features and location of sampling sites at solid-waste management unit FLW-060

24. Aerial photographs of solid-waste management unit FLW-060 taken during 1938, 1955, and 1967

25. Map showing location of sampling sites at solid-waste management unit FLW-030

26. Aerial photographs of solid-waste management unit FLW-030 taken during 1942 and 1955

27.-31. Maps showing:

27. Principal features and location of sampling sites at solid-waste management unit FLW-032.

28. Location of sampling sites at solid-waste management unit FLW-032

29. Location of soil, sediment, and ground-water sampling sites at solid-waste management unit FLW-040

30. Location of surface soil and subsurface soil samples at solid-waste management unit FLW-028 ......

31. Location of bed sediment sampling and runoff sampling sites at solid-waste management unit FLW-037

32. Schematic diagram of the old pesticide storage building 2206 (FLW-037) and locations of slab, fill and soil sampling sites

33. Map showing approximate location and principal features at solid-waste management unit FLW-056

34. Map showing field determined concentrations of tetrachloroethene (PCE) and trichloroethene (TCE) in subsurface soil samples from FLW-056

\section{TABLES}

1. Summary of types of matrices sampled and analyses performed during previous assessments of selected solid-waste management units at the Fort Leonard Wood Military Reservation

2. List of physical properties and chemical or mineralogical analyses performed on environmental samples collected from selected solid-waste management units

3. Completion data for monitoring and temporary monitoring wells installed at solid-waste management units ....

4. Physical properties and concentrations of chemical constituents and bacteria in water samples collected from Shanghai Spring between 1925 and 1998

5. Selected physical properties and estimated concentrations of tetrachloroethene (PCE) in water samples collected from Shanghai Spring during 1997

6. Physical properties and concentrations of inorganic chemical constituents in soil samples from solid-waste management units

7. Physical properties and concentrations of inorganic chemical constituents in streambed sediment samples from solid-waste management units

8. Concentrations of pesticides detected in soil and streambed sediment samples from solid-waste management units

9. Estimated concentrations of chlorinated solvents in soil-gas samples from solid-waste management unit FLW-002

10. Physical properties and concentrations of inorganic chemical constituents in ground-water samples from selected solid-waste management units and Shanghai Spring

11. Concentrations of volatile organic compounds, semi-volatile organic compounds, and pesticides in water samples from solid-waste management units and Shanghai Spring 


\section{TABLES-Continued}

12. Physical properties and concentrations of inorganic constituents in surface-water samples from solid-waste management units

13. Reporting limits for characteristics and selected pesticides determined in building material samples from solid-waste management unit FLW-037.

14. Characterization of building material, slab, and fill samples from solid-waste management unit FLW-037

15. Subsurface soil samples collected from solid-waste management unit FLW-037.

16. Estimated discharge and concentration of selected physical properties, pesticides, and inorganic constituents in runoff samples from solid-waste management unit FLW-037.

17. Estimated concentrations of volatile organic compounds detected in soil and water samples collected during the preliminary reconnaissance of solid-waste management unit FLW-056 and vicinity

18. Comparison of laboratory and field determined concentrations of tetrachloroethene (PCE) and trichloroethene (TCE) in subsurface soil samples submitted for laboratory analysis from solid-waste management unit FLW-056

19. Estimated concentrations of tetrachloroethene (PCE) and trichloroethene (TCE) in soil-gas samples from solid-waste management unit FLW-056

\section{APPENDIX}

A1. Summary for injection site and attempted recovery sites during dye-trace test T103-08.

A2. Summary for injection site and attempted recovery sites during dye-trace test T103-09.

A3. Summary for successful dye recovery at Miller Spring during dye-trace test T103-09........

A4. Summary for injection site and attempted recovery sites during dye-trace test T103-10.

A5. Summary for successful dye recovery at Shanghai Spring during dye-trace test T103-10

A6. Summary for injection site and attempted recovery sites during dye-trace test T103-11

A7. Summary for successful dye recovery at Miller Spring during dye-trace test T103-11

A8. Summary for injection site and attempted recovery sites during dye-trace test T103-12.

A9. Summary for injection site and attempted recovery sites during dye-trace test T103-13

A10. Summary for successful dye recovery at Miller Spring during dye-trace test T103-13

A11. Summary for injection site and attempted recovery sites during dye-trace test T103-14 .............................. 153

A12. Summary for successful dye recovery at Sandstone Spring during dye-trace test T103-14_......................... 154

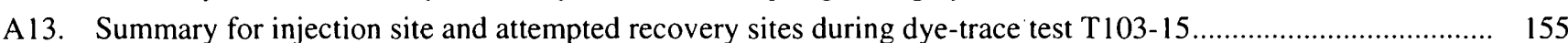

A14. Summary for injection site and attempted recovery sites during dye-trace test T103-16 ............................. 156

A15. Summary for successful dye recovery at Shanghai Spring during dye-trace test T103-16 .......................... 157

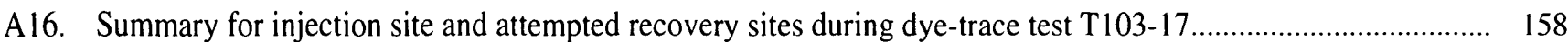

A17. Summary for successful dye recovery at Shanghai Spring during dye-trace test T103-17 _.......................... 159

A18. Summary for injection site and attempted recovery sites during dye-trace test T103-18 .............................. 160

A19. Summary for injection site and attempted recovery sites during dye-trace test T002-01 _.............................. 161

A20. Summary for successful dye recovery at Shanghai Spring during dye-trace test T002-01 ............................ 162

A21. Summary for successful dye recovery at Smith Branch during dye-trace test T002-01 ................................... 163

Sea level: In this report, "sea level" refers to the National Geodetic Vertical Datum of 1929 (NGVD of 1929)—a geodetic datum derived from a general adjustment of the first-order level nets of both the United States and Canada, formerly called Sea Level Datum of 1929. 


\title{
GEOHYDROLOGY AND WATER QUALITY AT SHANGHAI SPRING AND SOLID-WASTE MANAGEMENT UNITS AT THE FORT LEONARD WOOD MILITARY RESERVATION, MISSOURI, 1995-98
}

\author{
By John G. Schumacher and Jeffrey L. Imes
}

\section{ABSTRACT}

Results of a coordinated geohydrologic and water-quality assessment of 12 solid-waste management units (SWMUs) at the Fort Leonard Wood Military Reservation (FLWMR) indicate the release of contaminants to soil, surface water, streambed sediment, or ground water from three facilities. Soils at the former laundry and dry cleaning shop (FLW-056) are contaminated with large concentrations of the chlorinated solvents tetrachloroethene (PCE) and trichloroethene (TCE).

Analyses of subsurface soil samples using a portable gas chromatograph indicated shallow [less than $3 \mathrm{ft}$ (feet) deep] soil samples contained large concentrations of PCE [460,000 $\mu \mathrm{g} / \mathrm{kg}$ (micrograms per kilogram)] and TCE $(136,000 \mu \mathrm{g} / \mathrm{kg})$. Water samples collected from a storm drain immediately downstream from FLW-056 also contained PCE and TCE. The site lies within the contributing recharge area of Shanghai Spring about 4.5 miles to the north, and concentrations of PCE [0.6 to 1.8 $\mu \mathrm{g} / \mathrm{L}$ (micrograms per liter)] were routinely detected in water samples from this spring between 1995 and 1997. Concentrations of PCE in spring water samples increased during and immediately following runoff events indicating that infiltrating rainfall or runoff entering the unsaturated zone quickly mobilizes PCE. Because FLW056 lies within the Shanghai Spring Basin and near losing streams that are connected to the spring, the site probably is contributing to the PCE contami- nation at the spring. An estimated 5 to 10 gallons of PCE are discharged from Shanghai Spring each year.

Results of this study also confirm the release of pesticides from the former pesticide mixing and storage building (FLW-037) to nearby soils and stream sediments. Large concentrations of the organochlorine pesticides chlordane $(45,000$ $\mu \mathrm{g} / \mathrm{kg})$, DDT $(280,000 \mu \mathrm{g} / \mathrm{kg})$, DDD $(27,000$ $\mu \mathrm{g} / \mathrm{kg}), \mathrm{DDE}(24,000 \mu \mathrm{g} / \mathrm{kg})$, and dieldrin $(5,100$ $\mu \mathrm{g} / \mathrm{kg}$ ) were detected in shallow (less than $2 \mathrm{ft}$ deep) subsurface soil samples around the building and samples of fill directly beneath the building slab. Two streambed sediment samples collected about 500 and 2,500 ft downstream from FLW-037 also contained large concentrations of chlordane (550 and 1,900 $\mu \mathrm{g} / \mathrm{kg}$ ), DDT (480 and $940 \mu \mathrm{g} / \mathrm{kg}$ ), DDD (330 and 1,200 $\mu \mathrm{g} / \mathrm{kg}$ ), and DDE (170 and $250 \mu \mathrm{g} / \mathrm{kg}$ ). Trace concentrations of organochlorine pesticides also were detected in stormwater runoff collected $500 \mathrm{ft}$ downstream from FLW037.

Six of the 12 SWMUs investigated were abandoned sanitary landfills (FLW-002, FLW-003, FLW-004, FLW-005, FLW-059, and FLW-060). Except for FLW-002, little or no ground-water quality data exists to evaluate the release of contaminants from these abandoned landfills to ground water. Analyses of water samples from monitoring wells at FLW-002 indicate the release of contaminants from this site to the regional water table more than $170 \mathrm{ft}$ below the land surface. Samples from wells monitoring perched water in the overburden and shallow bedrock contained 
larger than background concentrations of many inorganic constituents and concentrations of vinyl chloride (VC) (as large as $13.6 \mu \mathrm{g} / \mathrm{L}$ ) exceeding the Missouri Ground Water Standard of $2 \mu \mathrm{g} / \mathrm{L}$. Concentrations of volatile organic compounds (VOCs), including PCE and VC also were detected in the regional water table beneath the site. Soil-gas samples from the southeastern part of the FLW-002 contained detectable concentrations of cis-1,2-Dichloroethene and VC indicating that chlorinated solvents were disposed in the landfill. Seep samples from abandoned sanitary landfills FLW-003, FLW-004, and FLW-005 also contained $\mathrm{VC}$ (as large as $131 \mu \mathrm{g} / \mathrm{L}$ ) and an overburden monitoring well contained a trace concentration of PCE $(0.2 \mu \mathrm{g} / \mathrm{L})$ indicating that chlorinated solvents also were disposed in these landfills. A positive dye-trace test was conducted between a monitoring well at FLW-005 and Sandstone Spring about 3 miles to the northeast. Water samples from Sandstone Spring contained larger than background concentrations of sodium, chloride, and total nitrite plus nitrate; however, without additional ground-water monitoring the source of these constituents can not be unequivocally attributed to the SWMUs FLW-003, FLW-004, or FLW005.

Four of the SWMUs investigated were sites formerly used for the open burning/open detonation of ordnance (FLW-030 and FLW-032), storage of small arms ammunition containers (FLW040), or firefighter training (FLW-028). Because of the potential of unexploded munitions, soil samples were not collected at FLW-030 and FLW-032. Except for larger than background concentrations of copper and lead in a streambed sample from FLW-030, and isolated VOCs detected in a shallow (3 ft deep) subsurface sample from FLW-028, no release of contaminants attributed to activities at these SWMUs was detected; however, limited ground-water data exists for these sites.

Dye-trace tests indicate that a substantial part of the north-central part of the FLWMR, including the location of 6 of the 12 investigated SWMUs (sanitary landfills FLW-003, FLW-004, FLW-005, fire training area FLW-028, the ammunition container storage area FLW-040, and the old base laundry and dry cleaning shop FLW-056), lie within the Shanghai Spring or Sandstone Spring recharge basins. The water quality of Shanghai Spring has been affected by effluent from the FLWMR wastewater treatment plant and other unidentified sources. The average concentrations of dissolved sodium $[7.3 \mathrm{mg} / \mathrm{L}$ (milligrams per liter)], dissolved chloride $(11.6 \mathrm{mg} / \mathrm{L})$, dissolved fluoride $(0.2 \mathrm{mg} / \mathrm{L})$, total nitrite plus nitrate as nitrogen $(1.6 \mathrm{mg} / \mathrm{L})$, total phosphorus $(0.13$ $\mathrm{mg} / \mathrm{L})$, and dissolved boron $(31 \mu \mathrm{g} / \mathrm{L})$ in water samples collected from the spring between 1995 and 1997 were larger than background. Water samples from the spring also contained detectable concentrations of the pesticides prometon and simazine $(0.008$ and $0.006 \mu \mathrm{g} / \mathrm{L})$, in addition to PCE. Shanghai Spring responds rapidly to runoff at the FLWMR, with discharge increasing almost immediately after the onset of runoff. A delay between the increase in discharge and decrease in specific conductance values and concentrations of inorganic constituents indicates a substantial volume of primary phreatic conducts (estimated at 9 million cubic feet) supplies water to the spring orifice. Although, constituent concentrations decreased with increasing discharge, constituent loads increased with increasing discharge indicating that at high-flow conditions the larger dissolved-solids base-flow component of the spring is diluted by runoff.

\section{INTRODUCTION}

During 1980, the U.S. Department of Defense (DOD) initiated a comprehensive Installation Restoration Program (IRP) to assess and control the migration of environmental contaminants that may have resulted from past operations or disposal practices at DOD facilities. The IRP was modified after the Superfund Amendments/Reauthorization Act (SARA) was passed during 1986. This Act requires Federal facilities to adhere to guidelines and procedures set forth by the U.S. Environmental Protection Agency (USEPA) for the assessment and restoration of former disposal and spill sites. The long-range objectives of the IRP at the Fort Leonard Wood Military Reservation (FLWMR) in Missouri are to assess the extent and magnitude of con- 
tamination at selected abandoned waste-disposal sites and, if necessary, conduct remedial efforts to control contaminant releases. During 1994, the Fort Leonard Wood (FLW), Directorate of Public Works, Environmental Division, requested that the U.S. Geological Survey (USGS) conduct a regional geohydrologic and water-quality assessment of the entire FLWMR and perform a general assessment of the quality of water at selected solid-waste management units (SWMU) at the FLWMR (fig. 1). The regional geohydrologic assessment was designed to characterize the geohydrologic framework of the FLWMR and provide the background hydrochemical data necessary to conduct and interpret more detailed assessments of contaminant distribution and movement near individual SWMU sites. The results of the regional geohydrologic assessment have been published (Imes and others, 1996). A short summary document describing the complex karst terrane and associated ground-water flow system at the FLWMR and results of additional dye-trace tests not reported in Imes and others (1996) was prepared by Kleeschulte and Imes (1997).

The assessments at the SWMUs were performed to assist the FLWMR in assessing the contamination potential at the 12 selected sites. Preliminary assessments were conducted during 1995 concurrently with the regional geohydrologic assessment. The study area for reconnaissance appraisal of each SWMU included the immediate vicinity of each site and areas where ground or surface water can readily migrate from the site. During the regional water-quality assessment of the FLWMR, tetrachloroethene (PCE) contamination was detected in Shanghai Spring (fig. 2) northeast of the FLWMR (Imes and others, 1996). Because of the proximity of the old FLWMR laundry and dry cleaning shop (FLW-056) to Shanghai Spring, this site was included in the list of SWMUs to be investigated. The SWMUs investigated were:

$\begin{array}{cl}\text { FLW-002 } & \text { Closed sanitary landfill 2 } \\ \text { FLW-003 } & \text { Closed sanitary landfill 3A } \\ \text { FLW-004 } & \text { Closed sanitary landfill 3B } \\ \text { FLW-005 } & \text { Closed sanitary landfill 3C } \\ \text { FLW-028 } & \text { Old fire training area } \\ \text { FLW-030 } & \begin{array}{c}\text { Range 24 open-burning/open- } \\ \text { detonation area }\end{array} \\ \text { FLW-032 } & \begin{array}{r}\text { Air National Guard Cannon Range } \\ \text { exploded ordnance burial area }\end{array} \\ \text { FLW-037 } & \text { Old pesticide storage building 2206 }\end{array}$

$\begin{array}{ll}\text { FLW-040 } & \text { Ammunition container storage area } \\ \text { FLW-056 } & \text { Old laundry/dry cleaning shop } \\ \text { FLW-059 } & \text { Closed sanitary landfill } \\ \text { FLW-060 } & \text { Closed sanitary landfill }\end{array}$

\section{Purpose and Scope}

This report presents the results of preliminary geohydrologic and water-quality assessments of 12 SWMUs at the FLWMR and a geohydrologic and water-quality assessment of Shanghai Spring. A summary of dye-trace tests conducted at the FLWMR also is presented. Assessments summarized in this report were conducted during a 3-year period from 1995 to 1998. The preliminary assessments of most SWMUs were conducted during 1995 and included the collection and analyses of samples from soil, streambed sediment, seeps, springs, nearby surface-water sources, and existing monitoring wells. Based on results of the preliminary assessment, a detailed characterization of the old pesticide storage building 2206 (FLW-037) was conducted during 1996 (building materials) and 1997 (building foundation, stormwater runoff, and subsurface soil assessment). During 1997, soil borings and soil-gas assessments were conducted at FLW-056 to determine if substantial quantities of solvents were disposed or spilled at this facility. Soil-gas assessments also were conducted at FLW-002 during 1997 and 1998. Five additional monitoring wells were installed at FLW-002 and four temporary monitoring wells were installed at FLW-059 during 1997 to further characterize ground-water quality at these sites.

A continual gaging and water-quality monitoring station was installed at Shanghai Spring during 1997 to monitor changes in water quality with discharge. Because effects from the FLWMR sewage treatment plant (STP) and an unknown source of PCE were detected at Shanghai Spring during the regional assessment of the FLWMR during 1995 (Imes and others, 1996), additional dye-trace tests were conducted during 1996 and 1997 to further characterize the relation between FLW-002 and Shanghai Spring and delineate the recharge basins of several springs in the vicinity of the FLWMR. 


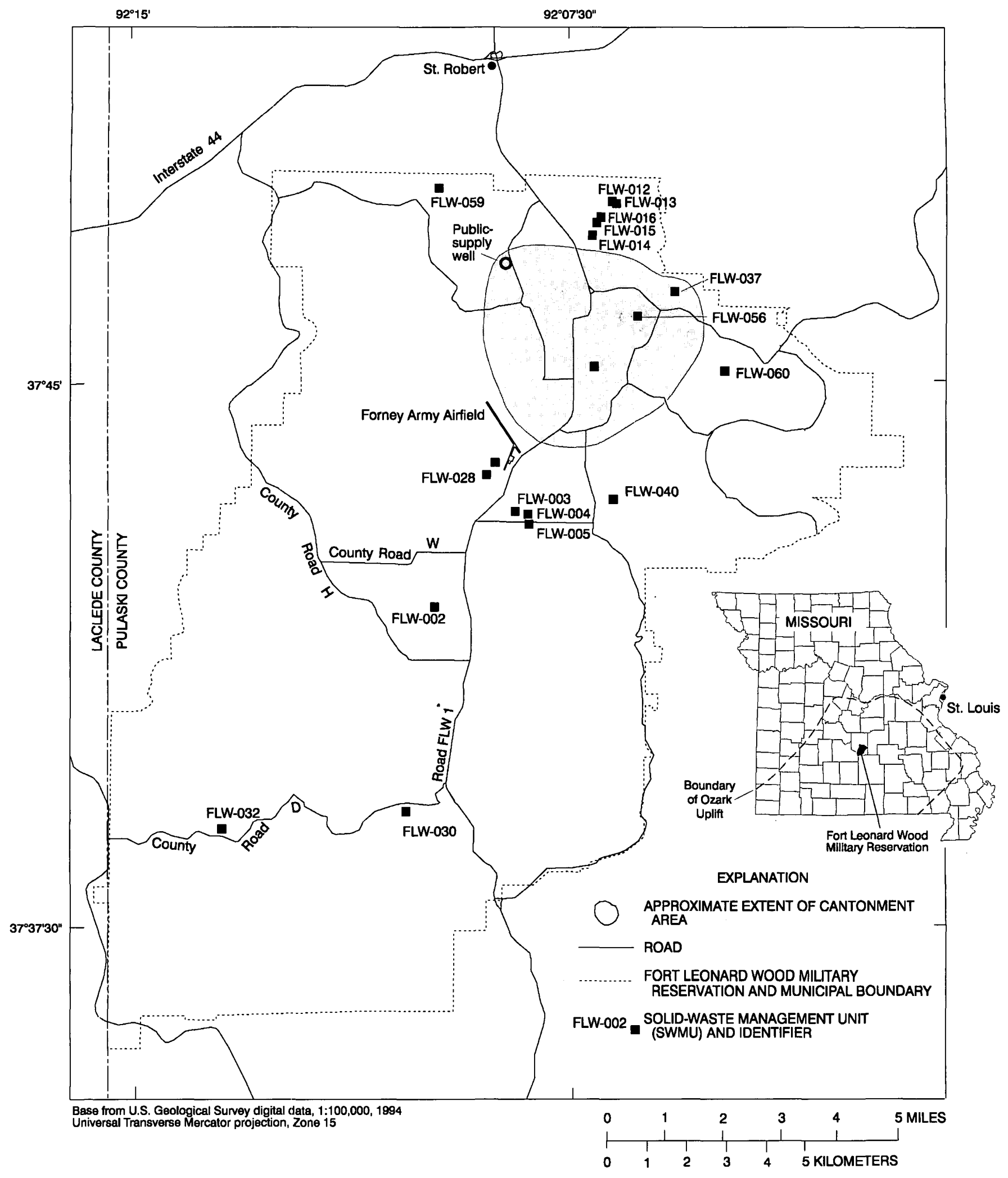

Figure 1. Location of the Fort Leonard Wood Military Reservation and selected solid-waste management units. 


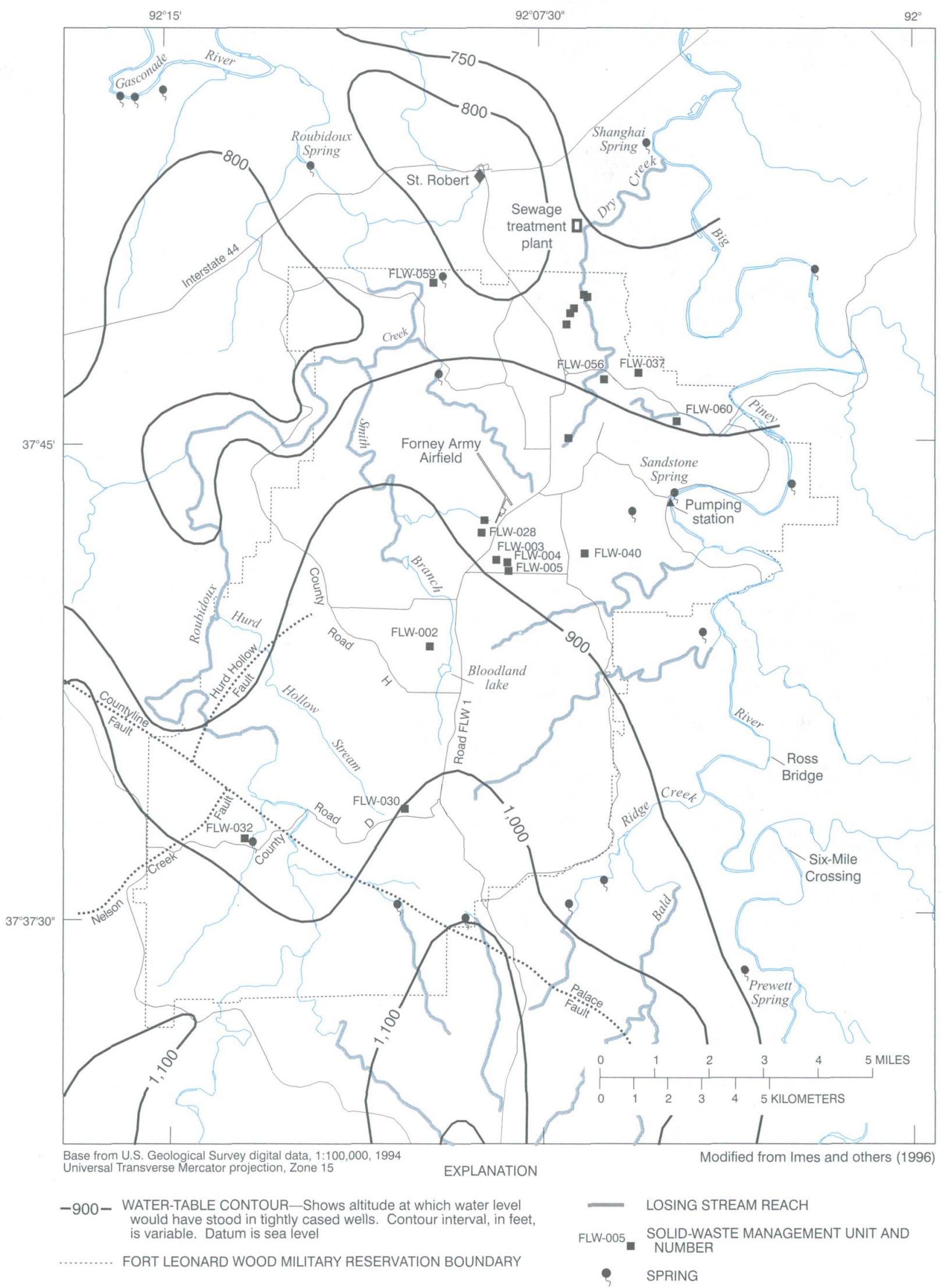

Figure 2. Altitude of the regional water table and location of springs and selected solid-waste management units at the Fort Leonard Wood Military Reservation and vicinity. 


\section{Description of Study Area}

The FLWMR is located in south-central Missouri, almost entirely within Pulaski County (fig. 1), approximately $130 \mathrm{mi}$ (miles) southwest of St. Louis. The primary mission of the FLWMR is combat troop training. The FLWMR consists of approximately 64,000 acres of land, including a small aircraft landing strip, Forney Army Airfield. The FLWMR opened during 1941 for the training of combat troops during World War II. The FLWMR was closed in 1946 at the end of the war, but was re-opened during 1956 as a combat troop training center and engineering school.

Many facilities are concentrated in the cantonment area (fig. 1) that occupies the north-central part of the FLWMR. This area contains classrooms, barracks, recreation and shopping facilities, and support units. The remainder of the FLWMR contains large tracts of land set aside for small arms firing ranges, training areas for armored vehicles night maneuvers, an Air National Guard (ANG) cannon and strafing range, and heavy equipment training areas. During 1995, as part of the Base Realignment and Closure Commission (BRAC), the U.S. Army initiated the relocation of the U.S. Army Chemical and Military Police Schools from Fort McClellan, Alabama, to FLWMR. In 1998, the FLWMR was home to the 1st Engineer Brigade (Center), the 3rd Basic Training Brigade, the 43rd Adjutant General Battalion, and a Military Police Command.

The FLWMR is located within the Salem Plateau of the Ozark Plateaus Physiographic Province (Fenneman, 1938), an area characterized by a rugged terrain of thin soils and narrow steep-walled valleys. Most of the FLWMR is located on a broad central ridge between the northerly flowing Big Piney River to the east and the northerly flowing Roubidoux Creek to the west (fig. 2). Tributary streams to the Big Piney River and Roubidoux Creek drain the upland areas and are deeply incised into the sides of the ridge.

Area relief generally is the result of gradual uplift of the Ozark Uplift in southern Missouri and erosion of the uplifted rocks by rainfall runoff and streamflow. The regional land surface altitude ranges from about $1,150 \mathrm{ft}$ (feet) above sea level along parts of the central ridge to about $750 \mathrm{ft}$ above sea level at the Big Piney River near the northeastern boundary of the FLWMR. Roubidoux Creek is not as deeply incised, nor does it have as large a flow, as the Big Piney River. During most of the year, the reach of Roubidoux Creek from the Hurd Hollow Fault to near FLW-059 in the northwestern part of the FLWMR generally is dry (fig.
2). The altitude of Roubidoux Creek near the northwestern boundary of the FLWMR is about $780 \mathrm{ft}$ above sea level.

\section{Geology}

The FLWMR lies on the western flank of the Ozark Uplift of southern Missouri (fig. 1). The Ozark Uplift dominates the geology of southern Missouri and is part of a large Precambrian rhyolite-granite basement complex that probably formed a continental divide in late Precambrian time (Lidiak and others, 1966; Muehlberger and others, 1967). The core of the Ozark Uplift is located in southeastern Missouri. Through a series of depositional and erosional cycles extending from Cambrian to Pennsylvanian time, progressively younger geologic formations crop out in approximately concentric rings around the core of Precambrian rocks. Rocks of Early Ordovician age are exposed at the FLWMR, which is located on the northern flank of the regional surface-water divide across southern Missouri (McCracken, 1971). Ordovician rocks exposed at the FLWMR are, in order of decreasing age, the Gasconade Dolomite, Roubidoux Formation, and the Jefferson City Dolomite.

Detailed geologic mapping of the FLWMR focusing on bedrock fractures, faults, and geologic contacts was conducted by Harrison and others (1996). Results of this effort indicated that strata at the FLWMR are essentially horizontal with dips of 1.5 degrees or less. Dips greater than 2 degrees are associated with localized sedimentary features such as bioherms and solution-collapse features. Three near vertically dipping faults (Countyline Fault, Nelson Creek Fault, and Hurd Hollow Fault) with vertical displacements of less than $100 \mathrm{ft}$ were also identified in the south and western parts of the FLWMR (fig. 2).

The Gasconade Dolomite predominantly is a cherty dolostone and commonly is exposed as bluffs along the Big Piney River and Roubidoux Creek valleys (fig. 3). The unit is about $300 \mathrm{ft}$ thick and can be separated into an upper and lower part based on the amount of chert and bedding characteristics (Harrison and others, 1996). The lower part is about $250 \mathrm{ft}$ thick, contains moderate to abundant chert, and is medium to thinly bedded. The upper part is about 30 to $50 \mathrm{ft}$ thick, is nearly chert free, and is more massive to thickly bedded. The upper part contains intraformational breccia horizons as much as $4 \mathrm{ft}$ thick that may be indicative of larger permeability zones that are capable of transmit- 


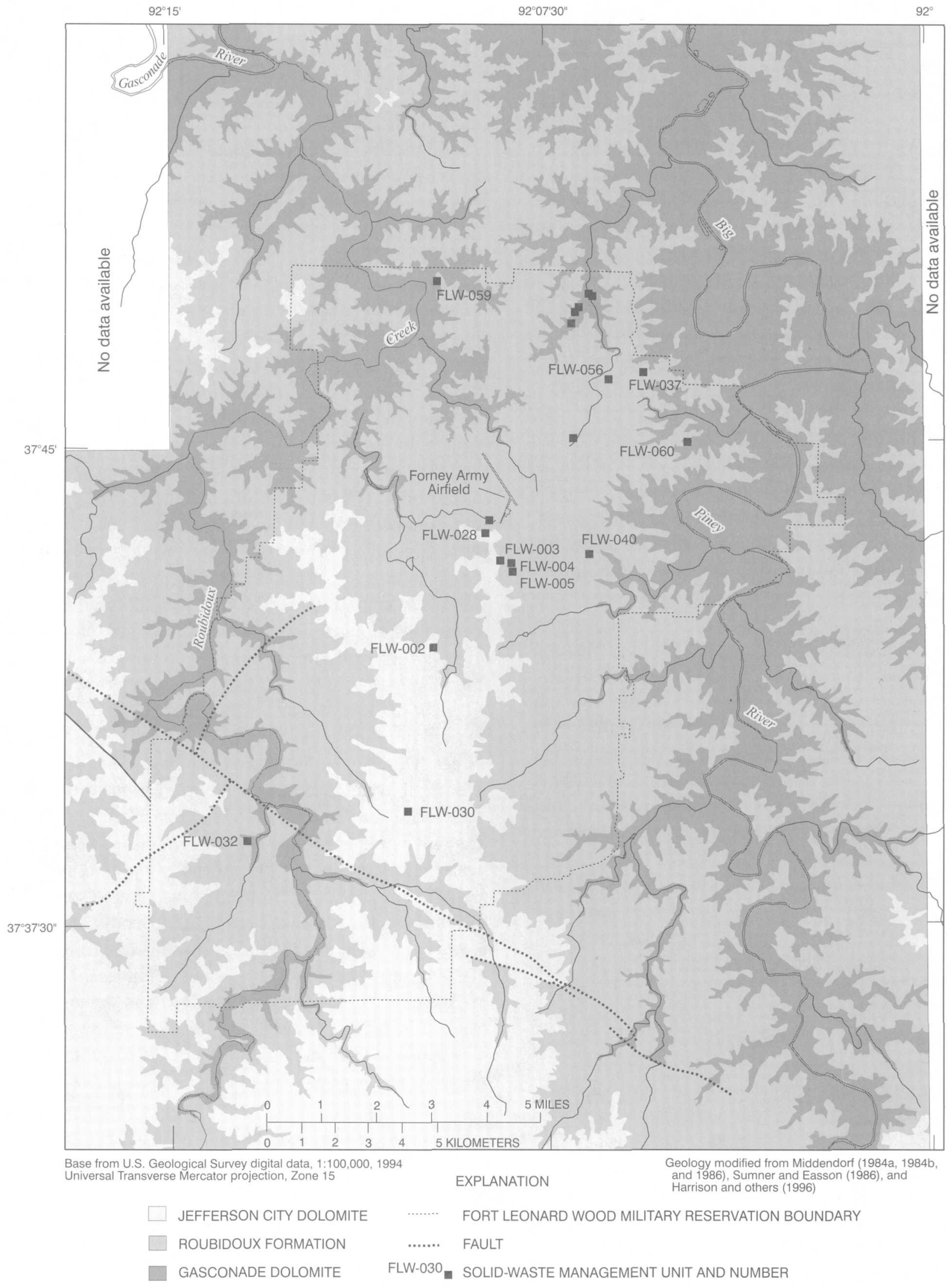

Figure 3. Bedrock geologic formations at the Fort Leonard Wood Military Reservation and vicinity. 
ting large quantities of water. Most caves and larger springs at the FLWMR and vicinity occur in the upper part of the Gasconade Dolomite.

The overlying Roubidoux Formation ranges in composition from nearly pure quartzose sandstone to dolomitic sandstone and cherty dolostone. The Roubidoux Formation crops out across most of the upland areas and hillsides in the western, northern, and eastern parts of the FLWMR (fig. 3). Harrison and others (1996) noted substantial dissolution of the more dolomitic parts of the lower Roubidoux Formation, resulting in the subsequent collapse of the overlying, more sandstone-rich beds. This intense dissolution of the lower part of the formation is expressed as a pattern of narrow steep-sided folds in the overlying sandstone units. Most sinkholes occurring in upland areas of the FLWMR are formed in the Roubidoux Formation.

The Jefferson City Dolomite crops out extensively in upland areas in the southern part of the FLWMR (fig. 3) where the unit is as much as $180 \mathrm{ft}$ thick. The formation typically is finely crystalline argillaceous dolostone that contains shale partings and brecciated chert. A massive bed of gray, finely crystalline argillaceous dolostone informally referred to as the Quarry Ledge by Thompson (1991), because of its resistance to erosion, occurs about $30 \mathrm{ft}$ above the base of the formation throughout the FLWMR (Harrison and others, 1996). A variable thickness of residuum consisting of clayey chert to cherty clay is present across upland areas of the FLWMR. Locally, clay-rich deposits are associated with collapse features such as filled sinkholes.

A variable thickness of alluvium is present along the Big Piney River and Roubidoux Creek. The alluvium consists of sorted and unsorted sands, silt, gravel, and clay and generally are less than $30 \mathrm{ft}$ thick.

\section{Ground-Water Hydrology}

Ground-water supplies at the FLWMR and vicinity are from wells that are completed in the Ozark aquifer, the middle aquifer of the Ozark Plateaus aquifer system (Imes and Emmett, 1994). Across southern Missouri, the Ozark aquifer is used extensively for domestic and public supply. Although the Ozark aquifer includes the Jefferson City Dolomite, this formation generally is unsaturated at the FLWMR, and the regional water table generally occurs within the lower Roubidoux Formation or upper Gasconade Dolomite. The Roubidoux Formation and Gasconade Dolomite are productive water-bearing strata with well yields ranging from several tens to several hundreds of gallons per minute (Melton, 1976). Unlike most of the municipalities in southern Missouri, which generally obtain their water from ground-water sources, the FLWMR obtains nearly all of its drinking water from a pumping station on the Big Piney River (fig. 2). A public-supply well is in the northern part of the FLWMR, but is used only during peak demand (fig. 1). Several small capacity (less than a few tens of gallons per minute) wells supply drinking water to training facilities that are scattered across the FLWMR.

Recharge to the ground water at the FLWMR occurs by percolation of rainfall through permeable residuum and bedrock. Ground-water flow in the aquifer mainly is controlled by regional topography, but local anomalies on the regional flow system are produced by flow through solution-enlarged openings in the karst bedrock. Although numerous fractures occur throughout the bedrock units, most of these are closed or not through-going, and most discrete ground-water flow is thought to occur through secondary porosity developed along bedding planes (Imes and others, 1996). A north-trending ground-water divide occurs in the FLWMR with ground water generally flowing away from the uplands along the axis of this divide east toward the Big Piney River or west toward Roubidoux Creek (fig. 2). Depths to the water table at the FLWMR are variable and generally range from about 130 to 300 $\mathrm{ft}$ or more in upland areas to less than $25 \mathrm{ft}$ in the Big Piney River or Roubidoux Creek valleys. The higher water levels in the upland areas are supported by the percolation of rainwater through unsaturated soil and residuum in these areas. The rate of ground-water flow away from the upland recharge areas is determined by the bedrock permeability. Where differences in vertical permeability of various materials exist in the unsaturated zone, isolated saturated zones or perched water tables may occur. Flow in these perched water tables is variable and may not follow regional ground-water flow patterns.

Karst features commonly are well developed at the FLWMR, and numerous caves, springs, and more than 220 sinkholes have been identified at the FLWMR (fig. 4). The number of sinkholes identified is limited by the resolution of aerial photography used in the inventory and may, in fact, be much larger. The presence of karst features can substantially alter the movement of ground water from flow patterns commonly associated with rocks of more uniform permeability. 


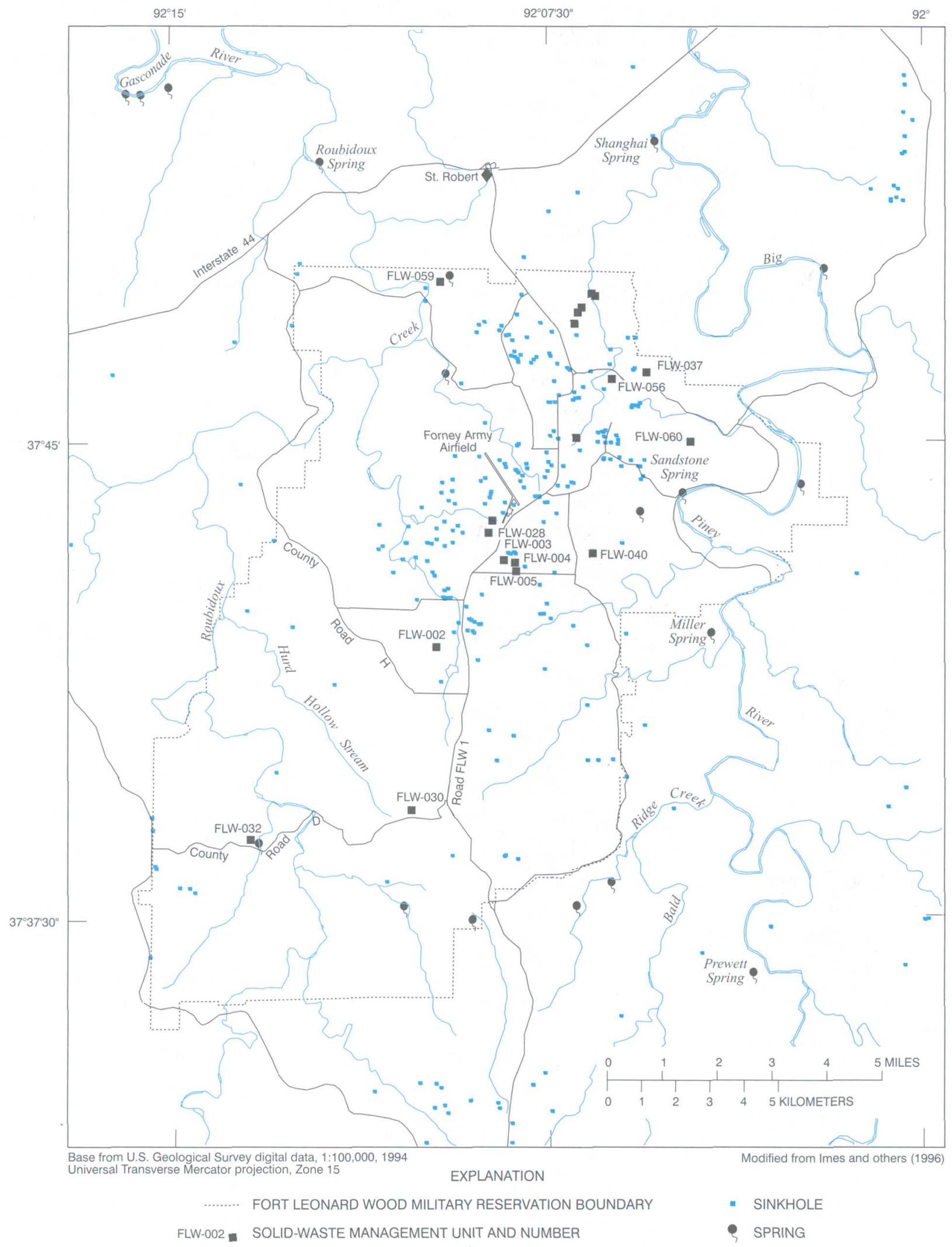

Figure 4. Location of sinkholes, springs, and selected solid-waste management units at the Fort Leonard Wood Military Reservation and vicinity. 
For example, in the central part of the FLWMR the ground-water divide is as much as $2 \mathrm{mi}$ west of the topographic divide. The large lateral separation between the ground-water and topographic divides indicates a substantially larger bedrock permeability in the east-central part of the FLWMR (Imes and others, 1996). In this area, ground water that normally would have flowed westward to Roubidoux Creek has been captured by a zone of large secondary permeability and redirected eastward toward the Big Piney River.

Ground-water flow patterns at the FLWMR are the result of a complex combination of diffuse flow through porous residual material and bedrock and conduit flow through solution-enlarged openings along bedding planes and interconnected fractures. A number of dye-trace tests have previously been conducted at the FLWMR to determine spring catchment areas (Harvey, 1980; Rory McCarthy, Fort Leonard Wood Military Reservation, written commun., 1995; Imes and others, 1996). Dye that was injected into sinkholes or losing stream segments at the FLWMR emerged at one of four known perennial springs-Miller Spring, Roubidoux Spring, Shanghai Spring, or Sandstone Spring (fig. 5). Sandstone Spring previously was referred to by Imes and others (1996) as the "pumping station spring" and is the only one of the four springs located on the FLWMR.

Ground-water quality at the FLWMR typically is good with dissolved solids (DS) concentrations generally less than $300 \mathrm{mg} / \mathrm{L}$ (milligrams per liter), and calcium $(\mathrm{Ca})$, magnesium $(\mathrm{Mg})$, and bicarbonate $\left(\mathrm{HCO}_{3}\right)$ as the predominant ions (Imes and others, 1996).

Although of generally good quality, ground water at the FLWMR and vicinity is vulnerable to contamination from surficial sources. During the regional water-quality assessment of the FLWMR and vicinity, Imes and others (1996) identified several wells that were affected by human or animal wastes or nitrogen-containing fertilizers. Several wells also contained small (less than a few micrograms per liter) concentrations of volatile organic compounds (VOCs) or pesticides (diazinon, DDE, tebuthiuron). The presence of contaminants in several wells combined with the travel times obtained from successful dye-trace tests at the FLWMR indicates that contaminants from the FLWMR could be transported to vicinity springs within a matter of days.

\section{Surface-Water Hydrology}

Surface-water drainage within the FLWMR is by small tributary streams and dry washes that direct water from a topographic ridge that divides the eastern and western parts of the FLWMR. Drainage systems in the eastern one-half of the FLWMR discharge water into the Big Piney River, which flows northward near the eastern boundary of the FLWMR and discharges water into the Gasconade River. Drainage systems in the western one-half of the FLWMR discharge water into Roubidoux Creek, which flows northward near the western boundary of the FLWMR and discharges water into the Gasconade River. Most of the several manmade ponds and lakes that have been built on the FLWMR are near the topographic ridge south of Forney Army Airfield. Most of these impoundments were constructed in the headwater areas of small ephemeral streams. At least one lake was built over an active sinkhole that subsequently collapsed.

A series of stream-discharge measurements on the Big Piney River and Roubidoux Creek made during the regional geohydrologic assessment indicate markedly different base-flow characteristics between these two streams (Imes and others, 1996). Although discharge of the Big Piney River increases with increasing distance downstream in the vicinity of the FLWMR, most of the increase in flow can be attributed to inflow from tributaries and springs with little flow being lost or gained through diffuse flow through the streambed. When the effect of tributary and spring inflow is removed, Imes and others (1996) concluded that the Big Piney River loses flow (to the ground-water system) along a 6-mi reach upstream from the FLWMR between Six-Mile Crossing and Ross Bridge (fig. 2), gains flow along a 12-mi reach between Ross Bridge and a point where the river leaves the FLWMR boundary, and then loses a slight amount of flow along the reach downstream from the FLWMR. During a series of stream-discharge measurements in September 1995, discharge of the Big Piney River in the vicinity of the FLWMR was between about 170 and $190 \mathrm{ft}^{3} / \mathrm{s}$ (cubic feet per second) (Imes and others, 1996). In contrast to the subtle changes in base flow along the Big Piney River, base flow along Roubidoux Creek fluctuates dramatically in the vicinity of the FLWMR. Roubidoux Creek gains a slight amount of flow through its streambed upstream from the FLWMR and along about a 7-mi reach in the southwestern part of the FLWMR. However, along a relatively short reach ( 2 to $3 \mathrm{mi}$ ) in the southwestern part of the FLWMR, Imes and others 


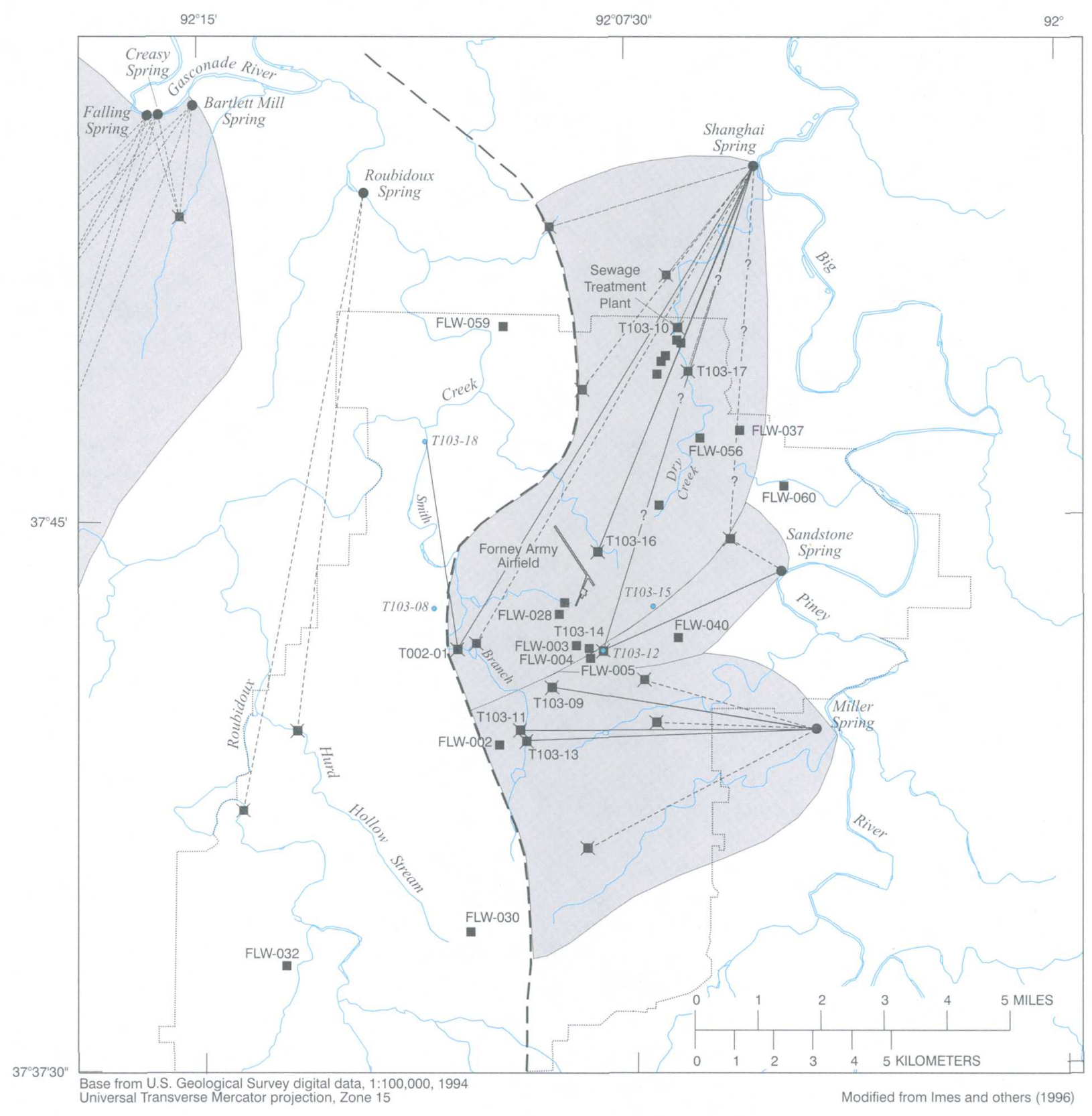

EXPLANATION

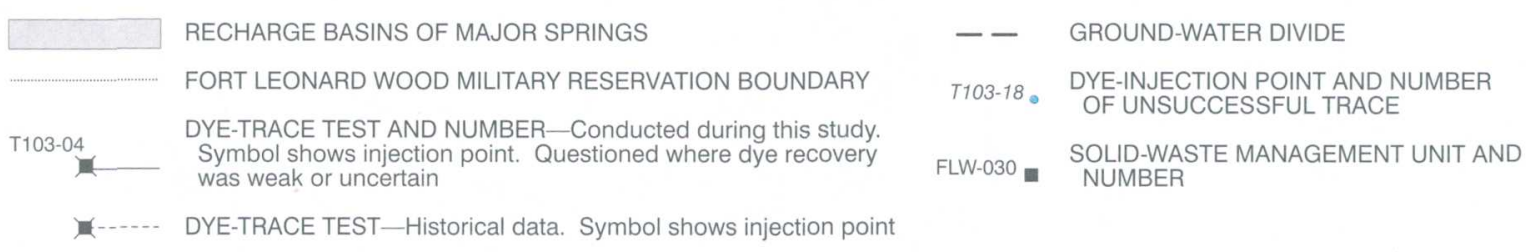

Figure 5. Recharge basins of major springs and injection and recovery points for dye-trace tests in and near the Fort Leonard Wood Military Reservation and vicinity. 
(1996) noted the entire flow of Roubidoux Creek was lost during high-base flow (about $40 \mathrm{ft}^{3} / \mathrm{s}$ ) and lowbase flow (about $7 \mathrm{ft}^{3} / \mathrm{s}$ ) conditions. The reach where most flow loss occurs is in the area of the intersections of Roubidoux Creek, the Countyline Fault, and Hurd Hollow Fault (Harrison and others, 1996). Except during high-flow conditions caused by large amounts of runoff, a 7- to 8-mi reach of Roubidoux Creek along the western boundary of the FLWMR is dry. Typically flow resumes in Roubidoux Creek near FLW-059 about $1 \mathrm{mi}$ before the stream channel crosses the northern boundary of the FLWMR (fig. 2).

\section{Previous Assessments}

More than 25 environmental assessments have been conducted at the FLWMR by various agencies since the mid-1970's. These assessments included general evaluations of geology, air and water quality, the FLWMR waste-water treatment system, and numerous site specific assessments of training facilities, industrial operations, and selected SWMUs. An initial installation assessment of the FLWMR was conducted by the U.S. Army Environmental Hygiene Agency (USAEHA) in 1982 (Environmental Science and Engineering, 1982). This assessment was done to determine if toxic-or hazardous-materials contaminants existed at the FLWMR, which had the potential to migrate off the FLWMR. The assessment summarized ground and surface water-quality data collected during several previous USAEHA site visits to the FLWMR between 1976 and 1982 and included an extensive literature search for environmental data for the FLWMR. The report concluded that waste solvents were being disposed in FLW-002 in violation of State of Missouri solid-waste regulations in effect at that time and that pesticides in soils adjacent to the old pesticide storage building (FLW-037) may present an environmental hazard because of their large DDT concentration. The report also identified leachate seeps and erosion concerns at several solid-waste landfills and open dumping of household wastes at the FLWMR.

Subsequent to the initial installation assessment, several general assessments of SWMU at the FLWMR were conducted in the late 1980's and early 1990's by the USAEHA and FLWMR contractors. The objectives of these assessments were to conduct a limited environmental sampling program to identify the release of hazardous wastes from the SWMUs. During 1987 and 1988 , the USAEHA conducted an assessment of the environmental effect of FLW-002, FLW-003, FLW004, and FLW-005 on ground water (U.S. Army Environmental Hygiene Agency, 1988a). Seventeen shallow monitoring wells were drilled into the residuum at these SWMUs to collect ground-water samples. Depth to the water table in the upland area commonly exceeds $100 \mathrm{ft}$, which accounts for the observation that all 17 wells were dry in the fall and only 4 contained sufficient water to sample during the spring. The sampled water probably was water temporarily perched above less permeable sediments. One leachate sample also was collected. The report concluded that there was no adverse ground-water effect in the unconsolidated deposits; however, two of four samples had increased levels of sodium ( $\mathrm{Na}$ ) (28 to $102 \mathrm{mg} / \mathrm{L}$ ) and chloride (Cl) (37 to $97 \mathrm{mg} / \mathrm{L}$ ), indicating effects from landfill leachate.

During a follow-up assessment of FLW-002, FLW-003, FLW-004, and FLW-005 and several other sites, additional monitoring wells were installed into the shallow bedrock (U.S. Army Environmental Hygiene Agency, 1990). Most of these monitoring wells also were dry, and the report concluded that deeper monitoring wells were needed to determine if hazardous constituents have been released from these sites. The final Resource Conservation and Recovery Act (RCRA) Facility Assessment Report (PRC Environmental Management, Inc., 1992) for the FLWMR summarized data for 54 SWMUs and concluded that because of the paucity of data and potential existence of hazardous constituents, FLW-002, FLW-028, FLW030, FLW-032, FLW-037, and FLW-040 warranted additional environmental assessments. No monitoring well drilling or water sampling was conducted during this study.

Although several general assessments of selected SWMU have been done, none of the previous studies have focused on understanding the regional ground- and surface-water hydrology of the FLWMR or the geohydrologic setting of the SWMUs in relation to the regional hydrology. A summary of the types of matrices sampled and analyses performed on environmental samples previously collected from the 12 SWMUs of interest to this assessment is listed in table 1. 
Table 1. Summary of types of matrices sampled and analyses performed during previous assessments of selected solidwaste management units at the Fort Leonard Wood Military Reservation

[Ma, major ions; Nu, nutrients; Tr, trace elements; SVs, semi-volatile organic compounds; VOCs, volatile organic compounds; Pe, pesticides; PCBs, polychlorinated biphenyls; TPH, total petroleum hydrocarbons; Ex, explosives]

\begin{tabular}{|c|c|c|c|c|c|c|c|c|}
\hline $\begin{array}{c}\text { Solld-waste } \\
\text { management } \\
\text { unit }\end{array}$ & $\begin{array}{c}\text { Visual } \\
\text { Inspectlon }\end{array}$ & $\begin{array}{c}\text { Aerial } \\
\text { photography } \\
\text { revlew }\end{array}$ & $\begin{array}{l}\text { Surface } \\
\text { soil } \\
\text { samples }\end{array}$ & $\begin{array}{c}\text { Subsurface } \\
\text { soil } \\
\text { samples }\end{array}$ & $\begin{array}{c}\text { Surface- } \\
\text { water } \\
\text { sampling }\end{array}$ & $\begin{array}{l}\text { Seep and } \\
\text { spring } \\
\text { sampling }\end{array}$ & $\begin{array}{l}\text { Streambed } \\
\text { sediment } \\
\text { sampling }\end{array}$ & $\begin{array}{l}\text { Monitoring well } \\
\text { installation and } \\
\text { sampling }\end{array}$ \\
\hline FLW-002 & Yes & No & No & No & No & $\begin{array}{c}1988 \\
\text { (Ma, Nu, Tr, SVs, } \\
\text { VOCs, Pe, PCBs) }\end{array}$ & No & $\begin{array}{c}1987,1990 \\
\text { (Ma, Nu, Tr, SVs, } \\
\text { VOCs, Pe, PCBs) }\end{array}$ \\
\hline FLW-003 & Yes & No & No & No & No & No & No & $\begin{array}{c}1987,1990 \\
\text { (Ma, Nu, Tr, SVs, } \\
\text { VOCs, Pe, PCBs) }\end{array}$ \\
\hline FLW-004 & Yes & No & No & No & No & No & No & $\begin{array}{c}1987,1990 \\
\text { (no data) }\end{array}$ \\
\hline FLW-005 & Yes & No & No & No & No & No & No & $\begin{array}{c}1987,1990 \\
\text { (Ma, Nu, Tr, SVs, } \\
\text { VOCs, Pe, PCBs) }\end{array}$ \\
\hline FLW-028 & Yes & No & No & $\begin{array}{c}1990 \\
(\mathrm{Tr}, \mathrm{SVs} \\
\text { VOCs, TPH) }\end{array}$ & No & No & No & No \\
\hline FLW-030 & Yes & No & No & No & No & No & No & No \\
\hline FLW-032 & Yes & No & $\begin{array}{c}1990 \\
(\mathrm{Tr}, \mathrm{Ex})\end{array}$ & No & No & No & No & No \\
\hline FLW- $037^{\mathrm{a}}$ & Yes & No & $\begin{array}{l}1990 \\
(\mathrm{Pe})\end{array}$ & No & No & No & No & No \\
\hline FLW- $040^{\circ}$ & Yes & No & No & No & No & No & No & No \\
\hline FLW-056 & No & No & No & No & No & No & No & No \\
\hline FLW-059 & Yes & No & No & No & No & No & No & No \\
\hline FLW-060 & Yes & No & No & No & No & No & No & No \\
\hline
\end{tabular}

${ }^{a}$ Wipe samples from surfaces of interior walls and floors were analyzed for organochlorine pesticides.

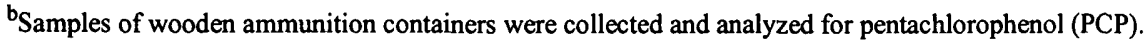

Imes and others (1996) concluded that water samples from Shanghai Spring contained larger-thanbackground concentrations of chemicals commonly associated with septic contamination, such as dissolved and total sodium $\left(\mathrm{Na}\right.$ and $\mathrm{Na}_{\mathrm{t}}$ ), dissolved chloride $(\mathrm{Cl})$, total nitrite plus nitrate $\left(\mathrm{NO}_{2 \mathrm{t}}+\mathrm{NO}_{3 \mathrm{t}}\right)$, total phosphorous $\left(\mathrm{P}_{t}\right)$, dissolved and total boron $\left(\mathrm{B}\right.$ and $\left.\mathrm{B}_{t}\right)$, dissolved sulfate $\left(\mathrm{SO}_{4}\right)$, and total ammonia $\left(\mathrm{NH}_{3 t}\right)$. Concentrations of inorganic chemical constituents and pesticides in water samples referenced in this report are dissolved unless noted otherwise. Dye-trace tests have confirmed the presence of a direct subsurface connection between Shanghai Spring and the point where treated effluent from the FLWMR STP is discharged into Dry Creek (fig. 5). Imes and others (1996) determined that the increased concentrations of inorganic constituents in Shanghai Spring were caused by effluent discharge. Water discharging from Shanghai Spring also contained detectable concentrations of PCE and trace concentrations of the pesticides prometon and simazine.

\section{METHODS OF ASSESSMENT}

Assessments of selected SWMUs at the FLWMR generally were conducted in three phases. Phases I and II comprised a preliminary assessment of each site. The first phase included an information search, including a review of historical aerial photographs, an initial site visit, and, in some cases, interviews with former employees. The second phase involved a reconnaissance of each site noting the general appearance of the site and the existence of obvious signs of disturbance such as excavations, debris, stressed vegetation, or unusual topography. The location and discharge of seeps, springs, or nearby streams also were noted and, in some cases, preliminary measurements of specific 
conductance or the collection and analysis of water samples for VOC analyses using a portable gas chromatograph (GC) were done. Subsequent site visits were made to collect environmental samples from each site. The number and type of environmental samples collected and the suite of chemical constituents analyzed in the samples were dependent on the types of activities conducted at each site. In general, samples were collected from surficial soils, streambed sediments, existing monitoring wells, seeps, and nearby streams at each site. A summary of the types of samples collected from each SWMU is listed in table 2, at the back of this report. Other onsite activities included the sampling of building materials at FLW-037 and soil-gas sampling at FLW-002 and FLW-056. Based on the results of the phase I and phase II activities, work plans for additional characterization of FLW-002, FLW-003, FLW005, FLW-037, and FLW-059 were prepared and additional characterization of these sites was initiated as phase III. The following is a generalized discussion of the procedures used in the collection of environmental samples for this assessment.

\section{Soil and Streambed Sediment Sampling and Analysis}

Composite surface soil (hereinafter referred to as soil) samples (less than $1 \mathrm{ft}$ deep) were collected from all SWMUs except those that potentially contained unexploded ordnance (UXO) (FLW-030 and FLW-032) using a stainless steel hand auger or pick. A rectangular grid was surveyed across each site, and between 20 and 30 subsamples were collected at the grid points.

Because the principal area of interest at FLW-040 was a concrete pad used for the storage of ammunition containers, soil samples were collected around the perimeter of the pad. After collection, the subsamples [0.5 to $1 \mathrm{~kg}$ (kilogram) each] were placed in sealed plastic bags and shipped to the USGS geochemistry laboratory in Denver, Colorado, for compositing and analysis. On receipt at the laboratory, the subsamples were combined, air dried, disaggregated with a jaw crusher, and split using a Jones splitter into two equal-size containers. Split 1 was used for the determination of grain-size and preliminary chemical analysis of the less-than$0.063-\mathrm{mm}$ (millimeter) size fraction (referred to as the fine fraction) by argon-plasma emission spectroscopy followed by inductively coupled argon plasma (ICP) analysis. Split 2 was pulverized to less, than $0.125 \mathrm{~mm}$ for the determination of bulk mineralogy by X-ray dif- fraction (XRD), optical mineralogy, and carbon content. If the preliminary emission spectroscopy analysis of split 1 detected unusually large concentrations of trace elements such as copper $(\mathrm{Cu})$, lead $(\mathrm{Pb})$, or zinc ( $\mathrm{Zn})$ compared to values in Missouri soils (Tidball, 1984), a sample of the nonmagnetic heavy-mineral fraction was analyzed by optical mineralogic techniques and grain-specific XRD in an attempt to identify the source of the elevated trace element concentrations. Analytical determinations of grain size, mineralogy, carbon contents, and concentrations of inorganic chemical constituents were determined using procedures described in Schumacher and others (1993).

All sampling tools were cleaned between each use. The general cleaning protocol included an initial rinse with a non-phosphate detergent, followed by successive rinses in tap water, dilute acid, deionized water, methanol (organic-compound sampling only), and organic-free deionized water (organic-compound sampling only).

Samples were collected from FLW-028 (composite soil samples) and FLW-040 (subsurface core samples) and submitted to a USGS contract laboratory for the determination of semi-volatile organic compounds (SVs) by USEPA method 8270 (U.S. Environmental Protection Agency, 1984). Subsurface soil samples were collected from FLW-028 using a tractormounted drill rig and 3-in. (inch)-diameter stainless steel push core tube. Because of the rocky soils, soil subsamples were collected from FLW-040 using a methanol-rinsed stainless steel pick and spade. These subsamples were homogenized in a stainless steel pan, composited into a glass jar, and chilled to $4{ }^{\circ} \mathrm{C}$ (degrees Celsius) for overnight shipment to the laboratory.

Subsurface soil samples from FLW-028, FLW037, and FLW-056 were also analyzed onsite for the presence of volatile chlorinated solvents and benzene, toluene, ethylbenzene, and xylene (BTEX) using a portable GC. The portable GC was used to delineate areas of contaminated soil and aid in the selection of samples submitted for laboratory analyses. A 5-cc (cubic centimeter) polyethylene syringe (end removed) was used to remove a subsample from each soil core. The subsample was placed in a $40-\mathrm{mL}$ (milliliters) vial with $20 \mathrm{~mL}$ of organic-free deionized water and sealed with a Teflon-lined septum cap. The vial was vigorously shaken for 2 minutes, inverted, and placed in a heater block $\left(40^{\circ} \mathrm{C}\right)$ for 20 minutes. The head space in the vial was sampled using a $250-\mu \mathrm{L}$ (microliter) gas-tight syringe and immediately injected into the portable GC. 
The portable GC was equipped with a photoionization detector (PID) and a 30-m (meter) Cipsil-5 capillary column in an isothermal oven at $40^{\circ} \mathrm{C}$. The portable GC was calibrated daily using standards prepared by the USGS water-quality laboratory in Arvada, Colorado. Check standards were run every 2 hours of operation and blanks were run after every 5 unknowns.

Because rocky soils at FLW-037 and FLW-056 prevented the use of the push-core sampler, soil samples for portable GC analysis were collected from the bit on a 3-in. outside diameter (OD) solid-stem auger. Hereinafter, concentrations of VOCs determined by the portable GC will be referred to as "field determined" to differentiate them from traditional laboratory analyses.

Soil-gas samples were obtained by installing a 0.75-in. inside diameter (ID) polyvinyl chloride (PVC) tube between 2 and $3 \mathrm{ft}$ below the land surface inside a 3 -in. ID borehole. The bottom of the tube was filled with analytical grade glass wool and covered with an outer aluminum screen to prevent fine particles from entering the tube. The base of the tube was placed within a 1-ft-thick filter pack composed of 10-20 mesh sand. The top of the filter sand was covered with 1 in. of bentonite powder, and the remaining annulus to the land surface was filled with a bentonite grout slurry. The top of the sampler tube was capped with a polyethylene tube attached to a " $T$ " 'splitter and compression clamp. One side of the "T" splitter was used as a sampling port that consisted of a threaded hard polyethylene and Teflon-lined septum cap. The other side of the "T" splitter was used as a vacuum port to which a flexible hose was attached. Soil-gas samples were collected by first applying a vacuum of about $70 \mathrm{cb}$ (centibars) to the sampler using a hand-operated vacuum pump and allowing the vacuum to dissipate. After the vacuum had dissipated, a $250-\mu \mathrm{L}$ gas-tight syringe was inserted through the septum, and a specified volume of gas was withdrawn and injected directly into a portable GC. Several split soil-gas samples also were collected for laboratory confirmation of the portable GC results. The split samples were collected by replacing the " $T$ " fitting from the sampler tube with a Teflon hose and stainless steel compression fitting. The Teflon tubing was attached to a glass adsorption cartridge tube containing an adsorbent media. The outlet side of the adsorption cartridge was connected to a metering pump, and air was pulled through the adsorption cartridge at a rate of $25 \mathrm{~mL} / \mathrm{min}$ (milliliters per minute). Depending on the anticipated concentrations in the soil-gas samples, between 125 and $500 \mathrm{~mL}$ of soil gas was pulled through the adsorption cartridge. After sampling, the cartridges were placed in sealed glass tubes, chilled to $4{ }^{\circ} \mathrm{C}$, and shipped overnight to the Oregon Graduate Institute in Beaverton, Oregon, for analysis by gas chromatography-mass spectrometry (GC-MS).

Composite streambed sediment samples were collected from stream channels likely to receive runoff from each of the SWMUs investigated and submitted for laboratory determination of grain size, concentrations of inorganic constituents, and selected pesticides. The streams adjacent to or potentially receiving runoff from the SWMUs that were investigated during this study generally were small and dry. Subsamples of streambed sediment were collected from the top 4 in. of the streambed using a plastic scoop. Between 20 and 30 subsamples [about $100 \mathrm{~g}$ (grams) each] were collected at random locations along a $100-\mathrm{ft}$ reach of the stream channel and placed into a stainless steel pan. Rocks and debris greater than $2 \mathrm{~cm}$ (centimeter) in diameter were removed before the subsamples were homogenized and placed into a wide-mouth polyethylene jar for shipment to the USGS geochemistry laboratory (analysis of grain size, mineralogy, and inorganic chemical constituents) or a glass jar and chilled to $4^{\circ} \mathrm{C}$ for overnight shipment to the USGS water-quality laboratory in Arvada, Colorado (analysis of organic constituents). The determination of grain size, bulk mineralogy, optical mineralogy, and concentrations of inorganic chemical constituents were performed according to the same procedures as those used for soil samples described previously.

To facilitate comparison of the relative degree of anthropogenic contamination of soil and streambed sediments at each SWMU, concentrations of inorganic constituents in soil or sediment samples from each SWMU were compared to background concentrations for each constituent. However, because of the wide variety of troop training and industrial activities that have occurred throughout the FLWMR since the 1940 's, the identification of background areas known to be free of anthropogenic contamination was impossible. In the absence of samples from areas known to be free of anthropogenic contamination, background concentrations of inorganic constituents were estimated from the samples collected at the SWMUs and compared to published data from a regional geochemical survey of Missouri soils (Tidball, 1984). Estimates of the background concentrations of inorganic constituents in soil and streambed sediment samples were derived by grouping all soil or streambed sediment samples into their respective groups and calculating the 
mean, median, and 95th percentile value for each constituent. If large differences existed between the mean and median values, the data set was reviewed subjectively for outliers (values being several times the magnitude of most values). The outliers (less than 10 total values) were removed and the summary statistics recalculated. The upper limit of background for inorganic constituents was arbitrarily defined as the 95 th percentile of each constituent in the revised data set. Because of the small number of outliers, these estimated background concentrations are considered reasonable.

The estimated background concentrations for $\mathrm{Pb}$ [55 mg/kg (milligrams per kilogram); range of concentrations was 13 to $66 \mathrm{mg} / \mathrm{kg}$ ] and $\mathrm{Zn}(87 \mathrm{mg} / \mathrm{kg}$; range was 33 to $96 \mathrm{mg} / \mathrm{kg}$ ) in soil established using the above process are within the range of $\mathrm{Pb}$ (about 9 to 85 $\mathrm{mg} / \mathrm{kg}$ ) and $\mathrm{Zn}$ (about 18 to $220 \mathrm{mg} / \mathrm{kg}$ ) concentrations determined in 10 soil samples from Pulaski County collected during a regional geochemical survey of soils in Missouri (Tidball, 1984). Some differences in methodology exist, however, as Tidball (1984) determined concentrations of inorganic constituents in the lessthan-2-mm size fraction of soils compared to data from this study that were determined by analyses of only the less-than-0.63-mm size fraction. Therefore, it is possible that the estimated background concentrations of constituents, such as aluminum (Al), that tend to concentrate in minerals that are enriched in the finegrained fraction of soils and sediments may be larger than concentrations listed by Tidball (1984).

\section{Water Sampling and Analysis}

Water-quality samples were collected from seeps, springs, monitoring wells, and surface-water sites at or in the vicinity of the SWMUs to determine if contaminants have migrated from these sites and affected nearby ground- and surface-water quality. In addition, because Shanghai Spring drains a substantial part of the FLWMR and contains detectable concentrations of PCE (Imes and others, 1996), water-quality samples also were collected from this spring. Depending on the site, water samples were analyzed for a comprehensive suite of inorganic and organic constituents, including dissolved and total major cations and anions, trace elements, total cyanide $\left(\mathrm{CN}_{t}\right)$, nutrients, total organic carbon (TOC), a suite of more than 70 VOCs, SVs, selected pesticides, chlorophenoxy-acid herbicides, and explosive associated compounds (XACs).
Water-quality samples were collected using modifications of standard USGS methods (Guy and Norman, 1970; Wood, 1976; Shelton, 1994). Leachate seeps generally were sampled by placing a clean 1-L (liter) Teflon bottle immediately downstream from the seep orifice or using a shovel to construct a small pool at the orifice in which the bottle could be immersed. After the bottle was filled, the contents were placed into a 3-L Teflon compositing container. Sample bottles for unfiltered inorganic and organic constituents were filled directly from the compositing container. Bottles for filtered inorganic constituents were filled using a portable peristaltic pump to obtain water from the compositing container through a $0.45-\mu \mathrm{m}$ (micrometer) disposable capsule filter. Samples for the determination of dissolved organic constituents were filtered using a $142-\mathrm{mm}$ diameter, $1.0-\mu \mathrm{m}$ pore-size, baked-glass fiber filter placed in an aluminum filter holder. A fluid metering pump was used as the pressure source and was attached to the filter assembly using corrugated Teflon tubing. Samples for VOC analyses were filled directly from the seep orifice or pool. The specific conductance, $\mathrm{pH}$, and temperature of leachate seeps were measured after the collection of water-quality samples by placing electrodes directly in the seep orifice.

Water-level measurements in monitoring wells were made using an electric tape calibrated in $0.01-\mathrm{ft}$ increments before the collection of water-quality samples. The tape was rinsed with deionized water before each use. The existing shallow residuum and bedrock monitoring wells were sampled using disposable polyethylene bailers. Larger diameter (4-in. ID) bedrock monitoring wells were installed during this assessment and were sampled using a 2-in.-diameter Grundfos rediflow stainless steel submersible pump fitted with a Teflon-lined polyethylene discharge line.

All monitoring wells were purged to remove stagnant water in the well bore and filter pack before sampling. The water levels in wells that were purged and sampled using the submersible pump were continuously monitored and the pumping rate adjusted so that the water level was not drawn below the top of the well screen. A minimum of two well volumes of water was removed before sampling. During purging, specific conductance, water temperature, $\mathrm{pH}$, and dissolved oxygen concentration were monitored in a closed beaker (water-quality samples were not collected until these measurements had stabilized). Stabilization criteria generally were as follows: specific conductance 
(successive measurements within 2 percent), temperature (successive measurements within $0.5^{\circ} \mathrm{C}$ ), $\mathrm{pH}$ (successive measurements within 0.02 unit), and dissolved oxygen (successive measurements within 0.2 $\mathrm{mg} / \mathrm{L}$ ). Samples for the analyses of total inorganic and organic constituents were collected in the appropriate containers by filling directly from the bailer or pump discharge line [pump discharge rate decreased to approximately $1.5 \mathrm{~L} / \mathrm{min}$ (liter per minute)]. Samples for dissolved inorganic constituents from the larger diameter monitoring wells were filtered by placing the disposable capsule filter directly on the pump discharge line. Samples for analyses of dissolved inorganic constituents from the small diameter wells were processed by filling a 3-L Teflon compositing container and were then pumped through the disposable capsule filter using a peristaltic pump. Samples for dissolved organic constituents (pesticides) were collected by first filling a 3-L Teflon compositing container and using the appropriate pump and filter assembly to process the water.

Water-quality samples were collected from small tributaries (discharge less than several cubic feet per second), streams, and springs by immersing a $1-$ or 3-L Teflon compositing container beneath the water surface near the middle of the channel. Sample bottles were filled directly from the compositing container or filtered as described previously. Discharge was measured or estimated at each site according to methods described in Imes and others (1996). Depth-integrated water samples were collected from Shanghai Spring using a hand-held USGS DH-81 isokinetic Teflon sampler according to the methods described in Edwards and Glysson (1988) and Ward and Hair (1990). A minimum of five individual subsamples were collected at equal width intervals along the upstream side of the county road crossing about $50 \mathrm{ft}$ downstream from the spring orifice. Subsamples were composited in a 3-L Teflon container. Samples for analyses of VOCs were collected directly from the spring or stream by filling and capping the bottles beneath the water surface near the center of flow.

All water-quality sampling and support equipment (compositing containers, pump hoses, and filter assemblies) were thoroughly cleaned before each use. The general cleaning protocol included an initial rinse with a non-phosphate detergent, followed by successive rinses in tap water, dilute acid, deionized water, methanol (organic-compound sampling only), and organic-free deionized water (organic-compound sam- pling only). The submersible pump used for sampling monitoring wells was decontaminated after each use by pumping 10 gal (gallons) of tap water followed by $5 \mathrm{gal}$ of deionized water from a clean plastic bucket at land surface. In addition, samplers, pumps, and hoses were pre-rinsed with ambient water before sample collection and processing. The effectiveness of the cleaning procedures was monitored by the use of routine equipment blanks. In addition to equipment blanks, a number of VOC trip blanks (containing organic-free deionized water) were carried to the sampling sites, preserved, and shipped in sample coolers to verify contaminants were not introduced into VOC samples during sample handling or storage.

The specific conductance of water samples was measured using a portable conductance meter with temperature compensation designed to express values in microsiemens per centimeter at $25^{\circ} \mathrm{C}$. The meter was calibrated before each measurement using standards prepared by the USGS water-quality laboratory in Ocala, Florida. Temperature was measured to the nearest $0.1{ }^{\circ} \mathrm{C}$ using a thermistor attached to the conductance meter. The $\mathrm{pH}$ was measured using a portable pH meter calibrated with standard buffers bracketing the expected sample $\mathrm{pH}$ before each measurement. Dissolved oxygen concentrations were determined by colorimetry to the nearest $0.1 \mathrm{mg} / \mathrm{L}$ using a diethylene glycol and rhodazine-D method developed by Chemetrics, Inc. This method was applicable for concentrations of dissolved oxygen ranging from 0.05 to 1.0 $\mathrm{mg} / \mathrm{L}$. An indigo carmine method (Chemetrics Inc.) was used for dissolved oxygen concentrations larger than $1.0 \mathrm{mg} / \mathrm{L}$. Alkalinity was determined on a $25 \mathrm{~mL}$ aliquot by using incremental titration of 0.16 normal (N) standardized sulfuric acid past the carbonate-bicarbonate base inflection point (approximately pH 8.3) and the bicarbonate-carbonic acid inflection point (approximately $\mathrm{pH} 4.5$ ). Concentrations of carbonate $\left(\mathrm{CO}_{3}\right), \mathrm{HCO}_{3}$, and $\mathrm{CO}_{3}$ alkalinity were later computed using a computer program to integrate the rate of $\mathrm{pH}$ change to the equivalence of acid added.

To decrease or prevent the loss of ions or organic compounds from water samples, a variety of sample preservation treatments were used. When possible, filtering and adding chemical preservatives to environmental samples were done inside a specially outfitted vehicle to decrease the potential for contamination by airborne particulates. Samples to be analyzed for dissolved or total major cations and trace elements were acidified to a pH less than 2 using concentrated trace- 
metal-grade nitric acid $\left(\mathrm{HNO}_{3}\right)$. Samples for the determination of $\mathrm{CN}_{\mathrm{t}}$ were preserved using $10 \mathrm{M}$ (molar) sodium hydroxide to a $\mathrm{pH}$ greater than 10 and chilled to $4^{\circ} \mathrm{C}$. $\mathrm{A} \mathrm{HNO}_{3}$-potassium dichromate solution was used to preserve samples for the analyses of total mercury $\left(\mathrm{Hg}_{t}\right)$. Samples for nutrient analysis were acidified to a pH less than 2 using concentrated sulfuric acid $\left(\mathrm{H}_{2} \mathrm{SO}_{4}\right)$ and chilled to $4^{\circ} \mathrm{C}$. A total of four vials were filled for each VOC sample; two vials were preserved with organic-free hydrochloric acid $(\mathrm{HCl})$ and two vials were unacidified. All VOC vials were placed in a dedicated cooler and chilled to $4^{\circ} \mathrm{C}$. Samples for laboratory analysis of SVs were chilled to $4^{\circ} \mathrm{C}$. Pesticide samples were filtered onsite and chilled to $4{ }^{\circ} \mathrm{C}$ for transport to the USGS laboratory in Rolla, Missouri, where they were extracted using a C-18 extraction cartridge. The cartridges were chilled and shipped to the USGS water-quality laboratory in Arvada, Colorado, where they were eluted and analyzed. Samples for the determination of XACs were placed in baked-glass bottles and chilled to $4{ }^{\circ} \mathrm{C}$ for transport to the laboratory. All samples were shipped overnight and analyzed within guidelines established in the Sampling and Analysis Plan on file at the USGS in Rolla, Missouri. Analytical methods used for the determination of inorganic and organic constituents in water samples were similar to those used for the regional geohydrologic assessment of the FLWMR (Imes and others, 1996).

\section{Mด}

Existing monitoring wells at SWMUs were installed over several years and had no consistent identifiers. During this assessment the existing overburden and shallow bedrock monitoring wells were renumbered using a prefix of "MW" followed by a three-digit number beginning with 001 (table 3 ). Monitoring wells installed to the regional water table at FLW-002 during this assessment were designated as 200-series monitoring wells. Temporary monitoring wells installed during this assessment at FLW-059 were identified using the prefix "TW" followed by a number.

Five bedrock monitoring wells were installed to depths between 120.1 and $227 \mathrm{ft}$ at FLW-002 in January through February 1997. These were installed using a CME-75 auger drill rig and 8.25-in. ID hollow-stem augers and a Schramm T-64 air rotary drill rig. The boreholes and monitoring wells were installed according to the general requirements for the installation of monitoring wells in Missouri (Missouri Department of
Natural Resources, 1996a). The auger drill rig was used to advance boreholes through the overburden, and the auger flights were used as temporary surface casing. The air rotary drill rig was used to advance an 8-in. ID borehole into the bedrock. Following the completion of the borehole to the desired depth, the drill stem and bit were removed, and the total depth of the borehole was checked with a weighted tape. A small layer of filter sand was placed in the bottom of the borehole prior to the installation of the well screen and riser. All 200series monitoring wells were constructed using 4-in. OD No. 10 slot, 10-ft-long PVC well screens and flush threaded 4-in. OD schedule 80 PVC riser. The well screens and riser sections were fitted with inert o-rings. Stainless steel centralizers were placed at the bottom and top of the well screens and about every $75 \mathrm{ft}$ along the riser. The wells screens were set in a primary filter pack comprised of WB 10-20 sand. A 1- to 3-ft-thick secondary filter pack consisting of WB 20-40 sand was placed above the primary filter pack in several boreholes. The primary and secondary filter packs were installed by washing the filter sand down a 1 -in. ID steel tremie pipe using potable water. A bentonite chip annular seal was placed in most boreholes and allowed to hydrate for a minimum of 4 hours prior to grouting the borehole annulus. A 1-in. ID steel tremie pipe was used to pressure grout the bore annulus from the bottom. During grouting, the tremie pipe was placed $20 \mathrm{ft}$ above the annular seal (or top of secondary filter pack). Completion data for monitoring wells at SWMUs investigated during this study are listed in table 3. Borehole MW-201 was unstable and continuously caved; therefore, to complete the well for use, a bentonite chip annular seal was not installed.

The filter on the air rotary drill rig was changed between each borehole. An explosive-gas meter calibrated to methane and a portable GC were used to monitor the quality of return air from the boreholes. The portable GC was used to monitor for the presence of VOCs introduced into the borehole by the drilling method. Methane concentrations were less than 2 percent of the lower explosive limit (LEL), and no identifiable VOCs were detected by the portable GC. Specific conductance and $\mathrm{Cl}$ concentrations were measured in return water to detect the presence of landfill leachate. Landfill leachate was encountered during the drilling of borehole $\mathrm{MW}-210$, which required the installation of $21 \mathrm{ft}$ of 10 -in. OD schedule 80 PVC surface casing. Borehole MW-211 encountered landfill leachate at depths between 80 and $120 \mathrm{ft}$, and the mon- 
Table 3. Completion data for monitoring and temporary monitoring wells installed at solid-waste management units [All depths in feet below land surface; mp, measuring point; --, no data; PVC, polyvinyl chloride]

\begin{tabular}{|c|c|c|c|c|c|c|c|c|c|c|c|c|}
\hline Well & $\begin{array}{c}\text { Previous } \\
\text { U.S. } \\
\text { Army } \\
\text { identifler }\end{array}$ & $\begin{array}{c}\text { Year } \\
\text { installed }\end{array}$ & $\begin{array}{l}\text { Altitude } \\
\text { of } \mathrm{mp} \\
\text { (above sea } \\
\text { level) }\end{array}$ & $\begin{array}{c}\text { Depth to } \\
\text { bottom } \\
\text { of } \\
\text { hole }\end{array}$ & $\begin{array}{c}\text { Depth to } \\
\text { bottom } \\
\text { of } \\
\text { well }\end{array}$ & $\begin{array}{l}\text { Depth to } \\
\text { top } \\
\text { of } \\
\text { bedrock }\end{array}$ & $\begin{array}{l}\text { Depth to } \\
\text { top of } \\
\text { secondary } \\
\text { filter pack }\end{array}$ & $\begin{array}{l}\text { Depth to } \\
\text { top } \\
\text { of primary } \\
\text { filter pack }\end{array}$ & $\begin{array}{c}\text { Depth to } \\
\text { top } \\
\text { of } \\
\text { screen }\end{array}$ & $\begin{array}{c}\text { Screen } \\
\text { length } \\
\text { (feet) }\end{array}$ & $\begin{array}{c}\text { Well } \\
\text { diameter } \\
\text { (inches) }\end{array}$ & $\begin{array}{c}\text { Depth to } \\
\text { top of } \\
\text { annular } \\
\text { seal }\end{array}$ \\
\hline \multicolumn{13}{|c|}{ FLW-002 } \\
\hline MW 001 & $2 \mathrm{C}$ & 1987 & $1,116.61$ & 22 & 22 & 21 & -- & 4.2 & 11.5 & 10 & 2 & 1.4 \\
\hline MW 002 & 2D & 1987 & $1,118.54$ & 22 & 21.3 & 21 & -- & 11.1 & 10.8 & 10 & 2 & 5.7 \\
\hline MW 003 & DW3 & 1990 & $1,117.96$ & 83 & 82 & 20 & - & 44 & 62 & 20 & 2 & 19 \\
\hline$M W 004^{a}$ & $2 \mathrm{E}$ & 1987 & -- & 29 & 28.5 & - & .. & 15 & 18 & 10 & 2 & 10 \\
\hline MW 005 & DW2 & 1990 & $1,130.23$ & 83 & 83 & 7 &.- & 55 & 63 & 20 & 2 & 48 \\
\hline MW 006 & DW1 & 1990 & $1,154.94$ & 100 & 96.7 & 7 & -- & 45 & 66.7 & 30 & 2 & 33 \\
\hline MW $007^{\mathrm{a}}$ & 2B & 1987 & - & 25 & 24.5 & 5 & -- & 10.8 & 14 & 10 & 2 & 7.3 \\
\hline$M W 008^{a}$ & $2 \mathrm{~A}$ & 1987 & - & - & 25.4 & -- & - & 5.8 & 14.9 & 10 & 2 & 2.6 \\
\hline MW-201 & -- & 1997 & $1,152.83$ & 231.5 & 227 & 8 & 204.5 & 214.5 & 216.5 & 10 & 4 & -- \\
\hline MW-209 & -- & 1997 & $1,142.00$ & 226.5 & 219.5 & 8 & -- & 201.5 & 209 & 10 & 4 & 200 \\
\hline $\mathrm{MW}-210^{\mathrm{b}}$ & -- & 1997 & $1,122.38$ & 204 & 196.5 & 13 & 175 & 177 & 186 & 10 & 4 & 173.5 \\
\hline MW-211 & -- & 1997 & $1,119.90$ & 124 & 120.1 & 20.5 & 100 & 103 & 109.6 & 10 & 4 & 93 \\
\hline MW-212 & -- & 1997 & $1,125.94$ & 204 & 201.5 & 15.5 & -- & 183 & 191 & 10 & 4 & 180 \\
\hline \multicolumn{13}{|c|}{ FLW-003 } \\
\hline MW 001 & MW1 & 1990 & $1,141.05$ & 103 & 101.5 & 20 & - & 81 & 91.5 & 10 & 2 & 76 \\
\hline MW 002 & $3 A-4$ & 1987 & -- & 14.5 & 14.5 & 14 & - & 4 & 6.3 & 8 & 2 & -- \\
\hline MW 003 & MW2 & $\cdot 1990$ & $1,103.95$ & 57 & 58 & 9 & - & 15 & 38 & 20 & 2 & 8 \\
\hline MW 004 & $3 A-2$ & 1987 & - & - & 43.1 & -- & - & 20 & 22.6 & 20 & 2 & 13 \\
\hline MW 005 & $3 A-1$ & 1987 & - & 42.1 & 42 & 43 & - & 10 & 21.5 & 20 & 2 & 3.1 \\
\hline \multicolumn{13}{|c|}{ FLW-004 } \\
\hline MW 001 & $3 \mathrm{~B}-1$ & 1987 & - & 47 & 43.4 & -- & -- & 5 & 22.9 & 20 & 2 & - \\
\hline MW 002 & 3B-2 & 1987 & - & 47.7 & 47.7 & 47 & - & 25.4 & 27.2 & 20 & 2 & 18.5 \\
\hline \multicolumn{13}{|c|}{ FLW-005 } \\
\hline MW 001 & $3 C-1$ & 1987 & - & 26 & 24.5 & 26 & - & 10.6 & 14 & 10 & 2 & 6.3 \\
\hline MW 002 & $3 C-4$ & 1987 & - & 13 & 13 & 13 & -- & 3.3 & 5.8 & 7 & 2 & -- \\
\hline MW 003 & MW3 & 1990 & $1,079.32$ & 103 & 101 & 1 & - & 52 & 71 & 30 & 2 & 48 \\
\hline MW 004 & $3 C-5$ & 1987 & - & 10 & 8 & 10 & - & 1.2 & 2.8 & 5 & 2 & - \\
\hline MW 005 & $3 C-8$ & 1987 & -- & 37 & 32 & 30 & - & 16.4 & 22 & 10 & 2 & 12.9 \\
\hline MW 006 & $3 C-7$ & 1987 & - & 53 & 47.7 & $53^{\circ}$ & - & 8.2 & 27.2 & 20 & 2 & 3.2 \\
\hline MW 007 & $3 C-6$ & 1987 & - & 47 & 47 & 47 & - & 7 & 26.5 & 20 & 2 & - \\
\hline MW 008 & $3 C-2$ & 1987 & -- & 10.2 & 10.2 & 9 & -- & 2.5 & 4.2 & 6 & 2 & -- \\
\hline MW 009 & MW4 & 1990 & $1,109.32$ & 103 & 100.5 & 8 & - & 21 & 80.5 & 20 & 2 & 18 \\
\hline \multicolumn{13}{|c|}{ FLW-059 } \\
\hline $\mathrm{TW} 002^{\mathrm{a}}$ & -- & 1997 & -- & 18 & -- & -- & - & -- & 13 & 5 & 1.25 & - \\
\hline TW 004 & -- & 1997 & - & 20 & -- & -- & - & -- & 15 & 5 & 1.25 & - \\
\hline TW 006 & - & 1997 & -- & 18 & -- & -- & - & - & 13 & 5 & 1.25 & -- \\
\hline TW 008 & -. & 1997 & .- & 20 & .- & -- & - & -- & 15 & 2 & 1.25 & -- \\
\hline
\end{tabular}

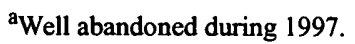

b Surface casing ( 10 -inch outside diameter schedule $80 \mathrm{PVC}$ ) installed to 19 feet below land surface. 
itoring well was set at a relatively shallow depth (120.1 $\mathrm{ft}$ ) to monitor perched water within the bedrock. Monitoring wells were developed after completion by alternating surging with a surge block and bailing for a minimum of 4 hours or until the amount of water used in the drilling of each borehole was removed, regardless of the clarity of the water.

Temporary monitoring wells were installed at FLW-059 using a tractor-mounted drill rig equipped with 3-in. ID hollow-stem augers. The temporary monitoring wells were constructed using No. 10 slot, 5-ftlong schedule 40 PVC screens and flush threaded 1-in. OD PVC risers. After the desired depth was reached, the inside of the auger flights was filled with potable water, and a steel rod was used to remove a knock-out plate in the auger bit. The well screen and riser were set inside the augers. After the installation of the well screen and riser, the augers were pulled, and the borehole was allowed to collapse around the well screen and riser. The remaining annulus to the surface was filled with bentonite grout. The temporary monitoring wells were developed by mechanically surging and bailing for a minimum of 2 hours. Most temporary wells recovered slowly, and the water remained turbid after development. After sampling, the temporary monitoring wells were abandoned by removing the well screen and riser and filling the annulus with bentonite grout.

\section{Dye-Trace Tests}

Background fluorescent spectra checks and attempted dye recoveries were made by placing approximately $10 \mathrm{~g}$ of activated coconut charcoal encased in a fiberglass mesh into flowing surface water. The charcoal packets were kept immersed from a few days to about 2 weeks. After retrieval from the water, each charcoal packet was washed with clean water, dried, and split into two samples of approximately equal weight. One-half of the sample was archived in case the analysis needed to be repeated. The other onehalf was eluted in a solution of 95 percent isopropyl alcohol and 5 percent ammonium hydroxide by volume. The elutant solution was analyzed for the presence of fluorescent materials using a scanning spectrofluorophotometer adjusted to illuminate the solution using a range of excitation wavelengths from 300 to $650 \mathrm{~nm}$ (nanometers) and monitor the fluorescence (emission) spectra from 320 to $670 \mathrm{~nm}$ using a 3$\mathrm{nm}$ window at a $+20-\mathrm{nm}$ shift from the excitation wavelength. All analyses were qualitative. The reader is referred to Mull and others (1988) for a review of standard dye-tracing techniques.

\section{SPRING CHARACTERIZATION}

Springs along the Big Piney River and lower part of Roubidoux Creek ultimately discharge a considerable part of the recharge that falls a rainfall on the FLWMR. The detection of PCE in Shanghai Spring and the presence of losing streams and sinkholes at the FLWMR necessitate a thorough delineation of the boundaries of spring recharge basins to determine the direction of potential contaminant migration from SWMUs and other facilities. Dye-trace tests initiated during the regional geohydrologic assessment of the FLWMR (Imes and others, 1996) were continued during this assessment to further refine the boundaries of spring recharge basins. In addition, a more thorough examination of the flow characteristics and PCE concentrations at Shanghai Spring was conducted.

\section{Recharge Basin Delineation}

Dye-trace tests conducted during this assessment have helped to further refine the boundaries of spring recharge basins previously determined by Imes and others (1996) in the vicinity of landfills FLW-002, FLW-003, FLW-004, and FLW-005, and ground-water flow rates from recharge source areas to Shanghai Spring (fig. 5). Twelve dye-trace tests using fluorescent dyes were conducted between December 1995 and June 1997. Background dye concentrations at potential recovery sites were monitored before dye injection to ensure that the source of recovered dye was the injected dye. Results of the assessments indicate that a substantial part of the northern part of FLWMR, including FLW-028, FLW-037, and FLW-056, lie within the Shanghai Spring recharge basin, which encompasses about $27 \mathrm{mi}^{2}$ (square miles). The recharge basin of Sandstone Spring is about $3 \mathrm{mi}^{2}$ and contains FLW-040 (fig. 5). The SWMUs FLW-003, FLW-004, and FLW005 are on or near the boundary between the Shanghai Spring and Sandstone Spring Basins. Solid-waste management unit FLW-002 lies near the distal end of the Miller Spring recharge basin, which is about $17 \mathrm{mi}^{2}$.

Dye-trace test T103-08 was started on December 8,1995 , with the injection of about $4 \mathrm{~L}$ of Rhodamine WT dye into a broad shallow sinkhole on the east side 
of road FLW 20 in the west-central part of the FLWMR. The injection included a 1,000-gal pre-injection flush and 1,000-gal post-injection flush. Water began to pool in the sinkhole orifice after about the first 750 gal of flush water. Flow into the sinkhole was slow after the flush water pooled. Dye from this injection was not recovered at any spring and probably was bound in the clay and silt that presumably restricted flow into the sinkhole. A summary of the dye-injection data and attempted recovery sites is presented in table $\mathrm{A} 1$, appendix at the back of this report.

Dye-trace test T103-09 was begun on January 18,1996 , by injecting $2.5 \mathrm{lbs}$ (pounds) of Fluorescein dye into an opening in the northeastern corner of a small sinkhole in the firing fan of Range 5, southeast of the intersection of roads FLW 1 and FLW 30. Runoff from a rain at the time of injection provided water to flush the dye into the ground. Dye from this injection was recovered at Miller Spring, $4.25 \mathrm{mi}$ east-southeast of the injection site. The approximate time of travel of dye from the injection site to the recovery site based on peak recovery was 19 to 26 days, a travel rate of about $0.2 \mathrm{mi} /$ day (mile per day). Dye-trace injection and recovery data are presented in tables A2 and A3, appendix at the back of this report, and the relative fluorescence intensity of dye eluted from activated charcoal used to collect and concentrate the dye at Miller Spring is shown in figure 6.

Dye-trace test T103-10 began on February 13, 1996 , with the injection of $0.5 \mathrm{lb}$ of Eosine OJ dye in a losing reach of Dry Creek near the FLWMR STP outflow. The dye was placed into flowing water about 12 $\mathrm{ft}$ upstream from the point where stream flow was lost into the streambed. Dye from this injection appeared in Shanghai Spring, about $2.78 \mathrm{mi}$ northeast of the injection site, about 13 to 17 days after injection, a travel rate of about $0.2 \mathrm{mi} /$ day. Dye-trace injection and recovery data are presented in tables A4 and A5, appendix at the back of this report.

Dye-trace test T103-11 was conducted on February 27,1996 , to determine the fate of water injected into a sinkhole next to a losing reach of Smith Branch north of Bloodland Lake near grenade Range 31.

Approximately $2.5 \mathrm{~L}$ of Rhodamine WT dye was used as the tracer. Because of limited accessibility, the dye was not flushed into the ground. However, the ground was saturated from recent rain, and surface runoff from subsequent rainfall flushed the dye. The dye was recovered at Miller Spring, $4.70 \mathrm{mi}$ east of the injection site, 12 to 23 days after injection. The travel rate of the dye is estimated at $0.3 \mathrm{mi} /$ day. Dye-trace injection and recovery data for dye-trace test T103-11 are presented in tables A6 and A7, appendix at the back of this report.

Dye-trace test T103-12 was inconclusive. On March 1, 1996, dye was injected into monitoring well MW 003 (MW3) located at the north edge of FLW-005. About $1 \mathrm{~kg}$ of Fluorescein dye was injected into the monitoring well followed by a flush of more than 1,000 gal of water. The dye appeared to be recovered at Sandstone and Shanghai Springs; however, the background concentrations of Fluorescein dye at these springs from previous dye-trace assessments were large and interfered with the evaluation of the results. A summary of the dye-injection data and attempted recovery sites is presented in table $\mathrm{A} 8$, appendix at the back of this report.

Dye-trace test T103-13 was begun on January 8, 1997, by injecting $2.5 \mathrm{~L}$ of Rhodamine WT dye into a losing reach of Smith Branch $0.5 \mathrm{mi}$ downstream from Bloodland Lake near Range 31 . The dye was flushed into the ground-water flow system by infiltrating streamflow. Dye from this injection was recovered at Miller Spring, $4.61 \mathrm{mi}$ east of the injection site. The approximate time of travel of dye from the injection site to the recovery site, based on peak recovery, was 20 to 25 days, a travel rate of about $0.2 \mathrm{mi} /$ day. Dye-trace injection and recovery data for trace test T103-13 are presented in tables A9 and A10, appendix at the back of this report.

Dye-trace test T103-14 began with the injection of 3.5 to $4.0 \mathrm{lbs}$ of Fluorescein dye on January 23, 1997, into monitoring well MW 003 on the north edge of FLW-005. This dye-trace test was a repeat of test T103-12, which was inconclusive because of large background dye concentrations. Fluorescein dye was initially flushed into the ground-water flow system with 200 gal of water, which was followed at a later date by a flush using about 4,000 gal of water. The flush water easily flowed through the well bore into the aquifer at a rapid rate with no indication of blockage. Dye was recovered at Sandstone Spring, $3.11 \mathrm{mi}$ east of the injection site. The approximate time of travel of dye from the injection site to the recovery site, based on peak recovery, was 20 to 26 days, a travel rate of about 0.1 to $0.2 \mathrm{mi} /$ day. Dye also may have been recovered at Shanghai Spring, about $8 \mathrm{mi}$ northeast of the injection site after about 11 days; however, the magnitude of the dye peak at recovery was not large enough to state conclusively that the observed dye was not residual dye 


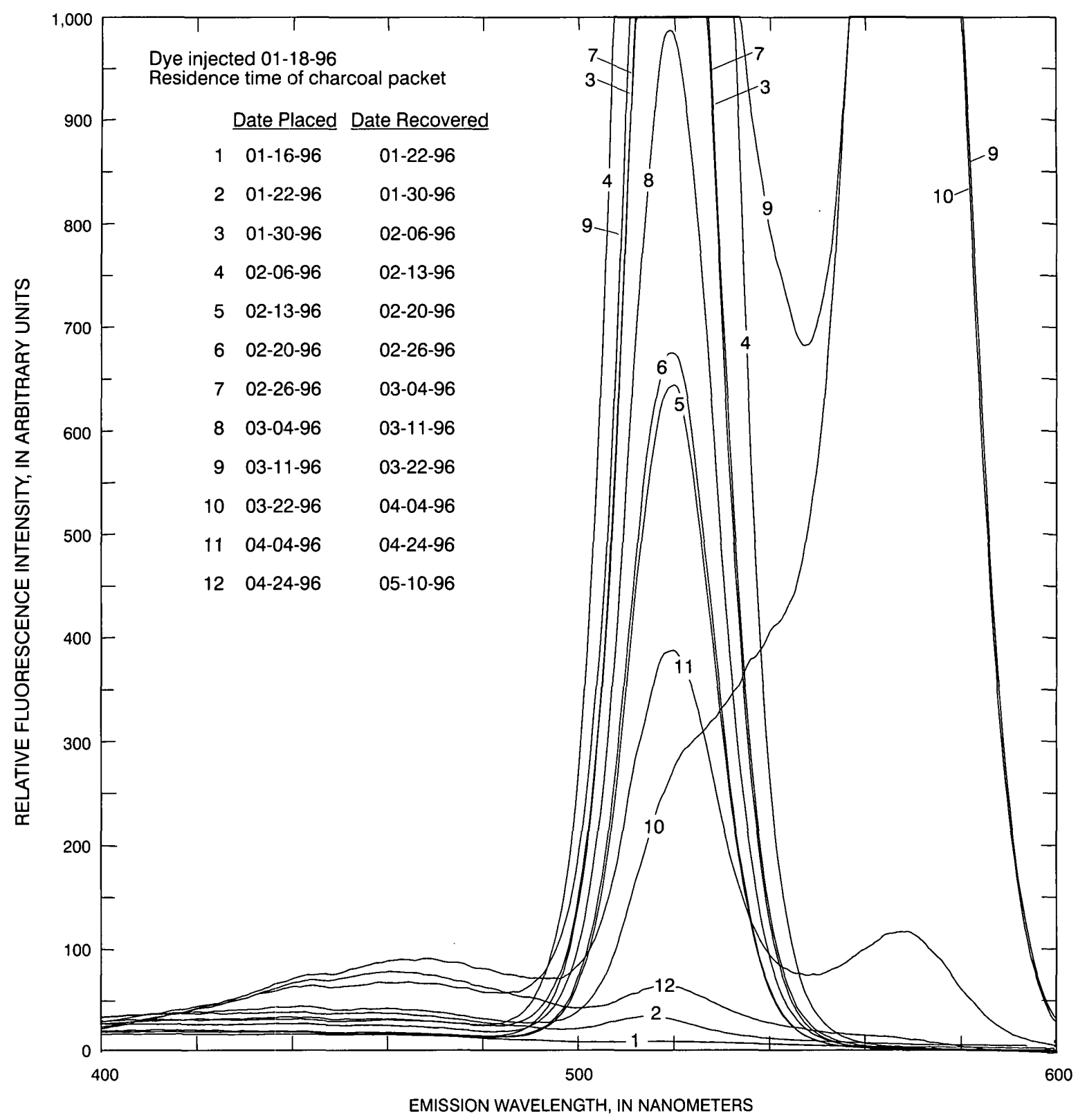

Figure 6. Spectral analysis of fluorescent material extracted from activated charcoal packets placed in Miller Spring during dye-trace test T103-09.

from previous traces. Dye-trace injection and recovery data for trace test T103-14 are presented in tables A11 and A12, appendix at the back of this report.

Dye-trace test T103-15 was begun on February 28,1997 , by injecting $4 \mathrm{~L}$ of Rhodamine WT dye into a newly opened sinkhole located about $100 \mathrm{ft}$ east of road FLW 15 about 1 mi north of FLW-040. Two hundred gallons of water was flushed into an opening in the bottom of the sinkhole, and the dye injection was followed by an additional flush using 1,800 gal of water.
The dye from this injection was not recovered at any spring, probably because the dye was bound in the clay, silt, and organic matter in the sinkhole, or the water carrying the dye was trapped or emerged at an unknown location. A summary of the dye-injection data and attempted recovery sites is presented in table A13, appendix at the back of this report.

Dye-trace test T103-16 was conducted as part of an assessment of storm-event discharge and water quality at Shanghai Spring. Because accurate travel times 
were required for the study, dye was recovered from Shanghai Spring in water samples collected using an automatic sampler driven by a data recorder.

Rhodamine WT dye was injected on May 30, 1997, into a large sinkhole north of Forney Army Airfield-the same sinkhole used as an injection point for dye-trace test T103-01, as reported in Imes and others (1996). Rain provided the pre-injection flush, which was followed by 1,500 gal of post-injection flush water. The peak dye concentration in the collected water samples occurred June 3, 1997. The time of travel for the $6.55 \mathrm{mi}$ from injection to recovery site, based on the peak recovered concentration, was 98 hours. The rate of travel was $1.60 \mathrm{mi} /$ day. Dye-trace injection and recovery data for dye-trace test T103-16 are presented in tables A14 and A15, appendix at the back of this report.

Dye-trace test T103-17 also was conducted as part of an assessment of storm-event discharge and water quality at Shanghai Spring. Eosine OJ dye was injected on May 27, 1997, into a losing reach of Dry Creek during runoff conditions about $600 \mathrm{ft}$ upstream from the FLWMR STP outfall. Water had not begun flowing in Dry Creek at the time of injection. Stream losses to the ground-water flow system provided the pre- and post-injection flush. Dye was recovered from Shanghai Spring in water samples collected using an automatic sampler driven by a data recorder. The peak dye concentration occurred May 30, 1997. The time of travel for the $2.78 \mathrm{mi}$ from injection to recovery site, based on the peak recovered concentration, was 86.4 hours. The rate of travel was $0.77 \mathrm{mi} /$ day. Dye-trace injection and recovery data for dye-trace test T103-17 are presented in tables A16 and A17, appendix at the back of this report.

Dye-trace test T103-18 was conducted to determine if the downstream-most losing reach of Smith Branch is connected through a karst conduit system to Roubidoux Spring or Shanghai Spring. One charcoal packet placed in the spring branch of Roubidoux Spring absorbed significant quantities of dye; however, none of the other packets absorbed dye. It is thought that the recovered dye resulted from submersion of the charcoal packet by backwater from Roubidoux Creek during a brief period of high water, not from dye moving through the spring. This test was, therefore, determined to be inconclusive. A summary of the dyeinjection data and attempted recovery sites is presented in table A18, appendix at the back of this report.
Dye-trace test T002-01 was conducted as part of an assessment of sediment transport from the Normandy Training Area where army engineers are trained in the operation of heavy equipment. The test began on June 17, 1997, with the injection of 4 gal of Fluorescein dye into water flowing from the emergency spillway at sediment pond 3 at the junction of the spillway and Smith Branch. It was known from previous assessments that sediment pond 3 was constructed on karst features that are part of the Shanghai Spring recharge basin. Fluorescein dye from this trace was detected in water samples collected from Shanghai Spring $8.90 \mathrm{mi}$ northeast of the injection site. The peak dye concentration occurred on July 3, 1997, with a travel time of 15.9 days and a rate of travel of $0.56 \mathrm{mi} /$ day. Dye was also recovered from charcoal packets placed at the mouth of Smith Branch about $3.35 \mathrm{mi}$ downstream from the injection site. Dye injection and recovery data for this test is presented in tables A19, A20, and A21, appendix at the back of this report.

\section{Geohydrology and Water Quality of Shanghai Spring}

Shanghai Spring is located along the Big Piney River about $2.5 \mathrm{mi}$ northeast of the northern FLWMR boundary. The water rises from a pool about $40 \mathrm{ft}$ in diameter at the base of a bluff in the Gasconade Dolomite. Discharge from the spring flows about $500 \mathrm{ft}$ through a small channel before it flows into the Big Piney River. During periods of extremely high flow, backwater from the Big Piney River covers the spring orifice, and spring flow also may discharge from a small cave about $10 \mathrm{ft}$ above the spring orifice (Vineyard and Feder, 1974). Based on an average of 12 discharge measurements made between 1925 and 1966, Vineyard and Feder (1974) estimated the average baseflow discharge of Shanghai Spring to be about $18 \mathrm{ft}^{3} / \mathrm{s}$. The minimum measured discharge of $7.70 \mathrm{ft}^{3} / \mathrm{s}$ was on August 3, 1934; the maximum measured discharge of $73.3 \mathrm{ft}^{3} / \mathrm{s}$ was on May 31, 1997, as part of data collection for this study.

Previous dye-trace tests have indicated a subsurface connection between losing tributaries downstream from the St. Robert and the FLWMR STPs and Shanghai Spring, and, as a result, the water quality of the spring has been degraded (Vineyard and Feder, 1974). Water-quality samples have been collected from Shanghai Spring by various agencies since 1925 (table 4 , at the back of this report). Historically, concentra- 
tions of $\mathrm{Cl}$ and $\mathrm{NO}_{2 \mathrm{t}}+\mathrm{NO}_{3 \mathrm{t}}$ in samples from Shanghai Spring commonly have been larger than the range of concentrations in water samples from other springs in the Gasconade River Basin (fig. 7) determined by Vineyard and Feder (1974). The average concentrations of $\mathrm{Na}(7.1 \mathrm{mg} / \mathrm{L}), \mathrm{Na}_{\mathrm{t}}(7.6 \mathrm{mg} / \mathrm{L}), \mathrm{Cl}(9.0 \mathrm{mg} / \mathrm{L})$, dissolved fluoride $(\mathrm{F})(0.2 \mathrm{mg} / \mathrm{L}), \mathrm{NO}_{2 \mathrm{t}}+\mathrm{NO}_{3 \mathrm{t}}(2.0$ $\mathrm{mg} / \mathrm{L}$ ), $\mathrm{P}_{\mathrm{t}}(0.16 \mathrm{mg} / \mathrm{L}$ ), B [32 $\mu \mathrm{g} / \mathrm{L}$ (microgram per liter $)]$, and $B_{t}(36 \mu g / L)$ in water samples collected from Shanghai Spring during this assessment (1995 to 1997) also were larger than the background concentrations estimated by Imes and others (1996) in springs from the FLWMR and vicinity (table 4). Imes and others (1996) also reported that water samples collected from Shanghai Spring contained detectable concentrations of PCE $(0.6$ to $1.8 \mu \mathrm{g} / \mathrm{L})$ and of the pesticides prometon and simazine $(0.008$ and $0.006 \mu \mathrm{g} / \mathrm{L})$.

The water quality of springs in karst terrane can undergo rapid degradation during runoff events (Ryan and Meiman, 1996). The degradation is usually brief, and a detailed flow-dependent sampling program is necessary to monitor the magnitude of these effects. A continual gaging and automatic water-quality monitoring station was installed at Shanghai Spring on March 28,1997 , to monitor the changes in water quality during runoff. The station recorded stage, specific conductance, and water temperature every 15 minutes. The automatic water-quality sampler collected water samples during runoff events at 4- to 8-hour intervals, depending on whether the stage was rising or falling. Manual VOC samples were collected by an observer several times daily during runoff. Rainfall near the southern end of the Shanghai Spring Basin was recorded every 15 minutes by a U.S. Army meteorological station near Forney Army Airfield.

As part of the additional characterization of Shanghai Spring, semi-quantitative dye-trace tests were conducted during two runoff events from locations known to be connected to Shanghai Spring. The dye was injected at the onset of runoff. By comparing
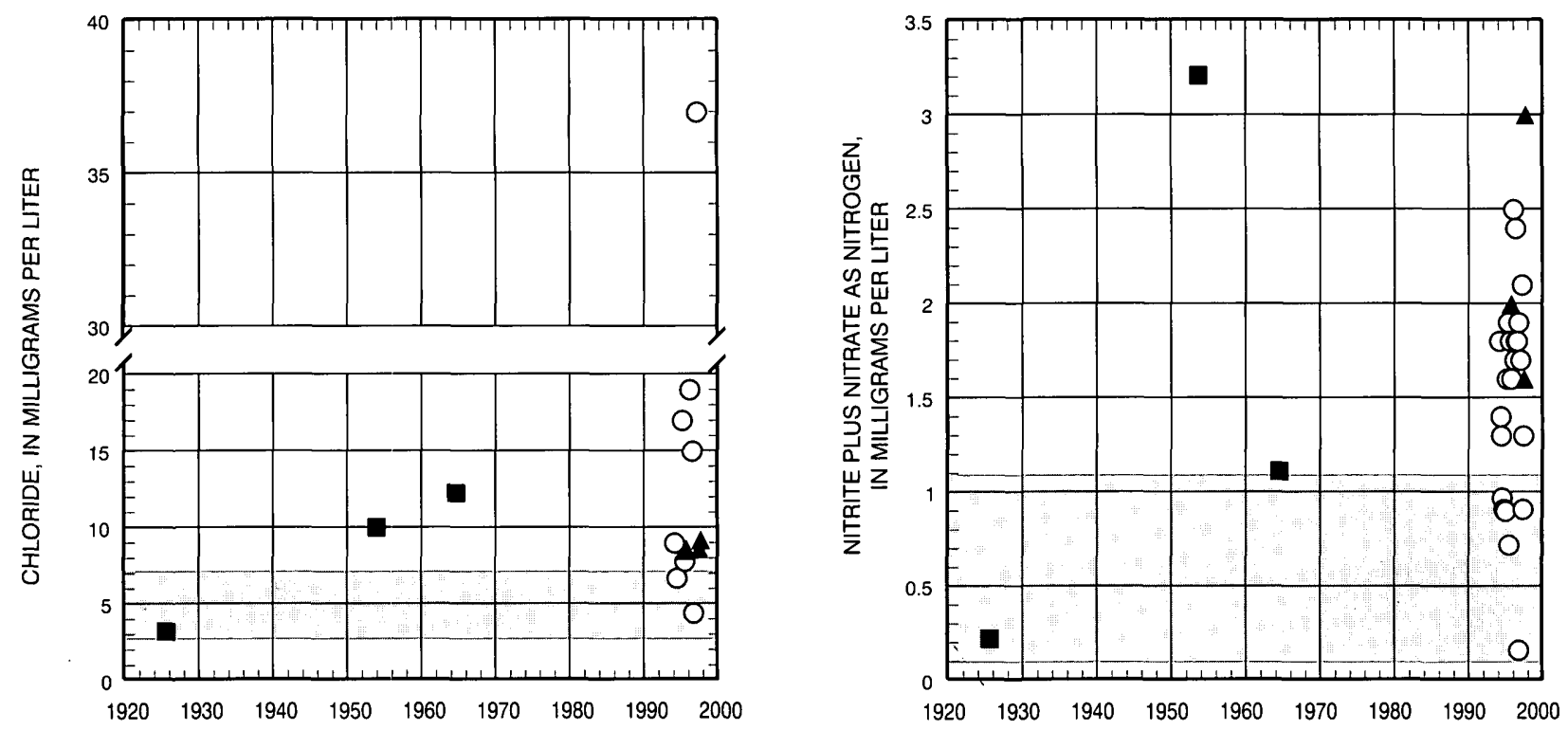

EXPLANATION

SHADED REGION REPRESENTS THE 25TH TO 95TH PERCENTILE RANGE OF CONCENTRATIONS IN WATER SAMPLES FROM SPRINGS IN THE GASCONADE RIVER BASIN

- DATA FROM VINEYARD AND FEDER (1974)

O DATA COLLECTED BY THE U.S. GEOLOGICAL SURVEY FROM 1993 TO 1997

- DATA COLlECTED BY THE U.S. GEOLOGICAL SURVEY DURING THIS INVESTIGATION

Figure 7. Concentrations of chloride and nitrite plus nitrate (as nitrogen) in samples from Shanghai Spring compared to concentrations reported in samples from other springs in the Gasconade River Basin. 
the arrival times and concentration of dye to variations in discharge, specific conductance, and concentration of chemical constituents, improved understanding of the nature of the spring conduit system and potential sources of contaminants to the spring was obtained.

Specific conductance at Shanghai Spring varies inversely with discharge. Generally, specific conductance increased and discharge decreased during the spring and summer months (fig. 8). This general trend was punctuated with periods of rapidly increasing discharge and decreasing specific conductance in response to runoff. Discharge at Shanghai Spring increases almost immediately after the onset of rainfall-induced runoff. The specific conductance response occurs more slowly than the discharge response, with the initial decrease in specific conductance occurring during the recession limb of the discharge hydrograph-well after the peak discharge has occurred. Following runoff, discharge returned to prerunoff conditions much more quickly than did specific conductance. The lag between the initial discharge response and decrease in specific conductance (signaling the arrival of relatively low-ionic strength runoff) in springs in response to runoff has been interpreted to represent the time required to displace pre-runoff water in the phreatic (water-filled) conduits between the recharge points and the spring orifice (Hess and White, 1988; Driess, 1989; Meiman, 1989).

The response of discharge and specific conductance at Shanghai Spring to runoff was examined during four selected runoff events: May 26, 1997 (event I), May 30, 1997 (event II), June 13, 1997 (event III), and August 19, 1997 (event IV). Events I and II were proceeded by several days of moderate rainfall (fig. 9).

During event I, the discharge at Shanghai Spring began increasing at 0045 on May 26, 1997. Specific conductance did not begin to decrease (arbitrary threshold of 2 percent difference between measurements was used) until 2145 on May 28, 1997, about 65.25 hours after the initial discharge response (fig. 9). A similar response of discharge and specific conductance was observed during event II. A relatively intense thunderstorm initiated runoff event III and the discharge at Shanghai Spring began increasing almost immediately after the onset of rainfall. The nearly immediate response of discharge and lag in the response of specific conductance can be attributed to runoff quickly entering the upper end of a major phreatic (that is, under water-table conditions)

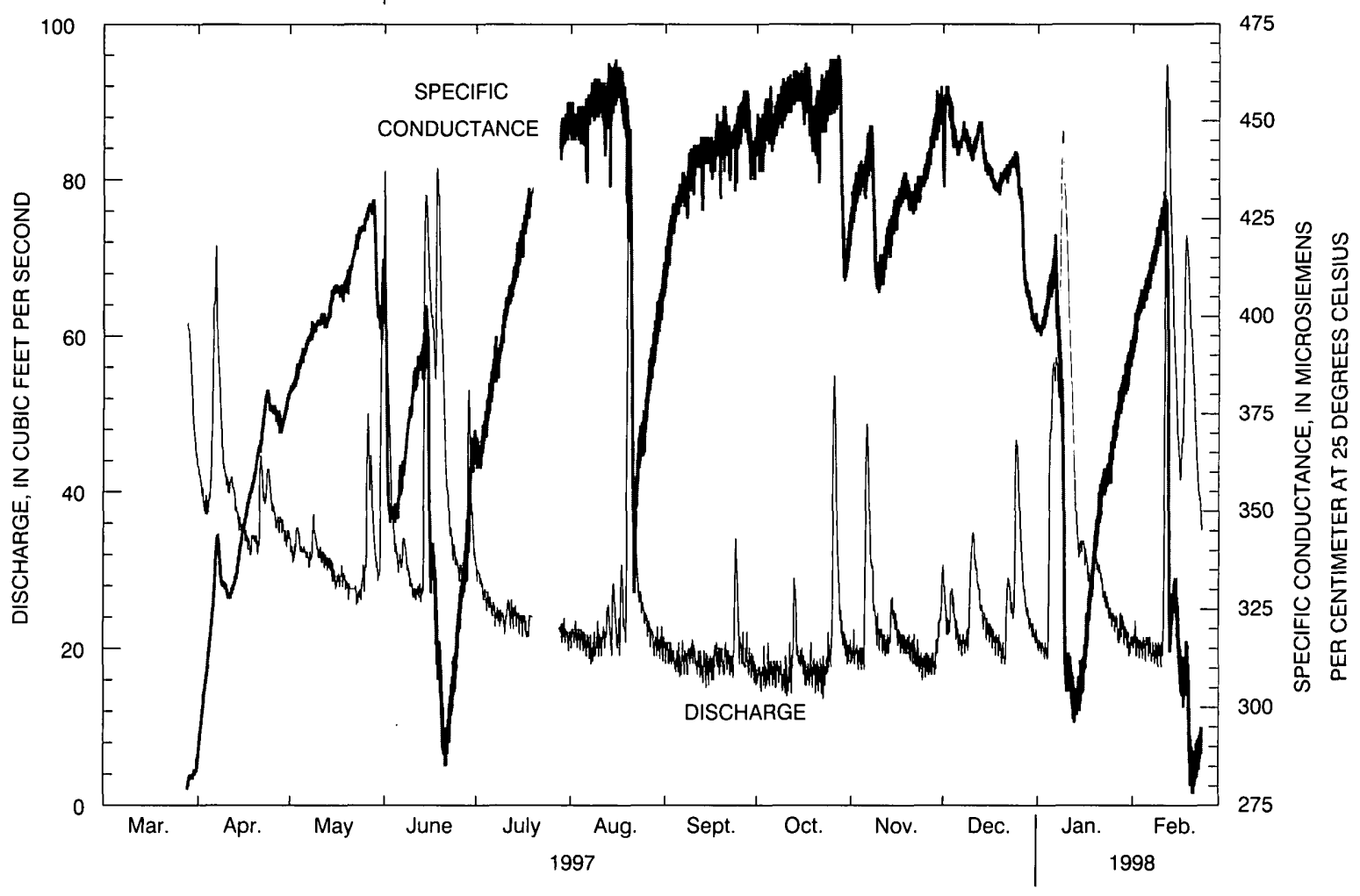

Figure 8. Instantaneous discharge and specific conductance at Shanghai Spring, March 28, 1997, through February 28, 1998. 


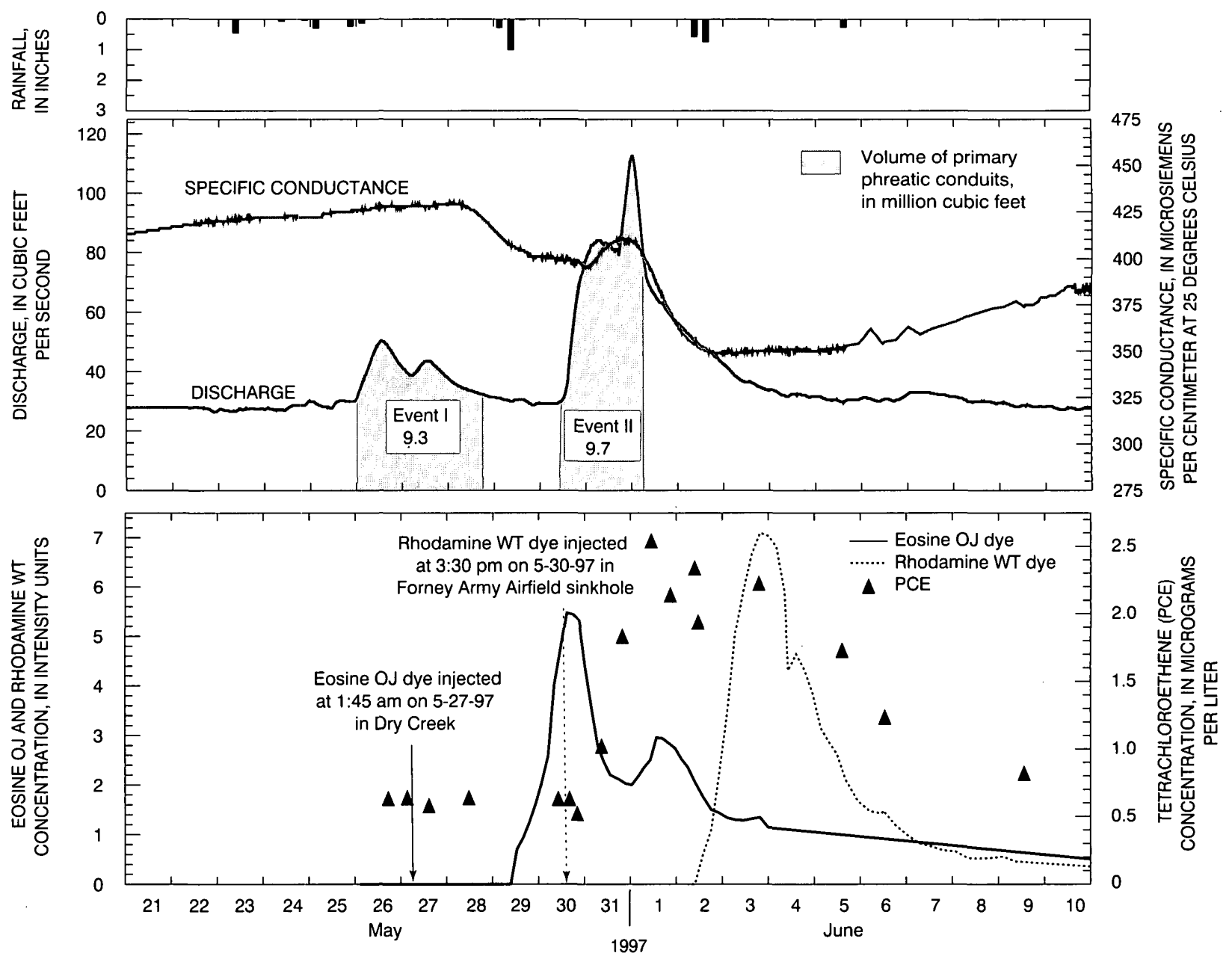

Figure 9. Instantaneous discharge, specific conductance, and concentrations of Eosine OJ and Rhodamine WT dye and tetrachloroethene (PCE) in water samples from Shanghai Spring, May 21 through June 10, 1997.

conduit causing the hydrostatic head to be rapidly propagated through the conduit to the spring orifice (Atkinson, 1977). By integrating the area beneath the discharge hydrograph between the time of initial discharge and initial specific conductance responses, the volume of primary phreatic conduit storage was calculated to be about $9.3 \mathrm{mcf}$ (million cubic feet). Despite the extensive and complex nature of the conduit system, multiple potential points of quick recharge to the conduits, and variation in rainfall patterns between storms, the calculated volume of the phreatic conduits was similar for the four events studied; $9.7 \mathrm{mcf}$ for event II (fig. 9), $8.7 \mathrm{mcf}$ for event III (fig. 10), and 9.0 mcf for event IV (fig. 11). Although the calculated phreatic conduit volumes were similar, the times between the discharge and specific conductance responses were not (65.25 hours, event I; 40.5 hours, event II; 34.5 hours, event III; 33.5 hours, event IV).
The variation in the temporal lag between discharge and specific conductance responses probably is related to the distribution of rainfall throughout the spring basin, rainfall intensity, and antecedent conditions.

Quantitative dye-trace tests were conducted from Dry Creek 0.25 mi upstream from the FLWMR STP to Shanghai Spring (2.7-mi trace) during runoff event I and from a sinkhole near Forney Army Airfield to Shanghai Spring (6.6-mi dye trace) during runoff event II (fig. 9). Dye was recovered at Shanghai Spring using charcoal packets and an automatic water-quality sampler. During runoff event I, about $1.1 \mathrm{~kg}$ of Eosine OJ dye (pre-mixed in $16 \mathrm{~L}$ of tap water) was injected into Dry Creek about 0145 on May 27, 1997. The Eosine OJ dye was injected immediately after water began flowing at this site. The creek was dry before runoff and reached a maximum estimated discharge of $15 \mathrm{ft}^{3} / \mathrm{s}$ within 15 minutes of the dye injection. Of the 


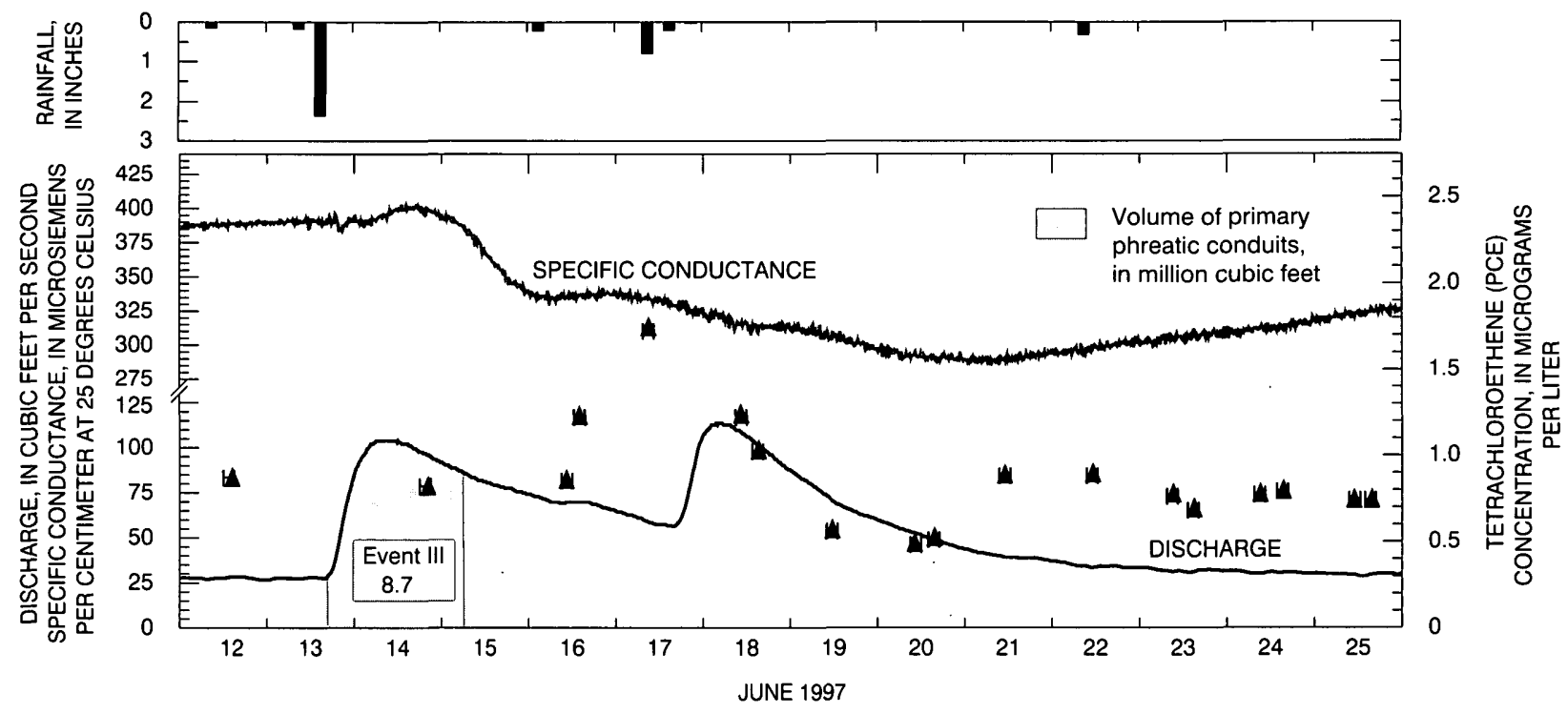

Figure 10. Instantaneous discharge, specific conductance, and tetrachloroethene (PCE) concentration in water samples from Shanghai Spring, June 12 through June 25, 1997.

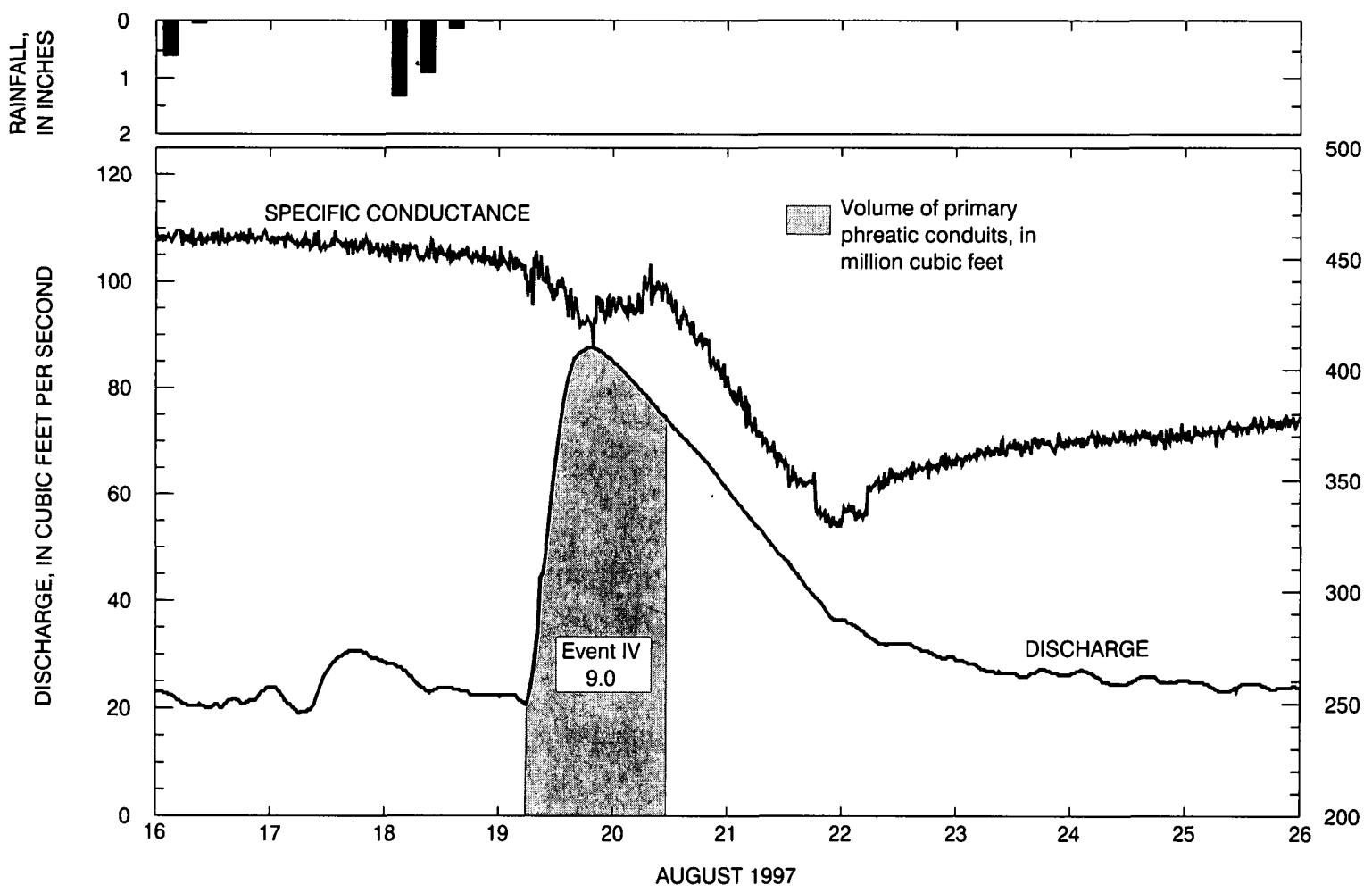

Figure 11. Instantaneous discharge and specific conductance at Shanghai Spring, August 16 through August 26, 1997. 
dye injected in Dry Creek, about $0.8 \mathrm{~kg}$ (73 percent) was recovered at Shanghai Spring during a 6-day period. During runoff event II, $1.2 \mathrm{~kg}$ of Rhodamine WT dye was injected into a sinkhole north of Forney Army Airfield at 1530 on May 30, 1997. The

Rhodamine WT dye injection was proceeded with a 250-gal tap water flush followed by post-injection flush of more than $1,000 \mathrm{gal}$ of tap water. Of the dye injected at the airfield sinkhole, about $0.5 \mathrm{~kg}$ (42 percent) was accounted for at Shanghai Spring over a 9day period. Although, the airfield trace was more than twice the length of the Dry Creek trace, the travel time of dye from the sinkhole to Shanghai Spring (98 hours) was only about 13 percent longer than that from Dry Creek to the spring (86.4 hours).

Similar to specific conductance values, concentrations of certain inorganic chemical constituents, such as $\mathrm{Ca}$, in water samples from Shanghai Spring generally decreased following runoff, indicating dilution by the relatively low-ionic strength runoff water. The response in $\mathrm{Cl}$ and $\mathrm{B}$, however, was not as closely related to specific conductance. Chloride concentrations exhibited little change during runoff, indicating $\mathrm{Cl}$ concentrations in the runoff were nearly the same as those in the base-flow component (fig. 12). Concentrations of $\mathrm{B}$ generally exhibited a similar response as $\mathrm{Ca}$ concentrations except that between June 11 and June 16,1997 , B concentrations inexplicably increased more than 30 percent. Although constituent concentrations tended to decrease following a runoff event, loads of these constituents increased with increasing discharge following runoff (fig. 12). The increase in constituent loads following runoff, despite the decrease in concentrations, indicates that runoff is not replacing the pre-event base-flow ground-water component supplying the spring, but, mixing with and adding to, the ground-water component during runoff. Molar ratios of $\mathrm{Ca} / \mathrm{Mg}$ in runoff samples (1.02 to 1.15 ) were similar to molar ratios in summer low base-flow samples collected on August 15, 1995 (1.09), and July 28, 1997 (1.11). The similarity in molar $\mathrm{Ca} / \mathrm{Mg}$ ratios suggests that dissolution of dolomitic rock in the unsaturated and shallow saturated zones by infiltrating runoff contributes to the increase in $\mathrm{Ca}$ and $\mathrm{Mg}$ loads during runoff.

Concentrations of PCE were first detected in water samples collected from Shanghai Spring during 1995 (Imes and others, 1996); however, these samples apparently were the first samples from Shanghai Spring analyzed for VOCs. Concentrations of PCE in six samples submitted for laboratory analysis collected during 1995 and 1997 ranged from 0.6 to $1.8 \mu \mathrm{g} / \mathrm{L}$ (table 4). Concentrations of PCE were determined in more than 50 water samples collected from Shanghai Spring (mainly during runoff) during 1997 using a portable GC (table 5, at the back of this report). Field determined concentrations of PCE in the spring samples ranged from 0.3 to $3.7 \mu \mathrm{g} / \mathrm{L}$ (mean of $1.1 \mu \mathrm{g} / \mathrm{L}$ ) and generally increased following runoff. During runoff events II and III, PCE concentrations seemed to peak between 24 and 48 hours after onset of the decrease in specific conductance (figs. 9, 10). Because of the relatively short interval between events I and II, there is some uncertainty as to whether the PCE concentrations were responding to event I or event II. The increase in PCE concentrations following runoff indicates that infiltrating rainfall or runoff entering the unsaturated zone is mobilizing additional PCE and quickly transporting it to the spring orifice. The PCE concentrations peaked within 24 to 48 hours after the initial decrease in specific conductance, suggesting that the source of PCE is relatively near the spring orifice and not at the more distal ends of the basin. Imes and others (1996) estimated that concentrations of PCE during base-flow conditions represent a discharge of about 3 gal of PCE per year. An additional $1 \mathrm{~kg}$ (about 0.2 gal) of PCE is discharged during each moderately large runoff event. Based on an average of 10 to 20 moderate to large events per year, between 5 and 10 gal of PCE are discharged from Shanghai Spring each year.

The source of PCE contamination at the spring remains unknown; however, based on results of dyetrace tests and the trends in PCE concentrations following runoff, FLW-002 is unlikely to be contributing substantially to the PCE contamination at Shanghai Spring. Possible sources include the former FLWMR laundry and dry cleaning facilities, existing or former dry cleaning facilities located off the FLWMR, and closed sanitary landfills (FLW-013, FLW-014, FLW015, and FLW-016) along Dry Creek (fig. 1). It is also possible that FLW-003, FLW-004, and FLW-005 are contributing to the PCE contamination at Shanghai Spring.

\section{SANITARY LANDFILLS}

Six of the SWMUs evaluated during this assessment (FLW-002, FLW-003, FLW-004, FLW-005, FLW-059, and FLW-060) are closed sanitary landfills. Because waste streams and degradation processes in 


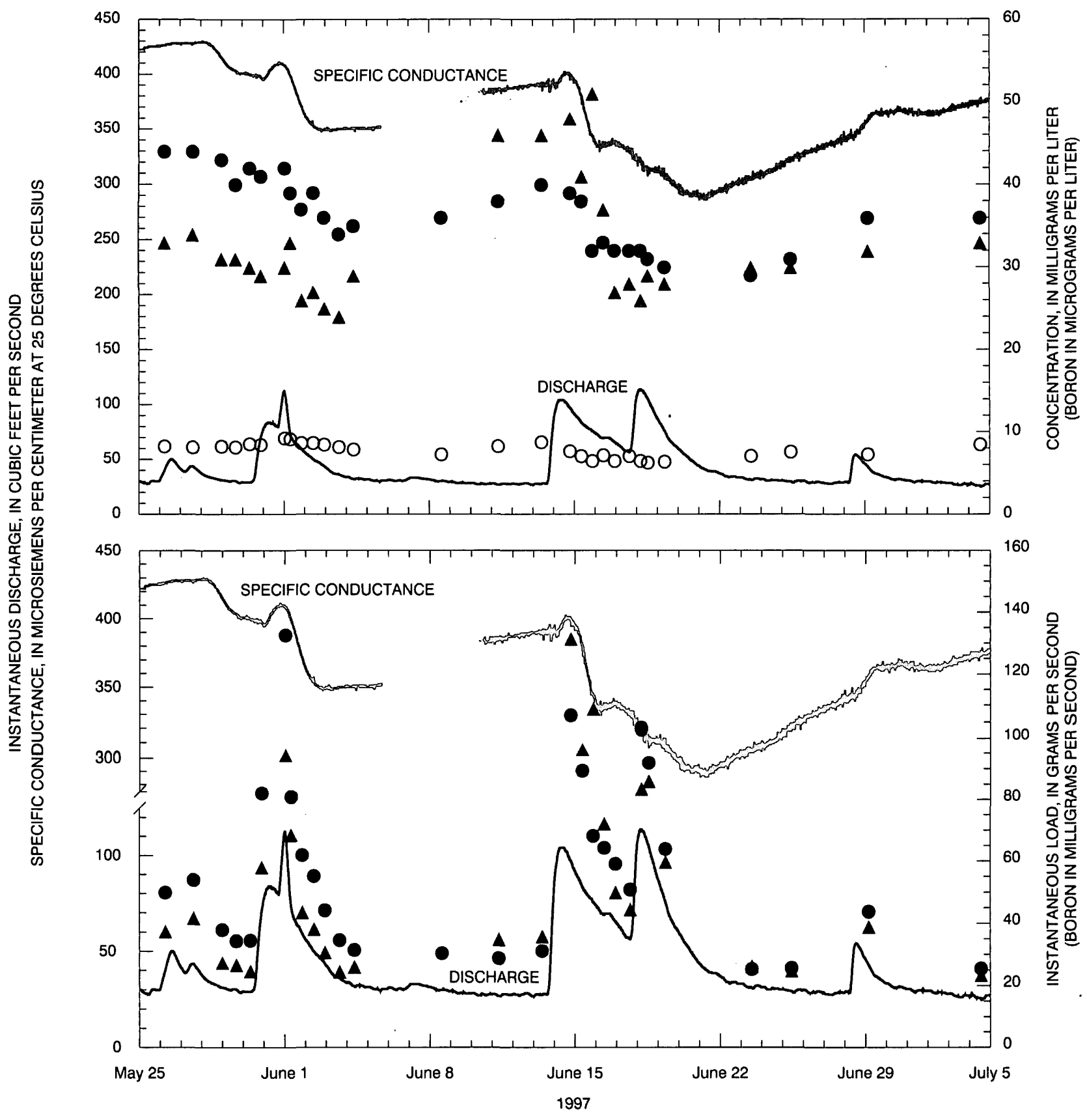

EXPLANATION

- calcium O CHLORIDE $\Delta$ BORON

Figure 12. Instantaneous discharge, specific conductance and concentrations and instantaneous loads of calcium, chloride, and boron in water samples from Shanghai Spring, May 25 through July 5, 1997. 
sanitary landfills are unique, these SWMUs were grouped for discussion. A preliminary reconnaissance of each SWMU was conducted during the spring and summer of 1995 . The reconnaissance included locating all potential leachate seeps, noting the general condition of the landfill cover, surveying a grid across each site to facilitate the collection of soil samples, and identifying tributaries or drainages that potentially could be affected by runoff from the sites. Following the reconnaissance, samples were collected during the summer of 1995 from soils and seeps at each site, and from existing shallow (less than $1.05 \mathrm{ft}$ deep) monitoring wells that contained water. Surface-water and streambed sediment samples also were collected from locations immediately downstream from each site. Based on results of the reconnaissance sampling, five additional deep monitoring wells (four to the regional water table) were installed and sampled at FLW-002 during 1997, and 10 deep monitoring wells were installed at FLW-003 and FLW-005 during 1998.

Large concentrations of inorganic constituents such as $\mathrm{Ca}, \mathrm{Na}, \mathrm{Cl}$, iron $(\mathrm{Fe}), \mathrm{SO}_{4}$, and ammonia as nitrogen $\left(\mathrm{NH}_{3}\right)$ are common in landfill leachate (Uhlman, 1989), in addition to $\mathrm{HCO}_{3}$ (Baedecker and Back, 1979). Acidic leachate seeping through the waste and earth materials below the landfill may cause some trace constituents to dissolve. Complexes with organic ligands also may increase trace constituent solubility. The most commonly detected organic compounds are chlorinated solvents, petroleum derived hydrocarbons, and pesticides (Borden and Yanoshak, 1990).

Schumacher and Hockanson (1996) used specific conductance and concentrations of $\mathrm{Na}$ or $\mathrm{Na}_{\mathrm{t}}$, alkalinity or $\mathrm{HCO}_{3}, \mathrm{Cl}, \mathrm{NH}_{3}$, barium or total barium (Ba or $\left.\mathrm{Ba}_{t}\right)$, boron $(\mathrm{B}), \mathrm{Fe}$ or total iron $\left(\mathrm{Fe}_{t}\right)$, strontium (Sr), and the presence of VOCs as indicators of landfill leachate. These physical properties, chemical constituents, and the presence of VOCs were used to identify effects of landfill leachate on ground- and surfacewater quality at the FLWMR. Values of physical properties and concentrations of inorganic constituents in samples from seeps and monitoring wells at sanitary landfills were compared to background values for ground water at the FLWMR estimated by Imes and others (1996). The background values are listed at the top of the appropriate data tables at the back of this report.

\section{Solid-Waste Management Unit FLW-002}

Solid-waste management unit FLW-002 is an abandoned sanitary landfill in the west-central part of the FLWMR about $2.5 \mathrm{mi}$ southwest of Forney Army Airfield and 0.5 mi west of road FLW 1 (fig. 2). The 34acre trench-type landfill was operated from 1981 to 1985. Until 1982, sludges from the furniture repair shop (methylene chloride), print shop (PCE and methylene chloride), PCE soaked filters from the FLWMR dry cleaning facility, pesticide rinseate, horse manure, and expired chemicals were placed in the landfill (U.S. Army Environmental Hygiene Agency, 1988a). Beginning in 1982, the industrial wastes and chemicals were disposed by the FLWMR Defense Reutilization Marketing Office (DRMO), pesticide rinsates were recycled with applied pesticides, and the horse manure was composted. These changes were introduced to decrease the environmental effect of waste disposal at the landfill.

The present landfill surface is irregular, but generally slopes toward a low-relief drainage that trends northeast across the northern part of the landfill (fig. 13). Water that accumulates in the drainage exits the landfill about $400 \mathrm{ft}$ west of the northeast corner of the landfill. The drainage is an unnamed, normally dry, tributary of Smith Branch, which flows northward about $0.5 \mathrm{mi}$ east of the landfill and eventually into Roubidoux Creek (fig. 2). The landfill has been covered with'soil and vegetation, and there is no exposed trash. Weathered bedrock of the Jefferson City Dolomite is exposed in a shallow excavation (probably a borrow pit) in the west-central part of the site. Vegetation generally is sparse, but is more dense along the northern and western boundaries of the landfill. Several seeps are present along the drainage in the central and northern parts of the landfill.

Five shallow (less than $30 \mathrm{ft}$ deep) monitoring wells (MW 001, MW 002, MW 004, MW 007, and MW 008) were installed in the overburden at FLW-002 during 1987 (U.S. Army Environmental Hygiene Agency, 1988b). Immediately after installation the wells were dry; however, 4 months later MW 001 and MW 002 contained a small amount of water and were sampled for specific conductance, $\mathrm{pH}$, selected anions $\left(\mathrm{Cl}, \mathrm{SO}_{4}, \mathrm{~F}\right.$, and $\left.\mathrm{NO}_{2 \mathrm{t}}+\mathrm{NO}_{3 \mathrm{t}}\right)$, trace elements, priority pollutant VOCs and SVs, pesticides, herbicides, and polychlorinated biphenyls (PCBs) (U.S. Army Environmental Hygiene Agency, 1988b). The sample from MW 001 had larger than background specific conductance $[840 \mu \mathrm{S} / \mathrm{cm}$ (microsiemens per centimeter at 25 


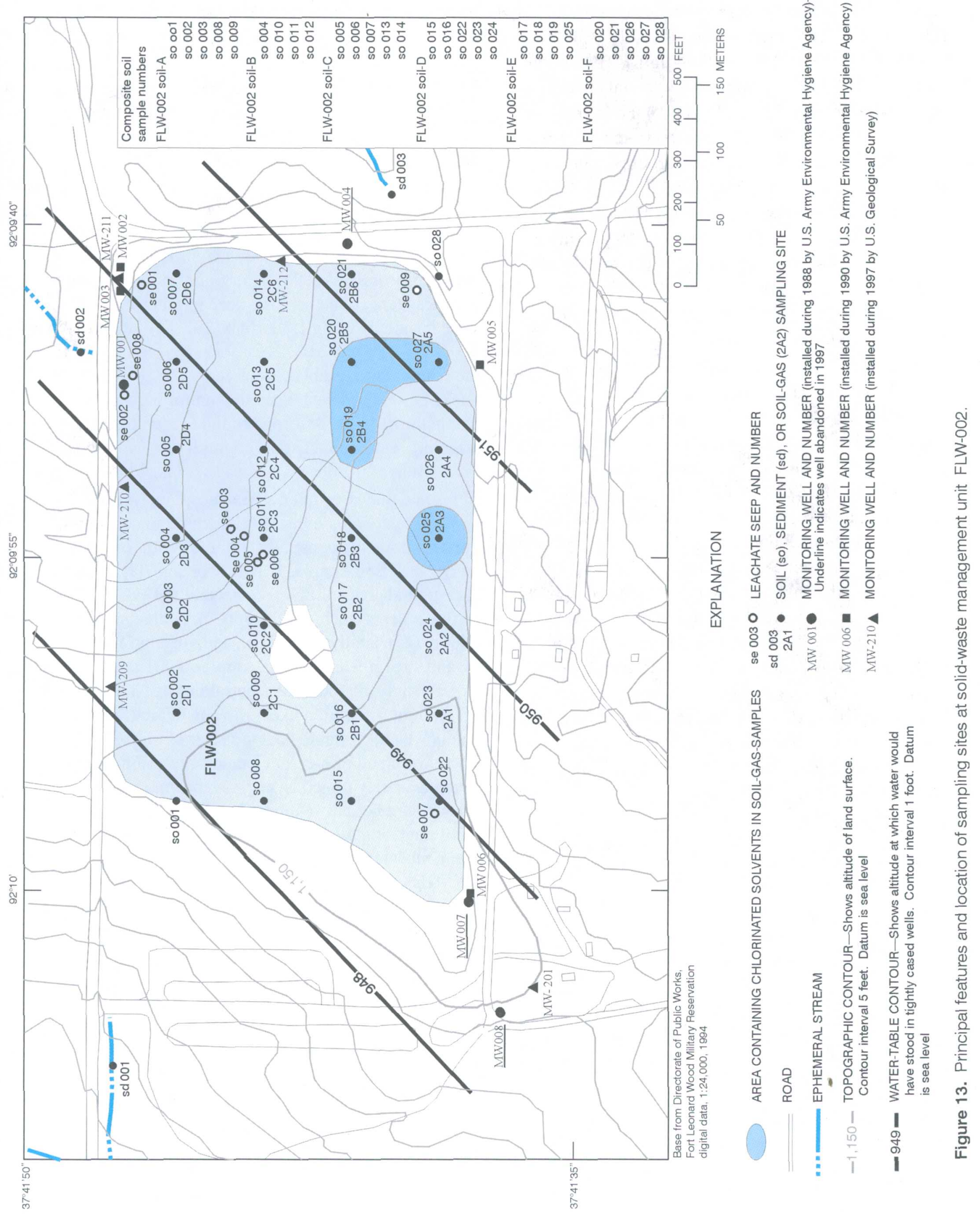


$\left.{ }^{\circ} \mathrm{C}\right)$ ] and larger than background concentrations of $\mathrm{Na}$ (28.2 mg/L), Cl (37 mg/L), total alkalinity $\left(\mathrm{Alk}_{\mathrm{t}}\right)$ (380 $\mathrm{mg} / \mathrm{L})$, and manganese $(\mathrm{Mn})(364 \mu \mathrm{g} / \mathrm{L})$. The sample from MW 002 had larger than background concentrations of $\mathrm{Na}(4.7 \mathrm{mg} / \mathrm{L}), \mathrm{Cl}(9.0 \mathrm{mg} / \mathrm{L}), \mathrm{Fe}(18,000$ $\mu \mathrm{g} / \mathrm{L})$, and $\mathrm{Mn}(4,890 \mu \mathrm{g} / \mathrm{L})$. A seep from an unspecified location in the north-central part of the site was identified and sampled during 1988 (U.S. Army Environmental Hygiene Agency, 1988b). The sample from this seep had specific conductance $(1,300 \mu \mathrm{S} / \mathrm{cm})$ and concentrations of $\mathrm{Na}(102 \mathrm{mg} / \mathrm{L}), \mathrm{Cl}(97 \mathrm{mg} / \mathrm{L}), \mathrm{Alk}_{\mathrm{t}}$ $(530 \mathrm{mg} / \mathrm{L}), \mathrm{Ba},(316 \mu \mathrm{g} / \mathrm{L}), \mathrm{Fe}(1,300 \mu \mathrm{g} / \mathrm{L}), \mathrm{Mn}(481$ $\mu \mathrm{g} / \mathrm{L})$, mercury $(\mathrm{Hg})(8.2 \mu \mathrm{g} / \mathrm{L})$, and selenium $(\mathrm{Se})(36$ $\mu \mathrm{g} / \mathrm{L})$ larger than background.

During 1990, three additional shallow monitoring wells (MW 003, MW 005, and MW 006) were installed in bedrock at depths ranging from $83 \mathrm{ft}$ (MW 003 and MW 005) to $100 \mathrm{ft}$ (MW 006). Depths to perched water in these wells ranged from 33 to $69 \mathrm{ft}$ below land surface during 1990 (U.S. Army Environmental Hygiene Agency, 1990). Water samples were collected from these monitoring wells during 1990 and analyzed for the same suite of analytes as the shallow wells, except the only trace elements analyzed for were silver (Ag), arsenic (As), Ba, cadmium (Cd), chromium $(\mathrm{Cr}), \mathrm{Hg}, \mathrm{Pb}$, and $\mathrm{Se}$. The samples generally contained background constituent concentrations, and no organic compounds were detected (U.S. Army Environmental Hygiene Agency, 1990). Although the water quality in the wells did not appear to be affected by landfill leachate, because of the placement of potentially hazardous materials in FLW-002, the final RCRA Facility Assessment Report concluded that the release of hazardous materials from FLW-002 to soils and ground water is likely (PRC Environmental Management, Inc., 1992).

A review of the records of the landfill operation indicates they are consistent with aerial photographs of the FLW-002 vicinity taken during 1971, 1986, and 1994. No development of the site was evident on the 1971 photograph that showed thick tree cover on the western two-thirds and spotty tree cover on the eastern one-third of the site. The landfill is evident on the 1986 and 1994 photographs with little discernible difference in the appearance of the landfill during this period. No discernible burial trenches were evident in the 1986 and 1994 photographs, and the land surface generally appeared smooth with no discernible brush or tree growth. A circular depression about $450 \mathrm{ft}$ in diameter, probably a borrow pit, is evident in the west-central part of the landfill.

The initial reconnaissance and sampling at FLW002 conducted during 1995 included the collection of 28 soil samples (combined into six composite samples) and 3 streambed sediment samples, the sampling of 4 of 9 potential leachate seeps, and the collection of samples from 6 of the existing monitoring wells (MW 004 and MW 008 were dry). The samples were analyzed for the suite of constituents listed in table 2. Tributaries in the vicinity of FLW-002 were dry, and no surface-water samples were collected. Five deep monitoring wells were installed during 1997 (MW-201, MW-209, MW210, MW-211, and MW-212); four were completed to the regional water table (about 165 to $200 \mathrm{ft}$ deep) and one (MW-211) was intended to monitor perched water within the bedrock. A second round of monitoring well sampling was conducted during mid-1997 after the installation of the deep wells was completed.

Soil and streambed sediment samples from FLW-002 generally contained background concentrations of inorganic constituents (table 6, at the back of this report). Soil samples B and D contained larger than background concentrations of several trace or rareearth elements, such as cerium (Ce), lanthanum (La), lithium ( $\mathrm{Li})$, neodymium (Nd), and yttrium (Y) (table 6), and streambed sediment sample sd 001 contained larger than background concentrations of $\mathrm{Al}, \mathrm{Fe}, \mathrm{Ce}$, $\mathrm{Cr}$, gallium (Ga), Li, nickel (Ni), scandium (Sc), vanadium (V), and Y (table 7, at the back of this report). These trace and rare-earth elements are common constituents in clay minerals, and the concentrations detected are not unusual based on the relatively large percentage of clay-size material in soil and streambed sediment samples from this site as compared to other SWMUs (figs. 14, 15). Streambed sediment sample sd 002 contained sufficient material in the nonmagnetic heavy-mineral concentrate for optical mineralogic analyses that detected primarily dolomite, $\mathrm{Fe}$ and $\mathrm{Mn}$ oxides, minor rutile, zircon, tourmaline, and barite. The sample also contained several grains of elemental $\mathrm{Pb}$ and brass, indicating probable contamination from spent small arms munitions.

Streambed sediment samples from FLW-002 contained detectable concentrations of organochlorine pesticides such as chlordane (less than 1 to $2.6 \mu \mathrm{g} / \mathrm{kg}$ ), DDT $(0.13$ to $28 \mu \mathrm{g} / \mathrm{kg}$ ), DDD (less than 0.1 to 4.4 $\mu \mathrm{g} / \mathrm{kg}$ ), DDE ( 0.14 to $48 \mu \mathrm{g} / \mathrm{kg}$ ), dieldrin (less than 0.1 to $0.36 \mu \mathrm{g} / \mathrm{kg}$ ), and gross PCBs (1.7 to $14 \mu \mathrm{g} / \mathrm{kg}$ ) (table 

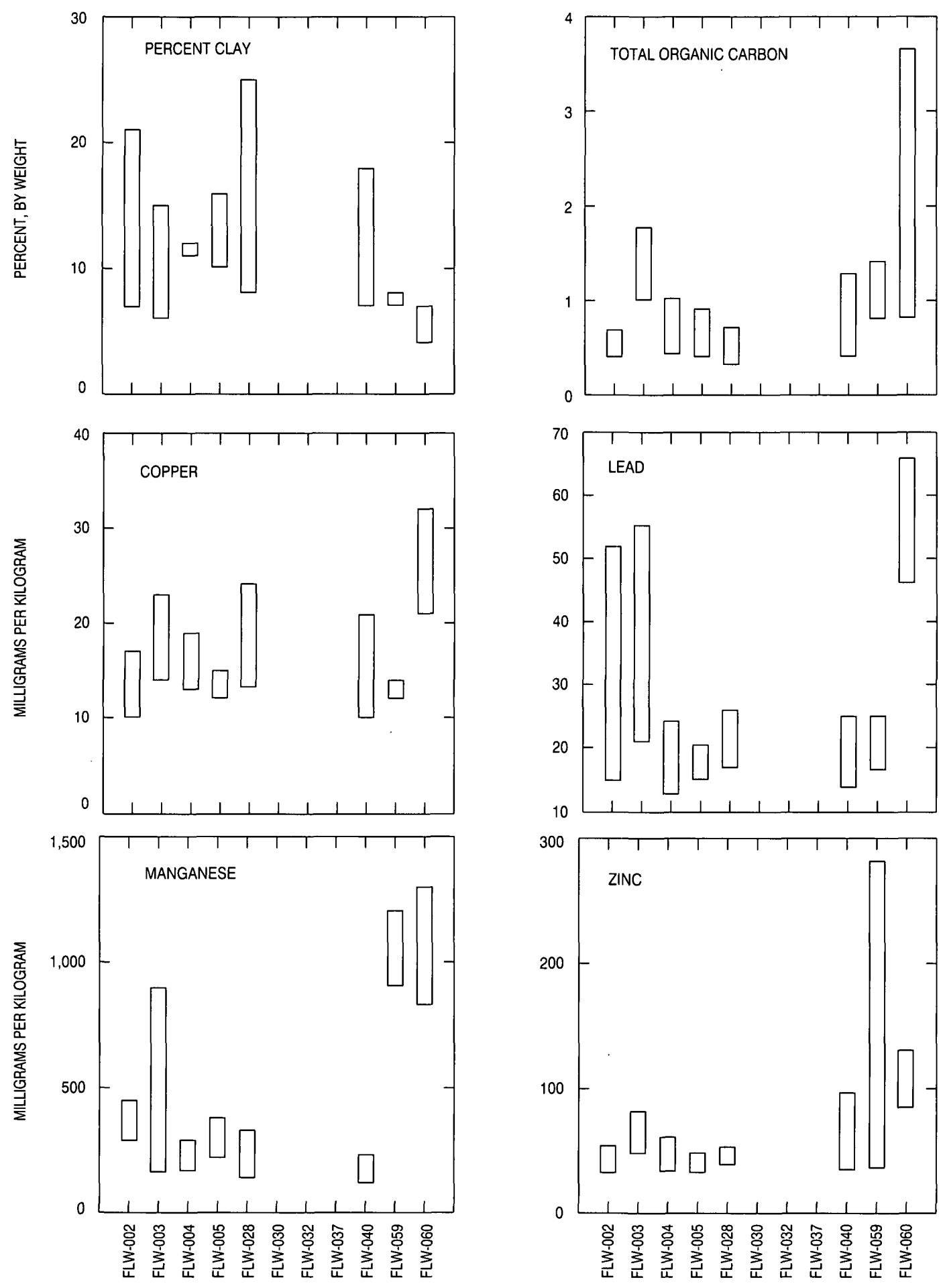

SOLID-WASTE MANAGEMENT UNIT

Figure 14. Range of percent clay, percent total organic carbon, and selected trace-element concentrations in soil samples from solid-waste management units. 

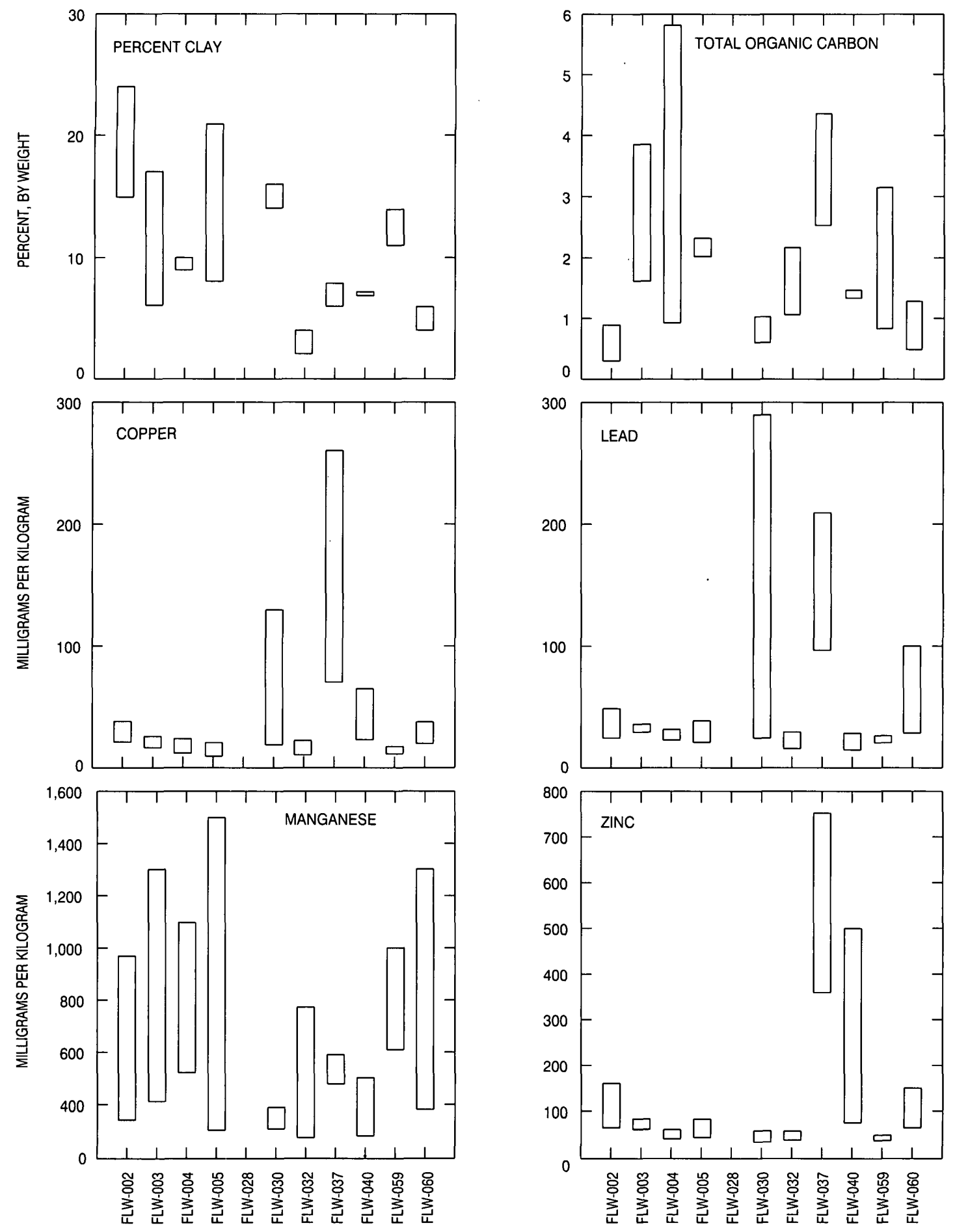

SOLID-WASTE MANAGEMENT UNIT

Figure 15. Range of percent clay, percent total organic carbon, and selected trace-element concentrations in streambed sediment samples from solid-waste management units. 
8, at the back of this report). Except for samples from the vicinity of FLW-037 (the old pesticide storage building), DDD concentrations at FLW-002 were among the largest detected in streambed sediment samples at the FLWMR and possibly were the result of pesticide rinseate being disposed at this site (U.S. Army Environmental Hygiene Agency, 1988a).

Analysis of soil-gas samples from FLW-002 using a portable GC indicated the presence of measurable quantities of BTEX, numerous unidentified VOCs, and chlorinated solvents such as PCE, trichloroethene (TCE), cis-1,2-Dichloroethene (cis-DCE), and vinyl chloride (VC). After spring rains, pockets of methane $\left(\mathrm{CH}_{4}\right)$ gas (presence confirmed using an explosive-gas meter) were observed bubbling from the landfill surface in the vicinity of soil-gas samplers $2 \mathrm{C} 5$, 2C6, and 2D5 (fig. 13). During 1997, soil-gas samples were collected from 23 soil-gas samplers and analyzed using the portable GC. Soil-gas samplers 2A2, 2A3, $2 \mathrm{C} 2$, and $2 \mathrm{C} 6$ contained detectable concentrations of BTEX and other VOCs. The field GC scans also identified PCE, TCE, or cis-DCE in soil-gas samplers $2 \mathrm{~A} 3$, $2 \mathrm{~A} 5,2 \mathrm{~B} 4$, and $2 \mathrm{~B} 5$ in the southeastern part of the site (fig. 13). The portable GC could not resolve $\mathrm{VC}$, and, because no air standards were available for PCE, TCE, or cis-DCE, the concentrations were estimated from aqueous standards using dimensionless air/water parti- tioning coefficients calculated from Henry's Law coefficients assuming a pressure of 1 atmosphere and temperature of $20^{\circ} \mathrm{C}$.

To confirm the results of the portable GC, soilgas samples were collected from samplers $2 \mathrm{~A} 2,2 \mathrm{~A} 3$, $2 \mathrm{~B} 4$, and $2 \mathrm{C} 2$ several months later using a metering pump and sorption cartridges and submitted to the Oregon Graduate Institute for GC-MS analyses. Although indicating smaller concentrations, the results of the laboratory GC-MS analyses generally confirmed the field GC scans, detecting PCE at $7 \mathrm{ppb}$ (parts per billion) and TCE at 9 and $3 \mathrm{ppb}$ in samples from 2A3 and 2B4 (table 9). The GC-MS also detected moderately large concentrations of cis-DCE and VC in the samples from $2 \mathrm{~A} 3$ (330 and $250 \mathrm{ppb}$ ) and 2B4 (120 and $273 \mathrm{ppb}$ ).

Because the concentrations exceeded the instrument calibration, all GC-MS concentrations were reported as estimated concentrations. The considerable range in estimated concentrations detected by the field GC scan and laboratory GC-MS analyses results from the difficulty in maintaining adequate flow rates through the sorption tubes submitted for laboratory analyses, lack of air standards for the field GC scan, and considerable time interval between the two sets of samples. However, the field GC scans and laboratory GC-MS analyses suggests the presence PCE and TCE wastes in the southeastern part of FLW-002 (fig. 13).

Table 9. Estimated concentrations of chlorinated solvents in soil-gas samples from solid-waste management unit FLW-002 [All concentrations are in parts per billion; GC, gas chromatograph; GC-MS, gas chromatography-mass spectroscopy; nd, not detected; $<$, less than; nt, not tested]

\begin{tabular}{|c|c|c|c|c|c|c|c|}
\hline \multirow[b]{2}{*}{$\begin{array}{l}\text { Solrgas } \\
\text { sampler } \\
\text { number }\end{array}$} & \multicolumn{2}{|c|}{$\begin{array}{l}\text { Tetrachloroethene } \\
\text { (PCE) }\end{array}$} & \multicolumn{2}{|c|}{$\begin{array}{l}\text { Trichloroethene } \\
\text { (TCE) }\end{array}$} & \multicolumn{2}{|c|}{$\begin{array}{l}\text { cls-1,2-Dichloroethene } \\
\text { (cls-DCE) }\end{array}$} & \multirow{2}{*}{$\begin{array}{c}\begin{array}{c}\text { Vinyl chlorlde } \\
\text { (VC) }\end{array} \\
\begin{array}{c}\text { Laboratory } \\
\text { (GC-MS) } \\
03 / 04 / 98\end{array}\end{array}$} \\
\hline & $\begin{array}{c}\text { Fleld scan } \\
\text { (portable GC) } \\
07 / 09 / 97\end{array}$ & $\begin{array}{l}\text { Laboratory } \\
\text { (GC-MS) } \\
\text { 03/04/98 }\end{array}$ & $\begin{array}{l}\text { Field scan } \\
\text { (portable GC) } \\
07 / 09 / 97\end{array}$ & $\begin{array}{l}\text { Laboratory } \\
\text { (GC-MS) } \\
03 / 04 / 98\end{array}$ & $\begin{array}{c}\text { Field scan } \\
\text { (portable GC) } \\
07 / 09 / 97\end{array}$ & $\begin{array}{l}\text { Laboratory } \\
\text { (GC-MS) } \\
\text { 03/04/98 }\end{array}$ & \\
\hline $2 \mathrm{~A} 2$ & nd & $<0.2$ & nd & $<0.2$ & nd & 0.1 & 0.1 \\
\hline $2 \mathrm{~A} 3$ & 390 & 7 & 290 & 9 & 28,000 & 330 & 250 \\
\hline $2 \mathrm{AS}$ & 340 & $\mathrm{nt}$ & nd & $\mathrm{nt}$ & 19 & nt & $\mathrm{nt}$ \\
\hline $2 \mathrm{~B} 4$ & 700 & 7 & 6 & 3 & 106 & 120 & 273 \\
\hline 2B5 & 160 & $\mathrm{nt}$ & nd & $\mathrm{nt}$ & 19 & $\mathrm{nt}$ & $\mathrm{nt}$ \\
\hline $2 \mathrm{C} 2$ & nd & $<.2$ & nd & $<.2$ & nd & $<2$ & $<.2$ \\
\hline
\end{tabular}

Between 5 and $21 \mathrm{ft}$ of overburden is present at FLW-002 (table 3); it consists of gravelly clay and silty clay. Geologic logs constructed from air-rotary drill cuttings during the installation of deep bedrock monitoring wells at the site during 1997 indicate that the uppermost bedrock unit at the site is the Jefferson City Dolomite. The unit ranges from $8 \mathrm{ft}$ thick in monitoring well MW-210 to $44 \mathrm{ft}$ thick in monitoring well MW201. The unit consists of light gray, cherty, fine-grained dolostone that is medium to thickly bedded with occasional sand and thin beds of greenish mudstone or shale. Bit drop and loss of drill water circulation, indicative of a void or solution cavity, were encountered in borehole MW-201 near the base of the Jefferson City 
Dolomite between depths of 49 and $59 \mathrm{ft}$. The underlying Roubidoux Formation ranges from 166 to $178 \mathrm{ft}$ thick at FLW-002. The formation consists primarily of sandy and cherty dolostone with interbedded sandstone and occasional siltstone and mudstone beds. Distinct beds of white, poorly cemented, well-sorted finegrained quartz sand were encountered in boreholes MW-201 (69 to $74 \mathrm{ft}$ deep), MW-209 (100 to $110 \mathrm{ft}$ deep and 185 to $190 \mathrm{ft}$ deep), MW-210 (79 to $88 \mathrm{ft}$ deep), MW-211 (72 to $83 \mathrm{ft}$ deep), and MW-212 (79 to $93 \mathrm{ft}$ deep). During the drilling of borehole MW-212, numerous voids, some clay filled, were encountered within the Roubidoux Formation at depths between 105 and $160 \mathrm{ft}$. Boreholes MW-201, MW-209, MW210 , and MW-212 were advanced beneath the Roubidoux Formation into the underlying massive, nearly chert-free upper Gasconade Dolomite. The regional water table beneath FLW-002 is more than $170 \mathrm{ft}$ below the land surface. Monitoring wells in these boreholes were completed so that the open interval (filter pack) was about 5 to $10 \mathrm{ft}$ below the regional water table and straddled the contact between the Roubidoux Formation and underlying Gasconade Dolomite. Monitoring well MW-211 was completed above the regional water table to monitor perched water encountered while drilling.

There are at least three zones of perched water above the regional water table at FLW-002. Water levels (measured from the top of the well casing) in monitoring wells MW 001 and MW 002 ranged from 8.86 and $10.07 \mathrm{ft}$ and indicate locally saturated conditions within the overburden. Several leachate seeps also were observed near MW 001, confirming the presence of shallow saturated conditions in this area. Saturated overburden also was encountered during the drilling of borehole MW-210. Return water from the overburden in this borehole ( 0 to $13 \mathrm{ft}$ deep) had a large specific conductance (greater than $1,100 \mu \mathrm{S} / \mathrm{cm}$ ) and $\mathrm{Cl}$ concentration $(100 \mathrm{mg} / \mathrm{L}$, determined using a portable spectrophotometer) indicating the presence of landfill leachate, and a permanent surface casing was installed to a depth of $19 \mathrm{ft}$ to prevent downhole contamination. Two zones of perched water were identified within the Roubidoux Formation. Saturated conditions were encountered in borehole MW-211 at depths between about 90 and $120 \mathrm{ft}$ deep. Return water from this interval was orangish and contained $\mathrm{Cl}$ concentrations greater than $20 \mathrm{mg} / \mathrm{L}$ (determined using a portable spectrophotometer), indicating effects from landfill leachate (drill water contained less than $5 \mathrm{mg} / \mathrm{L} \mathrm{Cl}$ ).
Monitoring well MW-211 was completed at a relatively shallow depth (open interval from 100 to $124 \mathrm{ft}$ deep) to monitor this perched zone. However, after installation of the annular seal, the water level in MW-211 slowly dropped until the well went dry 2 days later. A deep zone (166 ft deep) of perched water within the Roubidoux Formation was encountered during the drilling of borehole MW-209. Return water from this interval also was orangish and had an elevated specific conductance $(930 \mu \mathrm{S} / \mathrm{cm})$ and $\mathrm{Cl}$ concentration (50 $\mathrm{mg} / \mathrm{L}$, determined using a portable spectrophotometer), indicating effects from landfill leachate.

Although the regional water-table map (fig. 2) indicates shallow ground-water flow in the vicinity of FLW-002 is toward the north or northeast, water levels from the bedrock monitoring wells indicate that local ground-water flow beneath FLW-002 is to the northwest (fig. 13). This local configuration of the water table may be caused by leakage from Bloodland Lake recharging ground water about $0.5 \mathrm{mi}$ southeast of FLW-002 (fig. 2). Although MW-201 was intended to be an upgradient monitoring point, based on the watertable contours in figure 13, none of the deep wells installed during 1997 are clearly upgradient of FLW002.

Analyses of water samples collected during 1995 indicate that seeps se 002, se 003, se 008, and se 009 have been affected by landfill leachate. Samples from seeps se 002 , se 003 , and se 008 plot outside the range of background ground-water concentrations on a trilinear diagram (fig. 16) and had specific conductance values and concentrations of indicator constituents $(\mathrm{Na}$, $\mathrm{Cl}, \mathrm{HCO}_{3}, \mathrm{NH}_{3 \mathrm{t}}, \mathrm{Ba}, \mathrm{B}, \mathrm{Fe}$, and $\mathrm{Sr}$ ) and most dissolved and total major ions, nutrients, and trace elements substantially larger than background (table 10, at the back of this report). Samples from seep se 009 were not plotted because of missing $\mathrm{HCO}_{3}$ data. Samples from se 002 and se 009 tended to have among the largest concentrations of most inorganic constituents, with concentrations of $\mathrm{Na}(120$ and $230 \mathrm{mg} / \mathrm{L})$, potassium $(\mathrm{K})$ (73 and $21 \mathrm{mg} / \mathrm{L}$ ), $\mathrm{Cl}$ (93 and $370 \mathrm{mg} / \mathrm{L}), \mathrm{NH}_{3 \mathrm{t}}(18$ $\mathrm{mg} / \mathrm{L}), \mathrm{B}(1,600$ and $420 \mu \mathrm{g} / \mathrm{L})$, and $\mathrm{Mn}$ (580 and 370 $\mu \mathrm{g} / \mathrm{L}$ ) more than 20 times the respective background values for ground water at the FLWMR (table 10). Concentrations of $\mathrm{Fe}_{\mathrm{t}}$ and total manganese $\left(\mathrm{Mn}_{\mathrm{t}}\right)$ in all seep samples exceeded the Missouri Ground Water Standard of 300 and $50 \mu \mathrm{g} / \mathrm{L}$, respectively (table 10 ) (Missouri Department of Natural Resources, 1996b). Large concentrations of VOCs ( 12.9 to $124 \mu \mathrm{g} / \mathrm{L}$ total VOCs) were detected in the seep samples, with the 


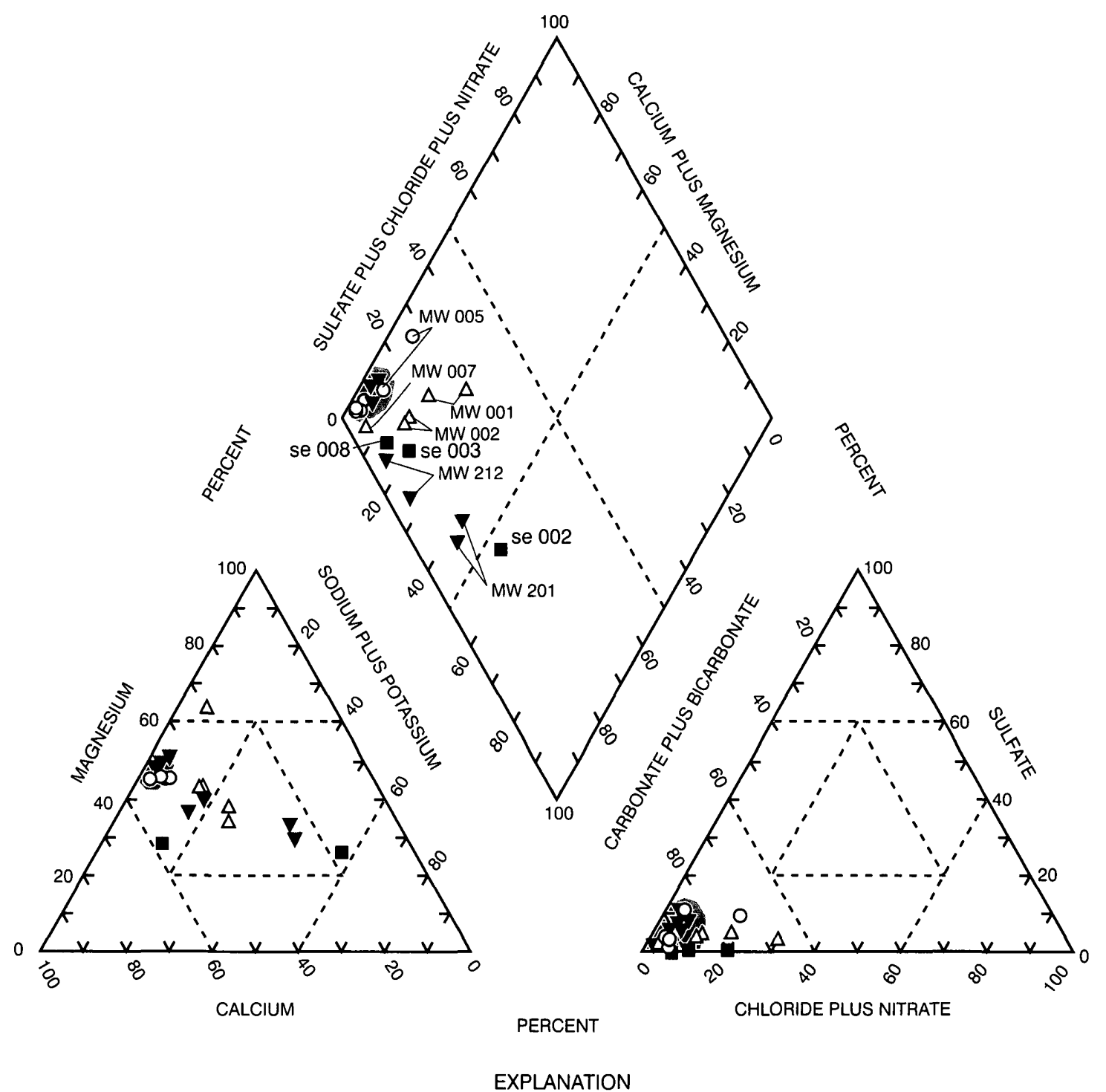

SHADED AREA REPRESENTS THE RANGE OF BACKGROUND CHEMICAL COMPOSITION OF GROUND WATER FROM THE FORT LEONARD WOOD MILITARY RESERVATION AND VICINITY AS MEASURED BY IMES AND OTHERS (1996)

- SEEP

$\Delta$ OVERBURDEN WELL

O SHALLOW BEDROCK WELL

$\nabla$ DEEP BEDROCK WELL

Figure 16. Trilinear diagram depicting molar equivalents of major ions in ground-water samples from solid-waste management unit FLW-002. 
largest concentrations in samples from se 003 and se 009 (86 and $124 \mu \mathrm{g} / \mathrm{L}$ ) (table 11, at the back of this report). The predominant VOCs detected were xylenes (less than 0.2 to $28 \mu \mathrm{g} / \mathrm{L}$ ), acetone (less than 5 to 32 $\mu \mathrm{g} / \mathrm{L}$ ), and ethylether (less than 0.2 to $50 \mu \mathrm{g} / \mathrm{L}$ ). The sample from se 009 also contained more than 30 nontarget VOCs that were mainly substituted benzenes or napthalenes, indicating a fuel-related source. Despite the documented placement of solvent wastes in FLW002 , none of the seep samples contained detectable concentrations of chlorinated solvents such as PCE, TCE, or their decomposition products. Samples from se 008 contained detectable concentrations of freons (not listed in table 11), such as chlorofluoromethane (freon 31 ) (4.3 and $4.4 \mu \mathrm{g} / \mathrm{L}$ ) and chlorodifluoromethane (freon 22$)(7.4$ and $7.7 \mu \mathrm{g} / \mathrm{L})$. Only the sample from se 002 contained sufficient volume for the analysis of pesticides, none of which were detected.

Samples from shallow overburden monitoring wells MW 001, MW 002, and MW 007 plot outside the background range on the trilinear diagram and also appear to be affected by landfill leachate (fig. 16). Samples from MW 001 and MW 007 contained larger than background values of many inorganic constituents (table 10). Although samples from MW 002 plot outside the background range on figure 16 , they had small specific conductance values (184 and $213 \mu \mathrm{S} / \mathrm{cm}$ ), and, except for $\mathrm{Fe}_{\mathrm{t}}(3,000$ and $5,300 \mu \mathrm{g} / \mathrm{L})$ and $\mathrm{Mn}_{\mathrm{t}}(3,100$ and $4,400 \mu \mathrm{g} / \mathrm{L}$ ), generally concentrations of inorganic constituents similar to background. This well probably is affected by landfill leachate to a lesser degree than MW 001 and MW 007. Concentrations of $\mathrm{Fe}_{\mathrm{t}}(3,000$ to $87,000 \mu \mathrm{g} / \mathrm{L})$ and $\mathrm{Mn}_{\mathrm{t}}(780$ to $16,000 \mu \mathrm{g} / \mathrm{L})$ in samples from MW 001, MW 002, and MW 007 exceeded the Missouri Ground Water Standard of $300 \mu \mathrm{g} / \mathrm{L}$ and 50 $\mu \mathrm{g} / \mathrm{L}$, respectively (Missouri Department of Natural Resources, 1996b). Concentrations of total lead $\left(\mathrm{Pb}_{t}\right)$ (30 and $140 \mu \mathrm{g} / \mathrm{L}$ ) in samples from monitoring wells MW 005 and MW 007 also exceeded the Missouri Ground Water Standard of $15 \mu \mathrm{g} / \mathrm{L}$. Samples from all three monitoring wells contained detectable concentrations of VOCs with the largest concentrations (more than $60 \mu \mathrm{g} / \mathrm{L}$ total VOCs) detected in the May 14,1997 , sample from MW 001 (table 11). The most prevalent VOC detected in samples from MW 001 and MW 002 was ethylether (less than 0.2 to $42 \mu \mathrm{g} / \mathrm{L}$ ). Unlike seep samples, samples from MW 001 and MW 002 contained detectable concentrations of $\mathrm{VC}(0.1$ to 13.6 $\mu \mathrm{g} / \mathrm{L}$ ) and cis-DCE (less than 0.2 to $0.5 \mu \mathrm{g} / \mathrm{L}$ ) - two known microbial degradation products of chlorinated solvents such as TCE and PCE. The concentration of $\mathrm{VC}$ in the May 1997 sample from MW $001(13.6 \mu \mathrm{g} / \mathrm{L})$ exceeded the Missouri Ground Water Standard of 2 $\mu \mathrm{g} / \mathrm{L}$ (Missouri Department of Natural Resources, 1996b). No concentrations of pesticides or organochlorine pesticides were detected in samples from the overburden wells; however, the pesticide sample collected from MW 001 was broken in shipment.

Samples from shallow bedrock monitoring wells MW 003, MW 005, and MW 006 contained larger than background concentrations of inorganic constituents or detectable concentrations of chlorinated solvents, indicating landfill leachate has affected the quality of perched water within the bedrock. Samples from MW 003 generally contained concentrations of inorganic constituents that were within the background range on the trilinear diagram (fig. 16). Despite plotting within the background range on the trilinear diagram, samples from MW 006 had specific conductance values (628 to $644 \mu \mathrm{S} / \mathrm{cm}$ ) and concentrations of several major constituents, including $\mathrm{Cl}$ and $\mathrm{HCO}_{3}$, larger than background (table 10). Samples from all three shallow bedrock wells contained detectable concentrations of VOCs, including chlorinated solvents, with the largest concentrations ( $4.7 \mu \mathrm{g} / \mathrm{L} \mathrm{PCE}$ and $26 \mu \mathrm{g} / \mathrm{L}$ acetone) detected in the May 1995 sample from MW 005. Samples from MW 003 contained TCE $(0.13$ and 0.18 $\mu \mathrm{g} / \mathrm{L})$ and samples from MW 006 contained PCE $(0.14$ $\mu \mathrm{g} / \mathrm{L}$ ). Small concentrations of VC (less than 0.2 to 0.8 $\mu \mathrm{g} / \mathrm{L}$ ) were detected in samples from MW 003 and MW 005 (table 11). None of the samples from the shallow bedrock wells contained detectable concentrations of pesticides.

Samples from deep bedrock monitoring wells MW-201 and MW-212 indicate that landfill leachate from FLW-002 has migrated to the regional water table. Samples from MW-201 contained larger than background concentrations of most major and several trace constituents such as $\mathrm{Na}, \mathrm{Na}_{\mathfrak{t}}, \mathrm{Cl}, \mathrm{SO}_{4}, \mathrm{~F}, \mathrm{P}_{\mathfrak{t}}, \mathrm{B}, \mathrm{B}_{\mathfrak{t}}, \mathrm{Mn}$, $\mathrm{Mn}_{\mathrm{t}}$, and Sr. Samples from MW-212 contained larger than background concentrations of $\mathrm{Na}, \mathrm{Na}_{\mathrm{t}}, \mathrm{Cl}, \mathrm{HCO}_{3}$, $\mathrm{P}_{\mathrm{t}}, \mathrm{Mn}, \mathrm{Mn}_{\mathrm{t}}$, and $\mathrm{Sr}$ (table 10). Concentrations of $\mathrm{Mn}_{\mathrm{t}}$ in samples from MW-201 (120 and $280 \mu \mathrm{g} / \mathrm{L})$ and MW-212 (61 and $65 \mu \mathrm{g} / \mathrm{L})$ were larger than the Missouri Ground Water Standard of $50 \mu \mathrm{g} / \mathrm{L}$ (Missouri Department of Natural Resources, 1996b). Although boreholes MW-209 and MW-210 are downgradient from FLW-002 and encountered landfill leachate within the overburden or perched water within the bed- 
rock, samples from these monitoring wells generally contained concentrations of inorganic constituents similar to background.

Molar ratios of $\mathrm{Na} / \mathrm{Cl}$ in samples from monitoring wells MW-201 (5.8 and 7.4) and MW-212 (6.1 and 8.6) were unusually large compared to molar $\mathrm{Na} / \mathrm{Cl}$ ratios from other wells at the site (generally less than 2) or regional ground water at the FLWMR (less than 3). In addition, samples from MW-201 had relatively small concentrations of $\mathrm{Ca}(31$ and $33 \mathrm{mg} / \mathrm{L})$ and $\mathrm{Mg}(21$ and $26 \mathrm{mg} / \mathrm{L}$ )-compared to other wells at the site (table 10) or regional ground water (Imes and others, 1996).

Schumacher and Hockanson (1996) observed a similar pattern of small $\mathrm{Ca}$ and $\mathrm{Mg}$ concentrations and large $\mathrm{Na}$ concentrations in water samples collected from a newly installed monitoring well at a sanitary landfill in southeastern Missouri. They attributed these concentrations to the exchange of $\mathrm{Ca}$ and $\mathrm{Mg}$ for $\mathrm{Na}$ by the Na-rich bentonite grout used to seal the borehole annulus. The geochemical code PHREEQC (Parkhurst, 1995) was used to determine if a similar process was affecting concentrations of major cations in samples from monitoring wells MW-201 and MW-212. The exchange of $\mathrm{Ca}$ and $\mathrm{Mg}$ for $\mathrm{Na}$ was simulated according to the reaction:

$$
\begin{gathered}
\left(\mathrm{Ca}_{0.75}{ }^{2+}, \mathrm{Mg}_{0.25}{ }^{2+}\right)+\left[2 \mathrm{Na}^{+} \text {-solid }\right]= \\
{\left[\mathrm{Ca}_{0.75}{ }^{2+}, \mathrm{Mg}_{0.25}{ }^{2+} \text {-solid }\right]+2 \mathrm{Na}^{+} .}
\end{gathered}
$$

The reverse reaction was added in incremental steps until the $\mathrm{Ca}$ concentrations exceeded background $(68 \mathrm{mg} / \mathrm{L})$ or the $\mathrm{Na}$ concentrations decreased to less than $2 \mathrm{mg} / \mathrm{L}$. Results of the simulations yielded calculated concentrations of $\mathrm{Ca}$ ( 66 and $68 \mathrm{mg} / \mathrm{L}), \mathrm{Mg}(26$ and $31 \mathrm{mg} / \mathrm{L})$, and $\mathrm{Na}(7$ and $9 \mathrm{mg} / \mathrm{L})$ and molar $\mathrm{Na} / \mathrm{Cl}$ ratios (0.96 and 0.91) in samples from MW-201 that were generally comparable to the expected background ranges. Simulations using the July 1997 sample from MW-212 (simulation limited by the initial Na concentration) resulted in calculated concentrations of $\mathrm{Ca}(62$ and $65 \mathrm{mg} / \mathrm{L}), \mathrm{Mg}(28 \mathrm{mg} / \mathrm{L})$, and $\mathrm{Na}$ (14 and $2 \mathrm{mg} / \mathrm{L}$ ) and molar $\mathrm{Na} / \mathrm{Cl}$ ratios (4.4 and 0.5$)$ that also approached background. The above exchange reaction, however, cannot account for all of the excess $\mathrm{Na}$ measured in the April 1997 sample from monitoring well MW-212. The simulations are not unique, but do suggest that, in addition to being affected by landfill leachate, the major cation concentrations in samples from MW-201 and MW-212 also may be affected by cation-exchange reactions involving the $\mathrm{Na}$-bentonite used to seal the borehole annulus.
In addition to larger than background concentrations of inorganic constituents, samples from monitoring well MW-212 also contained detectable concentrations of the chlorinated solvents $\mathrm{PCE}(0.7$ and $1.6 \mu \mathrm{g} / \mathrm{L}), \mathrm{TCE}(0.4$ and $1.1 \mu \mathrm{g} / \mathrm{L})$, cis-DCE (less than 0.2 and $0.7 \mu \mathrm{g} / \mathrm{L}$ ), $\mathrm{VC}$ (less than or equal to $0.2 \mu \mathrm{g} / \mathrm{L}$ ), and a variety of other VOCs (table 11). The detection of chlorinated solvents in samples from MW-212 is consistent with the soil-gas data that indicated the presence of these compounds in the southeastern part of FLW-002 near MW-212. Small concentrations of acetone, chloroform, and methylene chloride were detected in samples from MW-201. No VOCs were detected in samples from monitoring wells MW-209 or MW-210.

Results of seep and monitoring well sampling at FLW-002 indicate that leachate from the landfill has migrated through the unsaturated zone to the regional water table. Seep samples generally contained the largest concentrations of inorganic constituents, especially total inorganic constituents and non-chlorinated VOCs. Concentrations of inorganic constituents and VOCs were variable in the overburden and shallow bedrock wells but generally smaller than those concentrations in the seep samples. The large frequency of total inorganic constituents detected above background is probably caused by suspended solids in the water samples. Samples from the seeps and shallow wells had varied turbidity and the use of bailers to sample the overburden and shallow bedrock wells enhanced the likelihood of entraining fine particulates in the water samples. The detection of PCE and TCE and their degradation products in soil-gas samples, samples from the overburden, shallow bedrock, and deep bedrock monitoring wells, despite their absence in seep samples, indicates that seep samples are not reliable indicators of the distribution of VOCs within or migrating from the landfill. The absence of landfill leachate effects in samples from downgradient monitoring wells MW-209 and MW-210 and apparent effects in monitoring wells MW-201 and MW-212 indicates a complex mechanism of leachate migration from FLW-002 to the regional water table. Much of the complexity probably is related to the heterogeneous lithology of the Roubidoux Formation, orientation of bedding planes, presence of fractures and solution features within the bedrock, and relatively thick unsaturated zone.

Contaminants in the saturated zone at FLW-002 probably will migrate toward the north or northwest for a relatively short distance before assuming a more 
regional northeasterly flow direction (fig. 2). Although dye injected into Smith Branch about 0.5 mi northeast of FLW-002 emerged at Miller Spring (fig. 5), FLW002 is located near the divide between the Shanghai Spring and Miller Spring Basins and contaminants entering the ground water in this area could possibly migrate toward either spring. Because of the large volumes of water discharged by these springs and the location of FLW-002 near the distal end of both spring basins, contaminants migrating from FLW-002 probably would be diluted to less than detection before reaching either spring orifice.

\section{Solid-Waste Management Unit FLW-003}

Solid-waste management unit FLW-003 is a 17acre landfill in the central part of the FLWMR southeast of Forney Army Airfield and about $800 \mathrm{ft}$ east of road FLW 1 (fig. 2). This trench-type landfill was operated between 1968 and 1978 as a disposal site for household garbage (U.S. Army Environmental Hygiene Agency, 1988a). According to the USAEHA, sludges from unspecified sources also were placed in FLW-003 (U.S. Army Environmental Hygiene Agency, 1988b). Sludge from the STP was applied to the surface to encourage vegetation. The landfill surface shows evidence of subsidence and leachate seeps. The western part of the landfill is nearly flat. The eastern and southern parts of the landfill are in a shallow drainage that transports water to the southeast (fig. 17). Runoff from FLW-003 eventually enters a small drainage along the southern landfill boundary and flows into an unmaintained impoundment about $0.5 \mathrm{mi}$ to the east adjacent to road FLW 30 . This drainage is a tributary of an unnamed stream referred to as the asphalt plant tributary by Imes and others (1996). The asphalt plant tributary discharges into the Big Piney River about $3 \mathrm{mi}$ to the east. The Roubidoux Formation is the uppermost bedrock unit at the site (fig. 3).

During 1987, the USAEHA installed three shallow (14.5, 43.1, and $42 \mathrm{ft}$ deep) overburden monitoring wells (MW 002, MW 004, and MW 005) at FLW-003 as part of a combined geohydrologic assessment of FLW-003, FLW-004, and FLW-005 (fig. 18) (U.S.

Army Environmental Hygiene Agency, 1988b). These wells were dry and two additional shallow bedrock monitoring wells (101.5 and $58 \mathrm{ft}$ deep; MW 001 and MW 003) were installed during 1990 (U.S. Army Environmental Hygiene Agency, 1990). Only MW 003 contained water, and a sample collected during 1990 was analyzed for specific conductance, $\mathrm{pH}$, selected anions $\left(\mathrm{Cl}, \mathrm{SO}_{4}, \mathrm{~F}\right.$, and $\left.\mathrm{NO}_{2 \mathrm{t}}+\mathrm{NO}_{3 \mathrm{t}}\right)$, trace elements, priority pollutant VOCs and SVs, pesticides, herbicides, and PCBs. The $\mathrm{pH}$ of this sample was 7.8, and only concentrations of $\mathrm{Cl}(6.8 \mathrm{mg} / \mathrm{L}), \mathrm{SO}_{4}(63 \mathrm{mg} / \mathrm{L}), \mathrm{NO}_{2 \mathrm{t}}+\mathrm{NO}_{3 \mathrm{t}}$ $(0.16 \mathrm{mg} / \mathrm{L})$, and $\mathrm{Ba}(210 \mu \mathrm{g} / \mathrm{L})$ were present above their respective detection levels (U.S. Army Environmental Hygiene Agency, 1990).

A review of aerial photographs of FLW-003 and the vicinity taken during 1955, 1964, 1967, 1971, 1976, 1986 , and 1994 confirmed the general dates of operation published by the USAEHA (U.S. Army Environmental Hygiene Agency, 1988a). The landfill was not present on the 1955 or 1964 photographs (fig. 19) or the 1967 photograph (not shown), and the entire FLW-003 area was heavily wooded. The 1971 aerial photograph (not shown) shows two general areas of landfill activity at FLW-003 separated by a north-trending band of trees about 100 to $150 \mathrm{ft}$ wide that extended across the site in the approximate vicinity of soil sample so 015 (fig. 17). The band of trees was removed between 1971 and 1976 , and the western part of the landfill appeared to be completely filled and covered with a light-colored smooth surface that contained a dirt road (fig. 19). No active disturbances or burial trenches were apparent on the 1986 aerial photograph.

The reconnaissance and field sampling at FLW003 was conducted during 1995 and included the collection of 28 soil samples (combined into 5 composite samples) and 2 streambed sediment samples, the sampling of 3 of 11 potential leachate seeps identified, and the collection of samples from monitoring wells MW 003 and MW 005 (the remaining monitoring wells were dry). The samples were analyzed for a variety of inorganic and organic constituents (table 2). Tributaries in the vicinity of FLW-002 were dry, and no surfacewater samples were collected.

Soil and streambed sediment samples from FLW-003 generally contained background concentrations of inorganic constituents (tables 6,7). The only constituents that had concentrations larger than background were phosphorus $(P)(0.12$ percent by weight in soil A), As (18 mg/kg, soil B; $17 \mathrm{mg} / \mathrm{kg}$, sediment sd 002), and $\mathrm{Ba}(530 \mathrm{mg} / \mathrm{kg}$, soil E). The As and $\mathrm{Ba}$ concentrations detected were only slightly larger than background; however, the $\mathrm{P}$ concentration in soil $\mathrm{A}$ was nearly twice the background concentration $(0.07$ percent by weight) and the largest detected in any SWMU soil sample collected (table 6). Streambed sediment samples sd 001 and sd 002 contained small con- 


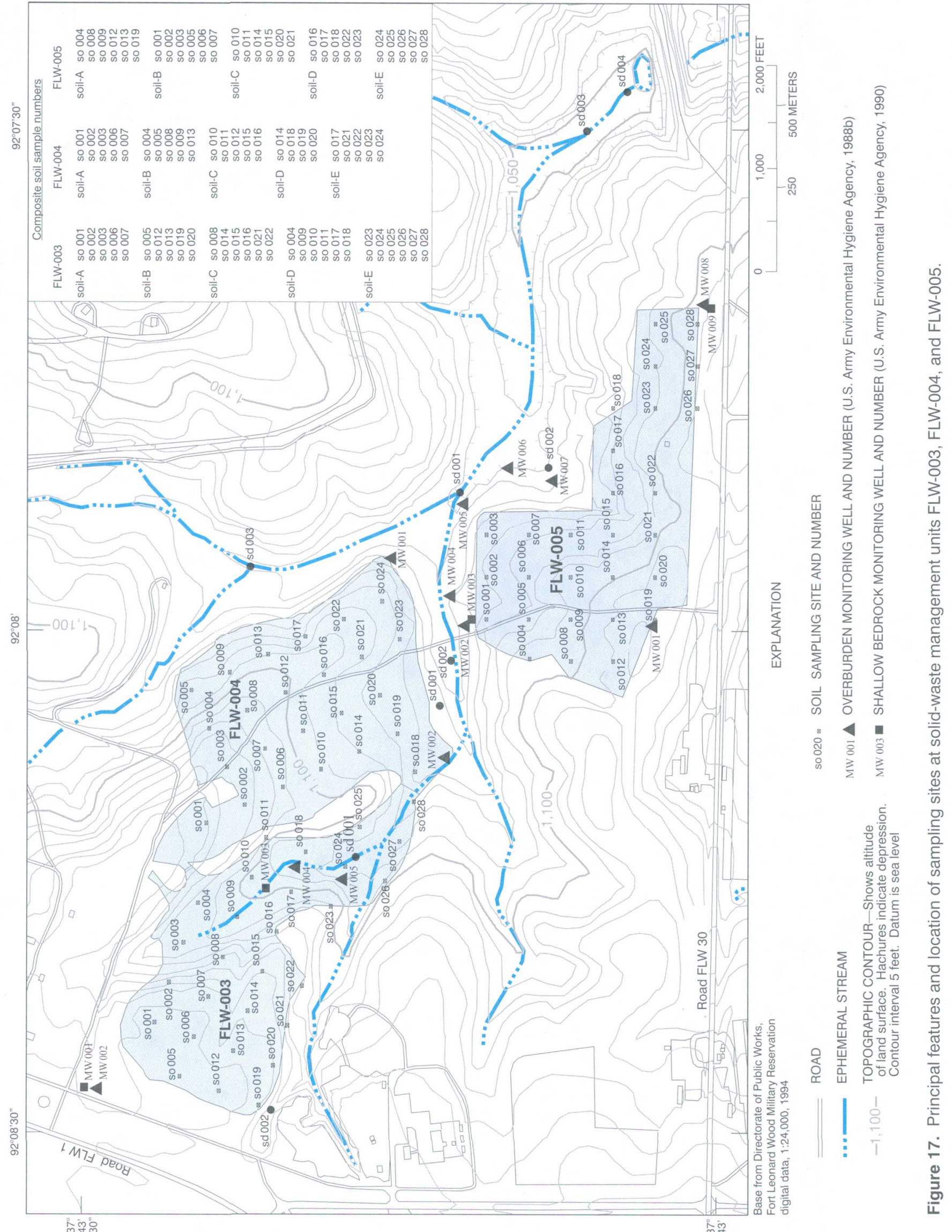




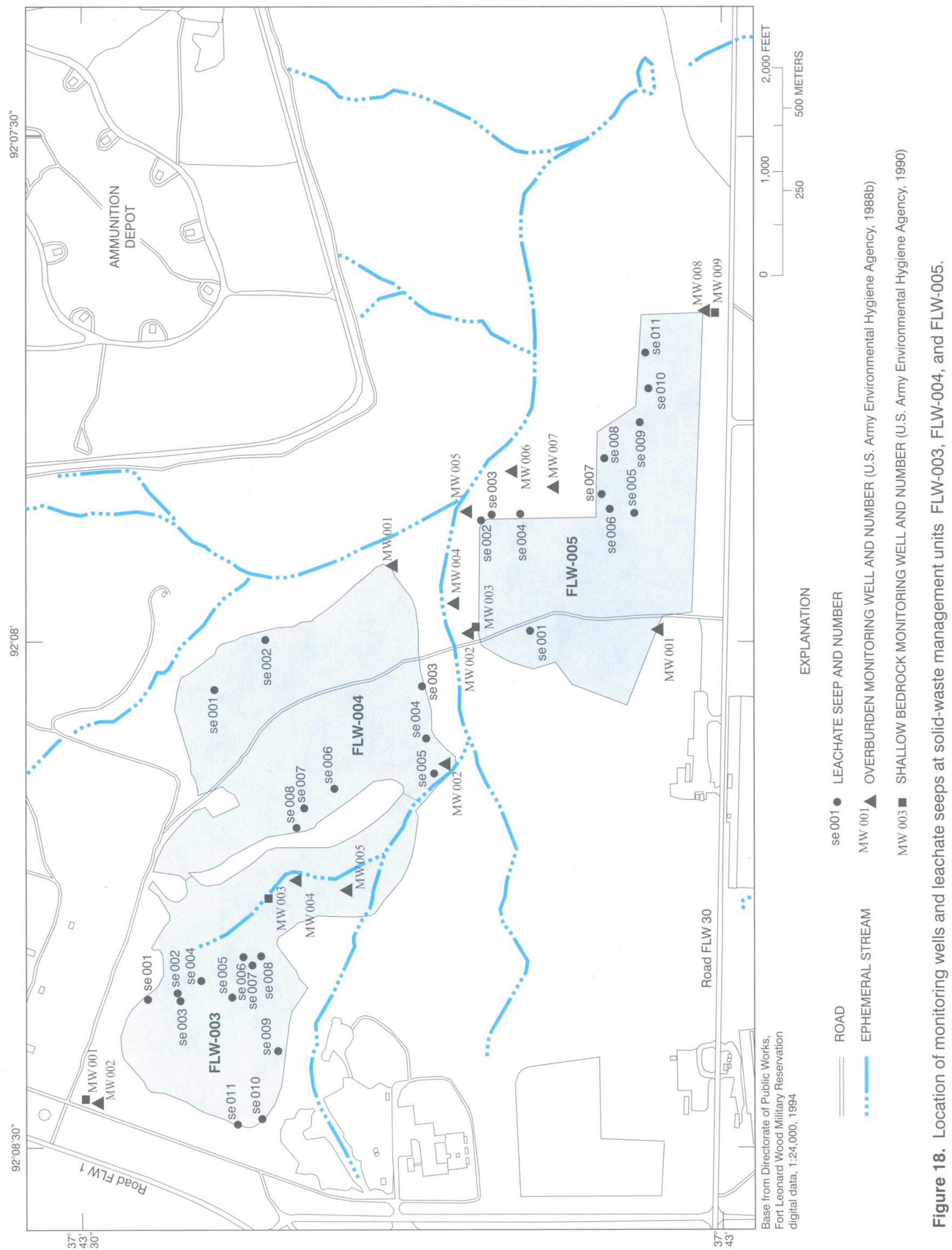




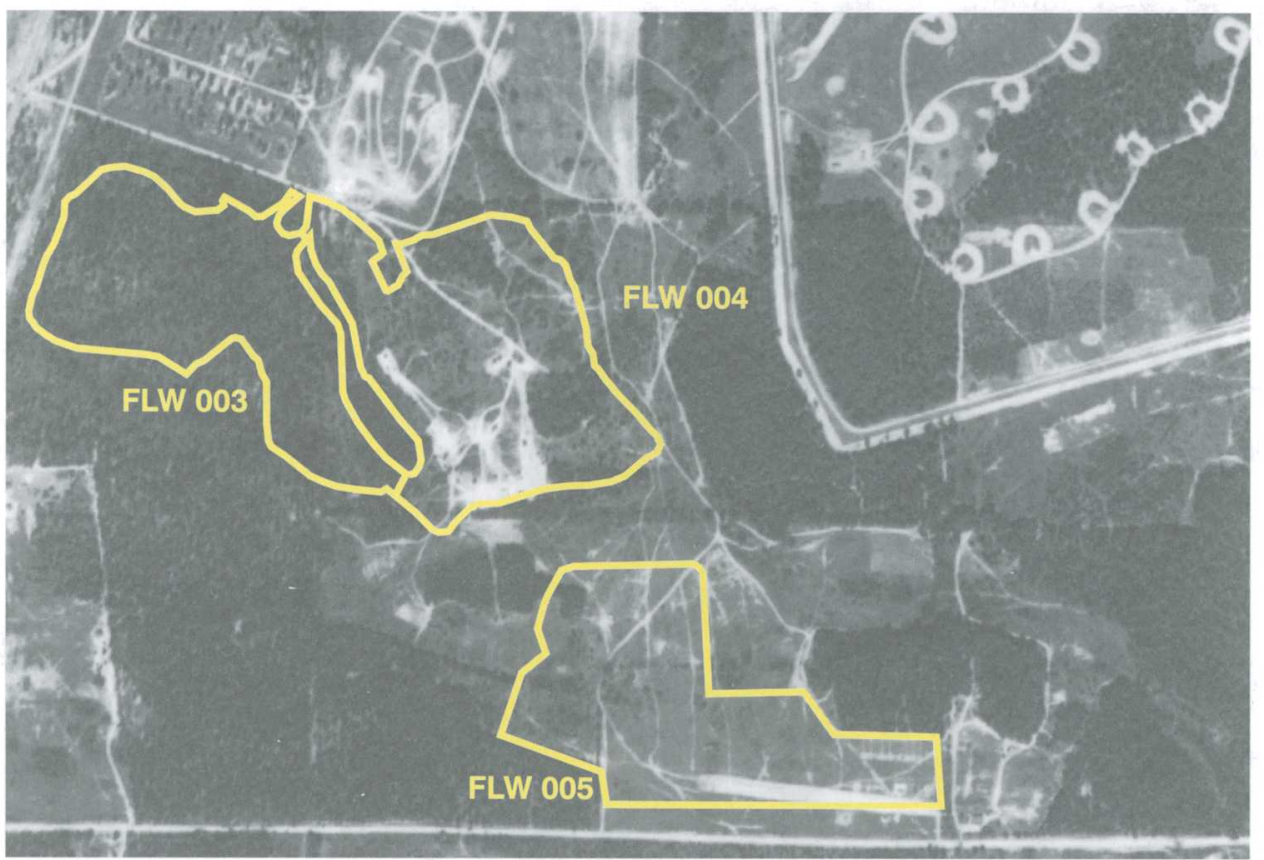

1964

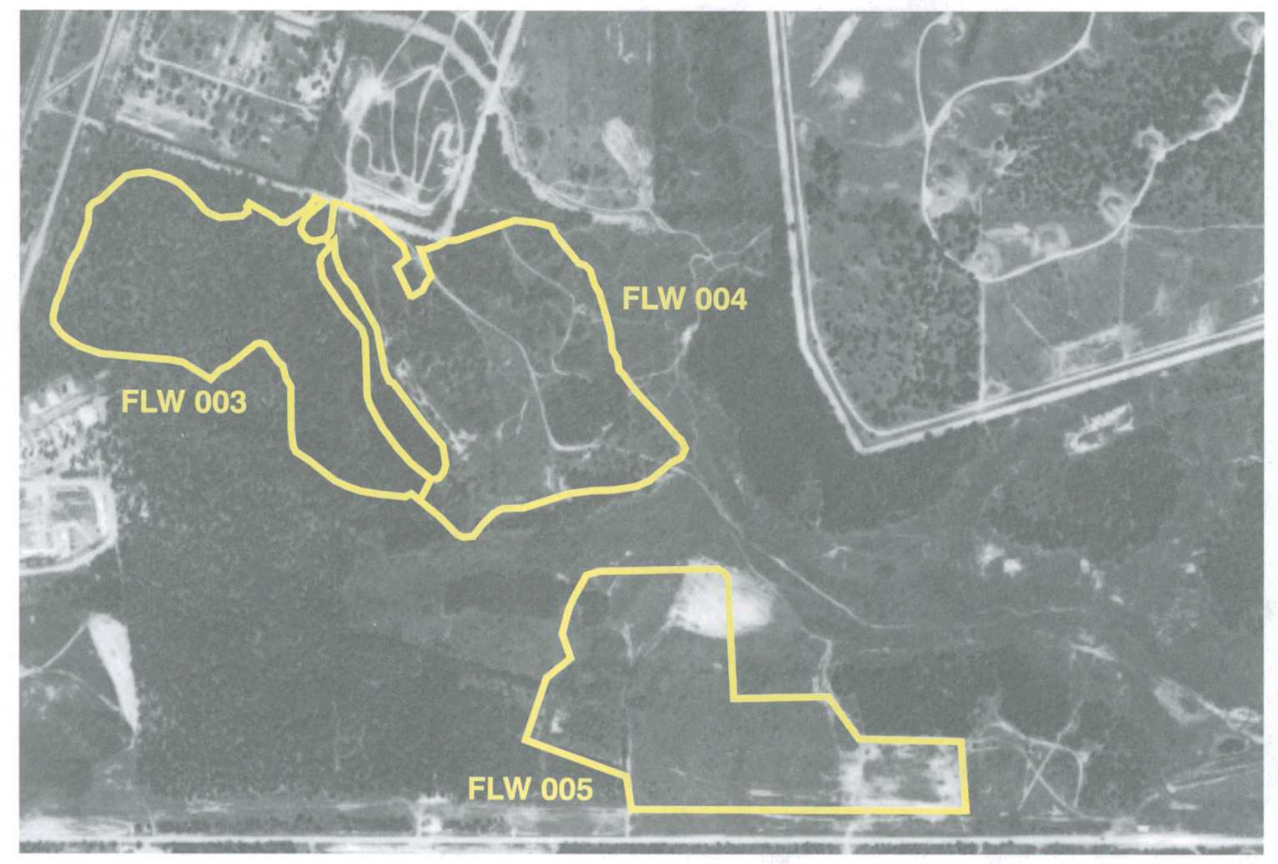

Figure 19. Aerial photographs of solid-waste management units FLW-003, FLW-004, and FLW-005 taken during 1955, 1964, 1976, and 1986. (East-west field of view is approximately 9,800 feet; photographs from Natural Resources Conservation Service.) 


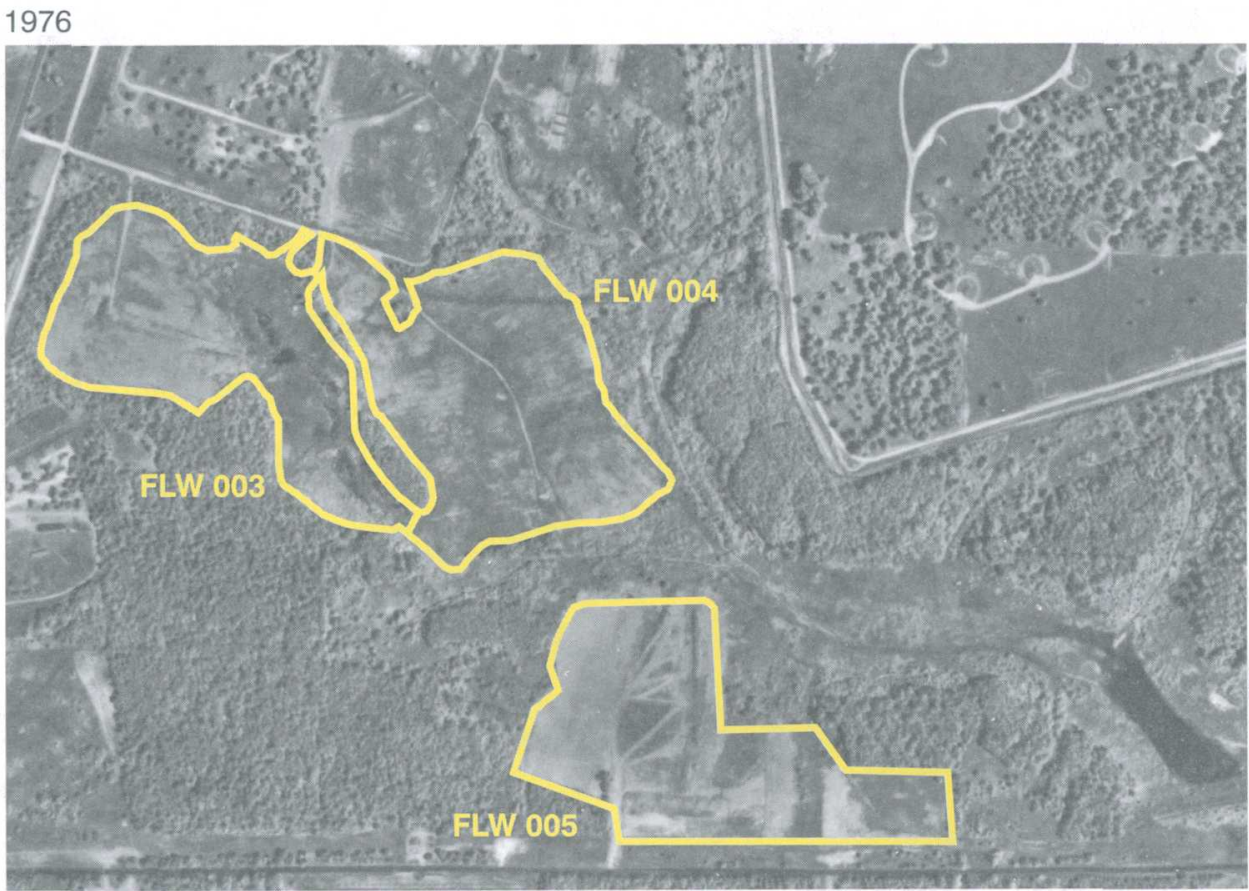

1986

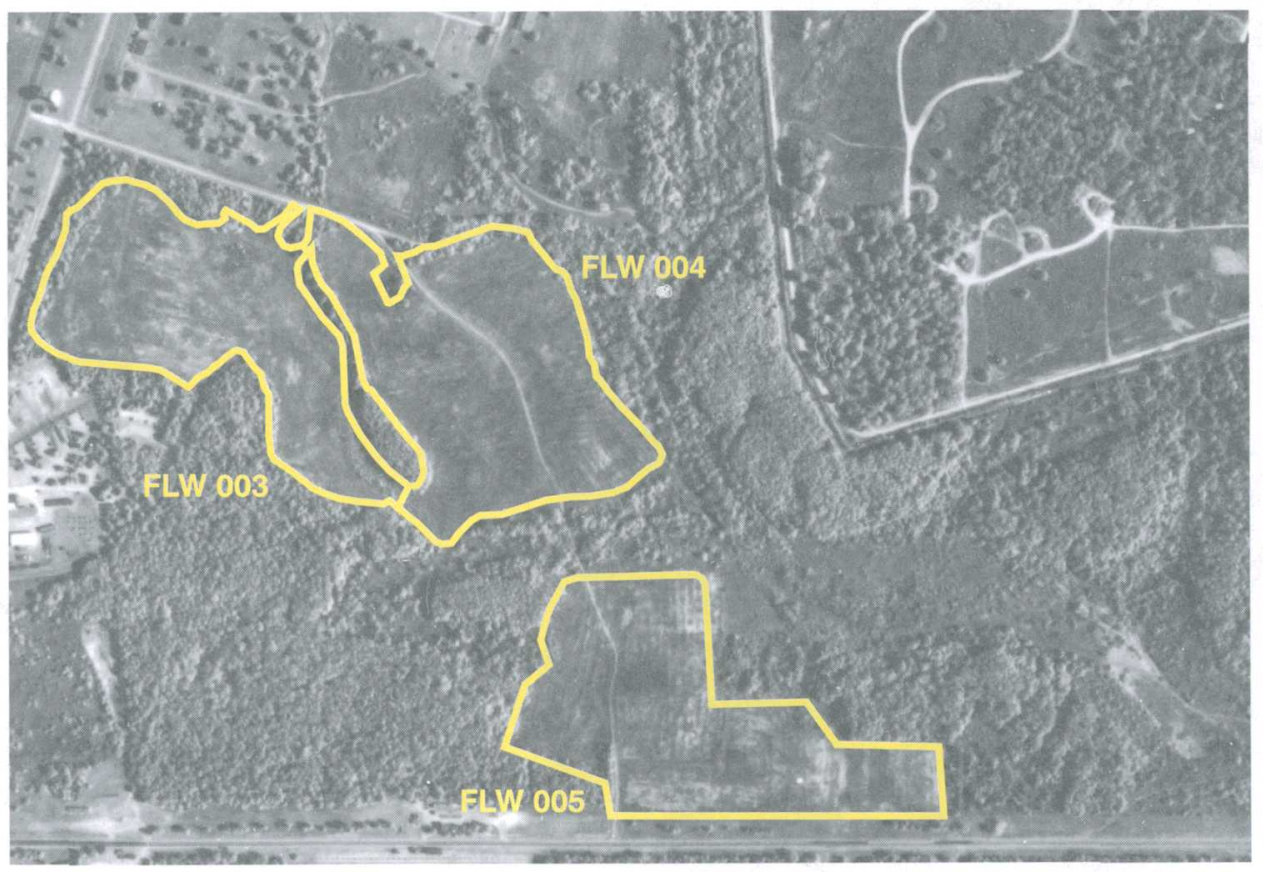

Figure 19. Aerial photographs of solid-waste management units FLW-003, FLW-004, and FLW-005 taken during 1955, 1964, 1976, and 1986-Continued. (East-west field of view is approximately 9,800 feet; photographs from U.S. Forest Service.) 
centrations of DDT [ 1.1 and $0.62 \mu \mathrm{g} / \mathrm{kg}$ (micrograms per kilogram)], DDD ( 0.4 and $4.3 \mu \mathrm{g} / \mathrm{kg})$, DDE (0.83 and $2.0 \mu \mathrm{g} / \mathrm{kg}$ ), and gross PCBs (5.0 and $4.3 \mu \mathrm{g} / \mathrm{kg}$ ) (table 8).

Analyses of water samples collected from three seeps at FLW-003 (se 004, se 005, and se 008) indicate that all seeps have been substantially affected by landfill leachate. The samples had specific conductance values $(1,040$ to $1,910 \mu \mathrm{S} / \mathrm{cm})$ and concentrations of indicator constituents such as $\mathrm{Na}(19$ to $140 \mathrm{mg} / \mathrm{L}$ ), $\mathrm{HCO}_{3}$ (791 and $\left.918 \mathrm{mg} / \mathrm{L}\right), \mathrm{Cl}(16$ to $190 \mathrm{mg} / \mathrm{L}), \mathrm{NH}_{3 \mathrm{t}}$ $(17$ to $30 \mathrm{mg} / \mathrm{L}), \mathrm{Ba}(210$ to $360 \mu \mathrm{g} / \mathrm{L}), \mathrm{B}(210$ to 520 $\mu \mathrm{g} / \mathrm{L}$ ), $\mathrm{Fe}$ (less than 49,000 to $150,000 \mu \mathrm{g} / \mathrm{L}$ ), and $\mathrm{Sr}$ $(170$ to $290 \mu \mathrm{g} / \mathrm{L})$ substantially larger than background. Values of $\mathrm{pH}$ (6.1 to 6.4) also were slightly acidic (table 10). Concentrations of $\mathrm{Pb}_{\mathrm{t}}(20$ and $40 \mu \mathrm{g} / \mathrm{L})$ in samples from seeps se 004 and se 005 and concentrations of $\mathrm{Fe}_{\mathrm{t}}$ $(110,000$ to $170,000 \mu \mathrm{g} / \mathrm{L})$ and $\mathrm{Mn}_{\mathrm{t}}(340$ to $860 \mu \mathrm{g} / \mathrm{L})$ in all three seep samples were larger than the Missouri Ground Water Standard (Missouri Department of Natural Resources, 1996b). Samples from seeps se 004 and se 008 could not be plotted on a trilinear diagram because the sum of milliequivalents of electrical charge of anions, especially $\mathrm{HCO}_{3}$, exceeded the sum of milliequivalents of electrical charges of major cations by more than 20 percent. Concentrations of $\mathrm{HCO}_{3}$ were not available for seep se 005 .

Most of the seeps at FLW-003 had an oily sheen on the surface and, not surprisingly, large concentrations of total VOCs were detected in the samples from seeps se $004(1,062 \mu \mathrm{g} / \mathrm{L})$, se $005(581 \mu \mathrm{g} / \mathrm{L})$, and se $008(520 \mu \mathrm{g} / \mathrm{L})$. The most abundant VOCs detected were hydrocarbons, such as total xylenes (130 to 250 $\mu \mathrm{g} / \mathrm{L}$ ), ethylether (39 to $530 \mu \mathrm{g} / \mathrm{L}$ ), 1,2,4-trimethylbenzene $(24$ to $52 \mu \mathrm{g} / \mathrm{L})$, and napthalene (29 to $64 \mu \mathrm{g} / \mathrm{L}$ ) (table 11). Although none of the samples contained detectable concentrations of the chlorinated solvents PCE or TCE, large concentrations of VC (14 to 131 $\mu \mathrm{g} / \mathrm{L}$ ) were detected, indicating reductive dechlorination of chlorinated solvents has probably occurred within the landfill. The only SV detected in the seep samples was diethylphthalate (6 to $25 \mu \mathrm{g} / \mathrm{L}$ ). The sample from seep se 004 contained a trace quantity of the herbicide alachlor $(0.26 \mu \mathrm{g} / \mathrm{L})$, and the sample from seep se 005 contained a trace quantity of the insecticide carbyl $(0.83 \mu \mathrm{g} / \mathrm{L})$. No seep samples were submitted from FLW-003 for the determination of gross PCBs.

Samples from overburden monitoring wells MW 003 and MW 005 generally had background specific conductance values and concentrations of major con- stituents and do not seem to be affected by landfill leachate. These wells recovered slowly after purging and contained insufficient water for a complete suite of laboratory analyses. Larger than background concentrations of many total trace constituents were detected in the sample from MW 003 (table 10); however, these probably are related to this sample being extremely turbid and containing visible Fe oxide or clay particles. Except for a trace concentration of PCE $(0.2 \mu \mathrm{g} / \mathrm{L})$ detected in the sample from monitoring well MW 003 , no VOCs, SVs, or pesticides were detected in samples from these monitoring wells. Samples from these wells contained small concentrations of chloromethane $(0.2$ and $0.3 \mu \mathrm{g} / \mathrm{L}$ ) that may be related to contaminated $\mathrm{HCl}$ used to preserve these samples.

The estimated altitude of regional ground water in the vicinity of landfill FLW-003 is about $890 \mathrm{ft}$ or more than $200 \mathrm{ft}$ below the land surface, indicating that monitoring wells MW 003 and MW 005 sample perched water within the Roubidoux Formation. A geologic structure map prepared by Harrison and others (1996) indicates that the base of the Roubidoux Formation in the vicinity of FLW-003 is at an altitude of about $980 \mathrm{ft}$, placing the regional water table beneath FLW003 within the Gasconade Dolomite. Based on the regional water-table map, the anticipated direction of ground-water flow at FLW-003 is to the northeast (fig. 2). Dye-trace test T103-14 conducted from MW 003 at FLW-005 confirmed that at least parts of FLW-003, FLW-004, and FLW-005 lie within the recharge basin for Sandstone Spring about $3 \mathrm{mi}$ to the northeast (fig. 5). The positive results for the dye-trace test to Sandstone Spring indicate that contaminants from FLW003, FLW-004, and FLW-005 may migrate quickly to the spring. Water-quality samples collected from Sandstone Spring during 1995 contained larger than background concentrations of $\mathrm{Na}, \mathrm{Cl}$, and $\mathrm{NO}_{2 \mathrm{t}}+\mathrm{NO}_{3 \mathrm{t}}$ and detectable concentrations of the pesticides prometon and simazine (Imes and other, 1996). Several developed areas at the FLWMR, including a subdivision also lie within the Sandstone Spring Basin and without additional dye traces and water-quality samples monitoring wells open to the regional water table beneath FLW-003, FLW-004, and FLW-005, the source of these constituents cannot be unequivocally attributed to these landfills. 


\section{Solid-Waste Management Unit FLW-004}

Solid-waste management unit FLW-004 is a 35.5-acre abandoned landfill immediately east of FLW003 and about $1,000 \mathrm{ft}$ west of the FLWMR ammunition depot (fig. 18). The trench-type landfill reportedly was operated between 1965 and 1978 and used for the disposal of household refuse and unspecified sludges (U.S. Army Environmental Hygiene Agency, 1988a). Sludges from the STP have been applied to the landfill surface to encourage vegetation growth. Ash from the FLWMR heat recovery incinerator also has been applied to the surface of the site (PRC Environmental Management Inc., 1992). The surface in the northwestern part of FLW-004 is poorly vegetated, and the thin cover has been eroded in places exposing some refuse. The eastern and especially southeastern parts of the site tend to have a dense cover of grass. Numerous subsidence features are present, especially in the western part of the site. An unimproved road crosses the middle of the site. The site is bounded on the west, south, and east by surface-water drainages, all of which merge and flow into an unmaintained impoundment about $0.3 \mathrm{mi}$ east of the site (fig. 17). Steep slopes ranging from about 4 to $8 \mathrm{ft}$ high, delineating the boundary of the fill, exist along the drainages to the east and south.

No water-quality data exist for FLW-004. The two shallow (less than $50 \mathrm{ft}$ deep) overburden monitoring wells (MW 001 and MW 002) that were installed at FLW-004 by the USAEHA as part of a geohydrologic assessment of landfills FLW-003, FLW-004, and FLW005 (U.S. Army Environmental Hygiene Agency, 1988b) are dry. Although a follow-up geohydrologic assessment of FLW-003, FLW-004, and FLW-005 was conducted during 1990 (U.S. Army Environmental Hygiene Agency, 1990), no additional monitoring wells were installed at FLW-004. Subsidence features, some containing pooled water, and leachate seeps were noted during a 1991 USEPA site visit; however, no water samples were collected (PRC Environmental Management Inc., 1992).

The preliminary USGS reconnaissance of FLW004 included a review of historical aerial photographs of the site and vicinity taken during 1955, 1964, 1967, $1971,1976,1986$, and 1994. No evidence of landfill activities could be identified on the 1955 and 1964 aerial photographs, although the southwestern part of the site contained numerous roads, trails, and clearings indicative of some type of training activity (fig. 19). The southwestern part of the site was disturbed in the 1967 aerial photograph (not shown) and contained a square clearing about $300 \mathrm{ft}$ wide. The surface of the clearing contained linear features that could be refuse disposal trenches or vehicle ruts; however, the resolution of the photograph was not sufficient to make a positive identification of these features. Substantial landfill activity took place between 1967 and 1971, and most of the site appeared to be covered by the landfill in the 1971 aerial photograph (not shown). The surface of the site in the 1971 photograph generally appeared smooth; however, a nearly circular pond was present in the northwestern part of the site, and the southeastern part of the site appeared to be uneven and more intensely disturbed-possibly an active fill area. The site did not appear to be active in the 1976 aerial photograph, and the surface appeared smooth with eastwest trending linear features that could be burial trenches (fig. 19). The surface of the site was poorly vegetated in the 1986 aerial photograph, and rows of burial trenches were readily distinguishable. The surface of the landfill appeared recently disturbed in the 1994 aerial photograph (not shown) with trench rows readily distinguishable and little visible vegetation.

The recent disturbance probably was related to regrading of the landfill surface in response to recommendations made by the USAEHA for erosion control (U.S. Army Environmental Hygiene Agency, 1990).

The initial reconnaissance and sampling at FLW004 was conducted during 1995 and included the collection of 25 soil samples (combined in 5 composite samples) and 3 streambed sediment samples (fig. 17) and the sampling of 3 of the 8 seeps identified at the site (fig. 18). Tributaries bordering the site and monitoring wells MW 001 and MW 002 were dry. The soil, streambed sediment, and seep samples were analyzed for the suite of constituents listed in table 2 .

Soil and streambed sediment samples from FLW-004 generally contained background concentrations of inorganic constituents (tables 6, 7). Concentrations of TOC, however, in streambed sediment samples from FLW-004 (fig. 15) were the largest detected during this assessment. Streambed sediment samples from FLW-004 contained small concentrations (less than 2 $\mu \mathrm{g} / \mathrm{kg}$, table 8) of organochlorine pesticides or their degradation products (DDT, DDD, DDE, dieldrin, and heptachlor epoxide) and slightly larger concentrations of gross PCBs (less than 1 to $15 \mu \mathrm{g} / \mathrm{kg}$ ).

Seeps sampled at FLW-004 have been affected by landfill leachate. Water-quality samples collected from seeps se 002 and se 007 contained concentrations of indicator constituents such as $\mathrm{Na}(5.6 \mathrm{and} 15 \mathrm{mg} / \mathrm{L})$, 
$\mathrm{NH}_{3 \mathrm{t}}(11$ and $14 \mathrm{mg} / \mathrm{L}), \mathrm{Ba}(195$ and $370 \mu \mathrm{g} / \mathrm{L}), \mathrm{B}(120$ and $190 \mu \mathrm{g} / \mathrm{L}), \mathrm{Fe}(29,700$ and $48,300 \mu \mathrm{g} / \mathrm{L})$, and $\mathrm{Sr}$ $(120$ and $180 \mu \mathrm{g} / \mathrm{L})$, and other constituents larger than background (table 10). Concentrations of $\mathrm{Cl}(8.2$ $\mathrm{mg} / \mathrm{L}), \mathrm{NH}_{3 \mathrm{t}}(0.6 \mathrm{mg} / \mathrm{L}), \mathrm{B}(30 \mu \mathrm{g} / \mathrm{L}), \mathrm{Fe}(84 \mu \mathrm{g} / \mathrm{L})$, and $\operatorname{Sr}(145 \mu \mathrm{g} / \mathrm{L})$ in the sample from se 001 also were larger than background. In general, the specific conductance values ( 380 to $651 \mu \mathrm{S} / \mathrm{cm}$ ) and concentrations of most inorganic constituents in samples from these seeps were smaller than those in seep samples from FLW-002 and FLW-003 (table 10). Seeps at FLW-004 were sampled during a relatively wet period, and constituent concentrations may be diluted by rainfall and runoff. Samples from seeps se 002 and se 007 contained VOCs ( 51.6 and $68.9 \mu \mathrm{g} / \mathrm{L}$ total VOCs) with the predominant compounds detected being acetone (12 and $34 \mu \mathrm{g} / \mathrm{L}$ ) and substituted benzenes (table 11). Small concentrations of $\mathrm{VC}(2.0$ and $3.1 \mu \mathrm{g} / \mathrm{L})$ and cis-DCE $(0.5$ and less than $0.2 \mu \mathrm{g} / \mathrm{L}$ ) also were detected in samples from seeps se 002 and se 007 . Small concentrations of acetone $(7.4 \mu \mathrm{g} / \mathrm{L})$ and other VOCs were detected in the sample from seep se 001 . The sample from seep se 002 also contained small concentrations of the SV pseudocummene $(3.5 \mu \mathrm{g} / \mathrm{L})$ and estimated trace concentrations of the pesticides carbyl $(0.002$ $\mu \mathrm{g} / \mathrm{L})$ and lindane $(0.033 \mu \mathrm{g} / \mathrm{L})$.

The geohydrology of FLW-004 is similar to that of FLW-003. The uppermost bedrock unit beneath the site is the Roubidoux Formation, which probably is unsaturated. This site lies at the northern edge of the recharge basin of Sandstone Spring, and contaminants introduced to the water table beneath the site may emerge at this spring. Because of the heterogeneous lithology and variable attitude of bedding planes in the underlying Roubidoux Formation and thick unsaturated zone beneath the site, contaminants migrating downward from FLW-004 to the regional water table may migrate along complex routes and migrate laterally in various directions before reaching the regional water table.

\section{Solid-Waste Management Unit FLW-005}

Solid-waste management unit FLW-005 is a 29.5-acre trench-type sanitary landfill about $1 \mathrm{mi}$ east of road FLW 1 and immediately south of landfill FLW004. The landfill began operations sometime between 1965 and 1968 and closed during 1978 (U.S. Army Environmental Hygiene Agency, 1988a; PRC Environmental Management Inc., 1992). The landfill was used for the disposal of household wastes and unspecified sludges (U.S. Army Environmental Hygiene Agency, 1988a). The surface of the site generally slopes to the north, and runoff from the site flows into a shallow drainage that flows about $0.25 \mathrm{mi}$ to the east into an unmaintained impoundment (fig. 18).

Seven overburden monitoring wells (MW 001, MW 002, MW 004, MW 005, MW 006, MW 007, and MW 008) were installed at FLW-005 in 1987 (U.S. Army Environmental Hygiene Agency, 1988b). The wells were installed at depths ranging from 8 (MW 004) to $47.7 \mathrm{ft}$ (MW 006) below the land surface (table 3). Immediately after installation, all the wells were dry; however, during a site visit 4 months later, MW 006 contained water, and a sample was collected for the determination of specific conductance, $\mathrm{pH}$, selected anions $\left(\mathrm{Cl}, \mathrm{SO}_{4}, \mathrm{~F}\right.$, and $\left.\mathrm{NO}_{2 \mathrm{t}}+\mathrm{NO}_{3 \mathrm{t}}\right)$, trace elements, priority pollutant VOC and SV, pesticides, herbicides, and PCBs (U.S. Army Environmental Hygiene Agency, 1988b). The specific conductance value (50 $\mu \mathrm{S} / \mathrm{cm})$, concentrations of major ions such as $\mathrm{Ca}(3.6$ $\mathrm{mg} / \mathrm{L}), \mathrm{Mg}(1.3 \mathrm{mg} / \mathrm{L}), \mathrm{Na}(4.3 \mathrm{mg} / \mathrm{L})$, and $\mathrm{Cl}(1.9$ $\mathrm{mg} / \mathrm{L})$, and $\mathrm{Alk}_{\mathrm{t}}(18 \mathrm{mg} / \mathrm{L})$ were unusually small for ground water, indicating that recent infiltration of rainwater was being collected in this well. Two shallow (101 and $100.5 \mathrm{ft}$ deep) bedrock monitoring wells (MW 003 and MW 009) were installed at the site during 1990 (U.S. Army Environmental Hygiene Agency, 1990); however, both of these wells also were dry.

The preliminary USGS reconnaissance of FLW005 included a review of historical aerial photographs of the site and vicinity taken during 1955, 1964, 1967, $1971,1976,1986$, and 1994. No landfill activity was apparent on the 1955 photograph; however, there was considerable land disturbance at the site related to some type of training activity. Although landfill activities at FLW-005 reportedly began between 1965 and 1968 (U.S. Army Environmental Hygiene Agency, 1988a; PRC Environmental Management, Inc., 1992), a rectangular disturbance that appeared to be landfill activity was apparent in the southeast part of the site on the 1964 aerial photograph (fig. 19). A detailed review of the 1964 stereoscopic aerial photographs indicated the rectangular disturbance was a depression containing east-west oriented linear features that may be refuse disposal trenches. During 1976, refuse disposal appeared to be occurring in north-south oriented trenches in the northeast part of the site (fig. 19). By 
1986, the western part of the site had been filled, and the entire site appeared to have been graded and was covered by sparse vegetation (fig. 19).

Field sampling at FLW-005 was conducted during 1995 and included the collection of 28 soil samples (combined in 5 composite samples) and 4 streambed sediment samples (fig. 17). Water-quality samples also were collected from 3 of the 11 seeps identified at the site. Vicinity tributaries and the nine existing monitoring wells at the site were dry during the 1995 sampling visit. The soil, streambed sediment, and seep samples were analyzed for the suite of constituents listed in table 2.

Soil and streambed sediment samples from FLW-005 generally contained background concentrations of inorganic constituents (tables 6, 7). Except for streambed sediment sample sd 002 , the location of the remaining streambed sediment sampling sites also were downstream from FLW-003 and FLW-004 (fig. 17). Streambed sediment samples contained trace concentrations (less than $1 \mu \mathrm{g} / \mathrm{kg}$ ) of organochlorine pesticides or their degradation products (DDT, DDD, DDE, dieldrin, and heptachlor epoxide) and slightly larger concentrations of gross PCBs (1.7 to $3.2 \mu \mathrm{g} / \mathrm{kg}$, table 8). Streambed sediment sample sd 004 also contained a trace concentration of the pesticide malathion (estimated concentration of $0.1 \mu \mathrm{g} / \mathrm{L}$ ). The small concentrations of pesticides and gross PCBs detected in streambed sediment samples from FLW-005 are comparable to concentrations detected in streambed sediment samples from other SWMU at the FLWMR.

Results of laboratory analyses of samples from seeps at FLW-005 indicate substantial effects from landfill leachate. Samples from all three seeps sampled (se 006, se 009, and se 010) had slightly acidic $\mathrm{pH}$ values (6.0 to 6.2), and specific conductance values (595 to $885 \mu \mathrm{S} / \mathrm{cm})$ and concentrations of indicator constituents $\mathrm{Na}(7.6$ to $14 \mathrm{mg} / \mathrm{L}), \mathrm{HCO}_{3}$ (473 to $649 \mathrm{mg} / \mathrm{L}$ ), $\mathrm{Cl}(16$ to $21 \mathrm{mg} / \mathrm{L}), \mathrm{NH}_{3 \mathrm{t}}$ (12 to $\left.17 \mathrm{mg} / \mathrm{L}\right), \mathrm{Ba}(190$ to $500 \mu \mathrm{g} / \mathrm{L}), \mathrm{B}(150$ to $190 \mu \mathrm{g} / \mathrm{L}), \mathrm{Fe}(54,000$ to 130,000 $\mu \mathrm{g} / \mathrm{L}), \mathrm{Mn}(460$ to $3,900 \mu \mathrm{g} / \mathrm{L})$, and $\operatorname{Sr}(200$ to 400 $\mu \mathrm{g} / \mathrm{L}$ ) larger than background (table 10 ). Similar to seep samples from FLW-003, the milliequivalents of electric charge contributed by major anions, especially $\mathrm{HCO}_{3}$, in seep samples from FLW-005 greatly exceeded the milliequivalance of electrical charge contributed by the major cations and probably were caused by the presence of organic acid anions that were titrated during the procedure used to determine total alkalinity and $\mathrm{HCO}_{3}$ concentrations. Seep samples also contained detectable concentrations of VOCs (44 to $213 \mu \mathrm{g} / \mathrm{L}$ total VOCs), the SV diethylphthalate $(11 \mu \mathrm{g} / \mathrm{L})$ and pseudocummene ( 1 to $22 \mu \mathrm{g} / \mathrm{L}$ ), and the pesticide carbyl $(0.32$ to $2.6 \mu \mathrm{g} / \mathrm{L})$. Similar to seep samples from FLW-004, the predominant VOCs detected in seep samples from FLW-005 were substituted benzenes, such as total xylenes $(9.0$ to $83 \mu \mathrm{g} / \mathrm{L})$ and $1,2,4$-trimethylbenzene (1.0 to $22 \mu \mathrm{g} / \mathrm{L}$ ) and acetone (less than 0.4 to $16 \mu \mathrm{g} / \mathrm{L}$, table 11 ). Samples from seeps se 006 and se 009 also contained small concentrations of cis-DCE ( 0.5 and $0.9 \mu \mathrm{g} / \mathrm{L}$ ), and samples from all three seeps contained detectable concentrations $(0.6$ to $7.9 \mu \mathrm{g} / \mathrm{L})$ of VC (table 11) suggesting that chlorinated solvents, such as PCE, were disposed in the landfill.

The geohydrology of FLW-005 is similar to that of FLW-003 and FLW-004. The uppermost bedrock unit beneath the site is the Roubidoux Formation, which is generally unsaturated. The general direction of the regional ground-water flow at the site is to the northeast. A dye-trace test conducted from MW 003 (T103-14) (fig. 5) indicated a subsurface connection between FLW-005 and Sandstone Spring. Contaminants introduced to the water table beneath the site may emerge at this spring. Because of the heterogeneous lithology and variable attitude of bedding planes in the underlying Roubidoux Formation and the thick unsaturated zone beneath the site, contaminants migrating downward from FLW-005 to the regional water table may migrate along complex routes and migrate laterally in various directions before reaching the regional water table.

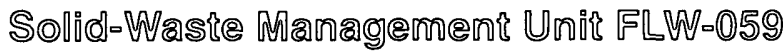

Solid-waste management unit FLW-059 is an approximately 3.5-acre closed sanitary landfill in the northwestern part of the FLWMR (fig. 2). The site is within the Roubidoux Creek alluvium adjacent to road FLW 8 and immediately east of Roubidoux Creek (fig. 20). As many as three closed sanitary landfills may exist in the general vicinity of FLW-059 (Environmental Science and Engineering, 1982). These landfills were originally designated as landfills 15,16 , and 17 and reportedly were used during the late 1950's and early 1960's for the disposal of household wastes. Based on a generalized site map prepared for the USAEHA, FLW-059 seems to be the landfill formerly designated as landfill 16 (Environmental Science and Engineering, 1982). No site specific information exists regarding the location of these closed landfills; how- 


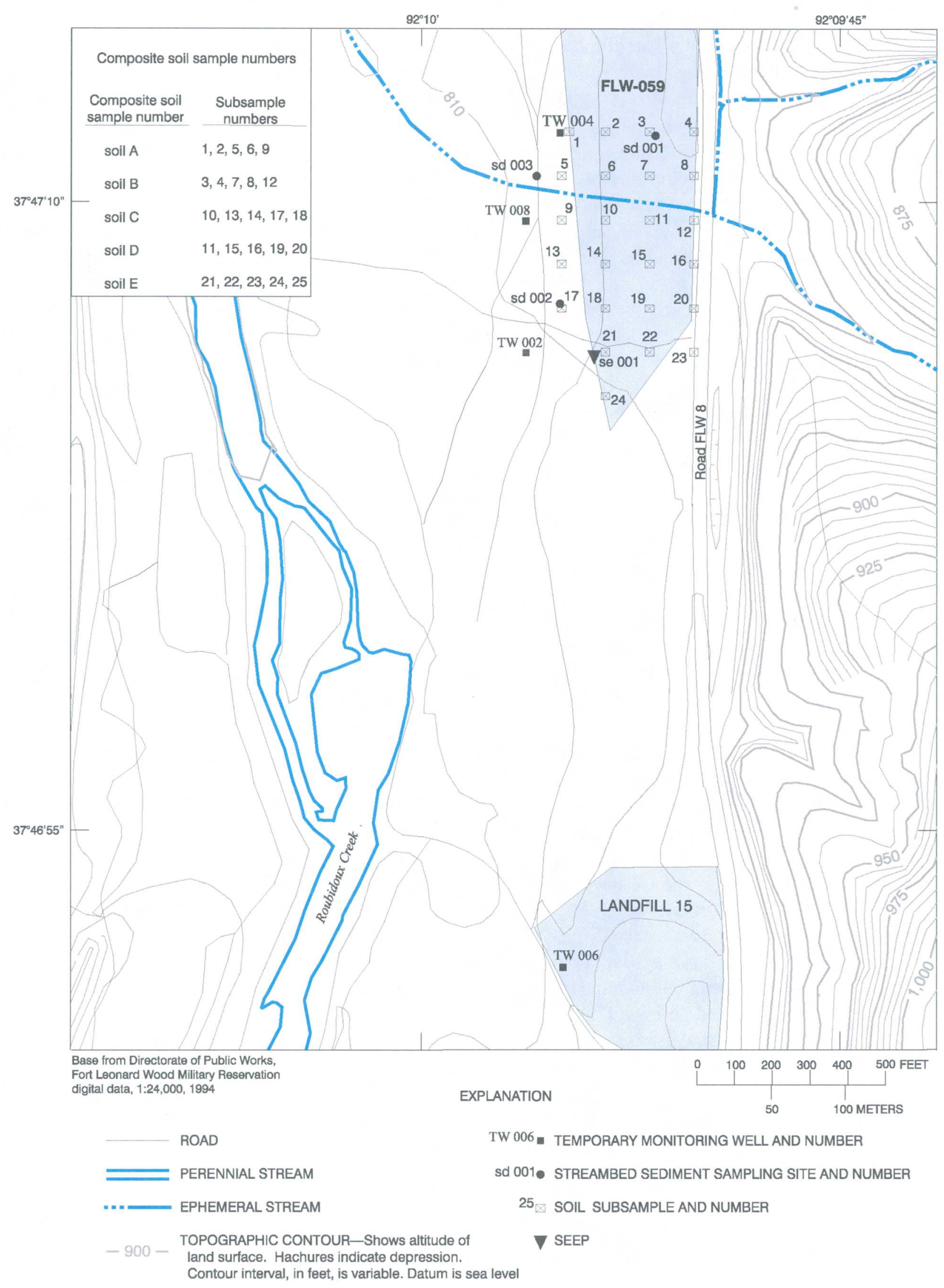

Figure 20. Principal features and sampling sites at solid-waste management unit FLW-059. 
ever, several signs indicating a sanitary landfill boundary were observed in the approximate vicinity of FLW059 during the reconnaissance of the site during 1995.

A review of historical aerial photographs of the FLW-059 site and vicinity taken during 1955, 1964, $1967,1971,1975$, and 1986 confirm the presence of at least three probable landfilled areas. These three areas probably correspond to formally designated landfills 15, 16, and 17 (Environmental Science and Engineering, 1982) and are delineated on the aerial photographs shown in figure 21. During 1955, nearly the entire floodplain east of Roubidoux Creek was disturbed by training activities; however, none of the disturbances appeared to be related to landfill activities. A small arms firing range occupied the southern one-third of the floodplain east of Roubidoux Creek and impact berms were visible on both sides of the creek. The ranges appeared to be recently constructed because most of the land surface was barren of nearly all vegetation. During 1955, the FLW-059 area contained several small roads or trails but no apparent excavations. The area encompassing landfill 17 northwest of FLW059 appeared relatively undisturbed during 1955 . The landfill 15 area was cleared during 1955 and contained a cluster of small, dark objects that may be small firing range support buildings or vehicles.

Although previous studies indicated FLW-059 and nearby landfills 15 and 17 were operated during the later 1950's and early 1960's, no disturbances attributed to landfill activity were apparent on the 1955 aerial photograph (fig. 21). During 1964, the entire area was less disturbed than in the 1955 photograph and generally was covered by low vegetation, especially on the firing ranges. The FLW-059 area, however, appeared to have some sort of active surface disturbance during 1964. The FLW-059 site appeared relatively undisturbed in the 1971 aerial photograph (not shown), but was actively disturbed during 1975 (fig. 21). Excavation and probable refuse disposal appeared to be occurring in the north-central part of the site in the vicinity of the shallow drainage crossing the site. Some excavation also was occurring in the western part of the landfill 17 site during 1975 that may be related to landfill activities. In the 1986 aerial photograph, the surface of FLW-059 appeared smooth and grass covered with a single clump of trees in the northern part of the site, indicating that landfill activities had ceased. The land surface north of FLW-059 contained linear features (dashed area on the 1986 photograph in fig. 21), denoting that some type of earth-moving activity occurred in this area between 1975 and 1986. The surface of landfill 15 in the 1986 aerial photograph was covered by north-south oriented linear features that appear to be refuse disposal trenches, which also indicates that refuse disposal may have occurred in this area between 1975 and 1986.

Field sampling at FLW-059 was conducted during 1995 and included the collection of 25 soil samples (combined in 5 composite samples) and 3 streambed sediment samples (fig. 20). Topography in the vicinity of the site is relatively flat and the streambed sediment samples were collected from shallow drainages or areas where sediment appeared to have been deposited. One small damp area indicating a seep (se 001) was noted during the field reconnaissance; however, insufficient water was available for sampling. The field reconnaissance was done during July, and the dry conditions and low relief of the site probably contributed to the lack of observed surface seeps. Except for Roubidoux Creek, none of the drainages were flowing, although there was some pooled water in the vicinity of sediment sampling site sd 003 (fig. 20).

Soil and streambed sediment samples from FLW-059 generally contained background concentrations of inorganic constituents (tables 6, 7); however, composite soil sample A contained concentrations of $\mathrm{Zn}(280 \mathrm{mg} / \mathrm{kg})$ substantially larger than background (table 6). Streambed sediment samples contained small concentrations (less than $5 \mu \mathrm{g} / \mathrm{kg}$ ) of organochlorine pesticides or their degradation products (chlordane, DDT, DDD; DDE, and dieldrin) and larger concentrations of gross PCBs (2.4 to $42 \mu \mathrm{g} / \mathrm{kg}$ ). Streambed sediment sample sd 002 also contained a trace concentration of the pesticide trithion (estimated concentration of $0.1 \mu \mathrm{g} / \mathrm{L}$ ).

Because of the lack of surface seeps and absence of ground-water quality data, four temporary monitoring wells were installed in the vicinity of FLW-059 and landfill 15 during August 1997 (fig. 22). The wells were installed to depths of 18 to $20 \mathrm{ft}$ using a tractormounted drill rig and 6-in. ID hollow-stem augers. No annular seal was used, and the boreholes were allowed to collapse around the well screen and riser after the augers were removed. The upper 3 to $6 \mathrm{ft}$ of the alluvium in the boreholes consisted of dark brown silt and silty sand. At depths greater than about $6 \mathrm{ft}$, gravel and cobbles were encountered, which caused refusal of the augers in 6 of the 10 holes attempted. The first borehole advanced was located about $20 \mathrm{ft}$ west of seep se 001 (fig. 20). This borehole encountered refuse at a depth of 
1955

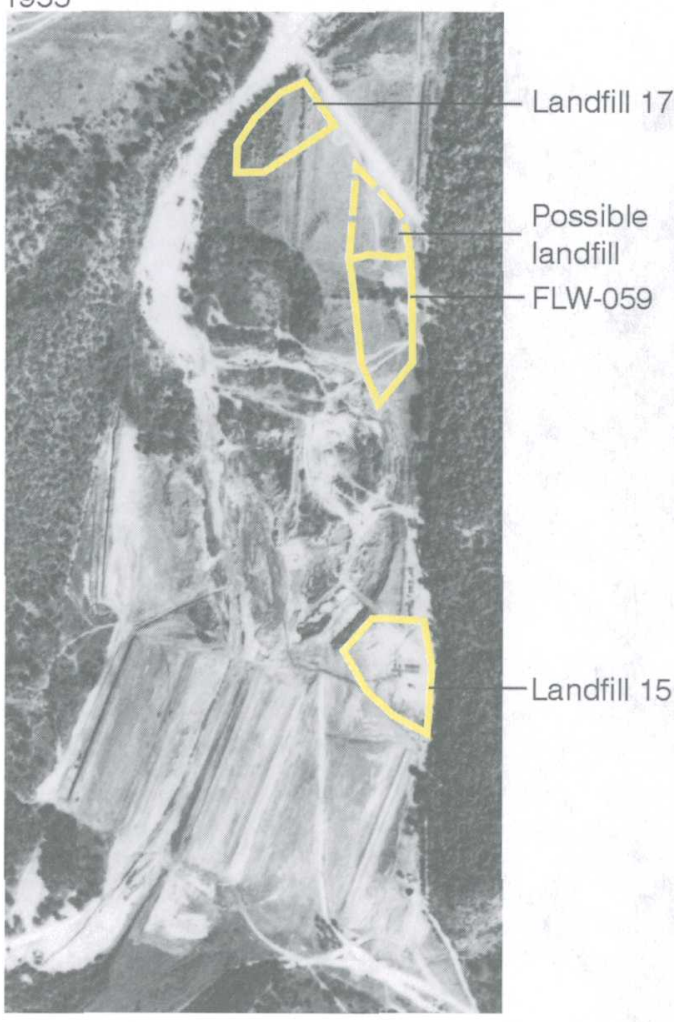

1975

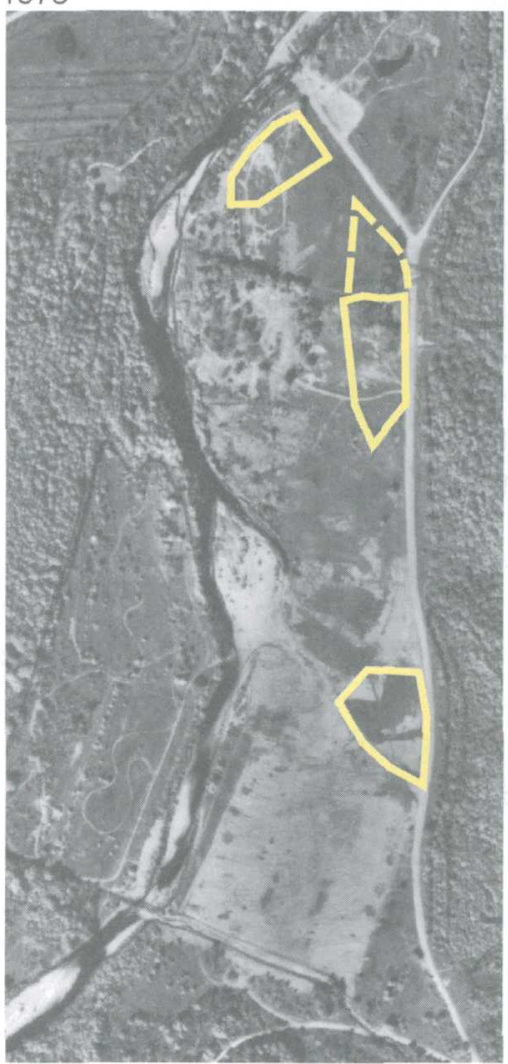

1964

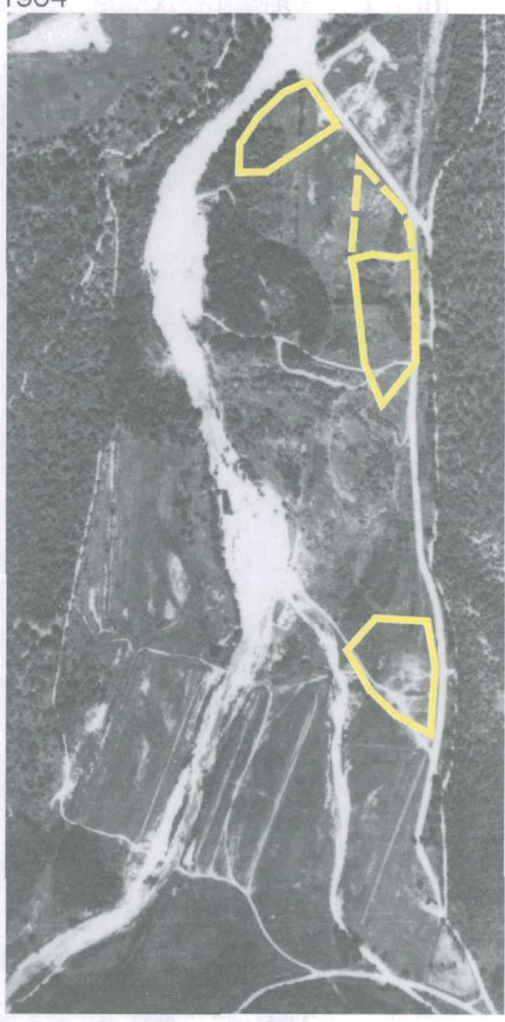

1986

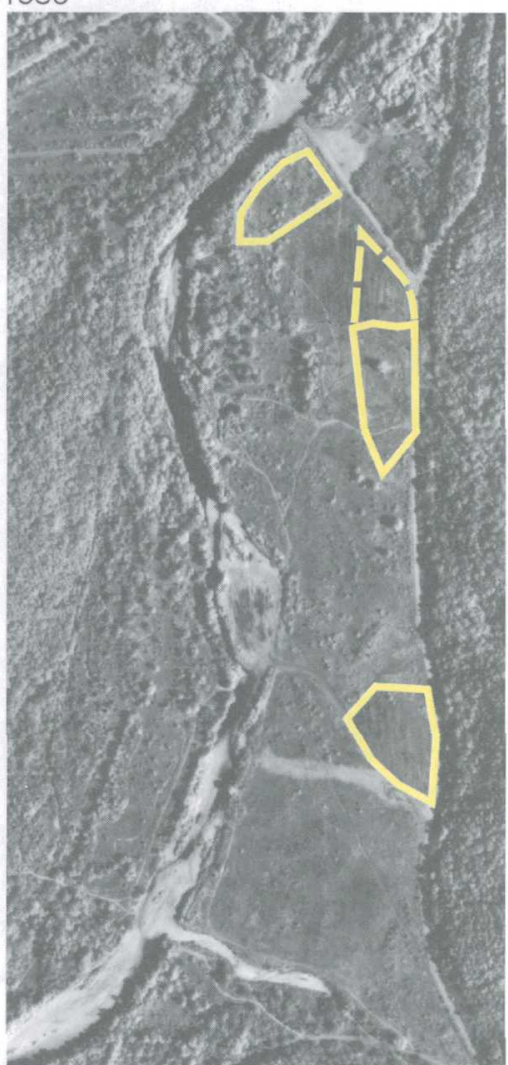

Figure 21. Aerial photographs of solid-waste management unit FLW-059 taken during $1955,1964,1975$, and 1986 . (East-west field of view is approximately 2,800 feet; top photographs from Natural Resources Conservation Service; bottom photographs from U.S. Forest Service.) 


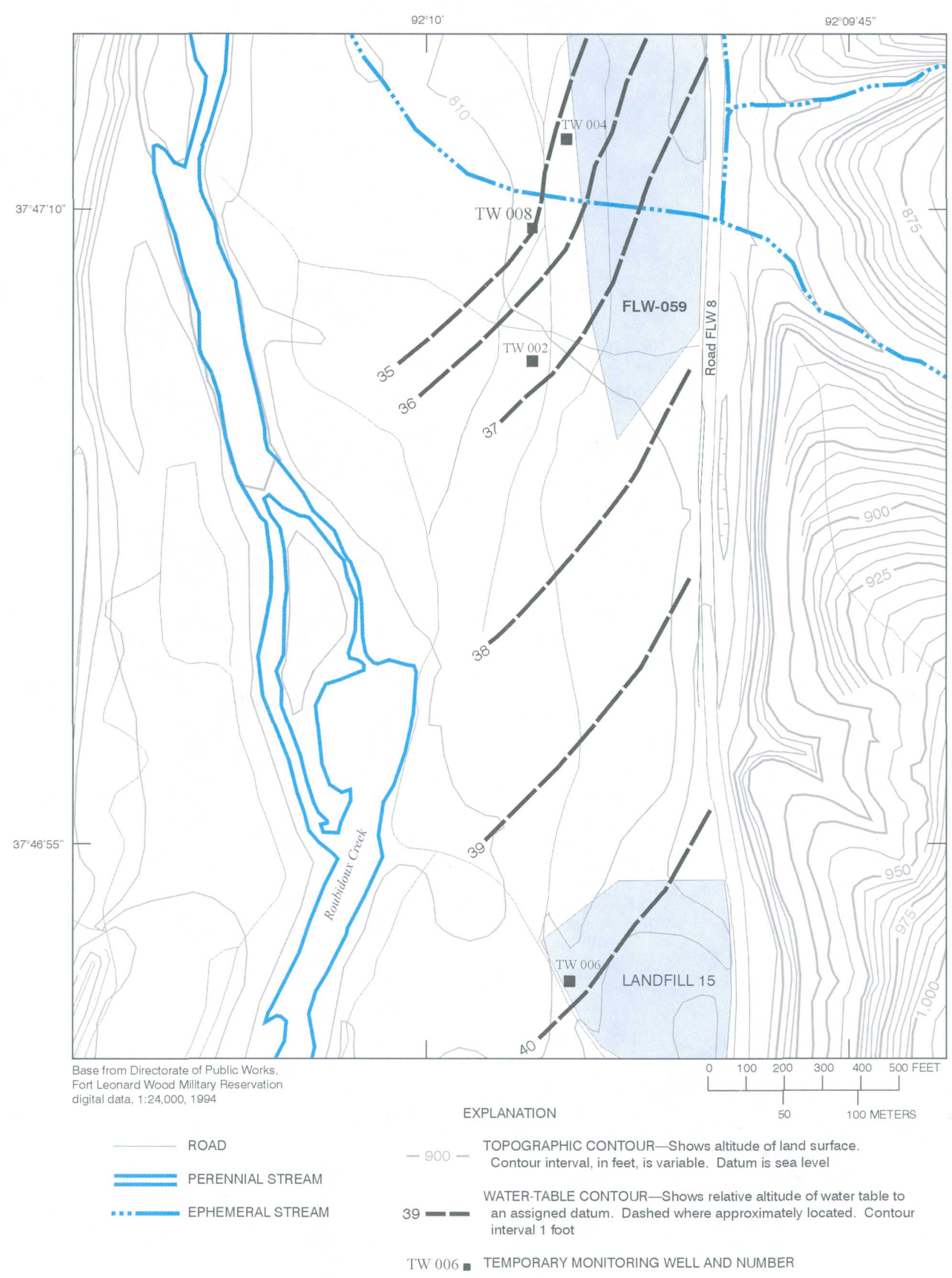

Figure 22. Location of temporary monitoring wells and altitude of shallow ground water at solid-waste management unit FLW-059. 
$2 \mathrm{ft}$, confirming the use of this area as a sanitary landfill, and was abandoned. Depths to water in the four wells successfully installed ranged from about $11.6 \mathrm{ft}$ below land surface in TW 002 and TW 006 to about $16.5 \mathrm{ft}$ below land surface in TW 008 (table 10). The wells were sampled during August and September 1997 and abandoned shortly after sampling.

Analytical results of water samples collected from the temporary monitoring wells indicate that the alluvial water quality in the vicinity of FLW-059 probably has been affected by landfill leachate. The sample from TW 002 had larger than background specific conductance $(680 \mu \mathrm{S} / \mathrm{cm})$ and larger than background concentrations of the indicator constituents $\mathrm{Na}(19 \mathrm{mg} / \mathrm{L})$, $\mathrm{Cl}(43 \mathrm{mg} / \mathrm{L}), \mathrm{NH}_{3 \mathrm{t}}(0.34 \mathrm{mg} / \mathrm{L}), \mathrm{Ba}(300 \mu \mathrm{g} / \mathrm{L}), \mathrm{B}(39$ $\mu \mathrm{g} / \mathrm{L})$, and $\operatorname{Sr}(99 \mu \mathrm{g} / \mathrm{L})$ (table 10$)$. The sample from TW 006 contained larger than background concentrations of $\mathrm{K}(3.2 \mathrm{mg} / \mathrm{L})$ and $\mathrm{NH}_{3 \mathrm{t}}(2.1 \mathrm{mg} / \mathrm{L})$, and samples from TW 004 and TW 006 contained larger than background concentrations of many dissolved and total trace constituents (table 10). The larger than background concentrations of trace constituents in samples from FLW-059 did not seem to be closely related to larger than background concentrations of major constituents. Background concentrations of trace constituents in the alluvium probably are larger than those in the bedrock, making the comparison of constituent concentrations in well samples from FLW-059 to background bedrock concentrations uncertain. In addition, the large concentrations of suspended solids contributed to the large concentrations of total trace constituents detected in samples from the temporary wells (table 10). Although the sample from TW 004 had background specific conductance and concentrations of major constituents, it contained the largest concentration of total VOCs $(24.2 \mu \mathrm{g} / \mathrm{L})$ detected in the temporary wells (table 11). The predominant VOCs detected were acetone $(17 \mu \mathrm{g} / \mathrm{L})$, chloroform $(4.6$ $\mu \mathrm{g} / \mathrm{L})$, dichloromethane and benzene $(0.6 \mu \mathrm{g} / \mathrm{L})$, and total xylenes $(0.3 \mu \mathrm{g} / \mathrm{L})$. Samples from TW 004 and TW 006 (near landfill 15) also contained trace concentrations (less than $0.5 \mu \mathrm{g} / \mathrm{L}$ ) of the freons chlorodifluoromethane (freon 22) and dichlorodifluoromethane (freon 12) (table 11). The VOC sample from TW 002 was broken during shipping.

The water table at FLW-059 is within the Roubidoux Creek alluvium and about 11 to $17 \mathrm{ft}$ below the land surface. The relative attitude of the water table using an assumed datum is shown in figure 22. Because of paucity of data and inability to install monitoring wells along the east and southern boundaries of the site, the water-table contours are only a general approximation of the water table at FLW-059. The general direction of shallow ground-water flow within the alluvium at FLW-059 is to the west and north toward Roubidoux Creek. Landfill FLW-059 is within a transition zone where Roubidoux Creek changes from a losing to a gaining stream. Discharge measurements made along Roubidoux Creek during 1995 indicate that upstream (south) from FLW-059, Roubidoux Creek generally is dry during the summer; however, less than $0.5 \mathrm{mi}$ downstream (northwest) from FLW-059, Roubidoux Creek contained a small flow $\left(0.2 \mathrm{ft}^{3} / \mathrm{s}\right)$ (Imes and others, 1996). Contaminants entering the bedrock beneath FLW-059 probably would emerge within Roubidoux Creek a short distance downstream from FLW-059 or at Roubidoux Spring, about 2.5 mi northwest of FLW059.

\section{Solid-Waste Management Unit FLW-060}

Solid-waste management unit FLW-060 (fig. 23) is a small landfill (less than 5 acres) southwest of road FLW 10 in the northeastern part of the FLWMR (fig. 2). It probably was used for the disposal of household wastes; however, no records of its use exist. The landfill is located between two small intermittent unnamed tributaries that flow into a tributary of the Big Piney River referred to as the Boy Scout tributary by Imes and others (1996). The surface of the site generally is flat with no visible depressions or subsidence features.

The USGS reconnaissance of the site included a review of historical aerial photographs taken during $1938,1955,1964,1967,1971,1974$, and 1986. The site appeared to be a pasture during 1938 , containing several small roads with trees along the margins of the northern and southern tributary (fig. 24). The site was disturbed and devoid of trees in the 1955 photograph with excavation and possibly refuse disposal occurring in the northeastern part (fig. 24). Refuse disposal appeared to proceed from north to south with the northern three-fourths of the site filled by 1964 (not shown), and all but the extreme southwestern part of the site filled by 1967 (fig. 24). The site appeared smooth with no visible excavation activity in the 1971, 1975, and 1986 aerial photographs (not shown) and vegetation gradually increased in density.

Field sampling at FLW-060 was conducted during 1995 and included the collection of 22 soil samples (combined in 5 composite samples), 2 streambed sedi- 


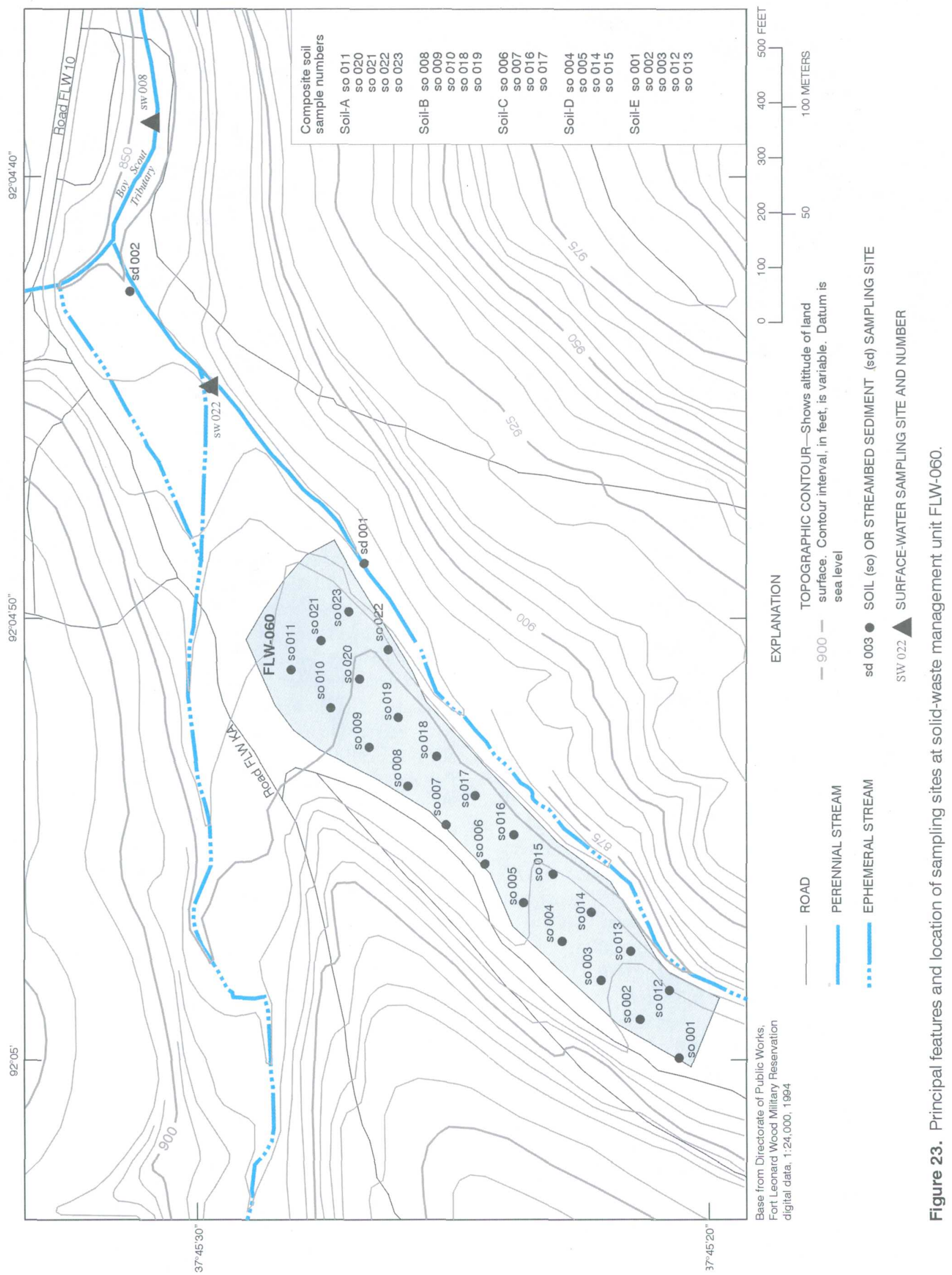



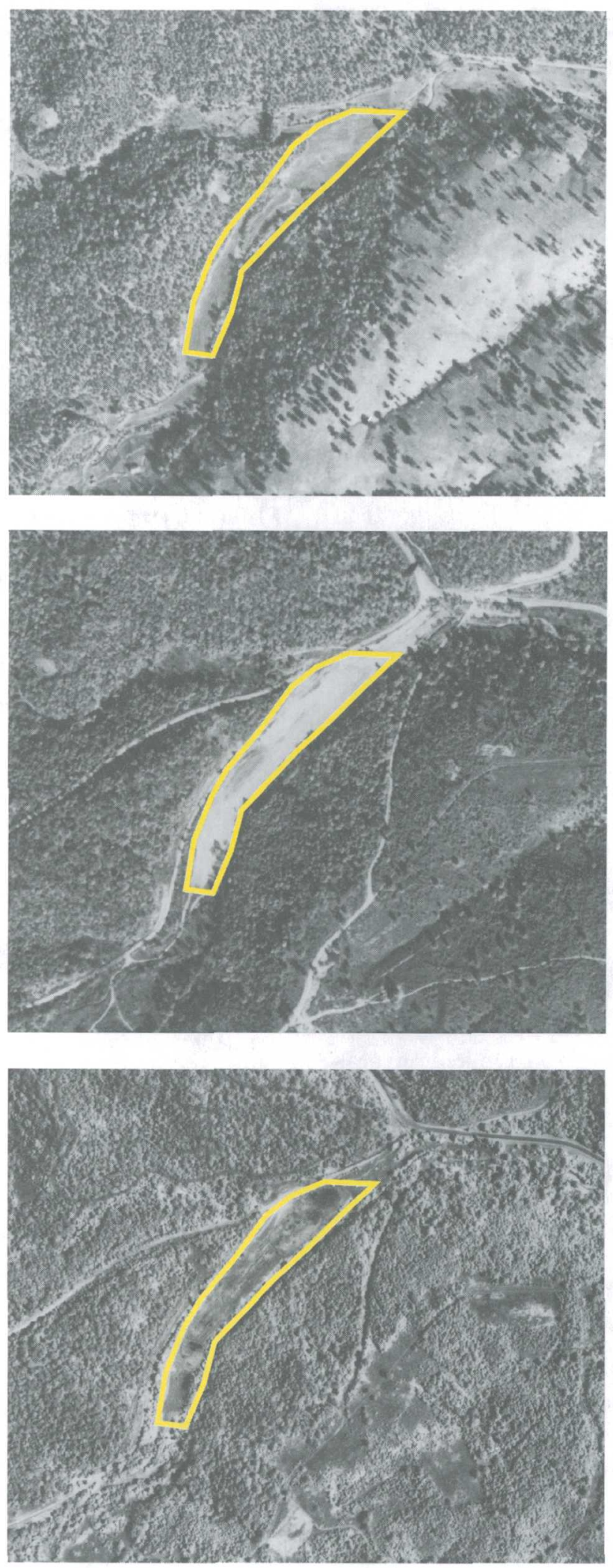

Figure 24. Aerial photographs of solid-waste management unit FLW-060 taken during 1938, 1955, and 1967. (Eastwest field of view is approximately 2,700 feet; top and middle photographs from Natural Resources Conservation Service; bottom photograph from U.S. Forest Service.) 
ment samples, and 1 surface-water sample (fig. 23). No seeps or springs were observed at the site. The streambed sediment samples were collected from the unnamed tributary that flows along the south side of the site. The surface-water sample was collected on June 14,1995 , from the south tributary downstream from FLW-060 and immediately upstream from its junction with the north tributary. The south tributary was dry upstream from FLW-060, but water began flowing in the tributary along the northern one-third of the site (fig. 23).

Compared to samples from other SWMUs at the FLWMR, soil samples from FLW-060 contained the smallest percent clay and among the largest concentrations of TOC, $\mathrm{Cu}, \mathrm{Pb}$, and $\mathrm{Mn}$ (fig. 14). The larger than expected TOC and trace element concentrations may be related to the surface of FLW-060 littered with small debris and its use for troop training activities. Concentrations of total carbon (TC), TOC, $\mathrm{Cu}, \mathrm{Mn}$, molybdenum (Mo), $\mathrm{Pb}$, and $\mathrm{Zn}$ were larger than background in one or more composite soil samples from the site (table 6). Streambed sediment samples from FLW-060 also contained small quantities of clay-size material compared to samples from other SWMUs (fig. 15), which probably is related to the steep gradient of the tributaries in this region of the FLWMR. Streambed sediment sample sd 001 contained larger than background concentrations of $\mathrm{Ce}(88 \mathrm{mg} / \mathrm{kg})$, and sample sd 002 contained larger than background concentrations of $\mathrm{Al}(7.4$ percent by weight), $\mathrm{P}(0.22$ percent by weight $), \mathrm{Cr}$ ( 77 $\mathrm{mg} / \mathrm{kg}$ ), and $\mathrm{Pb}(100 \mathrm{mg} / \mathrm{kg}$ ) (table 7). Optical mineralogy analysis of the non-magnetic heavy mineral concentrate in samples sd 001 and sd 002 detected no unusual minerals or anthropogenic contamination such as metallic $\mathrm{Pb}, \mathrm{Pb}$-rich glass fragments, or brass. Streambed sediment samples also contained trace concentrations (less than $1 \mu \mathrm{g} / \mathrm{kg}$ ) of DDT, DDD, DDE, dieldrin, and heptachlor epoxide and small concentrations of gross PCBs (2.6 and $5.5 \mu \mathrm{g} / \mathrm{kg}$ ) (table 8). Trace concentrations of the organophosphorus pesticides malathion and methyl-parathion (estimated concentrations of $0.1 \mu \mathrm{g} / \mathrm{kg}$ ) were detected in sample sd 002 .

The surface-water sample, sw 022 , collected downstream from FLW-060 had a specific conductance value $(472 \mu \mathrm{S} / \mathrm{cm})$ and concentrations of $\mathrm{Ca}, \mathrm{Ca}_{t}$, $\mathrm{HCO}_{3}, \mathrm{SO}_{4}, \mathrm{NO}_{2 \mathrm{t}}+\mathrm{NO}_{3 \mathrm{t}}, \mathrm{Ba}, \mathrm{Ba}_{\mathrm{t}}, \mathrm{B}, \mathrm{Pb}$, and $\mathrm{Sr}$ larger than background concentrations established by Imes and others (1996) for surface water at the FLWMR (table 12, at the back of this report). Although specific conductance and concentrations of several indicator constituents $\left(\mathrm{HCO}_{3}, \mathrm{NO}_{2 \mathrm{t}}+\mathrm{NO}_{3 \mathrm{t}}, \mathrm{B}\right.$, and $\left.\mathrm{Sr}\right)$ were larger than background, concentrations of other indicator constituents such as $\mathrm{Na}$ and $\mathrm{Cl}$ were not. Because the sample from sw 022 was collected near the beginning of flow in the southern tributary, the sample possibly may be more indicative of spring or ground-water quality; however, the concentrations of B $(90 \mu \mathrm{g} / \mathrm{L})$ and $\mathrm{Sr}(97 \mu \mathrm{g} / \mathrm{L})$ also were larger than background for ground water. Imes and others (1996) noted larger than background specific conductance values and concentrations of $\mathrm{Ca}$, total calcium $\left(\mathrm{Ca}_{\mathrm{t}}\right), \mathrm{Mg}, \mathrm{Mg}_{\mathrm{t}}, \mathrm{Na}, \mathrm{Na}_{\mathrm{t}}$, $\mathrm{HCO}_{3}, \mathrm{SO}_{4}, \mathrm{Cl}, \mathrm{B}, \mathrm{B}_{\mathrm{t}}$, and $\mathrm{Sr}$ in samples collected from the Boy Scout tributary (sw 008) downstream from FLW-060 (fig. 23) and indicated these could be related to runoff from the cantonment area, residential areas southwest of FLW-060, or FLW-060 itself. Sample sw 022 also had among the largest densities of fecal coliform $[270 \mathrm{col} / 100 \mathrm{~mL}$ (colonies per $100 \mathrm{millili}$ ters)] and fecal streptococcus ( $135 \mathrm{col} / 100 \mathrm{~mL}$ ) detected in surface-water sites near SWMUs (table 12). Based on the data available, the source of the larger than background specific conductance values and concentrations inorganic constituents in surface-water samples downstream from FLW-060 is equivocal.

Bedrock beneath FLW-060 is comprised of the Gasconade Dolomite which is exposed along the unnamed tributary south of the site (Harrison and others, 1996). No monitoring or water-supply wells are near FLW-060, and no ground-water data are available for the site. The regional water table in the vicinity of FLW-060 is within the upper Gasconade Dolomite at an altitude of about $800 \mathrm{ft}$ (fig. 2), or about $70 \mathrm{ft}$ below the land surface. Although the south tributary near the northern part of the site and the Boy Scout tributary north of the site were both observed to have flow during sampling visits in June, August, and October 1995, the regional water table is unlikely to intersect the stream channel adjacent to FLW-060. These tributaries probably are receiving inflow of shallow ground water from the adjacent hillsides. The regional water-table maps indicate the general direction of regional groundwater flow at FLW-060 is to the north; however, because of the proximity of the site to the Big Piney River (about 1 mi to the east), shallow ground water beneath the site probably flows to the northeast toward the river. 


\section{ORDNANCE DISPOSAL AND STORAGE UNITS}

Reconnaissance assessments were conducted at two ordnance disposal areas and an ammunition container storage area. The two ordnance disposal areas (FLW-030 and FLW-032) are in the southern part of the FLWMR (fig. 1). Activities at these sites involved the open burning/open detonation (OB/OD) and burial of spent ammunition and UXO. The ammunition container storage area (FLW-040) is part of a larger ammunition supply depot in the east-central part of the FLWMR.

\section{Solid-Waste Management Unit FLW-030}

Solid-waste management unit FLW-030 is less than $5,000 \mathrm{ft}^{2}$ (square feet) in size and located within Firing Range 24 about $5 \mathrm{mi}$ south of Forney Army Airfield, $0.5 \mathrm{mi}$ west of road FLW 1, and north of road FLW D in the south-central part of FLWMR (fig. 25). The site also is known as the 63rd and 543rd Explosive Ordnance Detachment (EOD) old OB/OD area. The site was operated as an $\mathrm{OB} / \mathrm{OD}$ area from an unspecified time until 1976 (PRC Environmental Management Inc., 1992). Since 1976, FLW-030 and surrounding area has been used for demolitions activities and is poorly vegetated. Wastes at FLW-030 may include unburned explosives or petroleum based fuels, residues remaining from burned explosives, and residues of burned petroleum-based fuels (U.S. Army Environmental Hygiene Agency, 1988a). The USAEHA conducted a site reconnaissance during 1990; however, no soil or ground-water samples were collected because active demolition training was occurring at Range 24 (PRC Environmental Management Inc., 1992).

Previous assessments have indicated that FLW030 is located south of road FLW D (U.S. Army Environmental Hygiene Agency, 1988a; PRC Environmental Management Inc., 1992); however, an extensive review of historical aerial photographs taken during $1938,1942,1955,1964,1967,1971,1976,1986$, and 1994 indicates the site probably is north of road FLW D. A comparison of the 1942 and 1955 aerial photographs shows disturbances north of road FLW D that can be attributed to OB/OD activities at FLW-030 (fig. 26). The 1955 photograph shows the presence of an earthen berm on the west side of the site and several depressions or pits where OB/OD activities may have occurred. By 1964, OB/OD activities were apparently being conducted as two distinct operations because two separate areas of disturbance that appear to be a pit are readily observable within the area outlined on figure 25. Little disturbance was observed in the 1967 and 1971 photographs; however, additional demolition training activity occurred in the area as evidenced by numerous pits or craters scattered across the site in the 1976, 1986, and 1994 aerial photographs (not shown).

The area encompassing FLW-030 has been used extensively for demolitions training since 1976 . No surface expression of the original FLW-030 site, the burn areas, or detonation pits remains. Because of the uncertainty in the exact location of the FLW-030 boundary and the potential to encounter buried UXO or demolitions training materials at this site, no soil samples were collected from this site. Two streambed sediment samples (sd 001 and sd 002) were collected from depositional areas near the upstream end of drainage culverts that extend beneath the gravel road north of the site. These samples were analyzed for grain size, inorganic constituents, SVs, and explosives. Neither of the streambed sediment samples contained detectable concentrations of explosives or SVs, indicating migration of detectable quantities of these compounds has not occurred from the site. Sediment samples from FLW030 contained among the largest mean concentrations of $\mathrm{Cu}$ and $\mathrm{Pb}$ (fig. 15) and small fragments of elemental $\mathrm{Pb}$ and brass were detected in this sample by optical mineralogy, indicating contamination from bullets and shell casings. Because of the multiple uses of the FLW030 site and surrounding area, the $\mathrm{Pb}$ and brass contamination cannot be directly attributed to FLW- 030 .

Two samples from surface-water sites sw 018 and sw 019 were collected from tributaries potentially receiving runoff to the south and the north of the site (fig. 25). Surface-water samples were analyzed for dissolved and total inorganic constituents, total nutrients, general pesticides, and explosives. Except for specific conductance and concentrations of a few major ions, the sample from sw 019 (north of FLW-030) generally had background values of physical properties and inorganic constituents and nutrients (table 12). The sample from sw 018 (south of FLW-030), however, had specific conductance values and concentrations of several major and trace inorganic constituents larger than background (table 12). Samples from sw 018 and sw 019 were collected from the upper reaches of the tributaries where flow first began and, therefore, may be more indicative of shallow ground-water quality. Concentrations of $\mathrm{Na}, \mathrm{Na}_{\mathrm{t}}, \mathrm{Cl}$, and $\mathrm{DS}$ (among other constituents) 


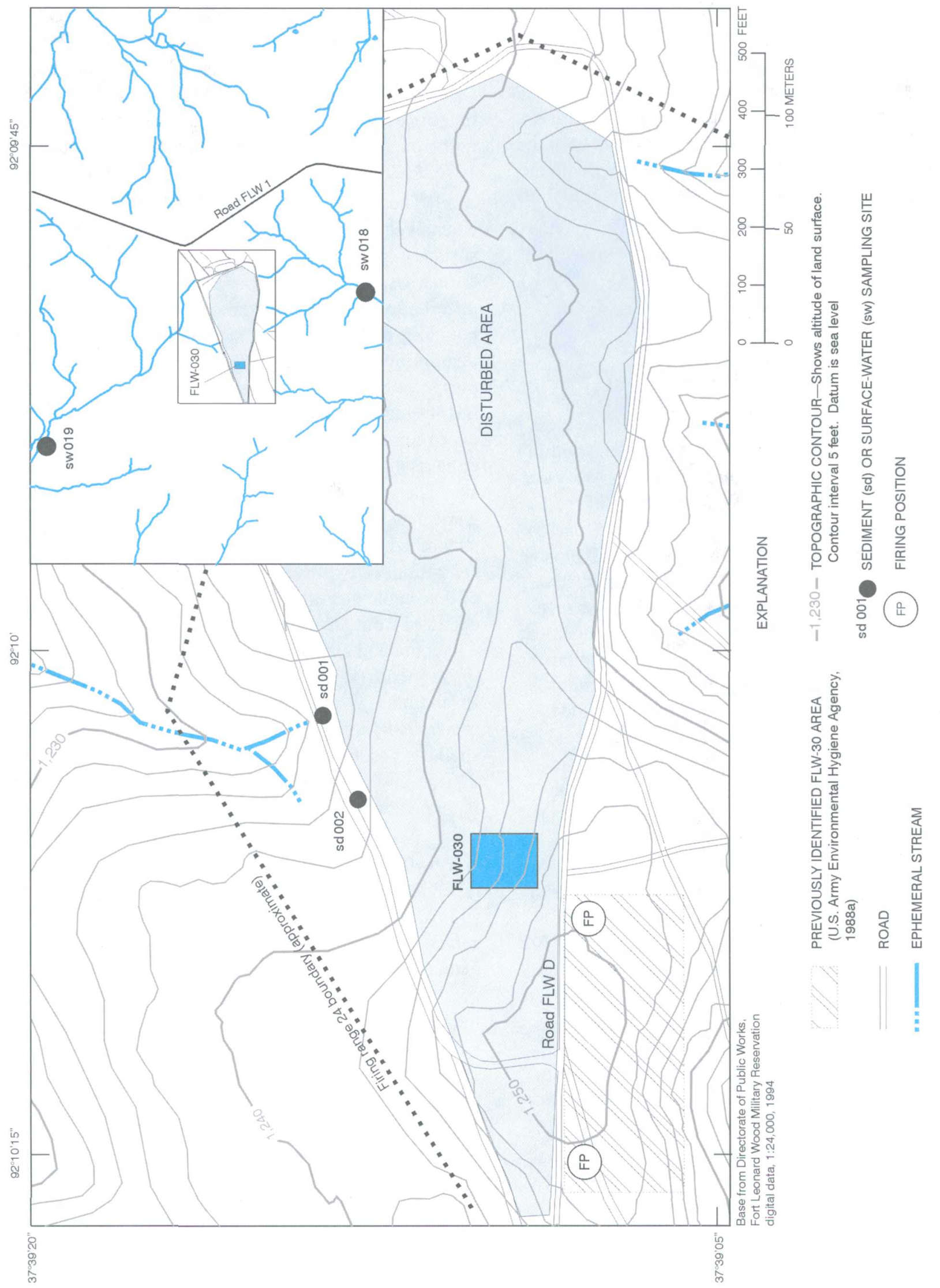

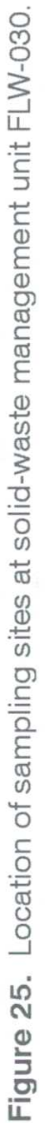




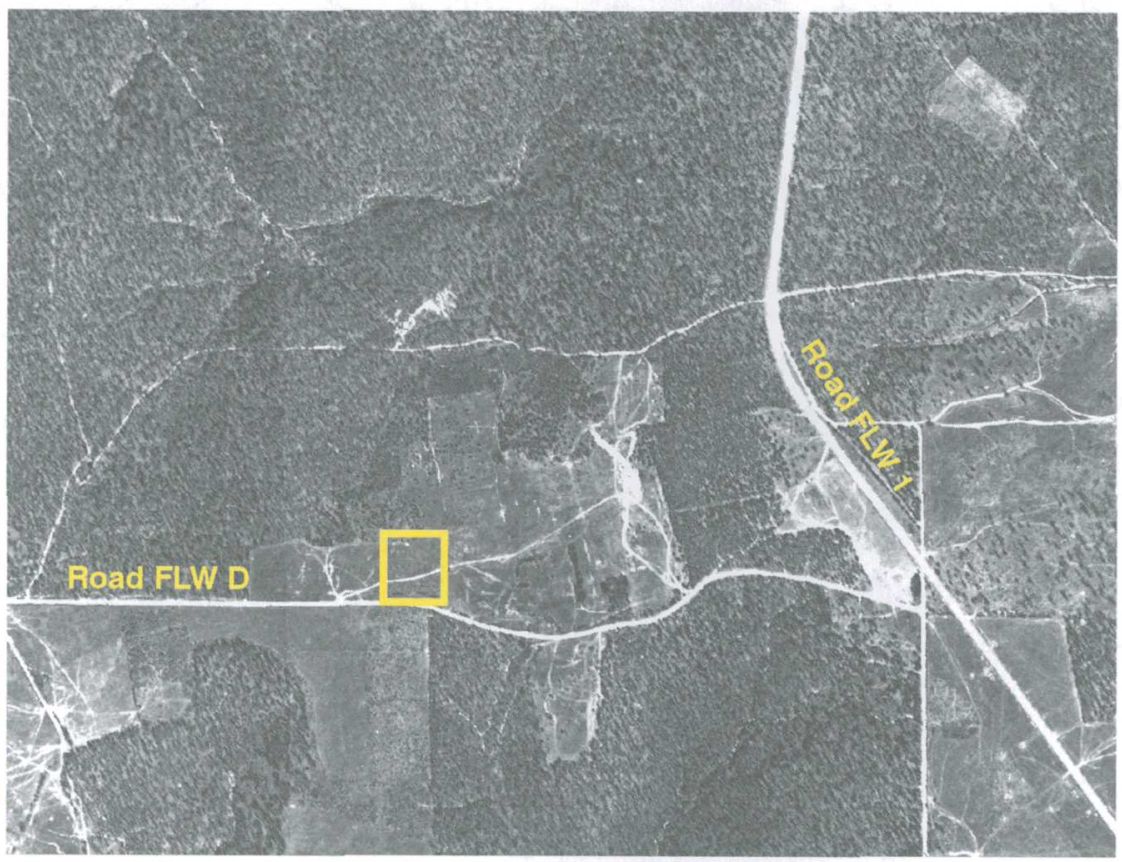

1955

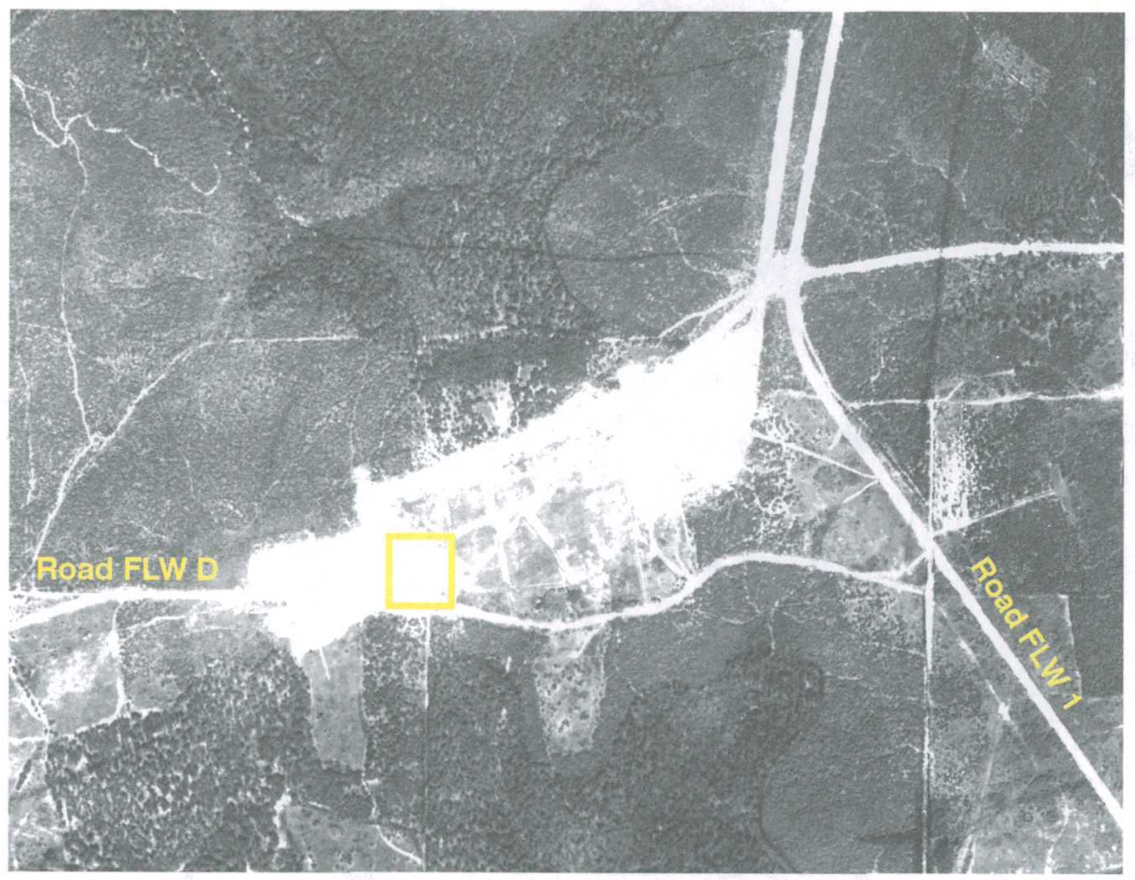

Figure 26. Aerial photographs of solid-waste management unit FLW-030 taken during 1942 and 1955. (East-west field of view is approximately 7,000 feet; photographs from U.S. Army Corps of Engineers.) 
in the sample from sw 018, however, were larger than background concentrations for ground-water samples, suggesting an anthropogenic source of $\mathrm{Na}$ and $\mathrm{Cl}$ such as road salt. Several small tributaries upstream from site sw 018 drains road FLW 1, which is a principal highway crossing the FLWMR. The sample from sw 019 contained trace concentrations of the herbicides atrazine [estimated at $3 \mathrm{ng} / \mathrm{L}$ (nanograms per liter)] and propanil (estimated at $3 \mathrm{ng} / \mathrm{L}$ ) and the pesticide carbaryl (estimated at $5 \mathrm{ng} / \mathrm{L}$ ) (table 11). The sample from sw 018 also contained trace concentrations of carbaryl (estimated at $6 \mathrm{ng} / \mathrm{L}$ ) and propanil (estimated at 2 $\mathrm{ng} / \mathrm{L}$ ). The detection of carbaryl is consistent with reported use of insecticides for control of ticks and other insects on training ranges at the FLWMR. The source of the trace concentrations of atrazine and propanil is unknown.

No monitoring or supply wells or springs were identified at the FLW-030 site or vicinity; therefore, no information exists on ground-water quality at the site. The altitude of the regional ground-water table in the vicinity of FLW-030 is about 1,000 ft (fig. 2) or about $245 \mathrm{ft}$ deep. According to Harrison and others (1996), the base of Roubidoux Formation in the vicinity of FLW-030 is at an altitude of $950 \mathrm{ft}$, indicating the regional water table is within the lower part of the Roubidoux Formation. Based on the regional water-table map (fig. 2), the anticipated direction of ground-water flow beneath FLW-030 is to the northwest.

\section{Solid-Waste Management Unơi FLWW-032}

Solid-waste management unit FLW-032 is at the ANG Cannon Range in the southwestern part of the FLWMR (fig. 1). The site is a few hundred feet northeast of the security gate at the west entrance of the Cannon Range (fig. 27). The Cannon Range opened during 1979 and, according to Cannon Range personnel, FLW-032 was used between 1982 and 1988 (Mike Cope, Senior Master Sergeant, Air National Guard Cannon Range, oral commun., 1997). Twice each year, personnel from the Cannon Range would collect undetonated practice bombs from the impact area and consolidate them in the open pit at FLW-032 for burning (U.S. Army Environmental Hygiene Agency, 1990). The bombs were burned with diesel fuel and scrap wood to deactivate the smoke charge (containing titanium tetrachloride) contained in the practice bombs. According to the USAEHA, the site actually is comprised of two small units (U.S. Army Environmental
Hygiene Agency, 1990)-a 100 by $15 \mathrm{ft}$ open-burn (OB) pit and a small burial pit (less than $1,000 \mathrm{ft}^{2}$ ) about $300 \mathrm{ft}$ west of the OB pit (fig. 28). After burning, the bomb cases were removed and placed in the burial pit. In 1998, spent practice bombs were checked by EOD personnel, and unexploded bombs are detonated and the fragments sold as scrap metal.

During a site visit in 1988 (U.S. Army Environmental Hygiene Agency, 1988a), the OB pit was described as a shallow trench (about $4 \mathrm{ft}$ deep) about 6 $\mathrm{ft}$ wide and $100 \mathrm{ft}$ long that was surrounded on three sides by an 8 -ft high earthen berm (fig. 28). The pit was partially filled with spent practice bombs, scrap metal, wood, and tires. Wastes at FLW-032 may contain explosives residues, titanium tetrachloride, titanium dioxide (produced from the reaction of titanium tetrachloride with water), and residue from diesel fuel. Other potential contaminants include trace elements and organic compounds derived from bomb casings and other debris, such as tires, that were observed in the OB pit during a 1988 site visit (PRC Environmental Management Inc., 1992). The USAEHA collected six soil samples from the $O B$ pit and vicinity for analyses of the explosives, total metals, and toxicity characteristics leaching procedure (TCLP) metals (fig. 28). None of the samples contained detectable concentrations of explosives, but a comparison to background concentrations of trace elements established in this study indicates USAEHA samples 2, 3, and 6 contained larger than background concentrations of As $(23.6,23.9$, and $31.9 \mathrm{mg} / \mathrm{kg}$ ) and sample 4 contained larger than background $\mathrm{Cr}$ concentrations $(128 \mathrm{mg} / \mathrm{kg})$. Because of the potential for buried UXO, no subsurface soil samples were collected (PRC Environmental Management Inc., 1992). A review of historical aerial photographs taken during 1971, 1976, 1986, and 1994 confirms that the Cannon Range and FLW-032 were not in operation during 1976 and that operations at FLW-032 had ceased by 1994 . In the 1986 aerial photograph, there appeared to be several dozen drums on the land surface immediately east of the $\mathrm{OB}$ pit.

The USGS conducted several site visits to FLW032 during 1995. The land surface at FLW-032 slopes to the north and east, and runoff from the site flows into an east flowing tributary and eventually into Roubidoux Creek about $0.5 \mathrm{mi}$ to the northeast (fig. 28).

Except for a clearing about $300 \mathrm{ft}$ wide (east-west) and $200 \mathrm{ft}$ long (north-south) containing scrap metal piles east of FLW-032, most of the area surrounding FLW032 is overgrown with weeds, brush, and small trees. 


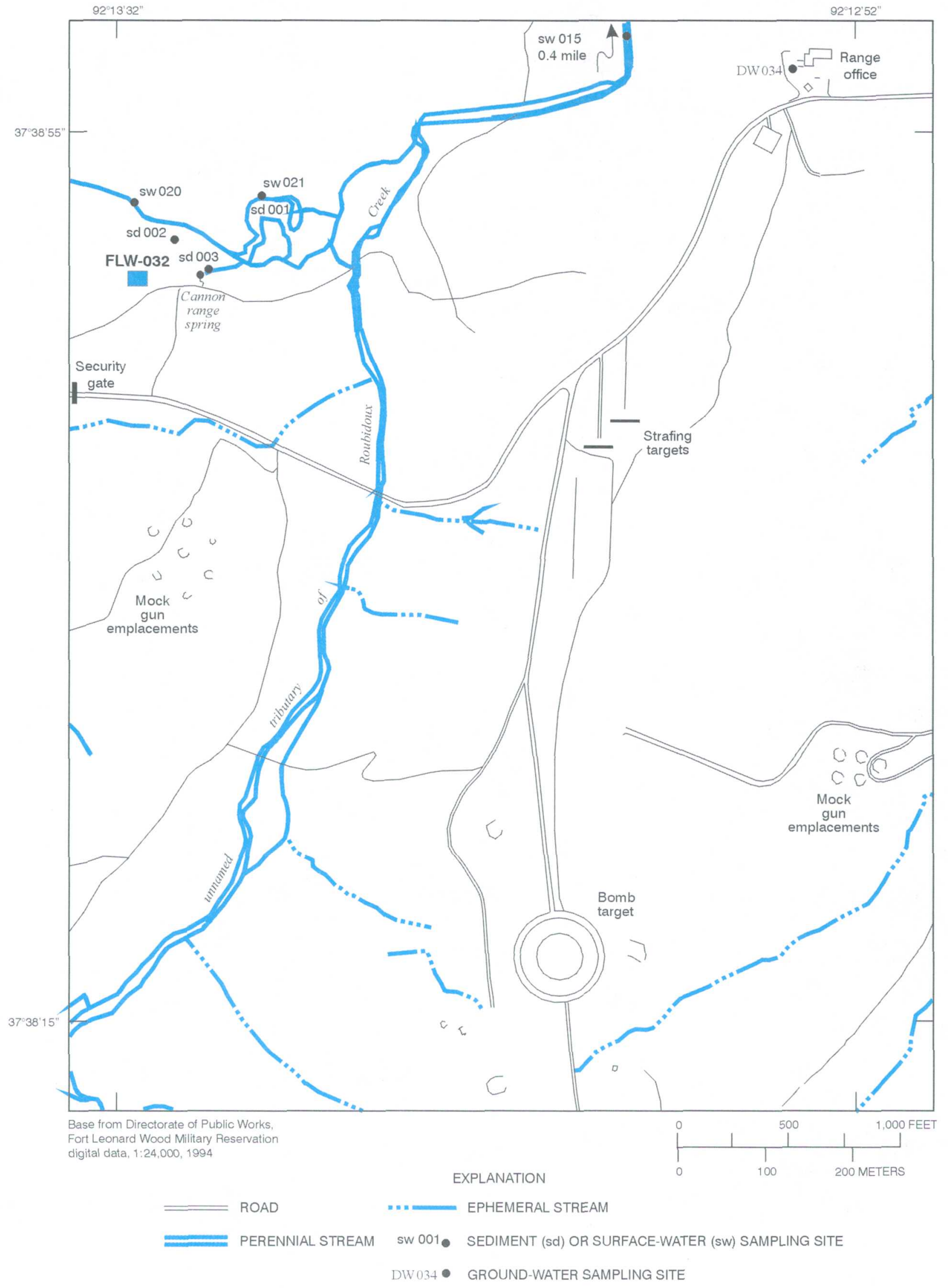

Figure 27. Principal features and location of sampling sites at solid-waste management unit FLW-032. 


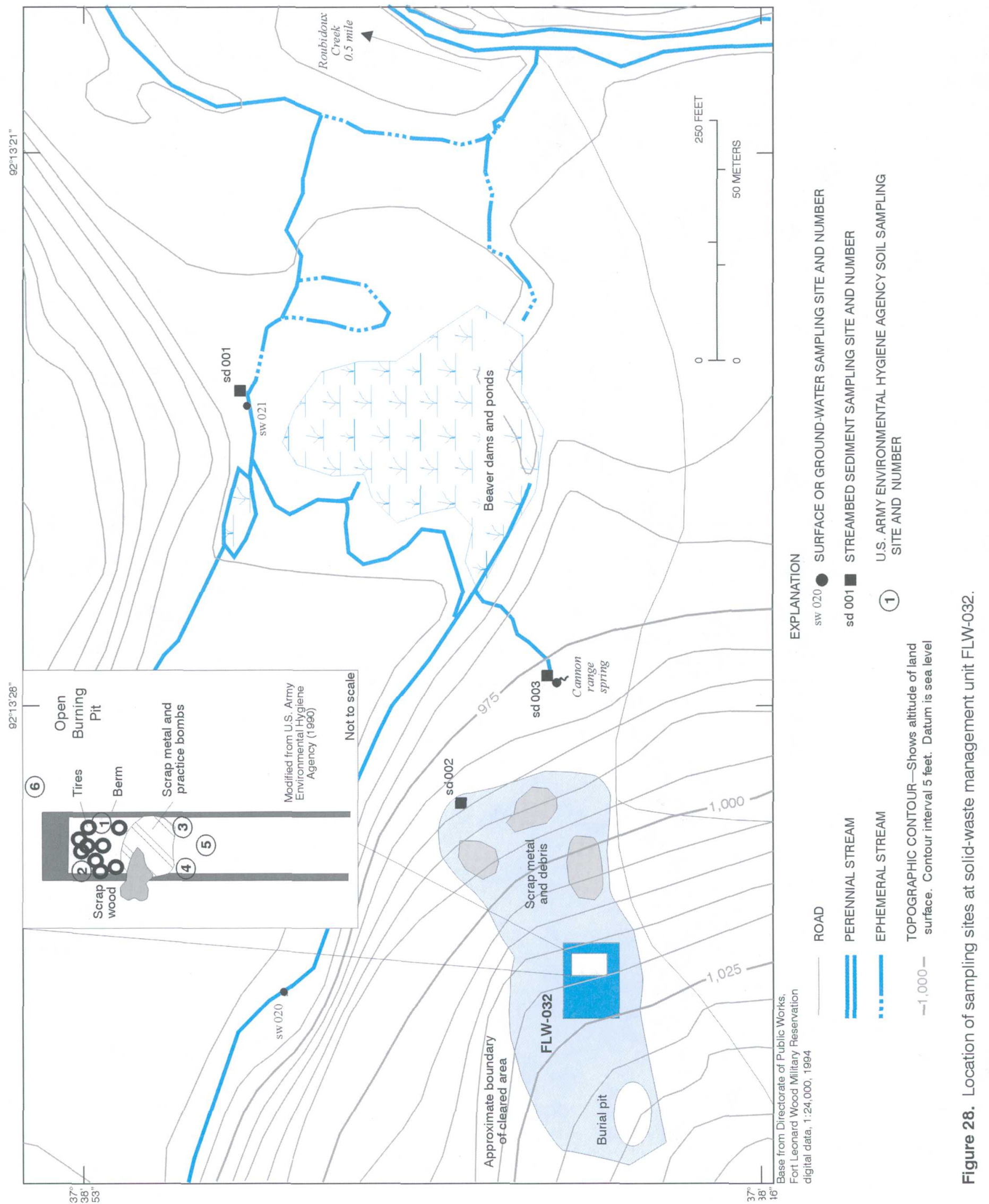


Stands of large trees are present to the north and east. Several signs warning of the potential for buried munitions marked the general boundary of FLW-032; however, the berm surrounding the $O B$ pit was not readily distinguishable. A small spring, referred to as the Cannon Range spring (Imes and others, 1996), emerges from the base of a large cottonwood tree several hundred feet east of FLW-032. No monitoring or domestic wells are at FLW-032, but a supply well for the Cannon Range is at the range office compound about $3,000 \mathrm{ft}$ east (fig. 27).

Because of the potential for encountering buried $\mathrm{UXO}$ at the site and uncertainty about the exact boundary of the $\mathrm{OB}$ pit and burial pit, no soil samples were collected at this site. During 1995, two surface-water samples (one upstream and one downstream) were collected from the unnamed tributary north of FLW-032 and analyzed for inorganic and organic constituents including explosives, semi-volatile organics, pesticides, and VOCs (table 2). Also, the primary tributary draining most of the Cannon Range was sampled near its mouth at Roubidoux Creek twice during 1995 as part of the regional geohydrologic assessment of the FLWMR (site sw 015, fig. 27). Discharge of the unnamed tributary north of FLW-032 at the upstream (sw 020) and downstream (sw 021) sites was $0.51 \mathrm{ft}^{3} / \mathrm{s}$. None of the surface-water samples contained larger than background concentrations of inorganic constituents that would indicate contaminant migration from FLW-032. In addition, none of the surface-water samples contained detectable concentrations of explosives, pesticides, SV, or VOCs (table 11).

Three streambed sediment samples were collected in the vicinity of FLW-032-one at the downstream surface-water site (sd 001), one from a dry gully downgradient from FLW-032 (sd 002), and one from the orifice of the Cannon Range spring (sd 003). In general, the sediment samples contained background concentrations of inorganic constituents (table 7). Some of the samples contained larger than background concentrations of $\mathrm{Ba}, \mathrm{La}, \mathrm{Nd}, \mathrm{Sr}$, or $\mathrm{Y}$; however, the concentrations were only slightly above background and did not exhibit a pattern consistent with anthropogenic contamination. None of the sediment samples contained detectable concentrations of explosives or SV. Sediment samples from FLW-032 had the smallest average clay contents of SWMU streambed sediment samples collected from FLWMR (fig. 15).
The results of ground-water samples from the vicinity of the site indicate no detectable contamination from FLW-032. Three ground-water samples were collected from the FLW-032 vicinity during 1995-one sample from the Cannon Range spring and two from the Cannon Range supply well at the range office ( $\mathrm{dw}$ 034, fig. 27). Analytical results from these samples were similar to those from ground-water samples from springs and wells at the FLWMR and vicinity as described by Imes and others (1996). Because of its proximity to FLW-032, the Cannon Range spring was thought to be a likely discharge point for FLW-032derived contaminants migrating through the shallow ground water. The sample from the Cannon Range spring had a specific conductance value $(393 \mu \mathrm{S} / \mathrm{cm})$ and concentrations of total beryllium $\left(\mathrm{Be}_{t}\right)(1.3 \mu \mathrm{g} / \mathrm{L})$ and $\mathrm{Mn}_{\mathrm{t}}(5 \mu \mathrm{g} / \mathrm{L})$ slightly larger than background (table 10). This sample also had concentrations of total cadmium $\left(\mathrm{Cd}_{t}\right)$, total cobalt $\left(\mathrm{Co}_{t}\right), \mathrm{Hg}_{\mathrm{t}}$, and total nickel $\left(\mathrm{Ni}_{\mathfrak{t}}\right)$ at the detection limit and no detectable concentrations of SV, pesticides, VOCs, or explosives.

Information on the depth and direction of ground-water flow and ground-water quality in the vicinity of FLW-032 is limited to data from the Cannon Range spring and the Cannon Range supply well. The altitude of the regional ground-water table in the vicinity of FLW-032 is about $960 \mathrm{ft}$ (fig. 2) or about $60 \mathrm{ft}$ below the land surface. Harrison and others (1996) mapped the base of the Roubidoux Formation in the vicinity of FLW-032 at an altitude of about $950 \mathrm{ft}$, indicating the regional water table is at or near the base of the Roubidoux Formation. Based on the regional water-table map, the anticipated direction of groundwater flow beneath FLW-032 is to the north or northeast. Roubidoux Creek in the vicinity of FLW-032 is a losing stream and probably does not affect groundwater flow near FLW-032. Perched water is located within the shallow bedrock in the vicinity of FLW-032 as evidenced by the presence of the Cannon Range spring. This spring is a likely discharge point for perched water beneath FLW-032.

\section{Solid-Waste Management Unit FLW-040}

Solid-waste management unit FLW-040 is a storage area that is used to temporarily store waste ammunition storage containers (U.S. Army Environmental Hygiene Agency, 1988a). The storage area is part of a 3-acre ammunition depot located east of road FLW 15 (fig. 29). The containers are constructed of metal or 


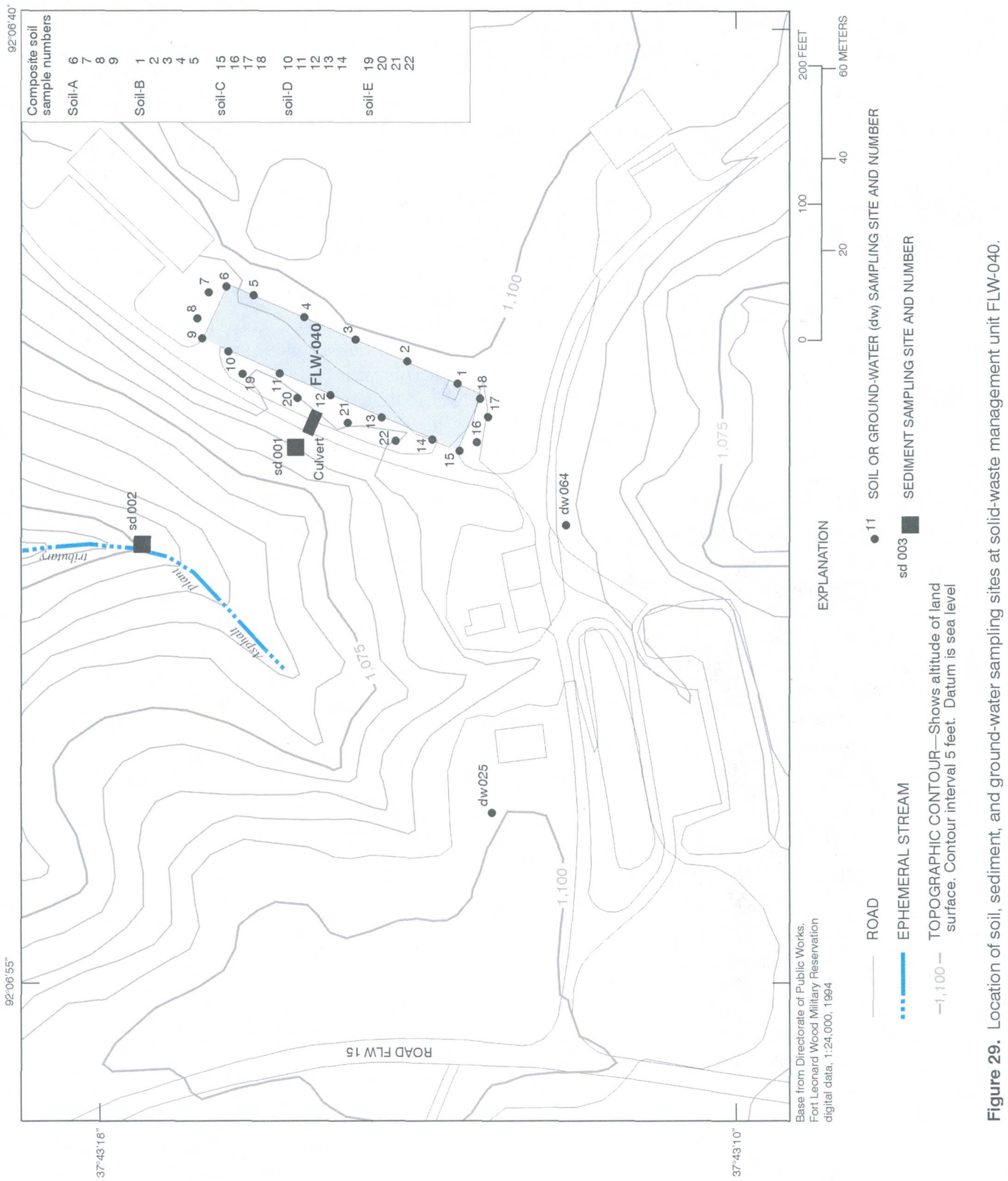


wood. Some of the wood ammunition storage containers have been treated with the wood preservative pentachlorophenol (PCP) and have been stored outside on a rectangular shaped concrete pad about $200 \mathrm{ft}$ long (PRC Environmental Management Inc., 1992). Laboratory analysis of samples from these containers indicate they contain PCP at concentrations of about 25 $\mathrm{mg} / \mathrm{kg}$. Non-PCP treated waste containers are stored directly on the ground. The metal and non-treated wood containers are accumulated and maintained by ammunition supply personnel until the FLWMR DRMO reuses the items or contracts to sell them. The ammunition supply point has been in operation since 1981, and PCP-treated ammunition storage containers have been stored at the facility since 1985 . The concrete pad and nearby ground-storage areas are not bermed or covered. Runoff from the site flows into the culvert beneath the perimeter access road where it is discharged onto a steep northwest facing hillside (fig. 29). The runoff subsequently drains into an unnamed tributary of the Big Piney River referred to as the asphalt plant tributary in this report. The asphalt plant tributary discharges into the Big Piney River about 1.5 mi east of FLW-040.

A site visit by the USEPA in September 1991 noted the presence of 17 pallets, each holding 32 PCPtreated waste ammunition storage containers (PRC Environmental Management, Inc., 1992). Although there were no documented reports of past spills or releases of $\mathrm{PCP}$ from the ammunition storage site, the USEPA concluded that airborne dust from "bloomed" (crystallized) PCP-treated materials and leached PCP from the storage area were possible mechanisms for mobilization of PCP. Drinking water for personnel working at the ammunition storage area is obtained from a nearby well.

The USGS conducted a review of historical aerial photographs and made field sampling visits of FLW-040 during the summer of 1995 and fall of 1997. A review of historical aerial photographs taken during 1986 and 1994 was inconclusive because the ammunition container area and concrete storage pad were too small to be distinguished. During the 1995 field sampling visit, several pallets of wooden ammunition storage containers and other containers holding spent brass shell casings and other materials were observed on the pad. Twenty-two soil samples (combined in 5 composite samples) were collected around the perimeter of the storage pad, and two streambed sediment samples were collected from dry tributaries downgradient of the stor- age pad (fig. 29). The soil and streambed sediment samples were submitted for analytical determinations of grain size, inorganic constituents, SV, and explosives. The split samples for the determination of SV were lost in shipment and resampling for these constituents by USEPA method 8270 was done in October 1997.

Analytical results of soil and streambed sediment samples indicate that migration of detectable quantities of SV (including PCP) or explosives from FLW-040 has not occurred. Soil samples from FLW040 contained background or near background concentrations of inorganic constituents (table 6). Concentrations of several constituents, such as $\mathrm{Al}, \mathrm{Fe}, \mathrm{As}, \mathrm{La}, \mathrm{Li}$, $\mathrm{Nd}, \mathrm{Ni}, \mathrm{Y}$, and ytterbium $(\mathrm{Yb})$ were slightly larger than background in composite samples B or D. The source of the larger than background constituent concentrations in the soil samples could be caused by subtle differences in mineralogy or anthropogenic sources (possibly activities at FLW-040). Because none of the composite soil samples contained sufficient quantities of material in the heavy mineral fraction to perform optical mineralogy, the source of the slightly larger than background constituent concentrations in samples $\mathrm{C}$ and $\mathrm{D}$ is equivocal. None of the soil samples collected during 1995 contained detectable concentrations of explosives, and none of the samples collected in October 1997 contained detectable concentrations of PCP.

Streambed sediment samples from FLW-040 contained among the largest mean $\mathrm{Zn}$ concentrations of the SWMUs sampled at the FLWMR (fig. 15). This large mean concentration was caused by a large $\mathrm{Zn}$ concentration $(500 \mathrm{mg} / \mathrm{kg})$ in sample sd 001 (table 7). The $\mathrm{Cu}$ concentration $(65 \mathrm{mg} / \mathrm{kg})$ in one bed sediment sample was slightly larger than the background of 61 $\mathrm{mg} / \mathrm{kg}$ (table 7). No other constituents were detected above background in the sediment samples, and the heavy mineral fraction contained insufficient material for optical mineralogy. The large $\mathrm{Zn}$ concentration in sd 001 probably is related to anthropogenic source such as galvanized metal. Neither of the streambed sediment samples contained detectable concentrations of SV or explosives.

Information on the depth and direction of ground-water flow and ground-water quality in the vicinity of FLW-040 is limited to data from the two supply wells (dw 025 and dw 064) at the site, the regional water-table map (fig. 2), and geologic mapping at the FLWMR (Harrison and others, 1996). Well 
$\mathrm{dw} 025$ was drilled to a depth of $450 \mathrm{ft}$ during the late 1970 's and was the original supply well for the ammunition depot (Rory McCarthy, oral commun., 1997). The length of surface casing in this well is unknown. Water from dw 025 became turbid after rainfall, indicating the well was open to fractures or solution cavities that were connected to the surface. Because of the turbidity in well dw 025 , the pump was removed and a new well (dw 064) was drilled nearby during 1995 (fig. 29). Well dw 064 was drilled to a total depth of $600 \mathrm{ft}$ and cased to a depth of $488 \mathrm{ft}$. The geologic log from this well indicates the top of the Eminence Dolomite was encountered at a depth of $395 \mathrm{ft}$. Because of lost circulation during drilling, the depth to the top of the Gasconade Dolomite is uncertain, but lies between 85 and $140 \mathrm{ft}$ below the land surface. Water levels measured in dw 025 ( 280.0 and $290.7 \mathrm{ft}$ below the land surface) and dw 064 (263.8 $\mathrm{ft}$ below the land surface) during 1995 indicate the regional water table beneath FLW-040 is $140 \mathrm{ft}$ or more below the top of the Gasconade Dolomite. The altitude of water in dw 064 was slightly higher than that in $\mathrm{dw} 025$, indicating an upward vertical hydraulic gradient that may be caused by intense karst features in the Gasconade Dolomite draining ground water rapidly away to nearby springs (Imes and others, 1996). Based on the regional watertable map, the anticipated direction of ground-water flow beneath FLW-040 is to the north-northeast; however, because FLW-040 is located near the boundary between the contributing recharge areas to Miller and Sandstone Springs, contaminants introduced into the shallow ground water could potentially emerge at either of these two springs.

Water-quality samples were collected from wells dw 025 and dw 064 during 1995 as part of the regional geohydrologic assessment of the FLWMR (Imes and others, 1996). Water samples from these wells were analyzed for major and trace inorganic constituents, nutrients, VOCs, SV, pesticides, and explosives (table 2). No VOCs, SVs, or pesticides were detected in samples from these wells. Values for physical properties and concentrations of most inorganic constituents and nutrients were less than background. The sample from $\mathrm{dw} 025 \mathrm{had}$ concentrations of $\mathrm{Cd}(2 \mu \mathrm{g} / \mathrm{L})$, total copper $\left(\mathrm{Cu}_{\mathrm{t}}\right)(20 \mu \mathrm{g} / \mathrm{L})$, and $\mathrm{Ag}(3 \mu \mathrm{g} / \mathrm{L})$ slightly larger than background and concentrations of $\mathrm{Zn}(660 \mu \mathrm{g} / \mathrm{L})$ and $\mathrm{Zn}_{\mathrm{t}}(690 \mu \mathrm{g} / \mathrm{L})$ substantially larger than background (table 10). The sample from dw 064 had larger than background concentrations of $\mathrm{Fe}_{\mathrm{t}}(750 \mu \mathrm{g} / \mathrm{L}), \mathrm{Mn}_{\mathrm{t}}(33$ $\mu \mathrm{g} / \mathrm{L})$, and $\mathrm{Ag}(2 \mu \mathrm{g} / \mathrm{L})$. The concentration of $\mathrm{Fe}_{\mathrm{t}}$ was above the Missouri secondary contaminant level established for $\mathrm{Fe}_{\mathrm{t}}$ of $300 \mu \mathrm{g} / \mathrm{L}$. The larger than background concentrations of inorganic constituents in these wells probably is related to leaching of these compounds from steel or galvanized well casings, pumps, or riser pipes and not the result of activities at FLW-040. Several gallons of household bleach were dumped in $\mathrm{dw}$ 064 after the pump was installed to disinfect the well; however, the bleach was allowed to sit in the well, resulting in corrosion of the steel well casing. The corrosion of the well casing causes water from the well to become turbid from rust after several days of non-use (Rory McCarthy, oral commun., 1997), and the corrosion probably contributes to the larger than background concentrations of $\mathrm{Fe}_{\mathrm{t}}, \mathrm{Mn}_{\mathrm{t}}$, and $\mathrm{Ag}$ detected in the sample from dw 064 .

Samples from wells dw 025 and dw 064 contained no detectable concentrations of SVs, pesticides, or explosives but did contain small concentrations ( 2.1 $\mu \mathrm{g} / \mathrm{L}$ total) of VOCs, thought to be the result of sample contamination from the $\mathrm{HCl}$ acid used in the preservation or well chlorination practices (Imes and others, 1996). None of the VOC or larger than background concentrations of inorganic constituents in either well can be directly attributed to activities at FLW-040.

\section{PETROLEUM, PESTICIDE, OR SOLVENT STORAGE FACILITIES}

\section{Solid-Waste Management Unit FLW-028}

Solid-waste management unit FLW-028 is an abandoned 100 - by $400-\mathrm{ft}$ fire training site located south of Forney Army Airfield in the central part of FLWMR. The site was operated from 1972 to 1988. Firefighting personnel used the site for emergency response firefighting training. Training occurred twice each year and involved the use of about 150 gal of aviation fuel for each training exercise (U.S. Environmental Hygiene Agency, 1988a). The fuel was placed on a concrete pad, which had berms to contain the fuel. Previous assessments (U.S. Army Environmental Hygiene Agency, 1990) indicated the concrete pad that served as the training area probably was removed; however, auger drilling during this assessment encountered concrete in several boreholes at a depth of $4 \mathrm{ft}$ near the middle part of the site (fig. 30). In 1998, the area was flat and contained unvegetated gravelly soil. The site is surrounded by earthen berms on three sides. The 


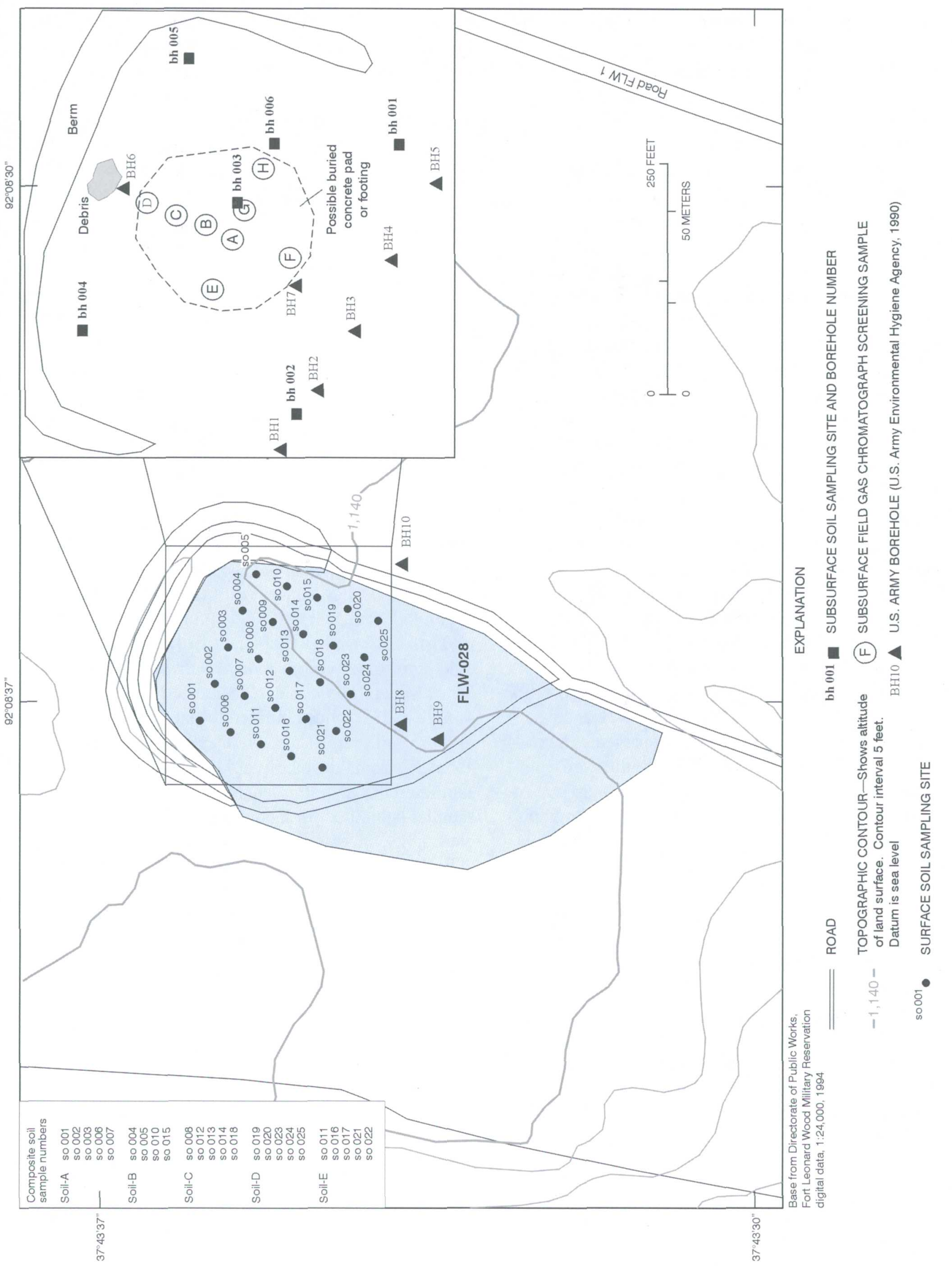

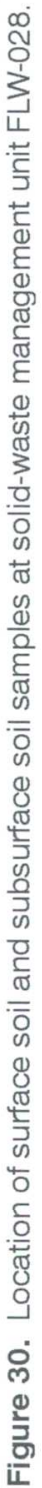


berms, constructed from soils excavated at the site, are about $6 \mathrm{ft} \mathrm{high}$ and $10 \mathrm{ft}$ wide on the north side and taper to ground level on the east and west sides. Discolored soils at FLW-028, indicative of fuel spills, were observed during a 1988 site visit (U.S. Army Environmental Hygiene Agency, 1990). Surface water drains from this area to an unnamed tributary that flows into the Big Piney River about $2 \mathrm{mi}$ to the east.

In 1988, the USAEHA drilled 10 boreholes at FLW-028, 7 of which were located inside of the berm area, to depths of about $10 \mathrm{ft}$ (fig. 30) (U.S. Army Environmental Hygiene Agency, 1990). Three soil samples from each borehole ( 2 to $3.5 \mathrm{ft}, 5$ to $6.5 \mathrm{ft}$, and 8 to 9.5 $\mathrm{ft}$ ) were analyzed for TCLP metals, total petroleum hydrocarbons (TPH), VOCs, and SVs. Methylene chloride $(6$ to $31 \mathrm{mg} / \mathrm{kg}$ ) and acetone (13 to $75 \mathrm{mg} / \mathrm{kg}$ ) were detected in samples from several boreholes, and the semi-volatile compound isophorone ( 850 to 2,130 $\mathrm{mg} / \mathrm{kg}$ ) was detected in all three samples from borehole bh 004 (U.S. Army Environmental Hygiene Agency, 1990). The detections of methylene chloride, acetone, and isophorone were attributed to laboratory contamination or misidentification.

Activities conducted by the USGS included a review of historical aerial photographs of FLW-028 and the surrounding area taken during 1967, 1971, 1976, 1986, and 1994. Considerable earth moving activity in the vicinity of FLW-028 (mainly to the west) was evident on the 1967 photograph; however, the concrete pad and earthen berms were not present. The concrete pad used for the fire training activities and a possible sump or depression along the northern part of the concrete pad were visible on the 1976 photograph. The earthen berms were visible on the 1986 and 1994 aerial photographs; however, the area inside the berms appeared to consist of unvegetated or poorly vegetated soil with no visible sign of the concrete pad.

The USGS collected 25 soil samples inside the bermed area in September 1995. The soil samples were composited in five composite samples and analyzed for grain size, inorganic constituents, and bulk mineralogy. Composite soil samples from FLW- 028 contained among the largest percentages of clay of the SWMU soil samples analyzed (fig. 14) (table 6). Concentrations of inorganic constituents were less than or only slightly larger than background.

A total of 14 shallow boreholes (less than $8 \mathrm{ft}$ deep) were drilled inside the bermed area using a soil exploration drill rig during September 1995. Only five boreholes were scheduled to be drilled (designated by the prefix "bh"); however, eight additional holes (designated by a single letter) were drilled near the middle of the bermed area to define the extent of a suspected buried concrete pad or footing. Boreholes A through $\mathrm{H}$ encountered refusal at $4 \mathrm{ft}$ on what appeared to be a smooth surface, possibly concrete (fig. 30 ). Boreholes drilled near the berm (bh 001, bh 002, bh 004, bh 005, and bh 006) did not encounter the suspected buried structure and were advanced to depths of between 6 and $8 \mathrm{ft}$. The upper 2 to $3 \mathrm{ft}$ of material encountered during drilling generally was an orange reddish-brown cherty clay. Beneath about $3 \mathrm{ft}$, the material generally was an orange plastic silty clay with weathered chert beds. In the middle of the site (letter designated boreholes), a noticeable increase in moisture was observed near the top of the suspected slab or footing.

During the drilling, a small soil sample ( 3 to $5 \mathrm{~g}$ ) was obtained directly from the bottom of the auger flights at depths of 3 and $6 \mathrm{ft}$ and analyzed for the presence of VOCs, including BTEX compounds, using a portable GC. Results of the field analyses were all negative except for the sample from borehole $G$, which showed the presence of benzene (estimated concentrations of $0.2 \mu \mathrm{g} / \mathrm{kg}$ ), toluene (estimated concentration of $1.5 \mu \mathrm{g} / \mathrm{kg})$, para-xylene $(2,000 \mu \mathrm{g} / \mathrm{kg})$, meta-xylene (50 $\mu \mathrm{g} / \mathrm{kg}$ ), ethylbenzene (not quantified), and various other unresolved compounds. A split sample was collected from this borehole (redesignated as borehole and sample bh 003) and submitted for laboratory analysis of SVs. Soil samples also were collected at depths of about $3 \mathrm{ft}$ from the other five " $\mathrm{bh}$ " series boreholes and submitted for laboratory analyses of SVs. None of the samples submitted for laboratory analyses contained detectable concentrations of SVs, indicating activities at FLW-028 have not resulted in widespread contamination of the shallow subsurface by fuels or petroleum products. However, small concentrations of VOCs are present in isolated areas.

No monitoring or supply wells are near FLW028. The closest wells to FLW-028 are the domestic wells at FLW-040 more than $1 \mathrm{mi}$ to the east (fig. 2). The altitude of the regional ground-water table in the vicinity of FLW-028 is about $890 \mathrm{ft}$ or about $250 \mathrm{ft}$ below the land surface. Based on the regional water table map, the anticipated direction of ground-water flow beneath FLW-032 is to the northeast. A number of sinkholes are in the vicinity of FLW-028 (fig. 4), and FLW-028 lies within a 1-mi wide northeast trending belt of intense sinkhole development (Imes and others, 1996). The site lies within the contributing recharge 
area for Shanghai Spring. The rapid (less than 4 days) travel time of dye injected into the sinkhole north of Forney Army Airfield to Shanghai Spring (traces T103-01, T103-16)(fig. 5) indicates that contaminants, if introduced into the subsurface in the vicinity of FLW028, may migrate rapidly through the subsurface and probably emerge at Shanghai Spring. No VOCs or SVs attributable to activities at FLW-028 have been detected at Shanghai Spring. Based on the available data, the lack of substantial subsurface contamination at FLW-028 makes potential contaminant releases from the site unlikely to measurably affect the ground-water quality beneath the site or at Shanghai Spring.

\section{Solid-Waste Management Unit FLW-037}

Solid-waste management unit FLW-037, formerly pesticide storage building 2206 , was in use from before 1966 to 1981 . The building was located in the northeastern part of the cantonment area near the junctions of road FLW 10 and road FLW K (fig. 31). The building was used to store and mix pesticides and pesticide rinsates. Drums of concentrated pesticide solutions were stored inside the building that had no secondary containment. Runoff from the site drains into an unnamed tributary that flows about $2.5 \mathrm{mi}$ to the east before entering the Big Piney River.

The wooden structure of building 2206 was demolished during 1996 and in 1998 only the concrete floor and sidewalks remain. The building was composed of two main rooms for the storage and mixing of pesticides and three smaller shower and wash rooms (fig. 32). During the 1970's, a 4-in. thick concrete cap was poured inside the mixing room on top of the original concrete slab. The original slab beneath the cap apparently was soaked with pesticide solutions, and the cap. was poured in an effort to control fumes emanating from the contaminated floor (Rory McCarthy, oral commun., 1994). The storage room and hallway with the water heater contained floor drains that were originally connected to the sanitary sewer system. An underground fuel oil tank was on the west side of the building, but had been removed at the time of the initial USGS reconnaissance in December 1994.

The U.S. Army conducted assessments at FLW037 during 1988, 1990, and 1992. During 1988, the U.S. Army indicated that some unused pesticide formulations or rinsates were disposed on the land surface at the northeast side of the building. During 1990, five soil samples ( 0 to $1 \mathrm{ft}$ deep) were collected from the east side of the building to determine if pesticides had been released outside the building. All of the soil samples contained concentrations of several organochlorine pesticides, such as DDD (as much as 15,000 $\mu \mathrm{g} / \mathrm{kg}$ ), DDE (as much as $43,000 \mu \mathrm{g} / \mathrm{kg}$ ), and DDT (as much as $220,000 \mu \mathrm{g} / \mathrm{kg}$ ) (U.S. Army Environmental Hygiene Agency, 1990). Samples were not analyzed for other pesticides such as organophosphate insecticides, carbamates, triazine herbicides, and chlorophenoxy-acid herbicides. During 1992, the U.S. Army conducted a survey of the interior walls of the building to determine if the surfaces were contaminated prior to demolishing the building. The survey consisted of collecting 43 wipe samples from interior surfaces. Large concentrations of chlordane, DDD, DDE, and DDT were detected in wipe samples from walls and floors in the storage and mixing rooms and from hallways near the showers, indicating that interior surfaces were contaminated. Because the interior surfaces were contaminated, demolition of the structure was postponed until further characterization was done.

The USGS assessment at FLW-037 was conducted in three phases. The initial reconnaissance of the building was conducted in December 1994. During this visit, visible staining of the lower parts of the west interior wall in the mixing room and a thick oily residue coating the exhaust fan blades and housing were observed. The phase I assessment focused on additional characterization of the building materials and adjacent surficial soils. At the request of the U.S. Army, the USGS prepared a sampling plan during early 1995 to determine if the materials comprising building 2206 exhibited characteristics of a hazardous waste as described in 40 Code of Federal Regulations (CFR) part 261.20. A rectangular grid was marked on the inside walls ( $2 \mathrm{ft}$ by $2 \mathrm{ft}$ ) and ceilings ( $4 \mathrm{ft}$ by $6 \mathrm{ft}$ ) of each room in the building. Subsamples were collected from the center of each grid using a portable drill and 1.5-in. diameter key-hole bit. Subsamples from exterior wood siding or framing members were collected using a spade-type drill bit, and subsamples from the exhaust fan blades and motor housing were collected using a small stainless steel spatula to scrape the surfaces. The subsamples were composited into eight samples that were submitted to a contract laboratory for analysis of ignitability, corrosivity, reactivity, and TCLP pesticides and herbicides listed in 40 CFR part 261.24. In addition, composite samples 5, 7, and 8 also were analyzed for total pesticides and PCBs, many of which are not included on the TCLP list (table 13). 


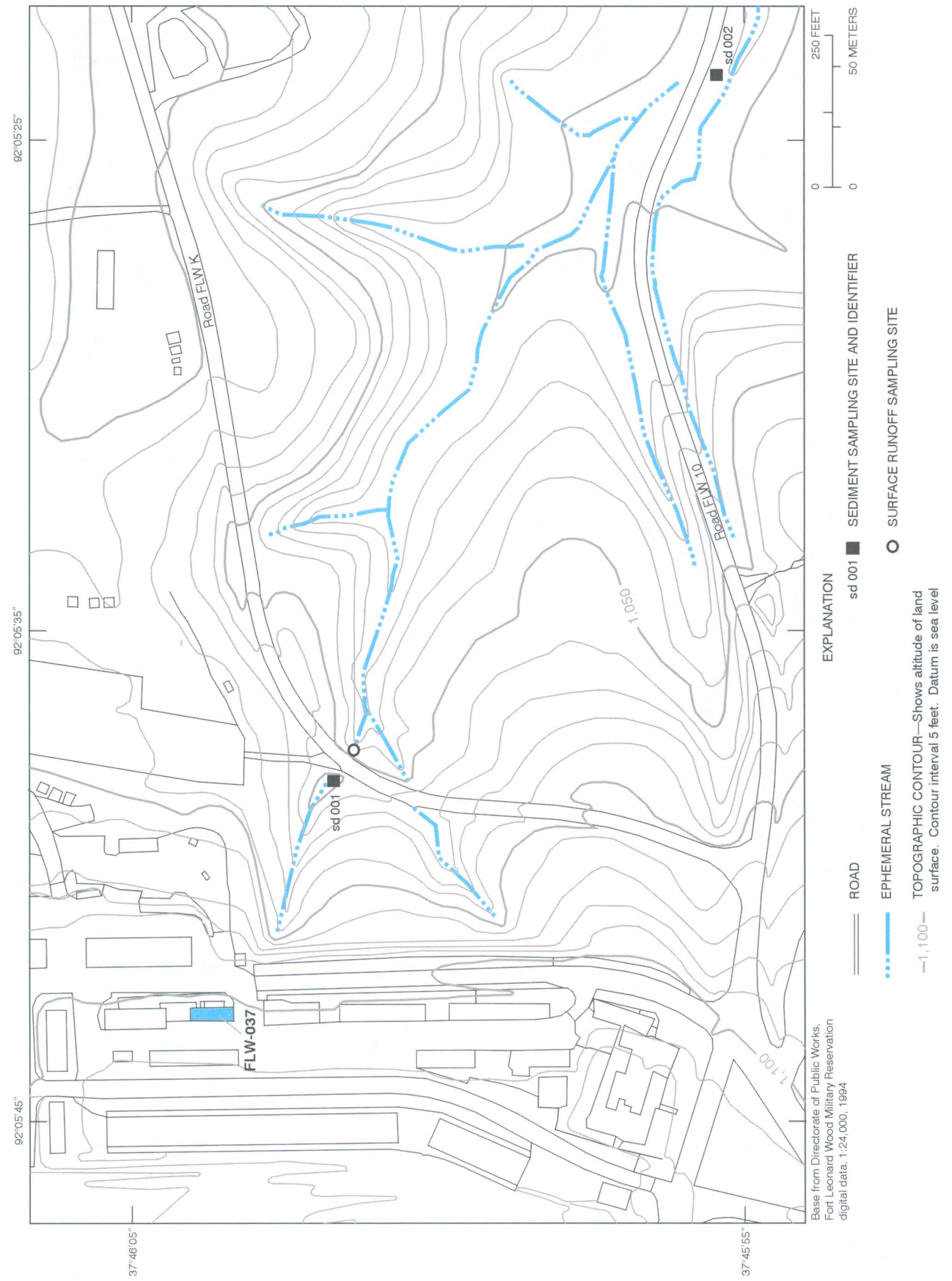

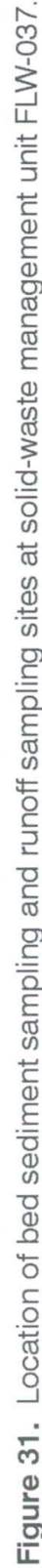




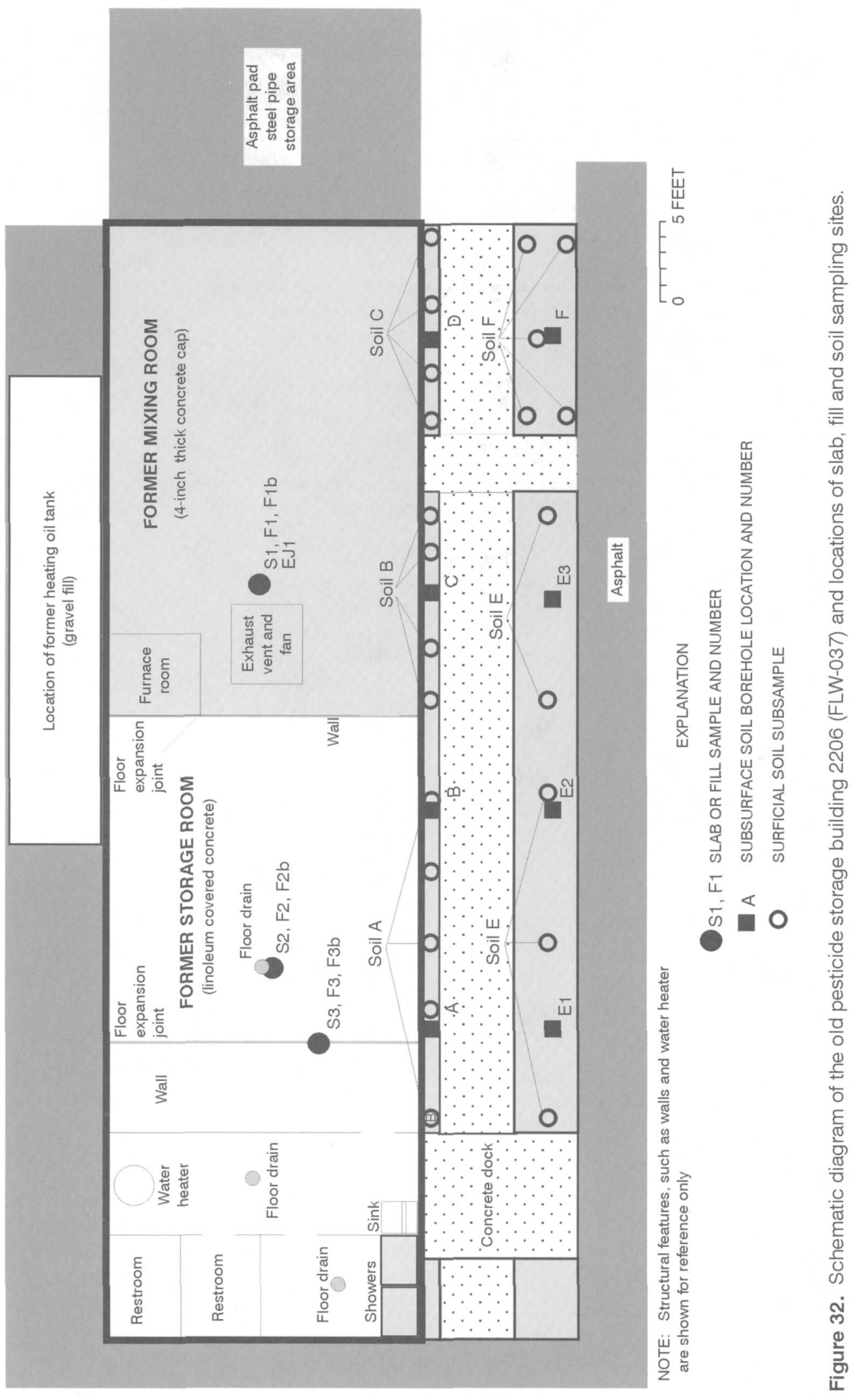


Table 13. Reporting limits for characteristics and selected pesticides determined in building material samples from solid-waste management unit FLW-037

[USEPA, U.S. Environmental Protection Agency; CFR, Code of Federal Regulation; --, no data]

\begin{tabular}{lclc}
\hline $\begin{array}{c}\text { Characteristic or } \\
\text { compound }\end{array}$ & Reporting limit & \multicolumn{1}{c}{ Reporting limit units } & $\begin{array}{c}\text { USEPA method } \\
\text { number }\end{array}$ \\
\hline Ignitability, flash point & 200 degrees & Degrees Fahrenheit & 1010 \\
Corrosivity, pH value & 0.01 & Standard units & 9040 \\
$\begin{array}{l}\text { Reactivity } \\
\text { sulfides, reactive } \\
\text { cyanides, reactive }\end{array}$ & 10 & Milligrams as sulfur per kilogram & 7.3 \\
& .02 & Milligrams as cyanide per kilogram & 7.3
\end{tabular}

$\begin{array}{lclr} & \text { Toxicity characteristics leaching procedure (TCLP) pesticides (40 CFR part 261.24) } \\ \text { Chlordane } & 0.8 & \text { Micrograms per liter } & 8080 \\ \text { 2,4-D } & 7 & \text { Micrograms per liter } & - \\ \text { 2,4,5-TP } & 7 & \text { Micrograms per liter } \\ \text { Endrin } & .08 & \text { Micrograms per liter } & -- \\ \text { Hepatchlor } & .08 & \text { Micrograms per liter } & 8080 \\ \text { Heptachlor epoxide } & .08 & \text { Micrograms per liter } & 8080 \\ \text { Lindane (gamma-BHC) } & .08 & \text { Micrograms per liter } & 8080 \\ \text { Methoxychlor } & 1.5 & \text { Micrograms per liter } & 8080 \\ \text { Toxaphene } & 1.6 & \text { Micrograms per liter } & 8080\end{array}$

2,4-D
$2,4,5-T P$
Aldrin
alpha-BHC
beta-BHC
delta-BHC
Chlordane
DDD
DDE
DDT
Dieldrin
Endosulfan I
Endosulfan II
Endosulfan sulfate
Endrin
Endrin aldehyde
Heptachlor
Heptachlor epoxide
Lindane (gamma-BHC)
Methoxychlor
Toxaphene

\section{Total non-TCLP pesticides}

Micrograms per kilogram $\quad 8080$

Micrograms per kilogram $\quad 8080$

Micrograms per kilogram $\quad 8080$

Micrograms per kilogram $\quad 8080$

Micrograms per kilogram $\quad 8080$

Micrograms per kilogram $\quad 8080$

Micrograms per kilogram $\quad 8080$

Micrograms per kilogram $\quad 8080$

Micrograms per kilogram $\quad 8080$

Micrograms per kilogram $\quad 8080$

Micrograms per kilogram $\quad 8080$

Micrograms per kilogram $\quad 8080$

Micrograms per kilogram $\quad 8080$

Micrograms per kilogram $\quad 8080$

Micrograms per kilogram $\quad 8080$

Micrograms per kilogram $\quad 8080$

Micrograms per kilogram $\quad 8080$

Micrograms per kilogram $\quad 8080$

Micrograms per kilogram $\quad 8080$

Micrograms per kilogram $\quad 8080$

Micrograms per kilogram $\quad 8080$

\begin{tabular}{llll} 
Aroclor-1016 & 80 & Micrograms per kilogram & 8080 \\
Aroclor-1221 & 80 & Micrograms per kilogram & 8080 \\
Aroclor-1232 & 80 & Micrograms per kilogram & 8080 \\
Aroclor-1242 & 80 & Micrograms per kilogram & 8080 \\
Aroclor-1248 & 80 & Micrograms per kilogram & 8080 \\
Aroclor-1254 & 80 & Micrograms per kilogram & 8080 \\
Aroclor-1260 & 80 & Micrograms per kilogram & 8080 \\
\hline
\end{tabular}

Results of the TCLP characterization of the building materials are listed in table 14 , at the back of this report. None of the composite samples exhibited any characteristics of a hazardous waste. Small concentrations of reactive cyanides were detected in compos- ite sample $1(0.039 \mathrm{mg} / \mathrm{kg})$ and composite sample 3 $(0.035 \mathrm{mg} / \mathrm{kg})$. The concentrations, however, were not sufficient to present a significant danger to human health or the environment (40 CFR part 261.23). Composite samples 5,7 , and 8 contained detectable concen- 
trations of two non-TCLP pesticides; $2,4-\mathrm{D}$ (60 to $1,100 \mu \mathrm{g} / \mathrm{kg})$ or $2,4,5-\mathrm{TP}(40 \mu \mathrm{g} / \mathrm{kg})$ (table 14). These compounds, however, were not detected in the TCLP extracts. Because none of the composite samples exhibited any characteristics of a hazardous waste, the wooden building structure was subsequently demolished during 1998.

Composite soil samples (samples A-F, fig. 32) collected east of the existing building slab contained large concentrations of chlordane (250 to $1,400 \mu \mathrm{g} / \mathrm{kg}$ ), DDT (410 to greater than $33,000 \mu \mathrm{g} / \mathrm{kg}$ ), DDD (56 to $800 \mu \mathrm{g} / \mathrm{kg}$ ), DDE (380 to less than $7,700 \mu \mathrm{g} / \mathrm{kg}$ ), and dieldrin $(29$ to $1,100 \mu \mathrm{g} / \mathrm{kg})$. Smaller concentrations of aldrin, heptachlor, heptachlor epoxide, and lindane also were detected (samples A-F, table 8). All of the samples contained detectable concentrations of gross PCBs $(13.4$ to $120 \mu \mathrm{g} / \mathrm{kg}$ ) and the organophosphorus pesticides malathion ( 1.3 to $170 \mu \mathrm{g} / \mathrm{kg}$ ) and diazinon ( 0.5 to $3.6 \mu \mathrm{g} / \mathrm{kg}$ ). Sample $C$ also contained a trace quantity of methyl parathion (estimated concentration of 0.1 $\mu \mathrm{g} / \mathrm{kg}$ ). Sample D was broken during shipment. The predominance of the organochlorine pesticides in the soils reflects their usage at the FLWMR and their resistance to degradation compared to other pesticides.

Phase II of the USGS assessment was to determine if the remaining building slab and underlying fill materials contained hazardous concentrations of pesticides. A sampling plan was prepared and field work was conducted during December 1996. Eight samples were collected from the concrete slab and underlying fill, the expansion joint in the original mixing room floor, and the linoleum floor covering on the exposed former storage room slab. Before sampling, a hammer drill and sledge hammer were used to remove a $2-\mathrm{ft}^{2}$ section of the concrete cap overlying the original mixing room slab in an area where an expansion joint was thought to be located. The upper 0.5 to $1 \mathrm{in}$. of the original slab over a $1-\mathrm{ft}^{2}$ area was sampled in three areas (samples S1, S2, and S3) using a chisel and hammer (fig. 32). Sampling was bias toward areas of the original slab that appeared stained. The expansion joint beneath the former mixing room (sample EJ1) was sampled using a stainless steel spatula. After the collection of the slab and expansion joint samples, the slab was broken and removed to expose the underlying gravelly clay fill. The upper $1 \mathrm{in}$. of the fill was removed and the underlying fill material was sampled using a stainless steel trowel (samples F1, F2, and F3). About 30 random subsamples of the linoleum floor covering from the former storage room were collected using a putty knife and composited (sample L1). All samples were submitted to a contract laboratory for analyses of hazardous characteristics and TCLP pesticides (table 13).

Except for small concentrations of the herbicide 2,4-D that were detected in TCLP extracts from the samples EJ1 $(28 \mu \mathrm{g} / \mathrm{L})$ and $\mathrm{Fl}(16 \mu \mathrm{g} / \mathrm{L})$, none of the TCLP extracts had detectable concentrations of pesticides (table 14). These concentrations of 2,4-D were substantially smaller than the maximum regulatory level of $10 \mathrm{mg} / \mathrm{L}$, indicating that the slab and underling fill cannot be classified as hazardous wastes based on the TCLP. Because the TCLP test is designed to determine if a material is a hazardous waste and not to characterize the environmental concentrations of constituents, additional samples of the fill at locations 1, 2, and 3 (F1b, F2b, F3b) were collected in July 1997 and submitted to the USGS laboratory for the determination of total concentrations of organochlorine pesticides. Results of these samples contrast dramatically with the results of the TCLP tests and indicate the presence of large concentrations of chlordane (4,000 to $45,000 \mu \mathrm{g} / \mathrm{kg}$ ), DDT (270 to $280,000 \mu \mathrm{g} / \mathrm{kg}$ ), DDD (19 to $27,000 \mu \mathrm{g} / \mathrm{kg}$ ), DDE (15 to $24,000 \mu \mathrm{g} / \mathrm{kg}$ ), dieldrin (21 and 5,100 $\mu \mathrm{g} / \mathrm{kg}$ ), and heptachlor (57 to 1,000 $\mu \mathrm{g} / \mathrm{kg}$ ). Sample F $2 \mathrm{~b}$ also contained aldrin at $22 \mu \mathrm{g} / \mathrm{kg}$ (table 8). The largest concentrations were detected in samples F2b and F3b that were collected from the fill beneath the slab near the storage room floor drain and expansion joint. Results of these analyses indicate that, although the none of the slab or underlying fill samples can be classified as hazardous wastes based on the TCLP tests, the fill samples contain substantial quantities of organochlorine pesticides.

Phase III of the USGS assessment focused on determining the extent and magnitude of subsurface soil contamination immediately east of the building slab. A sampling plan was developed and conducted in February 1997. A CME-55 drill rig was used to collect subsurface samples from locations previously sampled during 1995 (fig. 32). Samples were collected using a 3-in. diameter stainless steel split spoon sampler. To minimize disturbance of the soils and minimize the volume of cuttings to be drummed, the split spoon sampler was not advanced with auger flights. The sampling program called for the collection of samples from depths of $0,1,2,3,5$, and $7 \mathrm{ft}$; however, because of the presence of weathered chert beds of the Roubidoux Formation residuum in the shallow subsurface, only borehole $\mathrm{F}$ reached the target depth of $7 \mathrm{ft}$ (table 15). The samples were submitted to the USGS laboratory for analysis of organochlorine pesticides. Because 
concentrations of organophosphorus and chlorophenoxy-acid herbicides were small compared to the organochlorine pesticides in the previously collected surficial soil samples, these compounds were not ana- lyzed in the subsurface samples. To minimize the sampling costs, only two samples from each hole were initially submitted for laboratory analyses. The remaining samples were archived at $4{ }^{\circ} \mathrm{C}$.

Table 15. Subsurface soil samples collected from solid-waste management unit FLW-037

[Underlining indicates the sample was submitted for laboratory analysis]

\begin{tabular}{|c|c|c|c|c|c|c|c|c|}
\hline Description & Borehole A & Borehole B & Borehole C & Borehole D & Borehole E1 & Borehole E2 & Borehole E3 & Borehole F \\
\hline $\begin{array}{l}\text { Total depth, } \\
\text { in feet below } \\
\text { land surface }\end{array}$ & 5.0 & 3.0 & 2.2 & 5.0 & 4.0 & 3.0 & 5.5 & 7.0 \\
\hline $\begin{array}{l}\text { Sample number } \\
\text { and interval, } \\
\text { in feet below } \\
\text { land surface }\end{array}$ & $\begin{array}{l}\mathrm{A} 0.0-0.5 \\
\mathrm{~A} 1,1.0-1.5 \\
\mathrm{~A} 2.2 .0-2.5 \\
\mathrm{~A} 3,3.1-3.5\end{array}$ & $\begin{array}{l}\text { B0,0-0.5 } \\
\text { B1, 1.0-1.5 } \\
\text { B2.5.2.5-2.9 }\end{array}$ & $\frac{\mathrm{c} 0.0-0.5}{\mathrm{c} \cdot 1.0-1.5}$ & $\begin{array}{l}\mathrm{D} 0,0-0.5 \\
\mathrm{D} 1,1.0-1.5 \\
\mathrm{D} 2.5,2.5-3.0\end{array}$ & $\frac{\text { El-0.0-0.5 }}{\text { E1-1,1.0-1.5 }}$ & $\begin{array}{l}E 2-0,0-0.5 \\
E 2-1,1.0-1.5 \\
E 2-2,2.2-2.5\end{array}$ & $\begin{array}{l}\text { E3-0.0.2-0.7 } \\
\text { E3-1, 1.0-1.5 } \\
\text { E3-2.2.0-2.5 } \\
\text { E3-3,3.0-3.5 }\end{array}$ & $\begin{array}{l}\frac{F 0.0-0.5}{F 1,1.0-1.5} \\
\frac{F 2.2 .0-2.5}{F 3,3.0-3.5} \\
F 5,5.0-5.5 \\
F 6,6.0-6.5\end{array}$ \\
\hline
\end{tabular}

Analytical results of the initial 16 subsurface soil samples indicate that shallow soils (less than about $2 \mathrm{ft}$ deep) adjacent to the former building 2206 are contaminated with large concentrations (greater than several thousand micrograms per kilogram) of organochlorine pesticides (table 8). Concentrations attenuate rapidly with increasing depth, and samples collected from depths of $2 \mathrm{ft}$ or greater generally contained less than a few tens of micrograms per kilogram total pesticides. Similar to previously collected soil samples, the predominant compounds detected were chlordane, DDT, $\mathrm{DDD}$, and DDE. Most organochlorine pesticides are practically insoluble in water and have large partitioning coefficients, thus strongly partition into soil organic matter. The observed rapid attenuation with increasing depth is consistent with the visible decrease in soil organic matter below about $1 \mathrm{ft}$. Because of their strong affinity for organic matter and low water solubility, the vertical migration of organochlorine pesticides through the unsaturated zone is unlikely.

Although the vertical migration of organochlorine pesticides from contaminated soils at FLW-037 is unlikely, the lateral transport of contaminated soils by stormwater runoff has occurred. Two streambed sediment samples collected from the unnamed tributary about 500 and 2,500 ft downstream from FLW-037 (fig. 31) contained large concentrations of chlordane ( 550 to an estimated $1,900 \mu \mathrm{g} / \mathrm{kg}$ ), DDT (480 to 940 $\mu \mathrm{g} / \mathrm{kg}$ ), DDD (330 to $1,200 \mu \mathrm{g} / \mathrm{kg}$ ), and DDE (170 to $250 \mu \mathrm{g} / \mathrm{kg}$ ) (table 8). Streambed sediment sample sd 001 also contained larger than background concentrations of $\mathrm{Cd}(3 \mathrm{mg} / \mathrm{kg}), \mathrm{Cu}$ (71 and $260 \mathrm{mg} / \mathrm{kg}), \mathrm{Pb}(210$ $\mathrm{mg} / \mathrm{kg}$ ), and $\mathrm{Zn}(750 \mathrm{mg} / \mathrm{kg})$ (table 7). Optical mineralogy of the heavy mineral concentrate from this sample revealed the presence of anthropogenic particulates such as green leaded glass, brass, and silicon carbide (industrial abrasive), which is thought to originate from the many maintenance shops and repair depots adjacent to FLW-037. Streambed sediment sample sd 002 also contained larger than background $\mathrm{Pb}(96 \mathrm{mg} / \mathrm{kg})$ and $\mathrm{Zn}(360 \mathrm{mg} / \mathrm{kg})$. To determine if substantial migration of contaminated soils from the site was continuing, an automatic water-quality sampler was placed at a road crossing about $600 \mathrm{ft}$ downstream from FLW-037. Five water samples (unfiltered) were collected from two small runoff events during early 1997 (table 16). Small concentrations (less than $1 \mu \mathrm{g} / \mathrm{L}$ total pesticides) of organochlorine pesticides were detected in all five samples, indicating transport of small quantities of contaminated soils from FLW-037 or streambed sediments within the tributary is occurring. Effects from FLW037 also were observed at the mouth of the unnamed tributary draining the site. An unfiltered water sample collected from the mouth of this tributary on April 4, 1995 (sw 008), contained a trace concentration of DDE (estimated at $0.001 \mu \mathrm{g} / \mathrm{L}$ ) (table 11) and was the only surface-water sample collected at the FLWMR to contain a detectable concentration of an organochlorine pesticide.

The three runoff samples collected in January 1997 also had elevated specific conductance values $(1,030$ to $1,160 \mu \mathrm{S} / \mathrm{cm})$ and elevated concentrations of $\mathrm{Na}_{\mathrm{t}}(150$ to $170 \mathrm{mg} / \mathrm{L}), \mathrm{Pb}_{\mathrm{t}}(1,900$ to $7,800 \mu \mathrm{g} / \mathrm{L}), \mathrm{Ni}_{\mathrm{t}}$ $(45$ to $220 \mu \mathrm{g} / \mathrm{L})$, and total zinc $\left(\mathrm{Zn}_{\mathrm{t}}, 150\right.$ to $\left.730 \mu \mathrm{g} / \mathrm{L}\right)$ (table 16). The elevated specific conductance values and concentrations of $\mathrm{Na}_{\mathrm{t}}$ are related to road salt that had been applied to roads and parking lots several days preceding the January 22,1997 , runoff. The source for the elevated concentrations of $\mathrm{Pb}_{\mathrm{t}}, \mathrm{Ni}_{\mathrm{t}}$, and $\mathrm{Zn}_{\mathrm{t}}$ is unknown. 
Table 16. Estimated discharge and concentration of selected physical properties, pesticides, and inorganic constituents in runoff samples from solid-waste management unit FLW-037

$[--$, no data available; $<$, less than $]$

\begin{tabular}{|c|c|c|c|c|c|c|}
\hline Physlcal property of constituent & $\begin{array}{l}\text { Date } \\
\text { Time }\end{array}$ & $\begin{array}{c}01 / 22 / 97 \\
0136\end{array}$ & $\begin{array}{c}01 / 22 / 97 \\
0146\end{array}$ & $\begin{array}{c}01 / 22 / 97 \\
0219\end{array}$ & $\begin{array}{c}03 / 09 / 97 \\
{ }^{0} 0835\end{array}$ & $\begin{array}{c}03 / 09 / 97 \\
1045\end{array}$ \\
\hline Discharge, estimated, cubic feet per second & & 0.39 & 0.22 & 0.22 & 0.29 & 0.25 \\
\hline Specific conductance, microsiemens per centimeter & & 1,030 & 1,140 & 1,160 & 96 & 81 \\
\hline Chlordane, micrograms per liter & & .02 & .10 & -- & .23 & .10 \\
\hline Dieldrin, micrograms per liter & & .07 & .05 & .04 & .04 & .03 \\
\hline DDD, micrograms per liter & & .16 & .08 & .04 & .08 & .03 \\
\hline DDE, micrograms per liter & & .08 & .09 & .04 & .05 & .02 \\
\hline DDT, micrograms per liter & & .24 & .56 & .17 & .13 & .08 \\
\hline Calcium, total, milligrams per liter & & 49 & 40 & 25 & - & - \\
\hline Magnesium, total, milligrams per liter & & 23 & 17 & 9 & -- & -- \\
\hline Sodium, total, milligrams per liter & & 150 & 170 & 160 & -- & -- \\
\hline Antimony, total, micrograms per liter & & - & 1.6 & 1.3 & $-\cdot$ & - \\
\hline Arsenic, total, micrograms per liter & & - & 3.7 & $<1$ & -- & - \\
\hline Barium, total, micrograms per liter & & 83 & 82 & 48 & - & - \\
\hline Beryllium, total, micrograms per liter & & $<5$ & $<5$ & $<5$ & -- & -- \\
\hline Boron, total, micrograms per liter & & 33 & 29 & 41 & - & - \\
\hline Cadmium, total, micrograms per liter & & 2.3 & 1.4 & .5 & - & - \\
\hline Chromium, total, micrograms per liter & & 18 & 12 & 3.5 & -. & - \\
\hline Cobalt, total, micrograms per liter & & 3.5 & 3 & $<1$ & - & - \\
\hline Copper, total, micrograms per liter & & 54 & 29 & 13 & - & - \\
\hline Lead, total, micrograms per liter & & 7,800 & 6,800 & 1,900 & -- & - \\
\hline Manganese, total, micrograms per liter & & 95 & 61 & 18 & -- & - \\
\hline Nickel, total, micrograms per liter & & 220 & 170 & 45 & -- & - \\
\hline Selenium, total, micrograms per liter & & 13 & 8.2 & 2.5 & -- & - \\
\hline Silver, total, micrograms per liter & & $<1$ & $<1$ & $<1$ & - & - \\
\hline Thallium, total, micrograms per liter & & $<1$ & $<1$ & $<1$ & - & - \\
\hline Vanadium, total, micrograms per liter & & 26 & 19 & 5.4 & - & - \\
\hline Zinc, total, micrograms per liter & & 730 & 360 & 150 & - & - \\
\hline
\end{tabular}

${ }^{a}$ Flow weighted composite of 0830 (cond $=96$ ) and 0839 (cond=81) samples.

No monitoring or supply wells are near FLW037, and no ground-water data are available for the site. The estimated altitude of regional ground water in the vicinity of FLW-037 is about $770 \mathrm{ft}$ (fig. 2) or about $330 \mathrm{ft}$ below the land surface. The base of the Roubidoux Formation in the vicinity of FLW-037 is at an altitude of about $950 \mathrm{ft}$ (Harrison and others, 1996), indicating the regional water table beneath the site is within the Gasconade Dolomite. Based on the regional water-table map, the anticipated direction of groundwater flow beneath FLW-037 is to the northeast. Because of the thick unsaturated zone at the site and proximity to the steep valley of the Big Piney River, perched water is likely to occur within the unsaturated zone and this water may be emerging along the valley slopes of the Big Piney River and not entering the regional ground-water flow system. The upper reach of the unnamed tributary draining the FLW-037 site is a losing stream and contaminated sediments possibly may be transported, by the stream, into the subsurface through fractures or conduits.

\section{Solid-Waste Management Unit FLW-056}

Solid-waste management unit FLW-056, the former FLWMR laundry and dry cleaning facility, is in the northeast part of the FLWMR, just north of building 2352 that contains the new laundry and dry cleaning operations. In 1998, FLW-056 was a relatively level grass field (less than 1 acre) on the southeast corner of the intersection of Louisiana Avenue and First Street (fig. 33). The USEPA had previously conducted a preliminary assessment of the new laundry and dry cleaning facility, but did not address the adjacent FLW-056 (PRC Environmental Management, Inc., 1992). The 


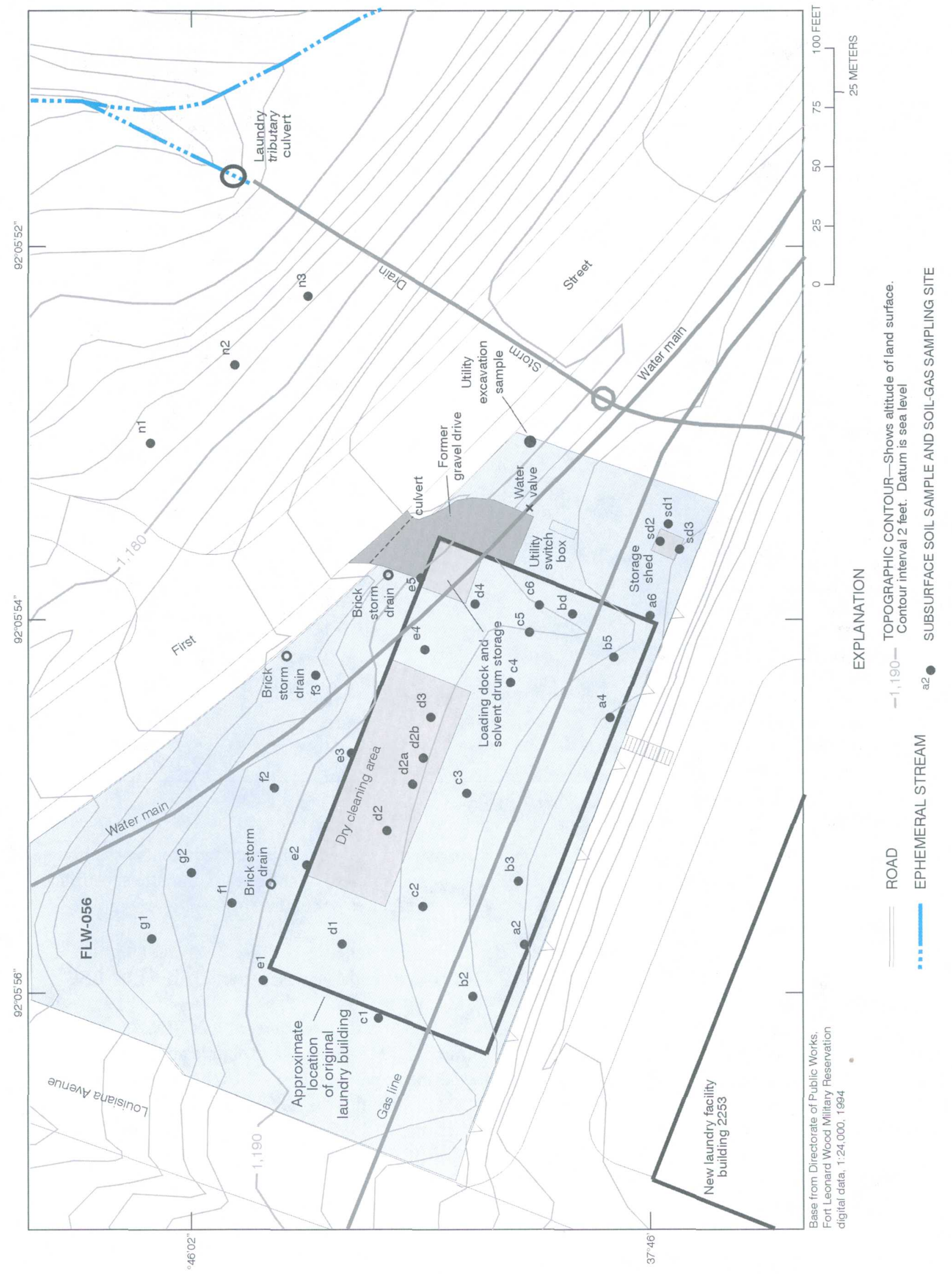

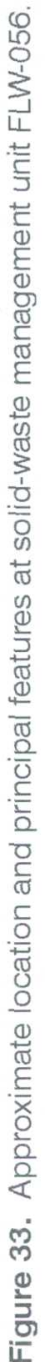


USEPA assessment concluded that, because there were no documented releases of solvents from the new dry cleaning shop and because the shop has a concrete floor and because the wastes are removed by a licensed firm, the release of solvents to the environment is unlikely. During 1997, the U.S. Army requested the USGS conduct a preliminary reconnaissance of the old laundry and dry cleaning shop site because of persistent detections of PCE at Shanghai Spring and the proximity of the old laundry facility to Shanghai Spring. The scope of this assessment included interviews with former employees, review of historical aerial photographs and construction drawings, and the collection and field analysis of VOCs (portable GC) in wastewater samples from the new dry cleaning shop and storm drains near FLW-056, and in subsurface soil and soil-gas samples from the FLW-056 site.

The old laundry and dry cleaning facility was in operation from the mid- to late 1940's to 1981 when the building was demolished and operations moved to building 2352 (Rory McCarthy, oral commun., 1997). Design drawings indicate the original building was about $96 \mathrm{ft}$ wide (north-south) and $160 \mathrm{ft}$ long and had a capacity of $60,000 \mathrm{lbs}$ of laundry per week. The building was wood framed and had a concrete floor that, according to former employees, was cracked and crumbling. Dry cleaning operations were conducted in the northern part of the building where several dry cleaning machines and a solvent storage tank were located (fig. 33). A covered loading dock was at the northeast end of the building. Interviews with former employees indicate that drums of dry cleaning solvents were stored inside a fenced section of the loading dock. There also was a 15 - by 15 - $\mathrm{ft}$ wood-floored storage shed on the east side of the old laundry building. Old equipment and bulk chemicals, including sulfuric acid and other unknown chemicals, were stored inside the shed.

During most of the time the old laundry facility was in operation, the primary dry cleaning solvent used was TCE. Former employees indicated that solvent spills frequently occurred at the facility, especially when the old dry cleaning machines "boiled over" during a heating stage where TCE was volatilized to remove impurities. The spills were absorbed using a diatomaceous earth compound or swept out the nearest door. The solvent-soaked absorbent was placed with other waste in a dumpster near the northeast corner of the building and hauled to one of the FLWMR sanitary landfills. Solvents also were reportedly dumped on the gravel driveway near the loading dock. During the 1970's, TCE was replaced by PCE as the primary dry cleaning solvent. Boil over of the dry cleaning machines continued, and PCE spills were treated in much the same manner as TCE spills; however, during the 1970's, used PCE from the dry cleaning machines was frequently dumped on the gravel drive and parking area near the loading dock. Prior to the demolition of the old laundry building during 1981, the old dry cleaning machines were moved to the new laundry facility and used until about 1983 when they were replaced with newer machines. Records of the volume of solvents used at the old laundry facility do not exist. According to the manager of the new laundry facility, the new laundry facility consumes between 300 and 400 gal of PCE each year. Because the new dry cleaning machines operate more efficiently and "boil-overs" and spills have been virtually eliminated, it is assumed that in excess of 300 to 400 gal of TCE or PCE were consumed each year at the old laundry facility.

During 1997, soil samples were collected from a utility excavation backfill near FLW-056, and water samples were collected from the laundry tributary culvert. Water samples also were collected from a coolingwater drain inside the new laundry facility (building 2352), from a 5-gal bucket used to collect overflow from the oil/water separator on one of the dry cleaning machines, and a culvert just north of FLW-056. All samples were analyzed using a portable GC. Although the soil samples were collected several days after the excavation work had been completed, small concentrations of PCE and other VOCs were detected (table 17, at the back of this report), indicating the presence of solvent contaminated soils at FLW-056.

Cooling water from the laundry building and associated boiler plant (about $0.1 \mathrm{ft}^{3} / \mathrm{s}$ ) discharges into a storm sewer outside building 2352 where it flows beneath FLW-056 and emerges at the laundry tributary culvert (fig. 33). Variable field determined concentrations of PCE $(2.1$ to $81 \mu \mathrm{g} / \mathrm{L})$ and TCE $(0.3$ to 14.6 $\mu \mathrm{g} / \mathrm{L})$ were detected in 12 water samples from the culvert (table 17). The ratios of PCE/TCE in the culvert samples ranged from about 6 to 17 (average of about 9). The largest PCE and TCE concentrations were detected during an apparent flush cycle of cooling water that occurred between 1800 and 1812 on February 5, 1997, from either building 2352 or the nearby boiler plant. Samples collected inside of building 2352 the following day indicated that, although large field determined PCE concentrations $(10,100 \mu \mathrm{g} / \mathrm{L})$ were detected in the 
oil/water separator overflow bucket, the PCE and TCE concentrations in the cooling water discharge line (3.0 and less than $0.05 \mu \mathrm{g} / \mathbb{L}$ ) were too small and the $\mathrm{PCE} / \mathrm{TCE}$ ratios too large (greater than 60 to 439 ) to be the source of the PCE and TCE concentrations detected in the laundry tributary culvert. The facility manager indicated that the oil/water separator overflow bucket would fill to capacity every few weeks and the bucket would then be emptied into the floor drain where it would flow into the storm drain that discharges through the laundry tributary culvert. The bucket had not been emptied for several weeks prior to the reconnaissance sampling and, thus, could not be the source of the increased PCE and TCE concentrations detected in the laundry tributary culvert the previous evening. The practice of emptying the oil/water separator overflow bucket into the floor drain was discontinued in March 1997; however, samples collected from the laundry tributary culvert in March and April continued to contain PCE and TCE (table 17).

Although moderately large concentrations of PCE and TCE were detected in the laundry tributary culvert, these compounds volatilize quickly and did not appear to affect surface-water resources further downstream. A reconnaissance of the laundry tributary on February 7, 1997, indicated that field determined concentrations of PCE and TCE in the laundry tributary decreased rapidly from 13.7 and $0.8 \mu \mathrm{g} / \mathrm{L}$ at the culvert to less than $0.2 \mu \mathrm{g} / \mathrm{L}$ at 800 and $1,600 \mathrm{ft}$ downstream on February 7, 1997. Discharge measurements made during the reconnaissance indicate that downstream from the culvert the laundry tributary gained flow from several sources, including an overflowing sanitary sewer manhole and a suspected water main leak. The laundry tributary discharges into Dry Creek about $2,000 \mathrm{ft}$ downstream from FLW-056 (fig. 2).

Subsurface soils at FLW-056 have been contaminated by PCE and TCE. In response to the detection of PCE and TCE in surface samples from the nearby utility excavation, a $40-\mathrm{ft}$ grid was surveyed across the FLW-056 site (fig. 33). Subsurface soil samples (2 to 3 $\mathrm{ft}$ deep) were collected from soil borings at each grid point using a tractor mounted auger drill rig. Samples also were taken from three borings located beneath the former storage shed. Samples were not collected from grid points where auger refusal was encountered at depths less than $1 \mathrm{ft}$. Soil-gas samplers were installed at each location where refusal was not encountered (fig. 33). The largest field determined concentrations of $\operatorname{PCE}(460,000 \mu \mathrm{g} / \mathrm{kg})$ and TCE $(136,000 \mu \mathrm{g} / \mathrm{kg})$ were detected beneath the loading dock and solvent storage area near the northeast corner of the former building. Large field determined concentrations of PCE (264 to $26,000 \mu \mathrm{g} / \mathrm{kg}$ ) were also detected from subsurface soil samples beneath the former laundry area (fig. 34). Additional subsurface samples were collected on a 5-ft grid in these areas and analyzed using the portable GC. To confirm the presence of PCE and TCE detected by the portable GC, four split samples were collected from boreholes and submitted for laboratory analyses of VOC using USEPA method 8260A (table 18). Because of the extreme heterogeneity in the sample matrix, considerable variability existed between the laboratory and field determined concentrations.

Soil-gas samples from FLW-056 also contained detectable concentrations of PCE (table 19, at the back of this report). Similar to the subsurface soil samples, soil-gas samples collected from areas beneath the former dry cleaning area and the loading dock and solvent drum storage area contained the largest concentrations. The largest concentrations of $\mathrm{PCE}$ [estimated at $25.2 \mathrm{ppm}$ (parts per million)] and TCE (4.9 ppm) were detected in soil-gas sampler $\mathrm{E} 5$ in the northeastern part of the site (fig. 33). A split sample from this sampler was analyzed by GC-MS at the Oregon Graduate Institute and contained concentrations of PCE (10.3 ppm) and TCE (1.4 ppm) smaller than those detected by the portable GC. A large degree of uncertainty exists in the laboratory GC-MS results because a constant flow rate of soil gas was difficult to maintain through the adsorption cartridges used for the laboratory analyses. In addition, the concentrations reported exceeded the calibration range of the GC-MS, and no air standards were available for the portable GC. Despite the uncertainty in the accuracy of the air concentrations values, the laboratory GC-MS data confirm the presence of PCE and TCE in soil-gas samples from FLW-056.

Results of the shallow subsurface assessments at FLW-056 indicate soils at the site are contaminated with large concentrations of chlorinated solvents-predominantly PCE and TCE. The detection of PCE and TCE is consistent with the use of these compounds at the facility and reports of occasional spills noted by former employees. The large PCE concentrations in the vicinity of the loading dock and solvent drum storage area are consistent with recollection of former employees, indicating waste solvents were dumped on land surface in this area. 


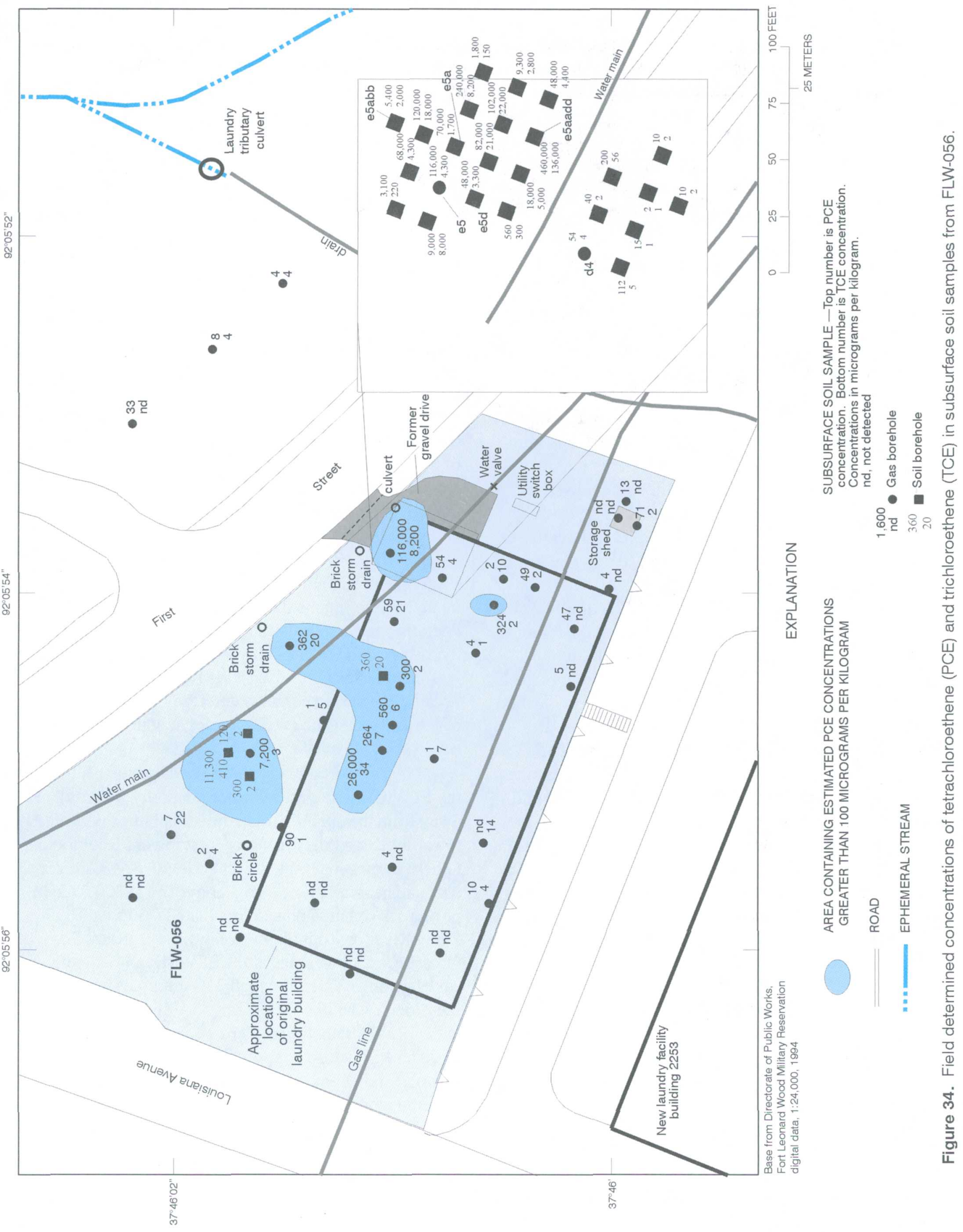


Table 18. Comparison of laboratory and field determined concentrations of tetrachloroethene (PCE) and trichloroethene (TCE) in subsurface soil samples submitted for laboratory analysis from solid-waste management unit FLW-056 [All concentrations in micrograms per kilogram; <, less than]

\begin{tabular}{|c|c|c|c|c|}
\hline \multirow[b]{2}{*}{$\begin{array}{l}\text { Sample } \\
\text { (flg. 34) }\end{array}$} & \multicolumn{2}{|c|}{ Laboratory } & \multicolumn{2}{|c|}{$\begin{array}{l}\text { Field determined } \\
\text { (portable gas chromatograph) }\end{array}$} \\
\hline & $\begin{array}{l}\text { Tetrachloroethene } \\
\text { (PCE) }\end{array}$ & $\begin{array}{l}\text { Trichloroethene } \\
\text { (TCE) }\end{array}$ & $\begin{array}{l}\text { Tetrachloroethene } \\
\text { (PCE) }\end{array}$ & $\begin{array}{l}\text { Trichloroethene } \\
\text { (TCE) }\end{array}$ \\
\hline E5ax & 23,000 & $<620$ & 70,000 & 1,700 \\
\hline E5dx & 200,000 & $<6,200$ & 48,000 & 3,300 \\
\hline E5aaddx & 120,000 & 4,400 & 460,000 & 136,000 \\
\hline E5abb & 340 & 110 & 5,400 & 2,000 \\
\hline
\end{tabular}

The estimated altitude of regional ground water in the vicinity of FLW-056 is about $790 \mathrm{ft}$ (fig. 2) or 300 $\mathrm{ft}$ below the land surface. The base of the Roubidoux Formation in the vicinity of FLW-056 is at an altitude of about $950 \mathrm{ft}$ (Harrison and others, 1996), indicating the regional water table beneath the site is within the Gasconade Dolomite. Based on the regional watertable map, the anticipated direction of ground-water flow beneath FLW-056 is to the northeast. Because of the thick unsaturated zone at the site, perched water is likely to occur beneath FLW-056, and this water may migrate in directions contrary to the direction of regional ground-water flow until reaching the regional water table. The site lies within the contributing recharge area to Shanghai Spring, and near Dry Creek which is hydrologically connected to the spring orifice (Imes and others, 1996), and shallow ground water beneath the site probably discharges at Shanghai Spring about $4.5 \mathrm{mi}$ to the north (fig. 5). Because the persistent detections of PCE in Shanghai Spring and large concentrations of PCE in soils at FLW-056, the site probably is contributing to the PCE contamination detected at Shanghai Spring. Further subsurface characterization is needed to determine the vertical extent of soil contamination and ground-water quality beneath the site.

\section{SUMMARY AND CONCLUSIONS}

Geohydrologic and water-quality assessments were conducted at 12 solid-waste management units (SWMU) at the Fort Leonard Wood Military Reservation (FLWMR) by the U.S. Geological Survey in cooperation with the Fort Leonard Wood (FLW), Directorate of Public Works, Environmental Division. The assessments included a review of historical aerial photographs, interviews with former employees, and the collection of samples from soils and streambed sediments, streams, seeps and springs, and existing monitoring wells and nearby domestic or public-supply wells. Additional monitoring wells and temporary monitoring wells were installed at two sites. Samples of building materials and soil-gas samples also were collected at several sites. These assessments were conducted under guidelines of the U.S. Department of Defense, Installation Restoration Program, which requires the U.S. Department of Defense facilities to assess the extent and control the migration of environmental contaminants that may have resulted from past operations or disposal practices. An assessment of the hydrology and water quality of Shanghai Spring also was included as part of the SWMU assessments because the spring contains detectable concentrations of tetrachloroethene (PCE), a known contaminant at several SWMUs.

A north-trending ground-water divide occurs at the FLWMR with ground water generally flowing away from the uplands along the axis of this divide east toward the Big Piney River or west toward Roubidoux Creek. Depths to ground water at the FLWMR are variable and generally range from about 130 to $300 \mathrm{ft}$ (feet) or more in upland areas to less than $25 \mathrm{ft}$ in the Big Piney River or Roubidoux Creek valleys. Karst features are well developed at the FLWMR and numerous caves, springs, and more than 220 sinkholes have been identified at the FLWMR. Ground-water flow patterns at the FLWMR are the result of a complex combination of diffuse flow through porous residual material and bedrock and conduit flow through solution-enlarged opening along bedding planes and hydraulically active fractures.

Dye-trace tests indicate that a substantial part of the north-central part of the FLWMR, including 3 of the 12 SWMUs investigated (fire training area FLW028 , the old pesticide building FLW-037, and the old 
laundry and dry cleaning shop FLW-056) lie within the Shanghai Spring recharge basin. Solid-waste management units FLW-003, FLW-004, and FLW-005 (sanitary landfills) lie within the Shanghai Spring or Sandstone Spring recharge basins. The water quality of Shanghai Spring has been affected by effluent from the FLWMR wastewater treatment plant and other unidentified sources. Water samples collected from Shanghai Spring between 1995 and 1997 contained larger than background average concentrations of dissolved sodium [7.3 mg/L (milligrams per liter)], dissolved chloride $(11.6 \mathrm{mg} / \mathrm{L})$, dissolved fluoride $(0.2 \mathrm{mg} / \mathrm{L})$, total nitrite plus nitrate as nitrogen $(1.6 \mathrm{mg} / \mathrm{L})$, total phosphorus $(0.13 \mathrm{mg} / \mathrm{L})$, dissolved boron $(31 \mathrm{mg} / \mathrm{L})$, trace concentrations of the pesticides prometon and simazine [0.008 and $0.006 \mu \mathrm{g} / \mathrm{L}$ (micrograms per liter)], and the volatile organic compound (VOC) PCE $(0.6$ to $1.8 \mu \mathrm{g} / \mathrm{L}$ ). Shanghai Spring responds rapidly to runoff with discharge increasing almost immediately after the onset of runoff. A delay between the increase in discharge and decrease in specific conductance values and concentrations of inorganic constituents indicates a substantial volume of primary phreatic conducts (estimated at about 9.3 million cubic feet) supplying water to the spring orifice. Constituent loads increased with increasing discharge, indicating that the larger dissolved-solids base-flow component of flow to the spring orifice is not replaced, but diluted by runoff. Concentrations of PCE increased with increasing discharge and peaked within 24 to 48 hours following the decrease in specific conductance. The increase in PCE concentrations following runoff indicates that infiltrating rainfall or runoff entering the unsaturated zone is mobilizing PCE and quickly transporting it to the spring orifice. The peak PCE concentrations preceeded the arrival of dye injected in a sinkhole near the distal end of the spring basin (about 6.6 miles from the spring orifice) and were comparable to the arrival time of dye dumped in Dry Creek, about 3 miles from the spring orifice, indicating the source of PCE is relatively near the spring orifice. An estimated 5 to 10 gallons of PCE are discharged from Shanghai Spring each year.

Six of the 12 SWMUs investigated were abandoned sanitary landfills (FLW-002, FLW-003, FLW004, FLW-005, FLW-059, and FLW-060). Except for FLW-060, soil and streambed sediment samples from FLW-002 generally contained background concentrations of inorganic constituents. Soil and streambed sediment samples from all sanitary landfills had small concentrations (less than a few tens of micrograms per kilogram) of organochlorine pesticides such DDT, DDD, DDE, dieldrin, and gross polychlorinated biphenyls. Landfill FLW-002 is in the uplands in the westcentral part of the FLWMR and is the only one of the landfills where permanent monitoring wells have been installed to the regional water table. The site probably is near the divide between the Shanghai Spring and Miller Spring recharge basins. Analysis of soil-gas samples from FLW-002 detected benzene, toluene, ethylbenzene, and xylenes, numerous unidentified volatile hydrocarbons, and chlorinated solvents such as PCE, trichloroethene (TCE), cis-1,2-Dichloroethene, and vinyl chloride (VC); especially in the southeastern part of the site. Although shallow perched water is present in the overburden and bedrock beneath the site, the regional water table is more than $170 \mathrm{ft}$ below the land surface. Analyses of water samples collected from monitoring wells indicate that contaminants have migrated from the landfill to the regional water table. Samples from wells monitoring perched water in the overburden and shallow bedrock contained larger than background concentrations of many inorganic constituents. Concentrations of VC $(13.6 \mu \mathrm{g} / \mathrm{L})$ exceeded the Missouri Ground Water Standard of $2 \mu \mathrm{g} / \mathrm{L}$ in an overburden wells and concentrations of PCE $(4.7 \mu \mathrm{g} / \mathrm{L})$ were slightly below the Missouri Ground Water Standard of $5 \mu \mathrm{g} / \mathrm{L}$ in a shallow bedrock well. Samples from two of the four deep bedrock monitoring wells installed at the site contained larger than background concentrations of several inorganic constituents and detectable concentrations of VOCs, including PCE, indicating landfill leachate has migrated to the regional water table beneath the site.

Sanitary landfills FLW-003 (17 acres), FLW-004 (35.5 acres), and FLW-005 (29.5 acres) are together in the uplands near the central part of the FLWMR within the Sandstone Spring and possibly Shanghai Spring recharge basins. The regional water table is more than $200 \mathrm{ft}$ below the land surface at these sites and no data on the quality of water below the regional water table is available. Only 2 of the 16 existing shallow (less than $100 \mathrm{ft}$ deep) monitoring wells contained sufficient water for sampling. These two wells were completed in the overburden at landfill FLW-003. Water samples collected from these wells did not appear to be affected by landfill leachate and generally contained background concentrations of inorganic constituents and, except for a trace concentration of PCE $(0.2 \mu \mathrm{g} / \mathrm{L})$, no detectable concentrations of VOC, semi-volatile organic compounds (SVs), or pesticides. Analyses of 
water samples collected from seeps at each site indicated larger than background concentrations of many inorganic constituents (numbers in parenthesis are maximum concentrations), such as sodium $(140 \mathrm{mg} / \mathrm{L})$, chloride $(190 \mathrm{mg} / \mathrm{L})$, bicarbonate $(918 \mathrm{mg} / \mathrm{L})$, total ammonia $(30 \mathrm{mg} / \mathrm{L})$, barium $(500 \mu \mathrm{g} / \mathrm{L})$, boron $(520$ $\mu \mathrm{g} / \mathrm{L})$, iron $(150,000 \mu \mathrm{g} / \mathrm{L})$, and strontium $(400 \mu \mathrm{g} / \mathrm{L})$. Seep samples also contained VOCs with the largest concentrations ( 520 to $1,062 \mu \mathrm{g} / \mathrm{L}$ total VOC) detected in seep samples from FLW-003. Concentrations of VC in all three seep samples from FLW-003 (14 to 131 $\mu \mathrm{g} / \mathrm{L}$ ), two seep samples from FLW-004 (2 and 3.1 $\mu \mathrm{g} / \mathrm{L}$ ), and two seep samples from FLW-005 (3.9 and $7.9 \mu \mathrm{g} / \mathrm{L}$ ) exceeded the Missouri Ground Water Standard of $2 \mu \mathrm{g} / \mathrm{L}$. The detection of VC in the seep samples and PCE in a shallow monitoring well sample suggests that chlorinated solvents, such as PCE or TCE, were disposed in these landfills. A positive dye-trace test conducted between a monitoring well at FLW-005 and Sandstone Spring indicates contaminants from these sites may have, or could affect the water quality of this spring. Water samples from Sandstone Spring contained larger than background concentrations of sodium, chloride, and total nitrite plus nitrate; however, because the spring also drains a developed part of the FLWMR, the source of these constituents could not be unequivocally attributed to landfills FLW-003, FLW004, or FLW-005.

Landfill FLW-059 (about 3.5 acres) is in the northwest part of the FLWMR within the Roubidoux Creek floodplain and FLW-060 (less than 5 acres) is in the northeast part of the FLWMR along the lower reach of a tributary of the Big Piney River. The surface of FLW-060 was littered with debris, and several surficalsoil samples from this site contained larger than background concentrations of total carbon, total organic carbon, copper, manganese, lead, molybdenum, or zinc. Ground-water data at landfills FLW-059 and FLW-060 is limited because there were no seeps or nearby springs observed at either site and no monitoring wells exist. Water-level measurements in temporary monitoring wells installed at FLW-059 indicate the water table is 11 to $17 \mathrm{ft}$ below the land surface and slopes to the west and north toward Roubidoux Creek. Water samples from two of the temporary wells installed at FLW-059 contained larger than background concentrations of several inorganic constituents and detectable VOCs, indicating that the alluvial water quality at the site has been affected to a minor extent by landfill leachate. The regional water table at FLW-060 is about $70 \mathrm{ft}$ below the land surface and probably slopes to the north or east toward the Big Piney River. A water sample collected from a small tributary immediately downstream from FLW-060 contained larger than background concentrations of several inorganic constituents; however, their source could not be attributed to FLW-060.

Three of the SWMUs investigated were sites formerly used for the open burning/open detonation of ordnance (FLW-030, FLW-032) or storage of empty small arms ammunition containers (FLW-040). No ground-water data exists for FLW-030 or FLW-032. An extensive review of historical aerial photographs resulted in the revision of the location of FLW-030, a less than 5,000-square feet former open burning/open detonation area, several hundred feet to the north. Because of the potential for buried unexploded ordnance, no soil samples were collected at FLW-030 or FLW-032. Surface-water and streambed sediment samples collected near FLW-030 and FLW-032 contained no detectable concentrations of explosive indicating no apparent migration of explosives from these sites. However, streambed sample from FLW-030 contained larger than background concentrations of copper and lead that were attributed to contamination from bullet fragments and brass shell casings. In addition to metals and explosives, leaching of the wood preservative pentachlorophenol from wooden small arms ammunitions containers stored on a uncovered concrete pad was a concern at FLW-040. None of the surfical-soil and streambed sediment samples from the site contained detectable concentrations of explosives compounds or pentachlorophenol, indicating migration of substantial quantities of contaminants from the ammunition container storage area has not occurred.

Analysis of surfical-soil and subsurface soil samples collected from the old fire training area (FLW028) indicate no substantial metal and hydrocarbon contamination of surface or subsurface soils. A sample collected for a depth of $3 \mathrm{ft}$ from one borehole near the center of the site contained estimated concentrations of benzene $[0.2 \mu \mathrm{g} / \mathrm{kg}$ (microgram per kilogram)], toluene $(1.5 \mu \mathrm{g} / \mathrm{kg})$, para-xylene $(2,000 \mu \mathrm{g} / \mathrm{kg})$, meta-xylene $(50 \mu \mathrm{g} / \mathrm{kg})$, and ethylbenzene (not quantified) determined using a portable gas chromatograph $(\mathrm{GC})$ indicating the presence of an isolated zone hydrocarbon contamination.

A series of assessments were conducted at the old pesticide storage building (FLW-037) to characterize the extent and magnitude of pesticide contamina- 
tion of the building materials (interior and exterior walls, ceiling, and floor covering), slab, subslab, and adjacent soils. Analytical results of composite samples of the building materials indicated that the building materials had none of the characteristics of a hazardous waste as defined by the U.S. Environmental Protection Agency and the building was subsequently demolished. Shallow subsurface soil samples (less than $2 \mathrm{ft}$ deep) and samples of fill immediately beneath expansion joints in the building slab contained large concentrations (numbers in parenthesis are maximum concentrations detected in micrograms per kilogram) of the organochlorine pesticides chlordane $(45,000)$, DDT $(280,000)$, DDD $(27,000), \operatorname{DDE}(24,000)$, and dieldrin $(5,100)$. The largest concentrations were in fill samples collected directly beneath the building slab near floor drains. Migration of pesticides-contaminated soils and sediments from FLW-037 has occurred, and two streambed sediment samples collected about 500 and 2,500 $\mathrm{ft}$ downstream from FLW-037 contained chlordane (550 and an estimated $1,900 \mu \mathrm{g} / \mathrm{kg}$ ), DDT (480 and $940 \mu \mathrm{g} / \mathrm{kg}$ ), DDD (330 and $1,200 \mu \mathrm{g} / \mathrm{kg}$ ), and DDE (170 and $250 \mu \mathrm{g} / \mathrm{kg}$ ), in addition to larger than background concentrations of copper (71 and 260 $\mathrm{mg} / \mathrm{kg}$ ), lead (96 and $210 \mathrm{mg} / \mathrm{kg}$ ), and zinc (360 and $750 \mu \mathrm{g} / \mathrm{kg}$ ). Samples of stormwater runoff (unfiltered) collected $500 \mathrm{ft}$ downstream from FLW-037 contained trace concentrations (less than $1 \mu \mathrm{g} / \mathrm{L}$ ) of organochlorine pesticides, indicating small quantities of contaminants are actively being transported from FLW-037 in stormwater runoff.

Solid-waste management unit FLW-056 is a small (less than 1 acre) flat grassy area in the northeast part of the cantonment area that contained the former base laundry and dry cleaning shop. The former building was demolished in the early 1980's when the laundry and dry cleaning operations were moved to a newer facility immediately south of the former facility. A preliminary reconnaissance of the site detected variable concentrations of PCE $(2.1$ to $81 \mu \mathrm{g} / \mathrm{L})$ and TCE $(0.3$ to $14.6 \mu \mathrm{g} / \mathrm{L}$ ) in water samples (determined using a portable GC) collected from a culvert immediately downstream from FLW-056. Analysis of shallow (less than 3 $\mathrm{ft}$ deep) soil samples from the site using a portable GC indicated large concentrations of PCE $(460,000 \mu \mathrm{g} / \mathrm{kg})$ and TCE $(136,000 \mu \mathrm{g} / \mathrm{kg})$. The largest concentrations were detected near the northeast corner of the former building near a loading dock where solvents were stored. Large concentrations of PCE (estimated at 25.2 parts per million) and TCE (estimated at 4.9 parts per million) also were detected in soil-gas samples collected near the northeast corner of the former building. Results of the shallow subsurface assessments at FLW056 indicate soils at the site are contaminated with large concentrations of the chlorinated solvents PCE and TCE. The large PCE concentrations in the vicinity of the loading dock and solvent drum storage area are consistent with the recollections of former employees indicating that waste solvents being dumped on land surface in this area. The site lies within the contributing recharge area to Shanghai Spring about 4.5 miles to the north. Because of the persistent detections of PCE in Shanghai Spring, and the large concentrations of PCE in soils at the site, FLW-056 probably is contributing to the PCE contamination detected at Shanghai Spring.

Because the regional water table at the site is about 300 $\mathrm{ft}$ beneath the surface, further characterization is needed to determine the vertical extent of soil contamination and ground-water quality beneath the site.

\section{REFERENCES}

Atkinson, T.C., 1977, Diffuse flow and conduit flow in limestone terrain in the Mendip Hills, Somerset (Great Britain): Journal of Hydrology, v. 35, p. 93110.

Baedecker, M.J., and Back, William, 1979, Hydrogeological processes and chemical reactions at a landfill: Ground Water, v. 17, no. 5, p. 429-437.

Borden, R.C., and Yanoshak, T.M., 1990, Ground and surface water quality impacts of North Carolina sanitary landfills: Water Resources Bulletin, v. 26, no. 2, p. 269-277.

Code of Federal Regulations, 1994 (July 1), Title 40-Protection of the environment: Office of the Federal Register, U.S. Government Printing Office, Washington, D.C., Parts 261-299, 1,031 p.

Driess, S.J., 1989, Regional scale transport in a karst aquifer, 1. Component separation of spring flow hydrographs: Water Resources Research, v. 25, no. 1, p. 117-125.

Edwards, T.K., and Glysson, D.G., 1988, Field methods for the measurement of fluvial sediment: U.S. Geological Survey Open-File Report 86-531, $118 \mathrm{p}$.

Environmental Science and Engineering, 1982, Installation assessment of the U.S. Army Training Center, Fort Leonard Wood, Missouri: Report No. 322, DRXTH-AS-IA-82322. 
Fenneman, N.M., 1938, Physiography of eastern United States: New York, McGraw Hill, 714 p.

Guy, H.P., and Norman, V.W.' 1970, Field methods for the measurement of fluvial sediments: U.S. Geological Survey Techniques of Water-Resources Investigations, book 3 , chap. $\mathrm{C} 2,59 \mathrm{p}$.

Harrison, R.W., Orndorff, R.C., and Weems, Robert, 1996, Geology of the Fort Leonard Wood Military Reservation and adjacent areas of south-eastern Missouri, with contributions on Quaternary terraces by Paul E. Anderson, Dennis Mienert, and Grant Butler: U.S. Geological Survey Open-File Report 96-60, 255 p., 10 plates.

Harvey, E.J., 1980, Ground water in the SpringfieldSalem Plateaus of southern Missouri and northern Arkansas: U.S. Geological Survey WaterResources Investigations Report 80-101, 66 p.

Hess, J.W., and White, W.B., 1988, Storm response of the karstic aquifer of south-central Kentucky: Journal of Hydrology, v. 99, p. 235-252.

Imes, J.L., and Emmett, L.F., 1994, Geohydrology of the Ozark Plateaus aquifer system in parts of Missouri, Arkansas, Oklahoma, and Kansas: U.S. Geological Survey Professional Paper 1414-D, $127 \mathrm{p}$.

Imes, J.L., Schumacher, J.G., and Kleeschulte, M.J., 1996, Geohydrologic and water-quality assessment of the Fort Leonard Wood Military Reservation, Missouri, 1994-95: U.S. Geological Survey Water-Resources Investigations Report 93-4270, $134 \mathrm{p}$.

Kleeschulte, M.J., and Imes, J.L., 1997, Regional ground-water flow directions and spring recharge areas in and near the Fort Leonard Wood Military Reservation, Missouri: U.S. Geological Survey Fact Sheet 101-97, 4 p.

Lidiak, E.G., Marvin, R.F., Thomas, H.H., Bass, M.N., 1966, Eastern area, part 4, in Geochronology of the Mid-continent Region, United States: Journal of Geophysical Research, v. 71, p. 5,427-5,438.

McCracken, M.H., 1971, Structural features of Missouri: Rolla, Missouri Division of Geology and Land Survey Report of Investigations 49, 99 p.

Meiman, Joe, 1989, Investigation of flood-pulse movement through a maturely karstified aquifer at Mammoth Cave, Kentucky: Eastern Kentucky University, M.S. thesis, 343 p.

Melton, R.W., 1976, The regional geohydrology of the Roubidoux and Gasconade Formations, Arkansas and Missouri: Fayetteville, University of Arkansas, unpublished M.S. thesis, $160 \mathrm{p}$.

Middendorf, M.A., 1984a, Geology of the Devils Elbow quadrangle, Missouri: Rolla, Missouri Division of Geology and Land Survey Open-File Map OFM-84-192d-GI, 1:24,000 scale, 1 sheet.

1984b, Geology of the Waynesville quadrangle, Missouri: Rolla, Missouri Division of Geology and Land Survey Open-File Map OFM-84192c-GI, 1:24,000 scale, 1 sheet.

1986, Geology of the Drynob, Brownfield, Drew, and Winnipeg quadrangles, Missouri: Rolla, Missouri Division of Geology and Land Survey Open-File Map OFM-84-190-GI, 1:52,500 scale, 1 sheet.

Missouri Department of Natural Resources, 1996a, Missouri private water wells, heat pump systems, pump installations, and monitoring well construction rules: Rolla, Missouri Division of Geology and Land Survey, Miscellaneous Publication 50, $96 \mathrm{p}$.

\section{6b, Rules of Department of Natural}

Resources, Chapter 7, Water quality, Title $10 \mathrm{CSR}$ 20-7.031 Water-quality standards: Clean Water Commission, Jefferson City, $100 \mathrm{p}$.

Muehlberger, W.R., Denison, R.E., and Lidiak, E.G., 1967, Basement rocks in continental interior of the United States: Bulletin of the American Association of Petroleum Geologists, v. 51, p. 2,3512,380 .

Mull, D.S., Liebermann, T.D., Smoot, J.L., and Woosley, L.H., Jr., 1988, Application of dye-tracing techniques for determining solute-transport characteristics of ground water in karst terrains: U.S. Environmental Protection Agency EPA 904/6-88$001,103 \mathrm{p}$.

Parkhurst, D.L., 1995, User's guide to PHREEQC-A computer program for speciation, reaction-path, advective-transport, and inverse geochemical calculations: U.S. Geological Survey WaterResources Investigations Report 95-4227, 143 p.

PRC Environmental Management Inc., 1992, Final RCRA facility assessment report: Fort Leonard Wood, Fort Leonard Wood, Missouri: U.S. Environmental Protection Agency Office of Waste Programs Enforcement Contract No. 68-W9-0006.

Ryan, M., and Meiman, M., 1996, An examination of short-term variation in water quality at a karst 
spring in Kentucky: Ground Water, v. 24, no. 1, p. 23-30.

Schumacher, J.G., and Hockanson, E.A., 1996, Hydrogeology and water quality at the St. Francois County Landfill and vicinity, southeastern Missouri, 1990-94: U.S. Geological Survey WaterResources Investigations Report 96-4022, 138 p.

Schumacher, J.G., Sutley, S.J., and Cathcart, J.D., 1993, Geochemical data for the Weldon Spring training area and vicinity property, St. Charles County, Missouri-1990-92: U.S. Geological Survey Open-File Report 93-153, 84 p.

Shelton, L.R., 1994, Field guide for the collection and processing of stream-water samples for the National Water-Quality Assessment Program: U.S. Geological Survey Open-File Report 94-455, $42 \mathrm{p}$.

Sumner, H.S., and Easson, Greg, 1986, Geology of the Bloodland, Big Piney, Roby, and Slabtown Springs quadrangles, Missouri: Rolla, Missouri Division of Geology and Land Survey Open-File Map OFM-84-189-GI, 1:24,000 scale, 1 sheet.

Thompson, T.L., 1991, Paleozoic succession in Missouri, Part 2, Ordovician System: Missouri Department of Natural Resources, Division of Geology and Land Survey, Report of Investigations $71,282 \mathrm{p}$.

Tidball, R.R., 1984, Geochemical survey of Missouri, Geography and soil geochemistry and classification by factor analysis of Missouri agricultural soils: U.S. Geological Survey Professional Paper 954-H, I, 119 p.

Uhlman, Kristine, 1989, Hydrogeology comes to the surface: Civil Engineering, v. 59, no. 4, p. 60-62.

U.S. Army Environmental Hygiene Agency, 1988a, Interim final report, Hazardous waste consultation
No. 37-26-1646-88, Evaluation of solid waste management units, Fort Leonard Wood, Missouri, 1-4 June 1987 and 27 June-1 July 1988: Aberdeen Proving Ground, Maryland.

$$
\text { 1988b, Geohydrologic study no. 38-26-0919- }
$$

88 , Investigation of closed landfills, Fort Leonard Wood, Missouri, 19 October-6 November 1987 and 14-18 March 1988: Aberdeen Proving Ground, Maryland. 1990, Geohydrologic study no. 38-26-K86591, RCRA facility assessment - sampling visit, Fort Leonard Wood, Missouri, 13-24 August and 15-28 September 1990: Aberdeen Proving Ground, Maryland.

U.S. Environmental Protection Agency, 1984, Test methods for evaluating solid-waste, physical/chemical methods, SW-846: Washington, D.C., Office of Solid Waste and Emergency Response, Method 8270B, 3rd ed., p. 8770B-18270-B-46.

Vineyard, J.D., and Feder, G.L., 1974, Springs of Missouri, with sections on fauna and flora by W.L. Pflieger and R.G. Lipscomb (reprinted 1982): Rolla, Missouri Division of Geology and Land Survey, Water Resources Report 29, 267 p.

Ward, J.R., and Hair, C.A., 1990, Methods for the collection and processing of surface-water and bedmaterial samples for physical and chemical analyses: U.S. Geological Survey Open-File Report 90$140,71 \mathrm{p}$.

Wood, W.W., 1976, Guidelines for the collection and field analysis of ground-water samples for selected unstable constituents: U.S. Geological Survey Techniques of Water-Resources Investigations, book 1, chap. D-1, 25 p. 

TABLES 



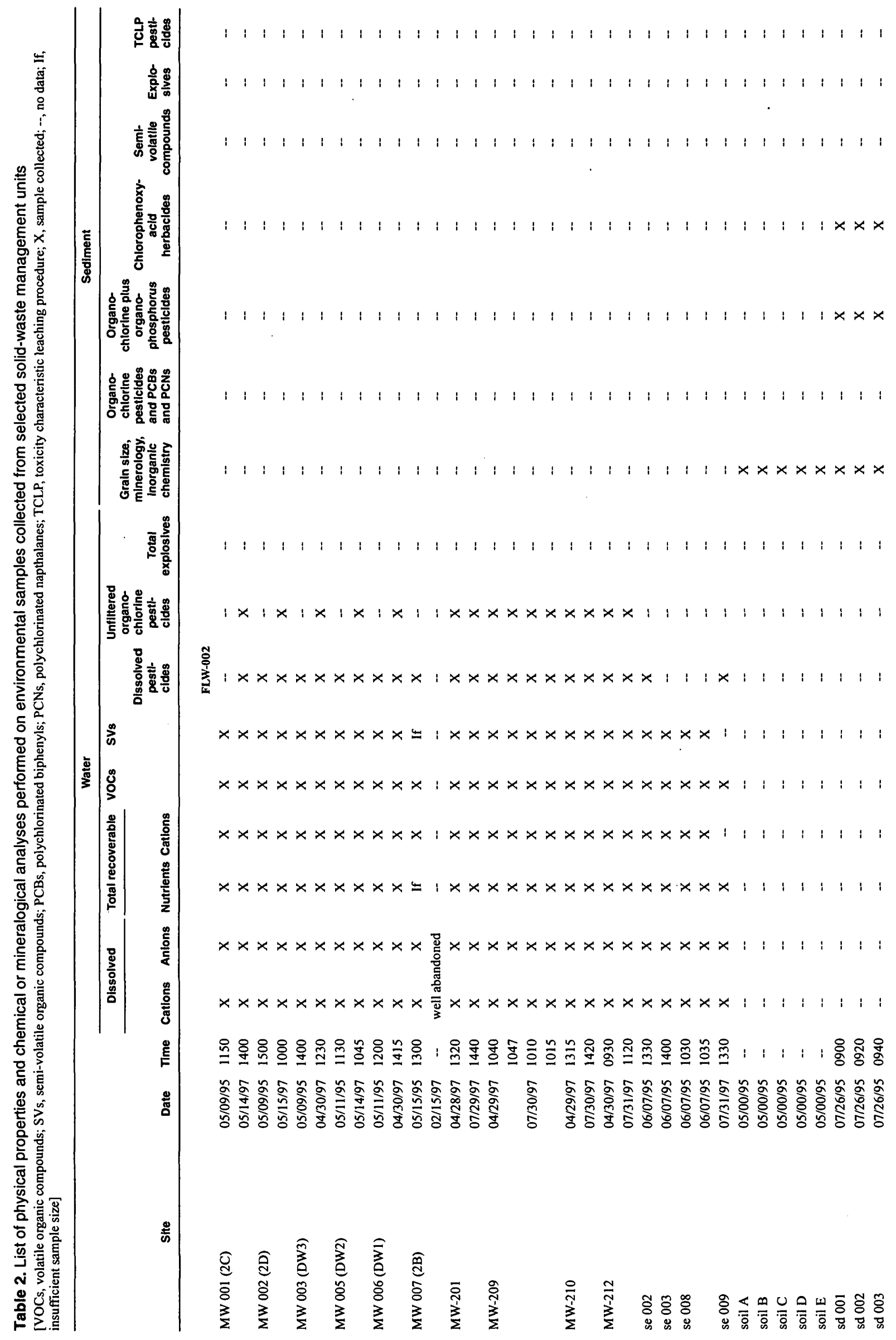




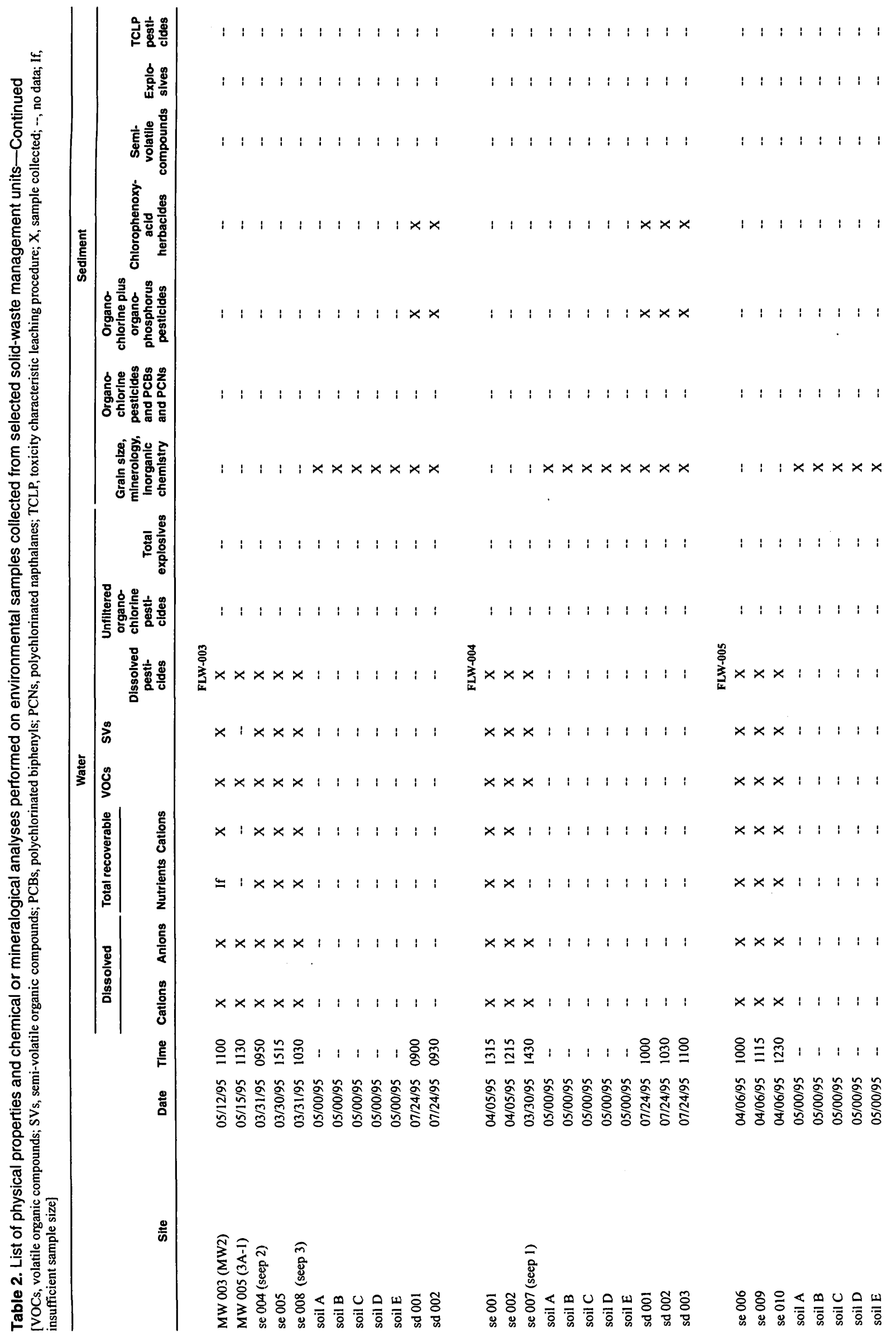




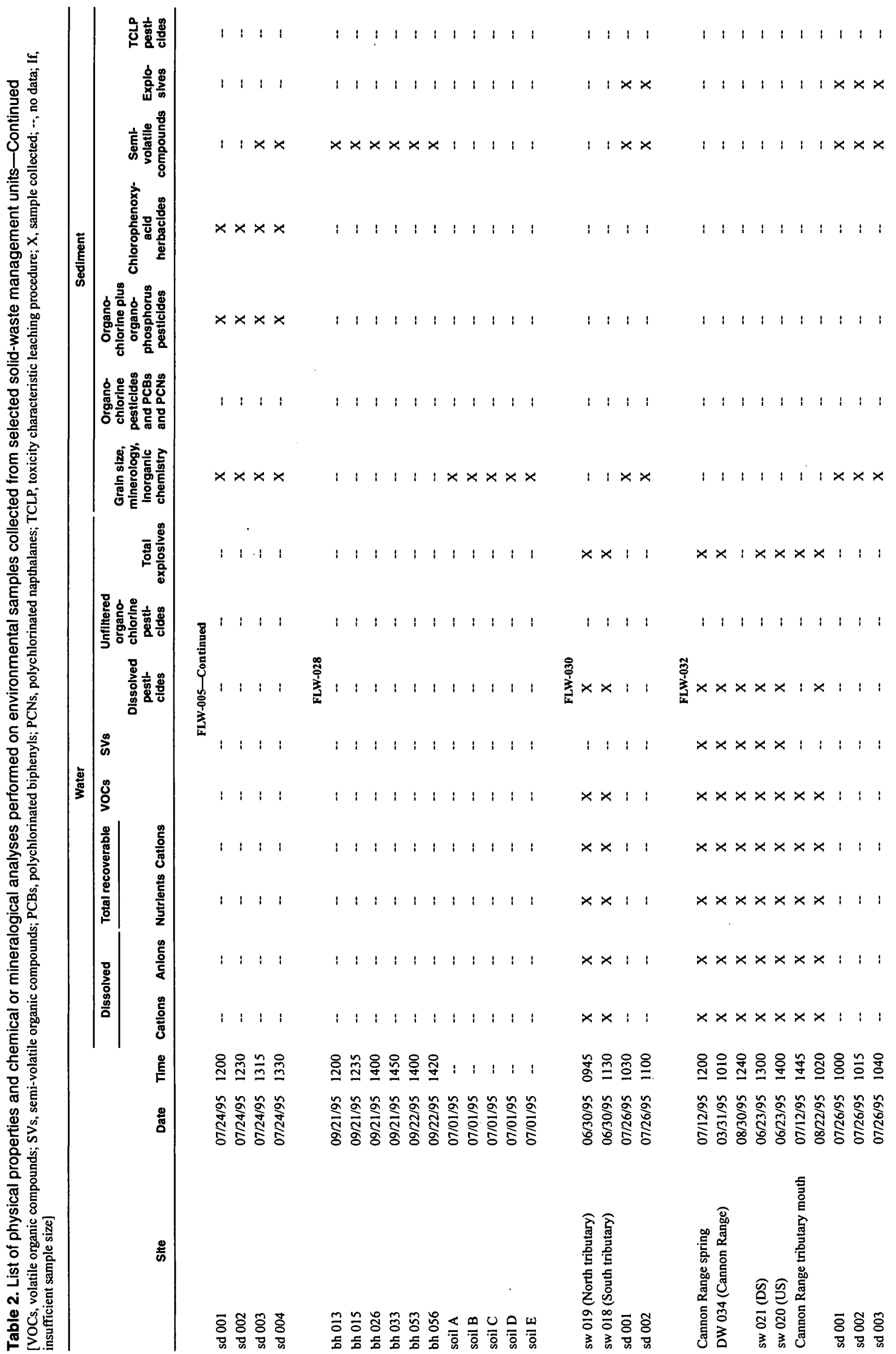

Table 291 


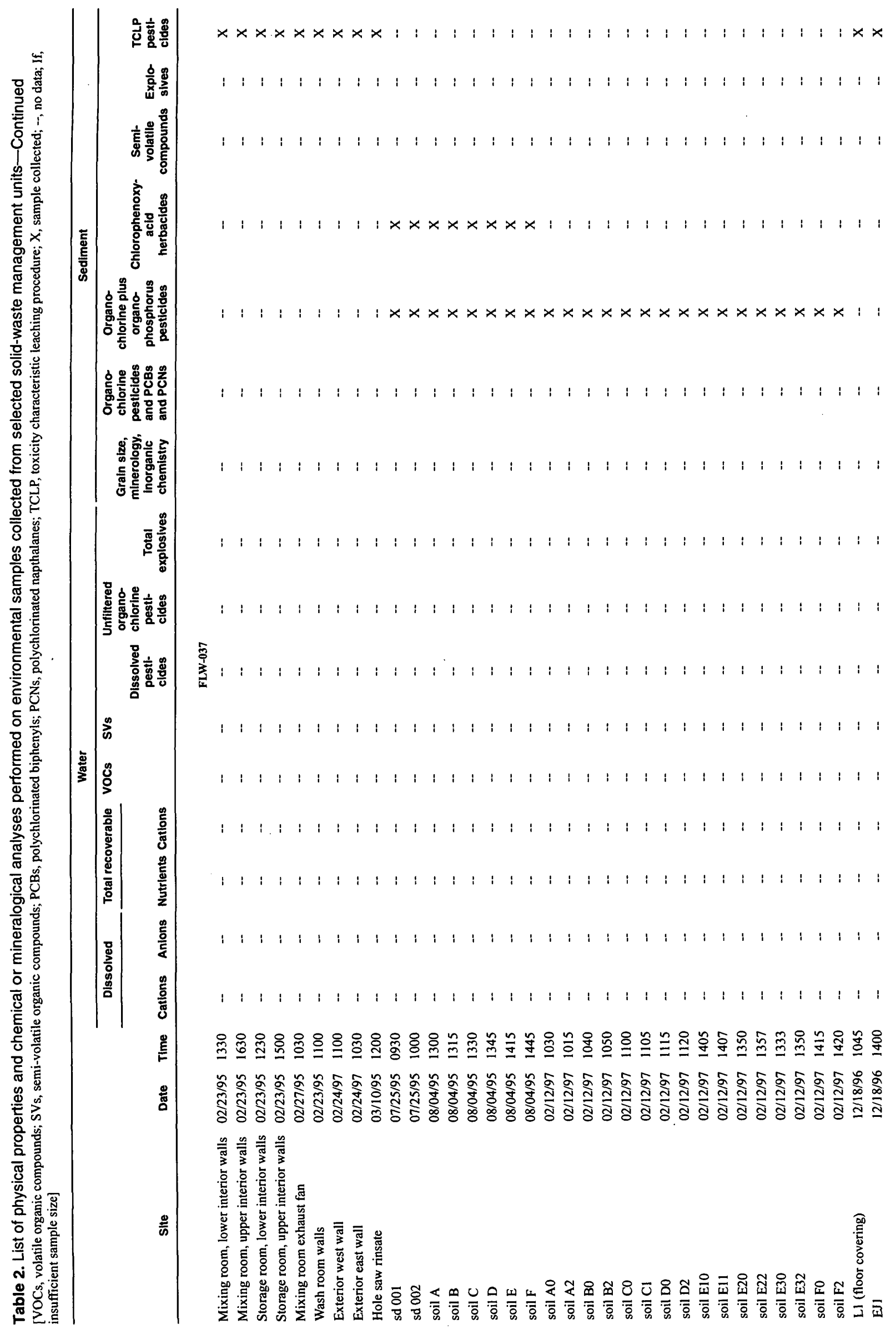




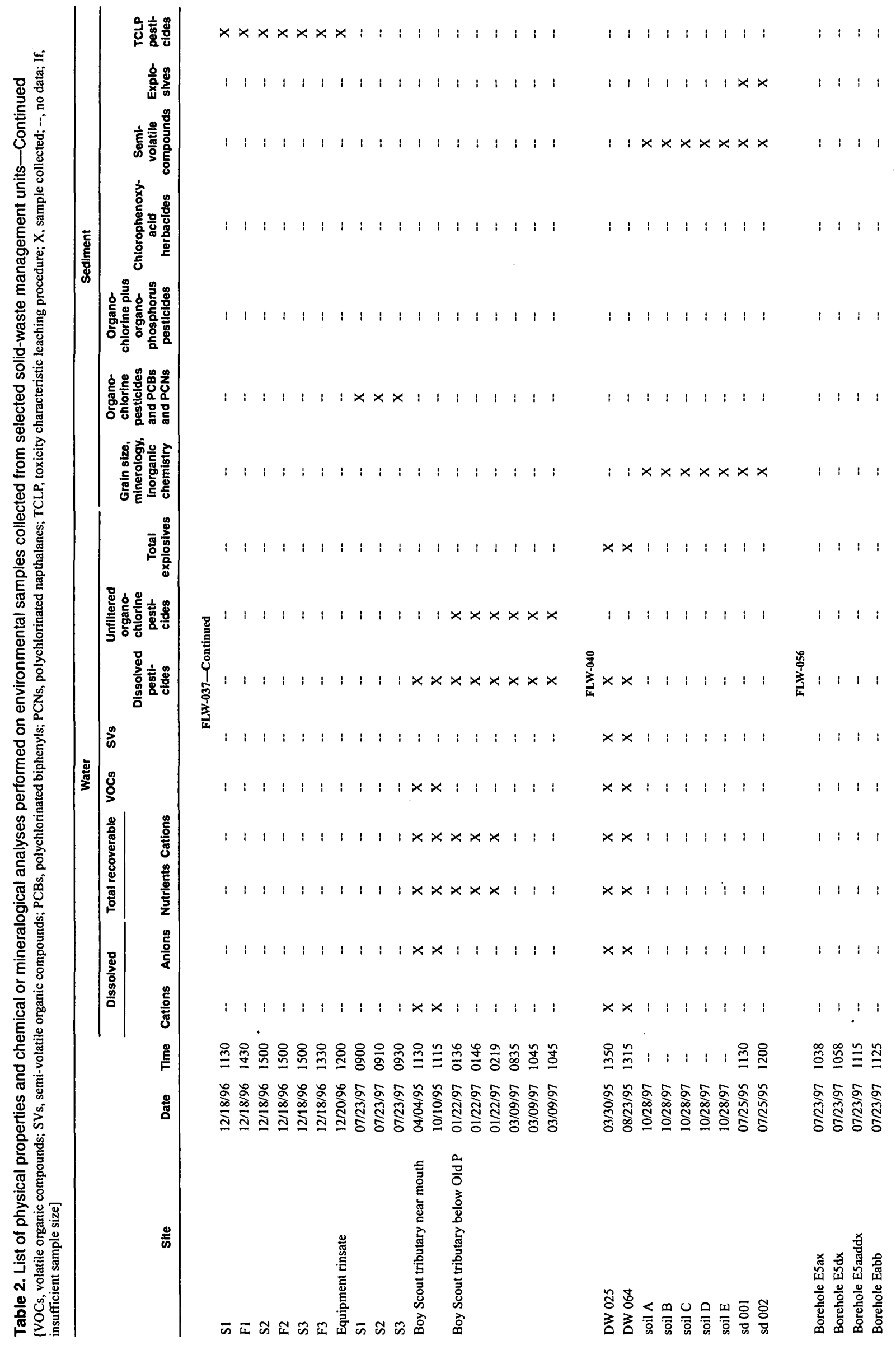




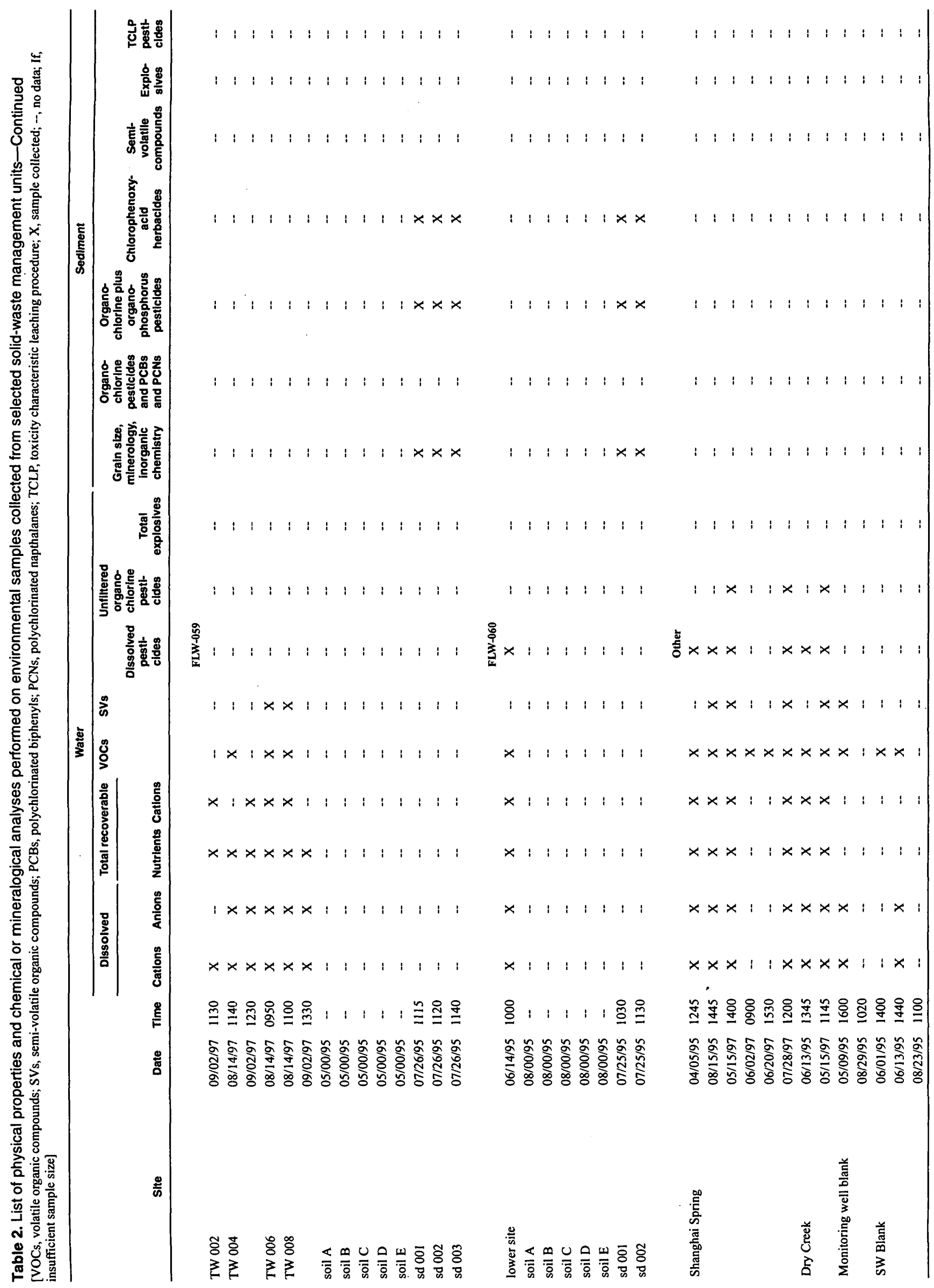

94 Geohydrology and Water Quality at the Fort Leonard Wood Military Reservation, Missouri, 1995-98 


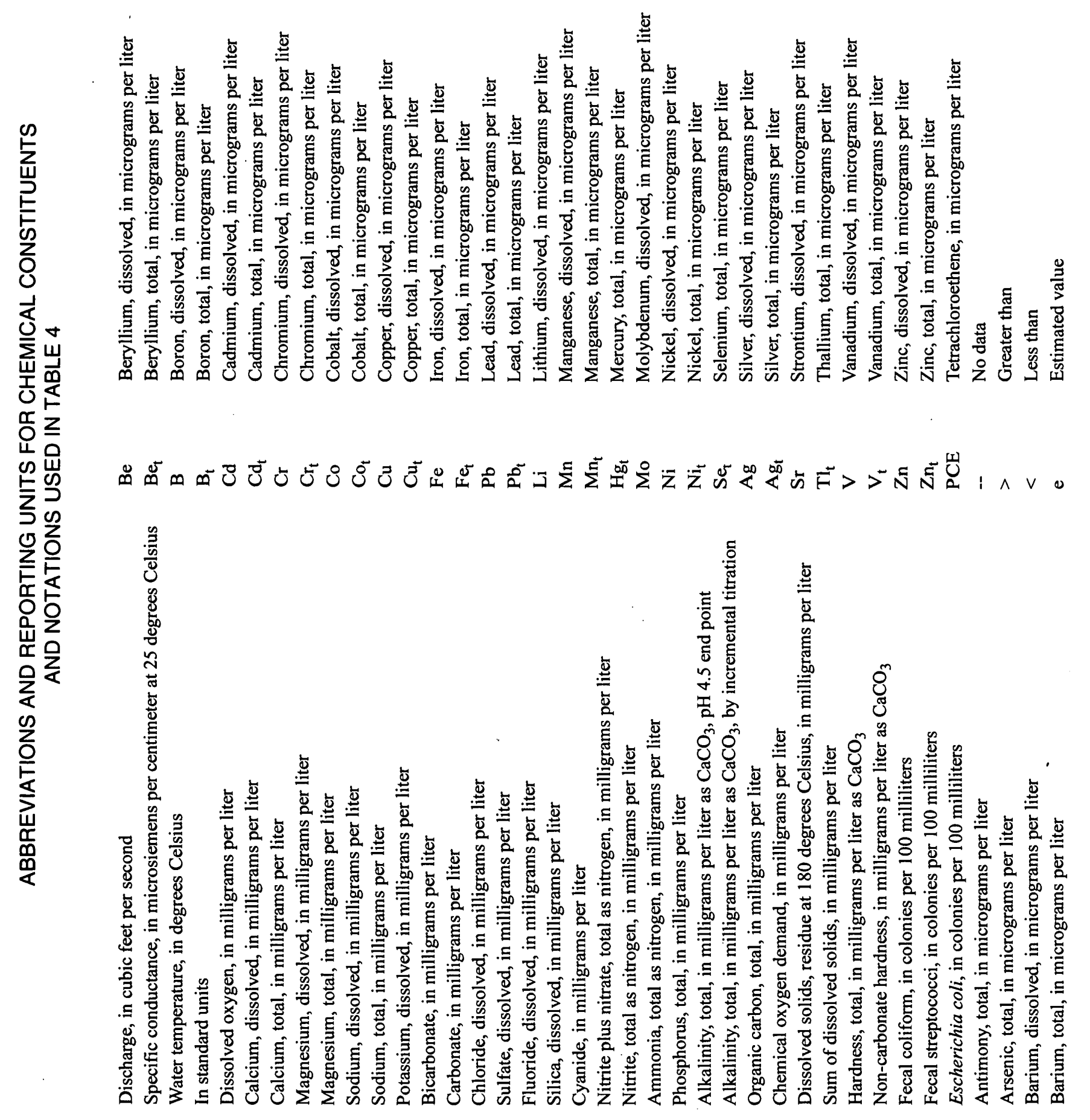

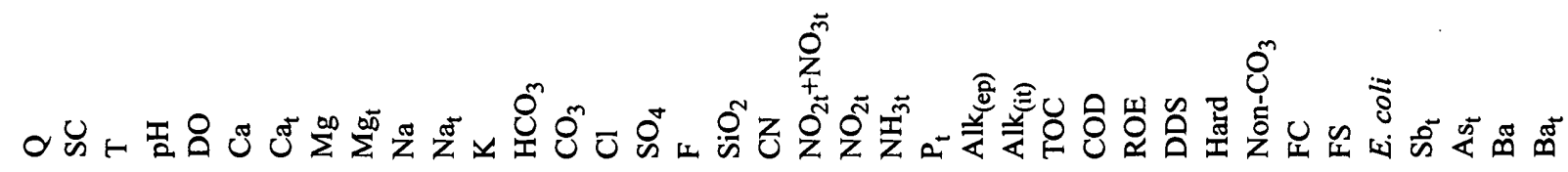




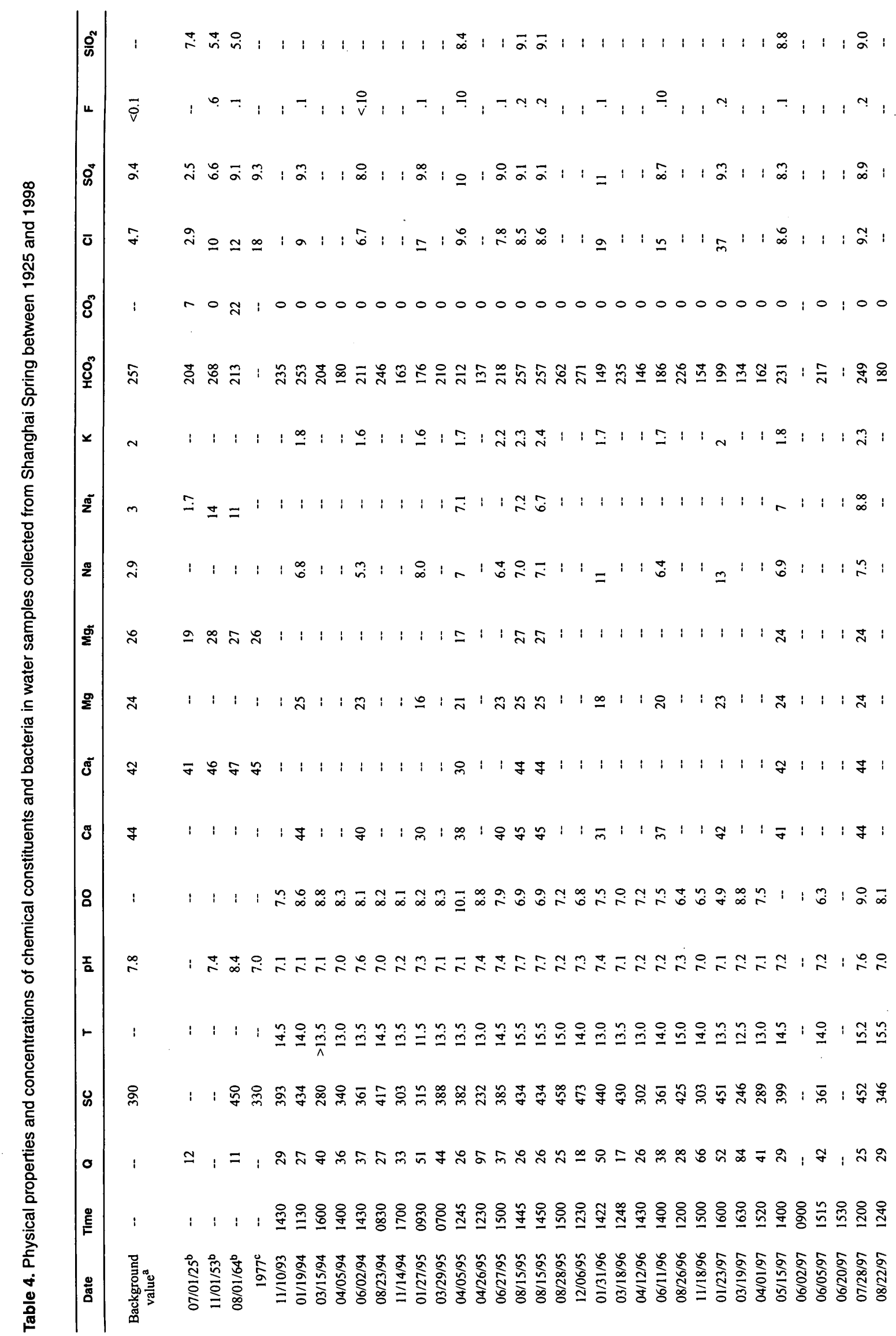




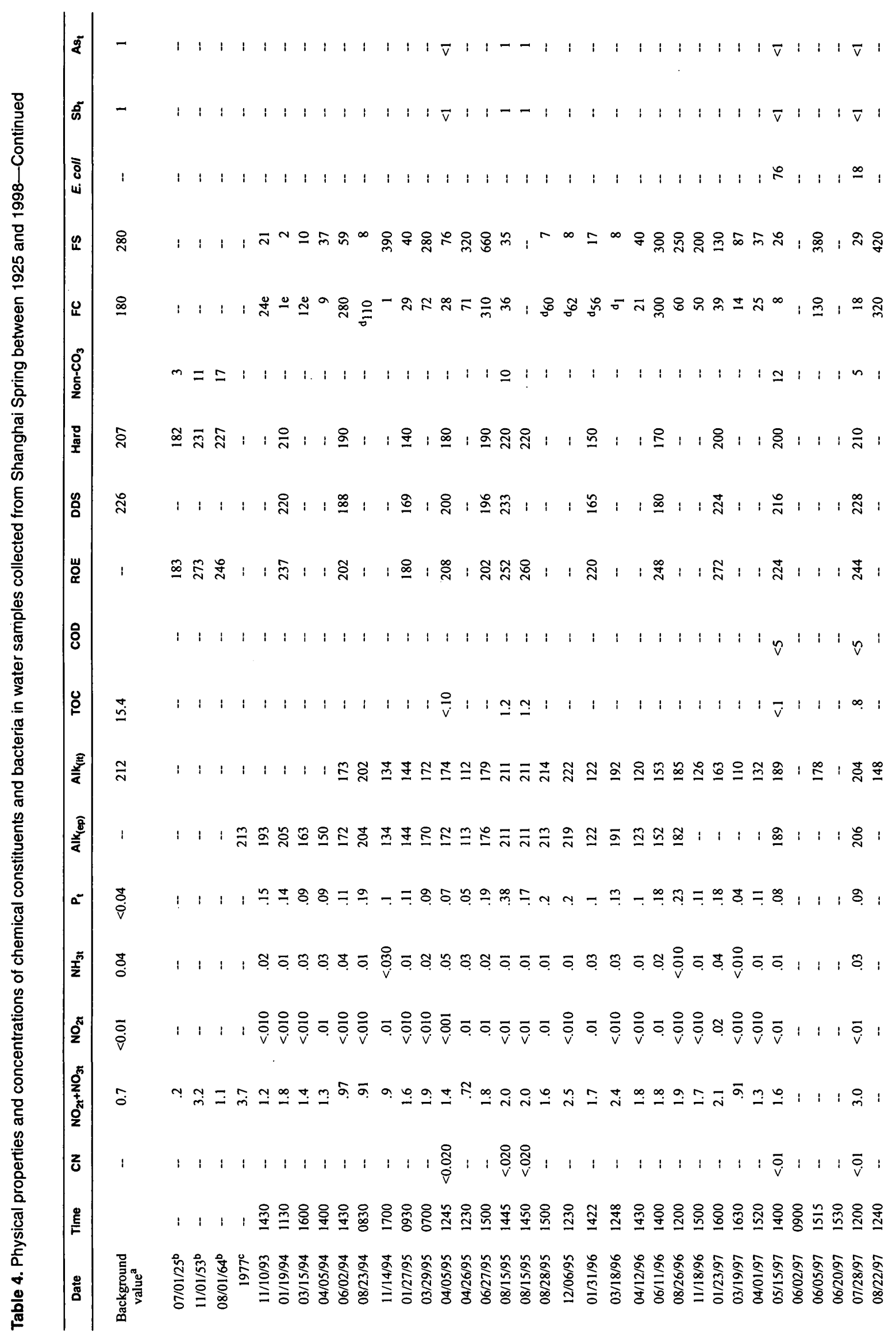




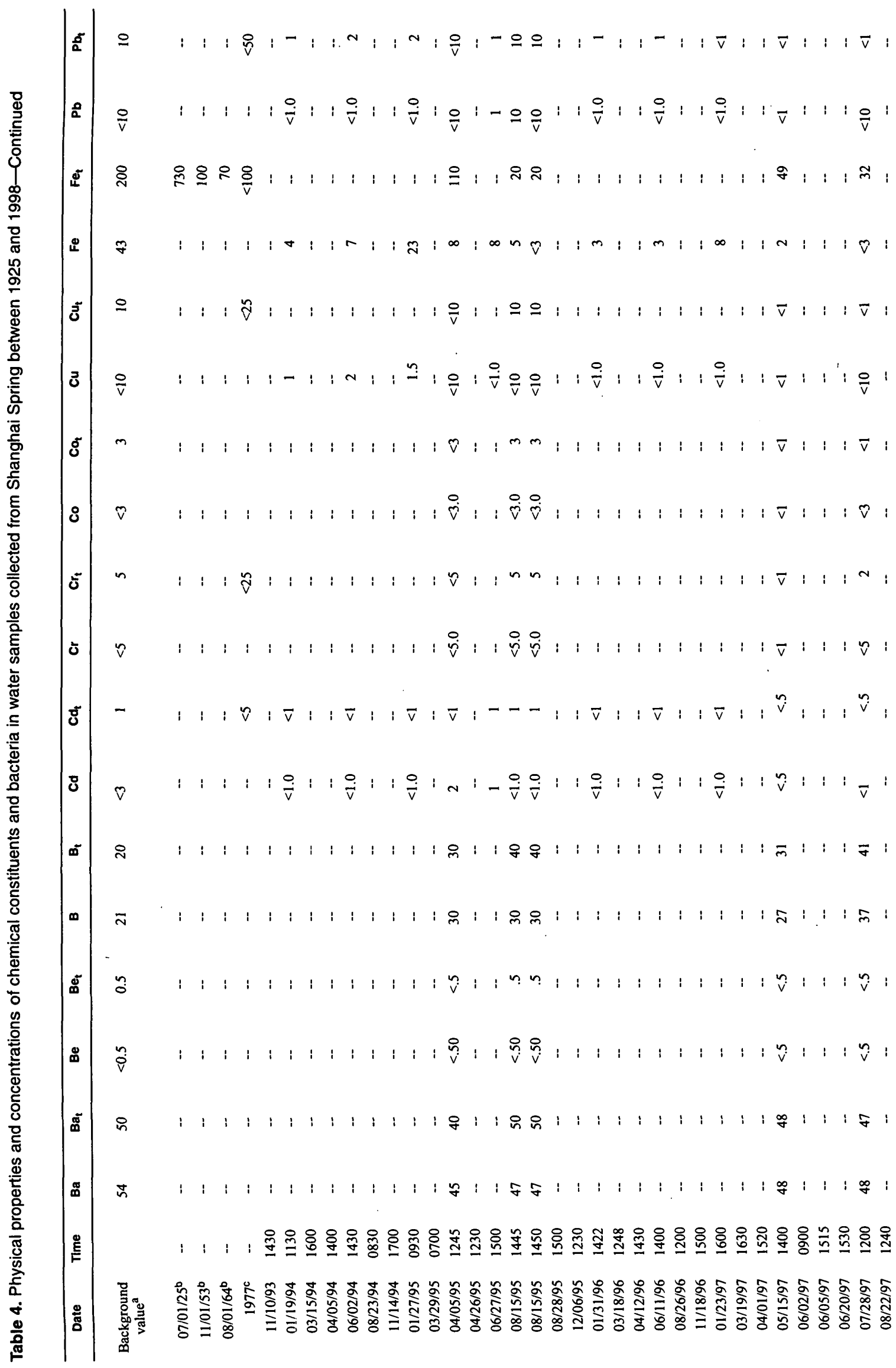



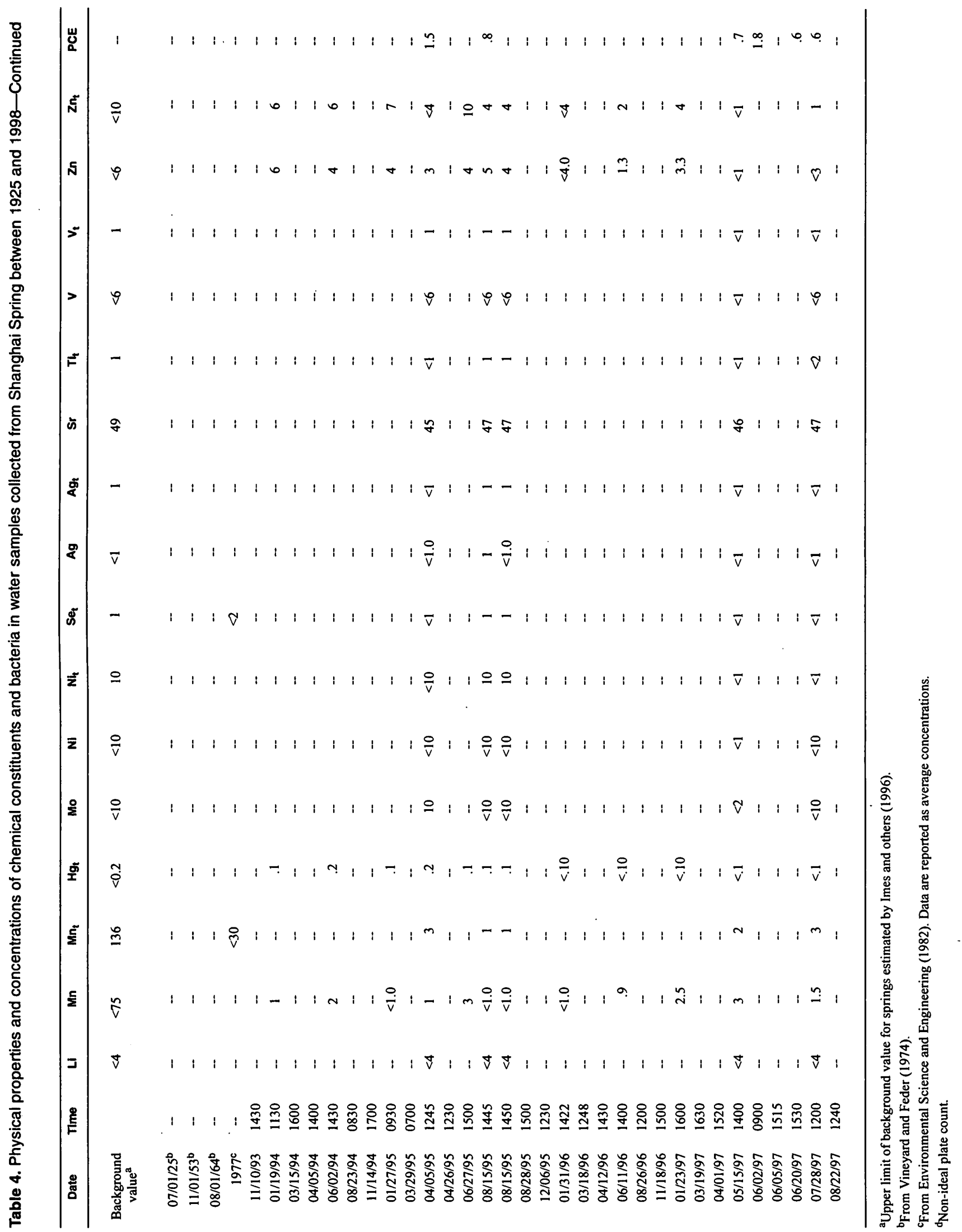
Table 5. Selected physical properties and estimated concentrations of tetrachloroethene (PCE) in water samples collected from Shanghai Spring during 1997

[--, no data available]

\begin{tabular}{|c|c|c|c|c|c|}
\hline \multirow[b]{2}{*}{ Date } & \multirow[b]{2}{*}{ Time } & \multirow[b]{2}{*}{$\begin{array}{l}\text { Discharge, } \\
\text { in cubic feet } \\
\text { per second }\end{array}$} & \multirow[b]{2}{*}{$\begin{array}{l}\text { Specific conductance, } \\
\text { in microsiemens } \\
\text { per centimeter at } 25 \\
\text { degrees Celsius }\end{array}$} & \multicolumn{2}{|c|}{ PCE concentration, in micrograms per liter } \\
\hline & & & & $\begin{array}{c}\text { Field value } \\
\text { determined using } \\
\text { portable gas } \\
\text { chromotograph }\end{array}$ & $\begin{array}{c}\text { Laboratory value } \\
\text { determined by gas } \\
\text { chromotography-mass } \\
\text { spectrometry }\end{array}$ \\
\hline $01 / 07 / 97$ & -- & -- & -- & 0.6 & - \\
\hline $01 / 21 / 97$ & -- & 0.5 & -- & .5 & -- \\
\hline $01 / 27 / 97$ & -- & -- & -- & 1.1 & -- \\
\hline $01 / 28 / 97$ & .. & -- & $\ldots$ & .8 & - \\
\hline $02 / 01 / 97$ & 1800 &.- & -- & 1.1 & -- \\
\hline $02 / 03 / 97$ & -- & .- & -- & 1.3 & -- \\
\hline $02 / 07 / 97$ & -- & -- & -- & 1.2 & -- \\
\hline $02 / 12 / 97$ & 1145 & -- & -- & 1.1 & -- \\
\hline $02 / 18 / 97$ & 1315 & -- & .. & 1.1 & -- \\
\hline $02 / 24 / 97$ & 1330 & -- & -. & 3.7 & -. \\
\hline $02 / 24 / 97$ & 1330 & -- & -. & 2.4 & -- \\
\hline $03 / 04 / 97$ & 1255 & -- & -- & 1.6 & -- \\
\hline $03 / 11 / 97$ & 1250 & - & -. & .3 & -- \\
\hline $03 / 18 / 97$ & 1424 & -- & .- & 1.4 & -- \\
\hline $03 / 19 / 97$ & 1350 & -- & -- & 1.0 & -. \\
\hline 04/01/97 & 1250 & -- & 290 & 1.0 & -- \\
\hline 04/01/97 & 1317 & -- & 292 & 1.1 & -- \\
\hline $04 / 02 / 97$ & 1515 & -- & 300 & 1.1 & -- \\
\hline $04 / 08 / 97$ & 1230 & -- & 333 & 1.0 & -- \\
\hline 04/09/97 & 1615 & -- & 331 & 1.1 & -- \\
\hline 05/01/97 & 1730 & -. & 381 & .9 & -- \\
\hline $05 / 15 / 97$ & 1400 & - & .- & .7 & 0.7 \\
\hline $05 / 20 / 97$ & 1630 & - & 412 & 1.4 & -- \\
\hline $05 / 26 / 97$ & 1715 & - & 428 & .6 & -- \\
\hline $05 / 27 / 97$ & 0250 & - & 428 & .6 & -. \\
\hline $05 / 27 / 97$ & 1400 & - & 426 & .5 & .. \\
\hline $05 / 28 / 97$ & 1200 & -- & 426 & .6 & - \\
\hline 05/30/97 & 1110 & -- & 400 & .6 & -- \\
\hline 05/30/97 & 1530 & -- & 400 & .6 & -. \\
\hline $05 / 30 / 97$ & 2000 & -- & 398 & .5 & -- \\
\hline 05/31/97 & 0830 & - & 404 & 1.0 & -- \\
\hline 05/31/97 & 1945 & - & 410 & 1.8 & -- \\
\hline $06 / 01 / 97$ & 1100 & - & 392 & 2.5 & -- \\
\hline 06/01/97 & 2040 & -. & 396 & 2.1 & -- \\
\hline $06 / 02 / 97$ & 0930 & .. & 357 & 2.3 & 1.8 \\
\hline $06 / 02 / 97$ & 1100 & - & 352 & 1.9 & - \\
\hline $06 / 03 / 97$ & 1830 & _. & 350 & 2.2 & -- \\
\hline $06 / 05 / 97$ & 1630 & - & 352 & 1.7 & -- \\
\hline $06 / 06 / 97$ & 1215 & - & 356 & 1.2 & -- \\
\hline 06/09/97 & 1330 & - & 375 & .8 & -- \\
\hline $06 / 12 / 97$ & 1335 & - & 389 & .8 & - \\
\hline $06 / 14 / 97$ & 1930 & - & 400 & .8 & -- \\
\hline $06 / 16 / 97$ & 1030 & -- & 335 & .8 & -- \\
\hline $06 / 16 / 97$ & 1400 & -- & 337 & .96 & -- \\
\hline $06 / 17 / 97$ & 0900 & -- & 336 & 1.7 & -- \\
\hline $06 / 18 / 97$ & 1030 & - & 315 & 1.2 & -- \\
\hline $06 / 18 / 97$ & 1500 & -. & 315 & 1.0 & -- \\
\hline $06 / 19 / 97$ & 1130 & -. & 304 & .5 & -- \\
\hline $06 / 20 / 97$ & 1030 & -- & 295 & .46 & -- \\
\hline $06 / 20 / 97$ & 1530 & -. & 288 & .49 & .6 \\
\hline $06 / 21 / 97$ & 1100 & -- & 290 & .86 & -- \\
\hline $06 / 22 / 97$ & 1100 & -- & 298 & .88 & -. \\
\hline $06 / 23 / 97$ & 0900 & -. & 304 & .74 & -- \\
\hline $06 / 23 / 97$ & 1445 & -- & -. & .66 & -- \\
\hline $06 / 24 / 97$ & 1510 & -- & -- & .77 & -- \\
\hline
\end{tabular}




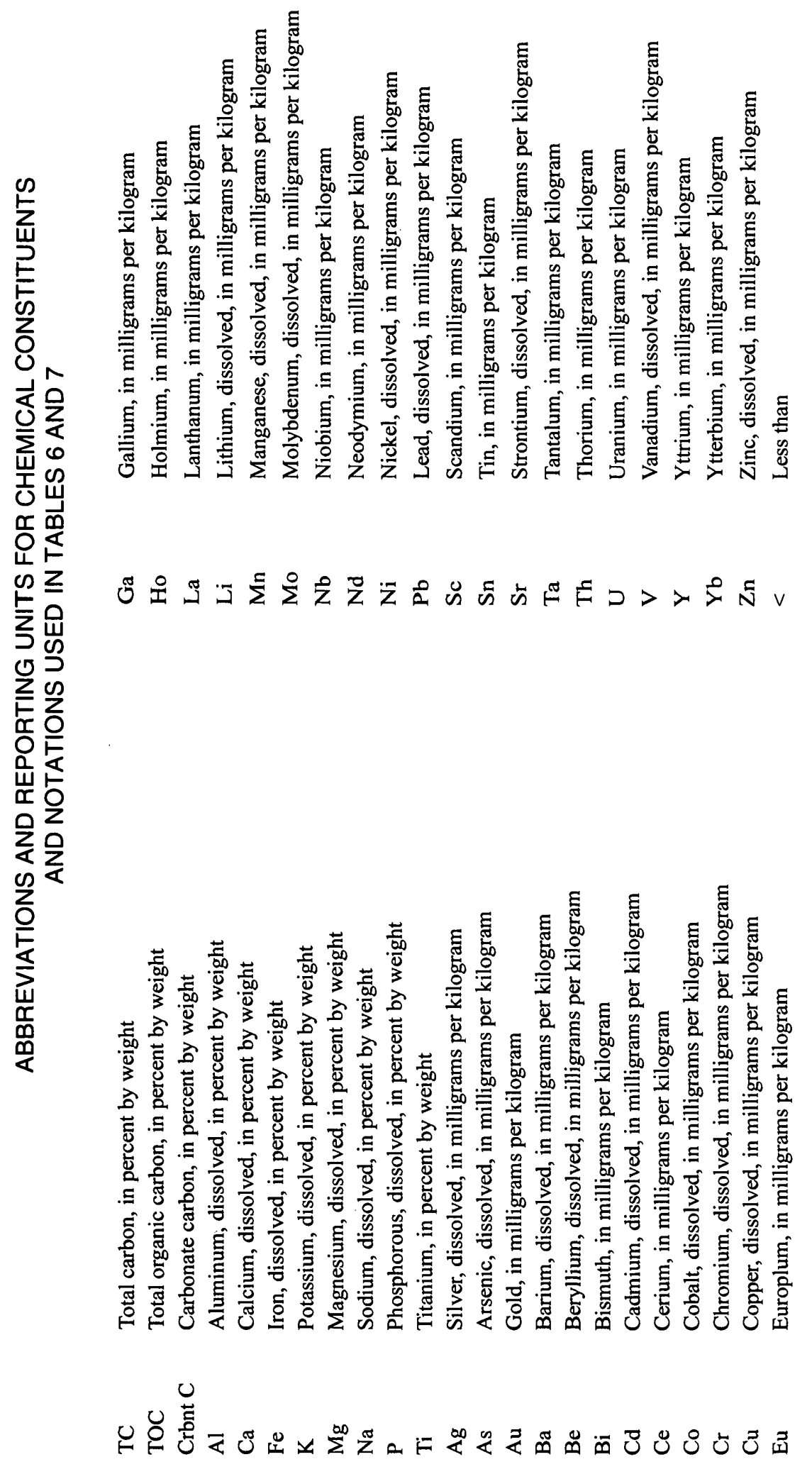




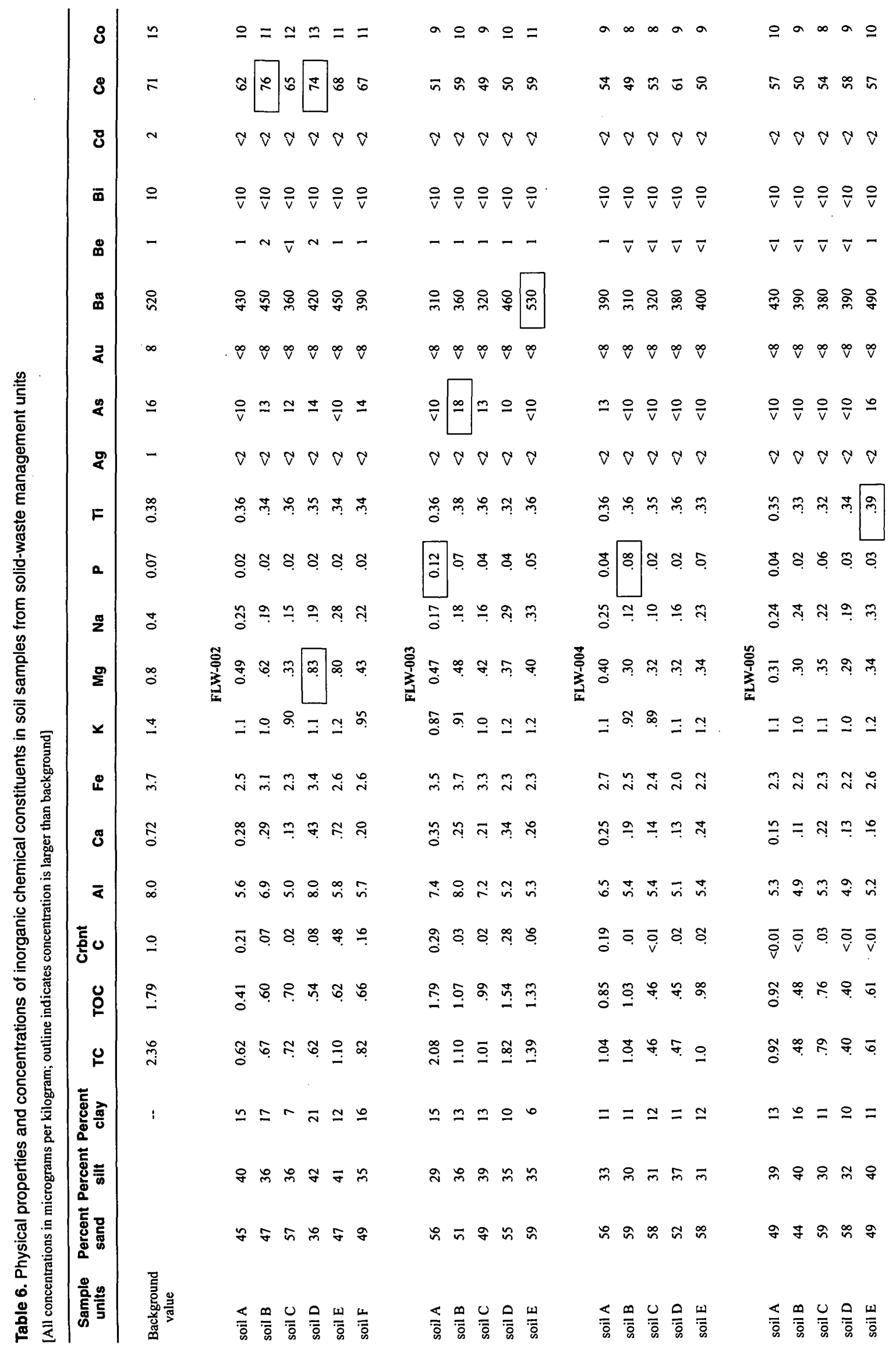




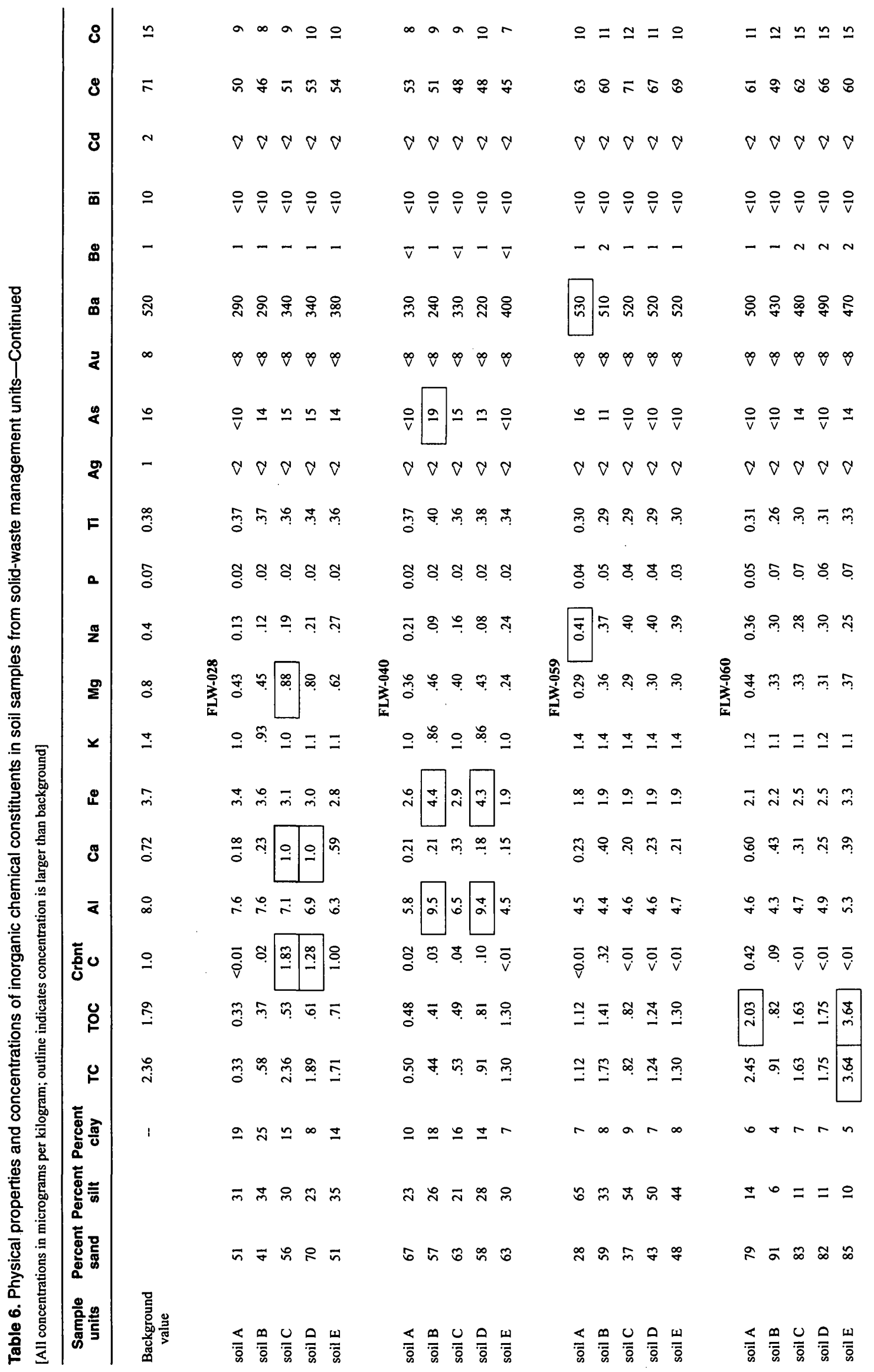




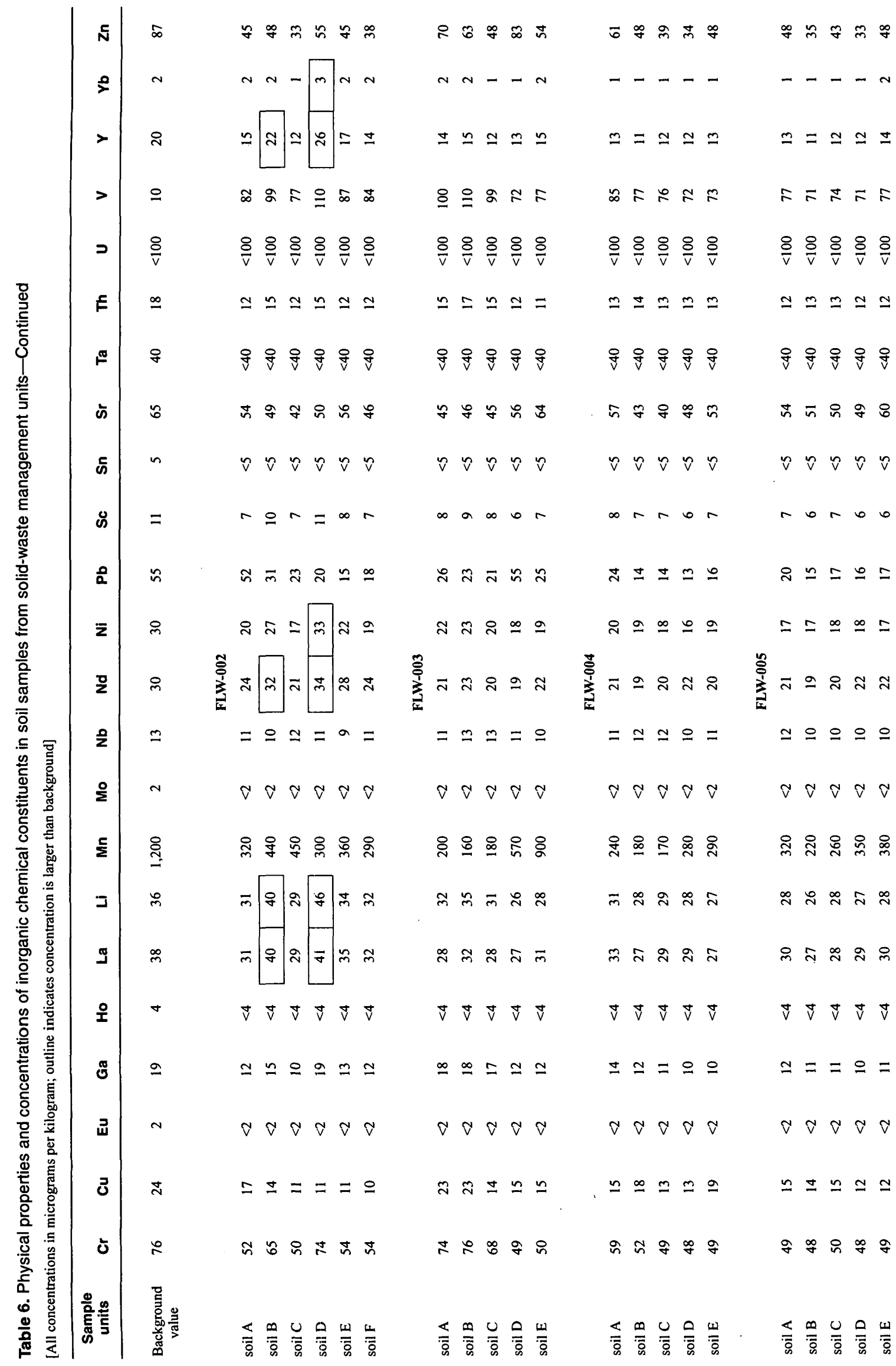




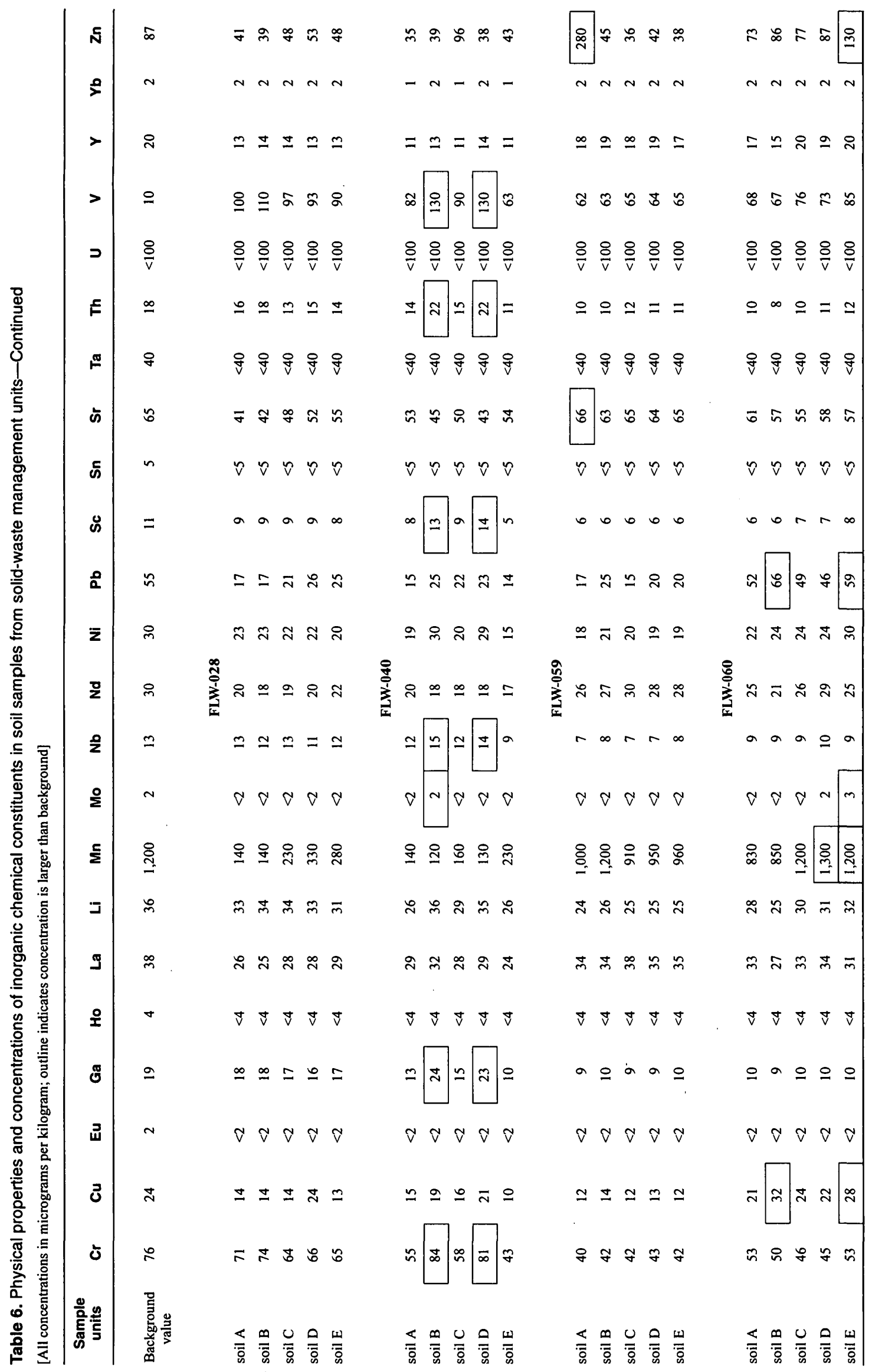




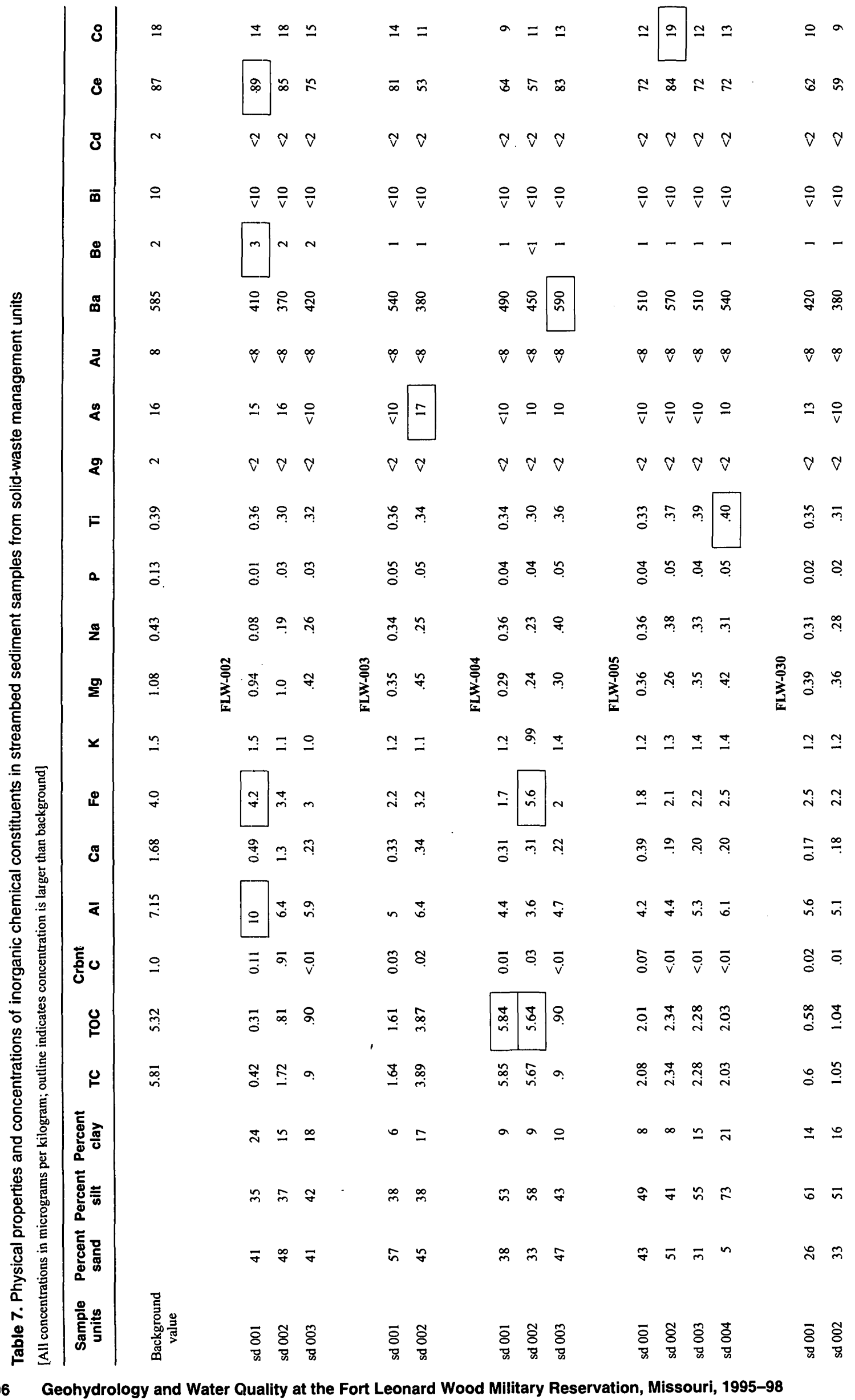




\begin{tabular}{|c|c|c|c|c|c|c|c|c|c|c|c|c|c|c|c|c|c|c|}
\hline & 8 & $\stackrel{\infty}{-}$ & & $\simeq \subseteq$ & $a$ & & $\infty$ & 은 & & $a$ & $\bullet$ & & $=$ & $\simeq$ & $a$ & & $\simeq \leq$ & $\underline{0}$ \\
\hline & 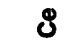 & $\bar{\infty}$ & $\approx$ & $\approx \delta$ & $N$ & & $\stackrel{\infty}{q}$ & $\stackrel{\infty}{n}$ & & $\bar{N}$ & $\approx$ & & $\stackrel{\infty}{\stackrel{1}{2}}$ & $\bar{\infty}$ & $\approx$ & $\infty$ & $\begin{array}{l}\infty \\
f\end{array}$ & $\approx$ \\
\hline & 8 & $N$ & & $\nabla \nabla$ & $\nabla$ & & $m$ & $\nabla$ & & $\nabla 0$ & $\nabla$ & & 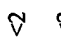 & $\nabla$ & $\sigma$ & $\sigma$ & $\begin{array}{lll}* & 0\end{array}$ & $\nabla$ \\
\hline & $\overline{\mathbf{D}}$ & ㅇ & & $\stackrel{\circ}{\mathrm{v}} \stackrel{\circ}{\mathrm{v}}$ & $\frac{\mathrm{O}}{\mathrm{v}}$ & & $\stackrel{\circ}{\mathrm{v}}$ & $\stackrel{\circ}{\mathrm{V}}$ & & $\stackrel{\circ}{v}$ & $\stackrel{\circ}{v}$ & & $\frac{O}{v}$ & $\stackrel{\circ}{v}$ & $\stackrel{\circ}{\mathrm{V}}$ & $\stackrel{\circ}{v}$ & $\frac{c}{v} \quad \frac{c}{v}$ & $\frac{\mathrm{q}}{\mathrm{v}}$ \\
\hline & ळ & $N$ & $\sim$ & $\sim \quad \nabla$ & $N$ & & - & - & & $\bar{v} \quad \bar{v}$ & $\bar{v}$ & & - & - & - & $\sim$ & $N$ & $N$ \\
\hline$\frac{\dot{s}}{2}$ & జ็ & $\stackrel{\check{\infty}}{n}$ & 8 & $\begin{array}{l}8 \\
\forall\end{array}$ & 字 & & శ్లి & : & & స్లి & $\stackrel{\infty}{~}$ & & ถี & 品 & $\stackrel{\infty}{\&}$ & g & $\stackrel{8}{g}$ & $\frac{\varrho}{\sigma}$ \\
\hline & $z$ & $\infty$ & $\infty$ & $\infty \quad \infty$ & $\stackrel{\infty}{\vee}$ & & $\stackrel{\infty}{\vee}$ & $\stackrel{\infty}{v}$ & & $\stackrel{\infty}{v}$ & $\stackrel{\infty}{v}$ & & $\infty$ & $\stackrel{\infty}{v}$ & $\stackrel{\infty}{v}$ & & $\infty \quad \alpha$ & $\infty$ \\
\hline$\stackrel{\bar{\Xi}}{\varepsilon}$ & 8 & $\underline{\underline{ }}$ & $\stackrel{\circ}{v}$ & $\frac{\circ}{v} \simeq$ & $\frac{O}{v}$ & & $\stackrel{\circ}{0}$ & $\Xi$ & & $\stackrel{\circ}{v}$ & $\stackrel{\circ}{v}$ & & $\frac{\circ}{\mathrm{v}}$ & $\stackrel{\circ}{v}$ & $\stackrel{\circ}{\mathrm{v}}$ & & $\approx=$ & $\simeq$ \\
\hline & 8 & $\sim$ & v & $\nabla \nabla$ & $\nabla$ & & $\nabla$ & $\nabla$ & & $\nabla 0$ & $\nabla$ & & 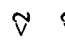 & $\nabla$ & $\nabla$ & $\tilde{v}$ & $\vec{v} \quad$ & $v$ \\
\hline$\xi$ & $F$ & ర్యి & స్రి & స్రి & $\bar{m}$ & & $\stackrel{\text { }}{0}$ & $\bar{m}$ & & ্ֻণি: & ले & & స్ & ㅁํ & $\bar{m}$ & & $\begin{array}{l}0 \\
0 \\
0\end{array}$ & গ̣ \\
\hline & $a$ & $\stackrel{m}{0}$ & $\stackrel{\circ}{\circ}$ & $\begin{array}{l}\overbrace{0} \\
\end{array}$ & $\stackrel{\infty}{0}$ & & $\frac{\pi}{0}$ & $\stackrel{\infty}{\circ}$ & & $\underset{0}{0} 8$ & ธิ & & $\stackrel{0}{0}$ & पे. & 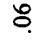 & $\stackrel{a}{0}$ & : & จุ \\
\hline & $\frac{\pi}{2}$ & fo & న్ & స్ ఫิ ₹ & 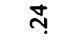 & & స్ & \begin{tabular}{|l|}
$\stackrel{\infty}{*}$ \\
$\stackrel{5}{*}$
\end{tabular} & & $\stackrel{\infty}{0}$ & ণ্ & & go & $\overline{7}$ & $\bar{y}$ & $\stackrel{\widetilde{m}}{0}$ & c్ & ঙ̣ \\
\hline 8 & I) & $\stackrel{\circ}{\stackrel{0}{\longrightarrow}}$ & 搴 & 我 & $\bar{n}$ & 浐 & $\tilde{N}$ & $\exists$ & 辛 & & $\cong$ & 商 & $\tilde{\Xi}$ & ণ & $\tilde{A}$ & : & 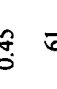 & $\overline{0}$ \\
\hline & $x$ & $\because$ & 9 & $=?$ & ? & & ôे & $\cong$ & & ô & $\hat{a}$ & & $\cong$ & \pm & \pm & & $m s$ & 요 \\
\hline 言 & L̊ & $\stackrel{\circ}{+}$ & $\tilde{\sim}$ & $\tilde{i}$ & $\tilde{N}$ & & $\tilde{N}$ & $\tilde{\sim}$ & & $\stackrel{\sim}{\sim}:$ & 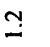 & & 9 & $\stackrel{\infty}{-}$ & $\stackrel{\circ}{=}$ & $\tilde{\sim}$ & $\tilde{N}$ & $\stackrel{\text { i }}{\text { in }}$ \\
\hline 矛 & తూ & $\stackrel{\infty}{\stackrel{\circ}{-}}$ & $\stackrel{0}{0}$ & $\overbrace{0}^{0}$ & जे & & \begin{tabular}{|l|}
$\infty$ \\
$\dot{m}$
\end{tabular} & $\stackrel{\infty}{-}$ & & సิ & $\fallingdotseq$ & & $\bar{\Xi}$ & শ্ড & $\widetilde{\widetilde{r}}$ & $\stackrel{8}{0}$ & $\begin{array}{l}f_{0}^{0} \\
0\end{array}$ & $\stackrel{\infty}{?}$ \\
\hline$\overline{\underline{z}}$ & $\bar{\alpha}$ & $\stackrel{n}{\sim}$ & $\bar{n}$ & $\vec{n} \quad \vec{m}$ & $\tilde{i n}$ & & ले & $\tilde{n}$ & & $\stackrel{\circ}{\dot{n}}:$ & స్ల & & 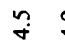 & F & $\underset{\forall}{\mathscr{J}}$ & $\stackrel{\circ}{n}$ & 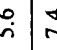 & $\stackrel{\Delta}{r}$ \\
\hline 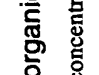 & 总 & $\stackrel{\circ}{-}$ & \% & 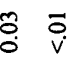 & $\overrightarrow{\dot{v}}$ & & $\stackrel{\widetilde{\sigma}}{-}$ & $\stackrel{\circ}{\circ}$ & & $\stackrel{0}{0}$ & $\vec{o}$ & & $\begin{array}{l}\overline{0} \\
\dot{\vec{b}}\end{array}$ & ธี & $\overrightarrow{\stackrel{a}{v}}$ & 3 & 5 & ণి \\
\hline 总 & \& & $\tilde{\tilde{n}}$ & 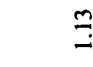 & $\cong \stackrel{\infty}{\rightarrow}$ & $\stackrel{\leftrightarrow}{-}$ & & $\bar{y}$ & 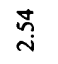 & & 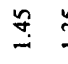 & $\stackrel{n}{g}$ & & $\stackrel{q}{-}$ & $\infty$ & $\frac{a}{m}$ & $\stackrel{\infty}{\stackrel{0}{0}}$ & ఫ্ & స్తి \\
\hline 焉 & i & $\stackrel{\bar{\infty}}{\dot{n}}$ & $\stackrel{\circ}{=}$ & $\cong \stackrel{\infty}{\sim}$ & $\stackrel{\leftrightarrow}{\circ}$ & & बे & $\stackrel{\bar{n}}{m}$ & & $\stackrel{\infty}{\stackrel{\infty}{:}}$ & $\stackrel{m}{g}$ & & $\stackrel{F}{Z}$ & 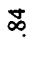 & $\stackrel{\text { mे }}{\text { m }}$ & $\ddot{0}$ & $\stackrel{8}{0}:$ & $\stackrel{g}{g}$ \\
\hline 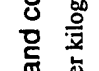 & 递 $\frac{\widehat{\sigma}}{0}$ & & $m$ & $m+$ & $N$ & & $r$ & $n$ & & $r$ & r & & \pm & $\simeq$ & $=$ & 0 & 6 & $\sigma$ \\
\hline 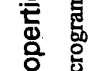 & 这 & & $\sigma$ & $\forall F$ & $N$ & & $m$ & $r$ & & $\underline{0}$ & $\ddot{N}$ & & $m$ & $g$ & $\mathcal{F}$ & $\underline{m}$ & $m$ ? & $N$ \\
\hline 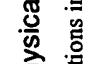 & 这 & & & 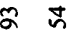 & 2 & & $\bar{\infty}$ & வे & & $\approx$ & b & & $m$ & q & $F$ & & $5:$ & Бু \\
\hline 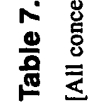 & 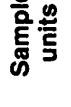 & 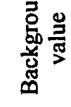 & & $\begin{array}{ll}\overline{8} & \overline{0} \\
\bar{\varpi} & \overline{0}\end{array}$ & $\begin{array}{l}\tilde{\delta} \\
\bar{y}\end{array}$ & & $\begin{array}{l}\overline{8} \\
\bar{\square}\end{array}$ & $\begin{array}{l}\text { ठิ } \\
\bar{\varpi}\end{array}$ & & $\overline{\bar{\delta}}$ & $\begin{array}{l}\text { ठิ } \\
\bar{\nabla}\end{array}$ & & $\begin{array}{l}\bar{\delta} \\
\bar{v}\end{array}$ & 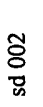 & 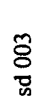 & 혐 & $\begin{array}{c}\delta \\
\bar{c} \\
\bar{c}\end{array}$ & 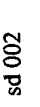 \\
\hline
\end{tabular}




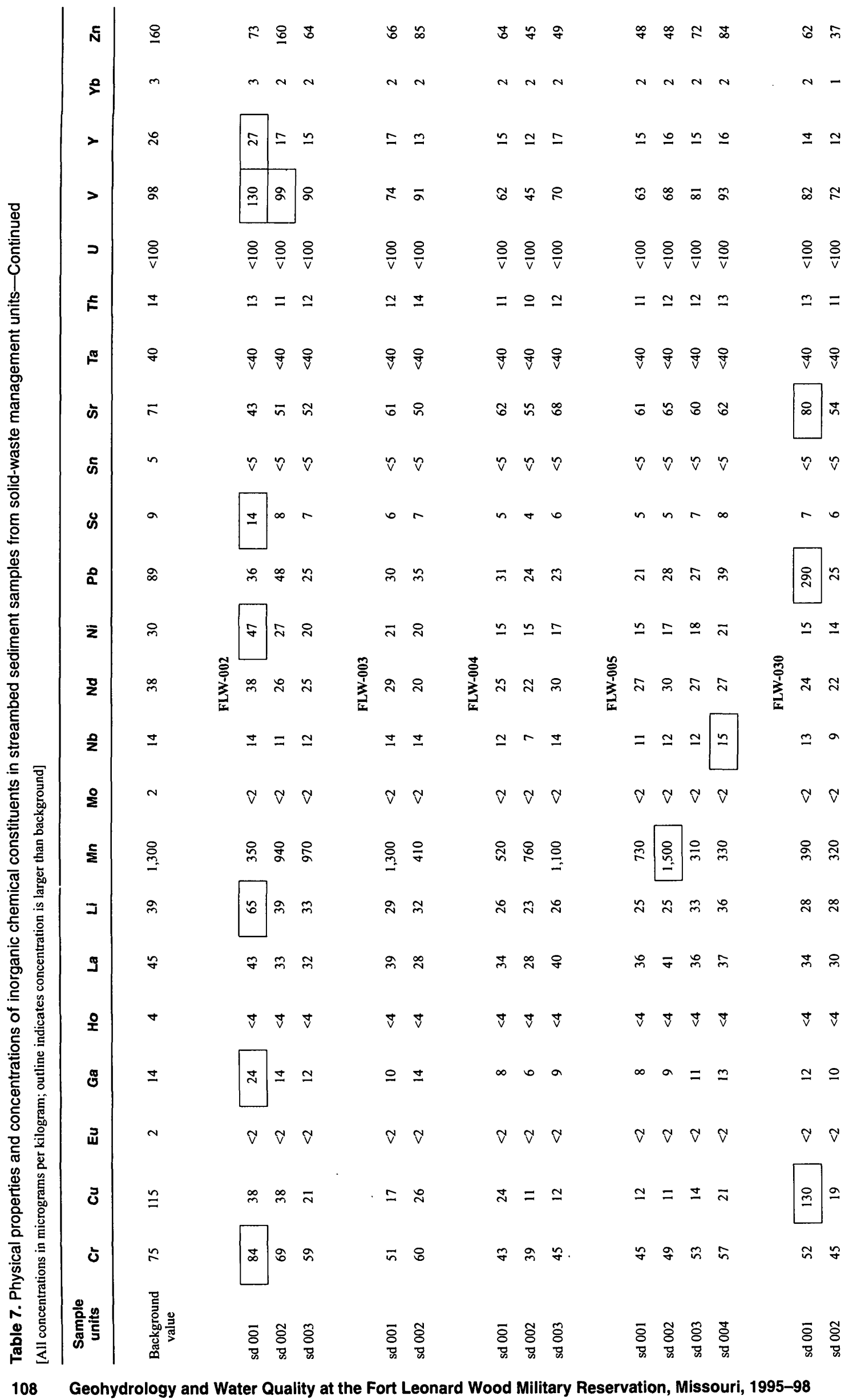




\begin{tabular}{|c|c|c|c|c|c|c|c|c|c|c|c|c|c|c|c|}
\hline & 5 & $\ddot{8}$ & ที & 犗 & 8 & & $\begin{array}{l}\text { : } \\
\end{array}$ & b & 8 & F & & 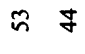 & 8 & $\infty$ & $: \stackrel{8}{\circ}$ \\
\hline & 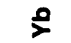 & $m$ & & $N-$ & $m$ & & $-n$ & $v$ & - & - & & $N N$ & $N$ & $\sim$ & $N N$ \\
\hline & $>$ & $\stackrel{\sim}{\sim}$ & & $\bar{\sim} \cong$ & 吕 & & $\simeq \cong$ & 2 & $\underline{m}$ & $\simeq$ & & $\stackrel{\infty}{\simeq} \stackrel{\infty}{ }$ & $\stackrel{\infty}{ }$ & ๗ & $\bar{\lambda}$ \\
\hline & $>$ & $\approx$ & & $\approx$ \& & $\infty$ & & $\approx \approx$ & $n$ & 2 & P & & $8 \%$ & $i$ & $\bar{\infty}$ & $\infty \infty$ \\
\hline రુ & כ & $\frac{8}{v}$ & & $\frac{8}{\mathrm{v}} \stackrel{8}{\mathrm{v}}$ & $\frac{8}{v}$ & & $\frac{8}{v} \quad \frac{8}{v}$ & $\frac{8}{v}$ & $\frac{8}{v}$ & $\frac{g}{v}$ & & $\frac{O}{v} \frac{g}{v}$ & $\frac{\mathrm{g}}{\mathrm{V}}$ & $\frac{8}{v}$ & $\frac{8}{v}$ \\
\hline 密 & $E$ & $\Xi$ & & $\simeq \sigma$ & $=$ & & $r=$ & $=$ & $\Xi$ & 임 & & $=0$ & $\varrho$ & $=$ & $= \pm$ \\
\hline छ్ & ๘ & $q$ & & $\begin{array}{l}P \\
V\end{array}$ & P & & I & i & div & o & & $\stackrel{P}{P}$ & P & i & i \\
\hline हृ & ì & $\pi$ & & $\approx \approx$ & $\approx$ & & 85 & o & $\bar{n}$ & $\tilde{n}$ & & 68 & $\ddot{6}$ & $\widetilde{\sigma}$ & $\tilde{\sigma})$ \\
\hline 3 & હ & $n$ & & $\vartheta \approx$ & $\vartheta$ & & $\vartheta \vartheta$ & 0 & $\tilde{v}$ & $\tilde{v}$ & & $\tilde{v} \tilde{v}$ & $\hat{v}$ & $\vartheta$ & $\hat{\vartheta} \vartheta$ \\
\hline Ĕ & ॐ & $a$ & & $r \quad \sigma$ & $\infty$ & & $n r$ & - & r & $\sigma$ & & $0 \mathrm{n}$ & $n$ & & $\infty a$ \\
\hline$\overline{\mathrm{g}}$ & $\stackrel{0}{a}$ & $\infty$ & & 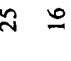 & iิ & & $\stackrel{2}{\sim}$ & : & $\stackrel{\infty}{\sim}$ & $\simeq$ & & $\stackrel{\sim}{i}$ & $\tilde{\pi}$ & iి & v \\
\hline$\widehat{\Phi}$ & $\overline{\mathbf{z}}$ & 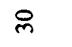 & & $\stackrel{2}{\sim}$ & ని & & $\stackrel{\sim}{\sim}$ & i & i & ㅇ & & 99 & $=$ & $\stackrel{\infty}{\sim}$ & is \\
\hline d & $\frac{0}{2}$ & $\stackrel{\infty}{m}$ & 感 & $\approx \approx$ & $\bar{n}$ & 商= & $=\pi$ & 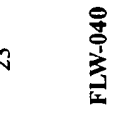 & ㅇ & $\approx$ & 突。 & $\tilde{m} \approx$ & ని & 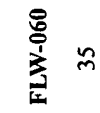 & $n \approx$ \\
\hline & $\frac{0}{2}$ & \pm & & $\simeq=$ & $=$ & & $\infty \simeq$ & $y$ & \pm & $=$ & & $\stackrel{9}{9}$ & $=$ & $\simeq$ & $y$ 은 \\
\hline 总 & 올 & $N$ & & $\widetilde{v} \quad \nabla$ & $\sigma$ & & $\nabla \nabla$ & y & $\vec{v}$ & $\sigma$ & & $\tilde{v} \tilde{v}$ & v & 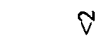 & $v \quad v$ \\
\hline ¿ & $\frac{\Gamma}{\Sigma}$ & 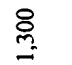 & & $\stackrel{\infty}{2}$ & $\stackrel{\mathscr{D}}{\sim}$ & & \& & D & $\stackrel{\circ}{N}$ & 요 & & \& ڤ & $\frac{0}{6}$ & 익 & : \\
\hline 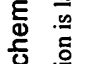 & ב & के & & $\dot{e} \bar{N}$ & "̈ & & $\approx$ i & b & $\stackrel{\infty}{\sim}$ & 9 & & $\ddot{\sim}$ & $\tilde{\lambda}$ & ల్ల & i \\
\hline & $\Xi$ & $q$ & & $\begin{array}{l}* \\
\end{array}$ & $\because$ & & $\approx \approx$ & n & సి & 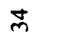 & & $q F$ & $\stackrel{\infty}{m}$ & $\vartheta$ & 8 \\
\hline ¿ั & 오 & $\sigma$ & & $\vec{v} \quad \vec{v}$ & $\vec{\nabla}$ & & $\vec{V} \quad \vec{\nabla}$ & y & $\vec{v}$ & $\checkmark$ & & $\vec{v} \quad \vec{v}$ & $\vec{v}$ & $\vec{v}$ & $\dot{v}$ \\
\hline 焉 & ङீ & \pm & & $=r$ & $\simeq$ & & $a=$ & $E$ & $\simeq$ & $\circ$ & & $a \infty$ & $\infty$ & $=$ & $=m$ \\
\hline 它 & 己ื & $N$ & & $\sigma \quad \nabla$ & $\sigma$ & & $\nabla \nabla$ & v & $\widetilde{v}$ & v & & $\tilde{v} \nabla$ & v & V & $v \quad v$ \\
\hline 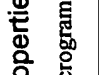 & ठె & $\cong$ & & $\simeq$ & $\approx$ & & $\stackrel{\circ}{\circ}=$ & $F$ & $\approx$ & $\ddot{0}$ & & $=2$ & $\simeq$ & ㅇ & i \\
\hline 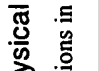 & ๖̀ & $\approx$ & & 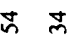 & 5 & & $\vec{\sigma} \approx$ & $\hat{n}$ & $\approx$ & gे & & $F F$ & $\bar{\sigma}$ & $\ddot{n}$ & $\delta=$ \\
\hline 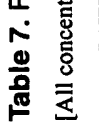 & 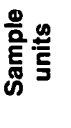 & 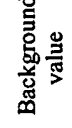 & & $\begin{array}{ll}\overline{8} & \tilde{0} \\
\bar{\varpi} & \bar{m}\end{array}$ & $\begin{array}{l}\tilde{8} \\
0 \\
0\end{array}$ & & 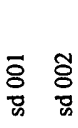 & 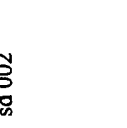 & $\begin{array}{l}\overline{8} \\
\overline{0}\end{array}$ & 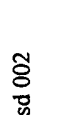 & & $\begin{array}{ll}\bar{\delta} & \bar{\delta} \\
\bar{x} & \bar{\phi}\end{array}$ & $\begin{array}{l}0 \\
0 \\
\bar{y}\end{array}$ & $\overline{8}$ & $\begin{array}{c}5 \\
\\
\\
\end{array}$ \\
\hline
\end{tabular}




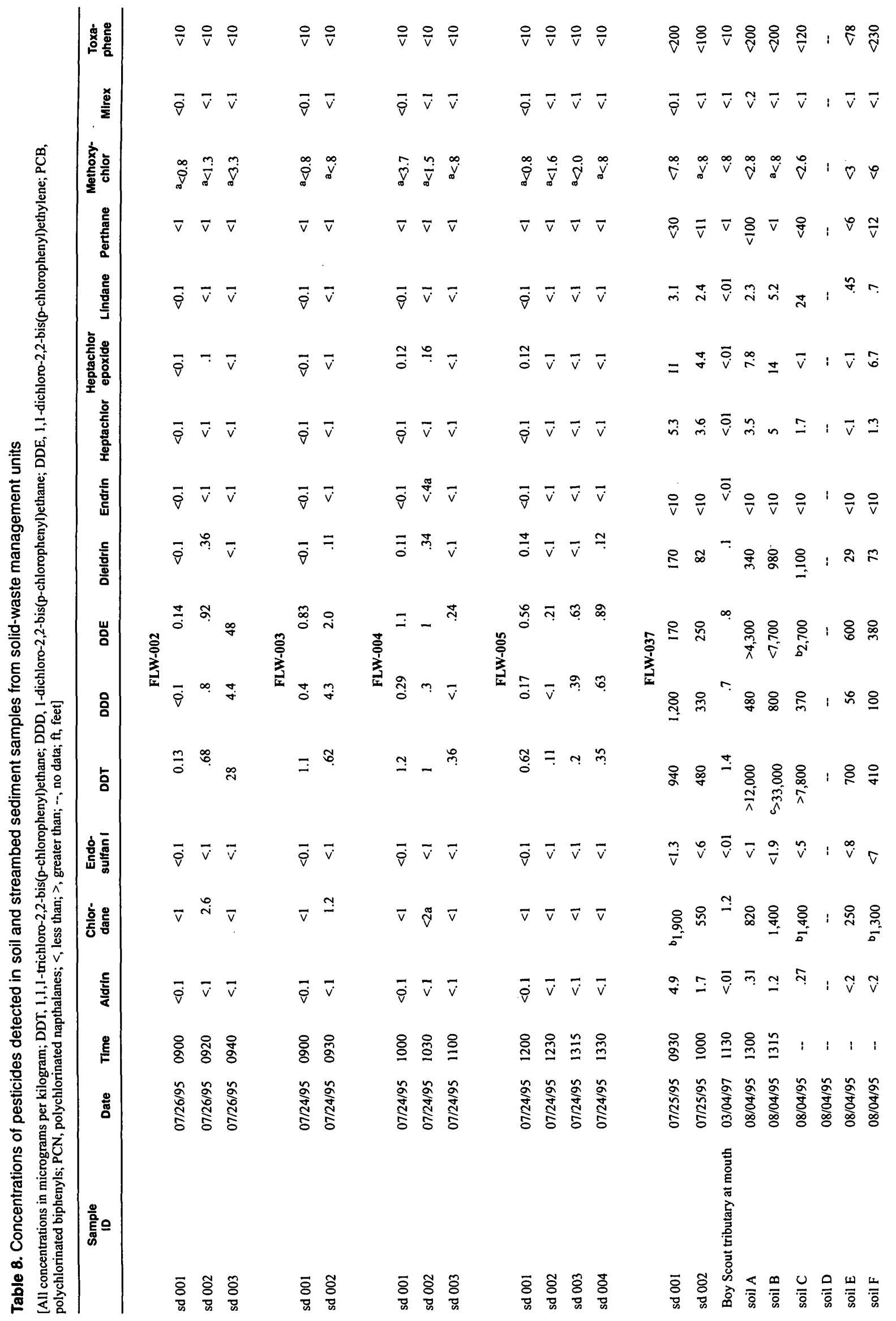




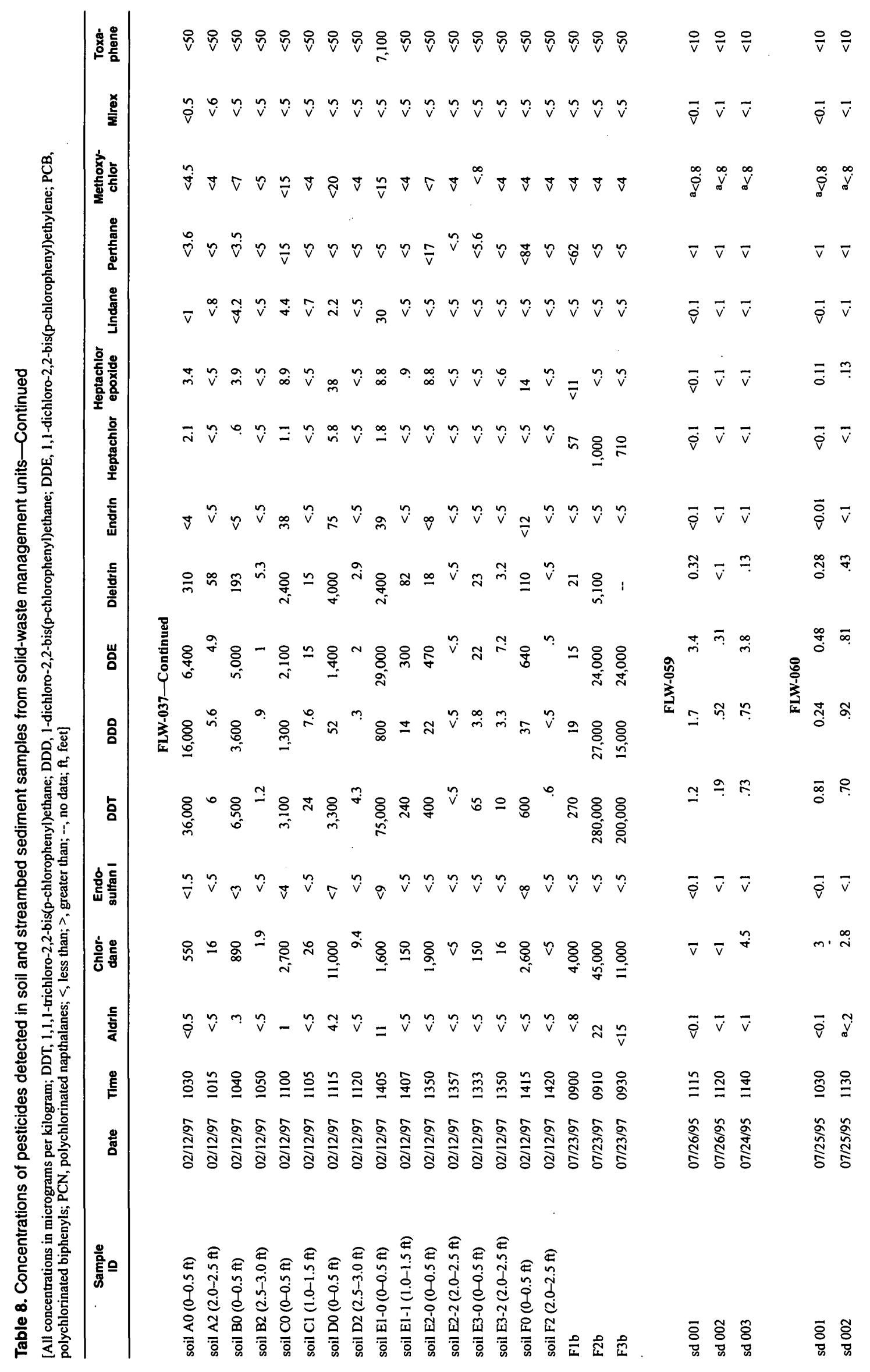




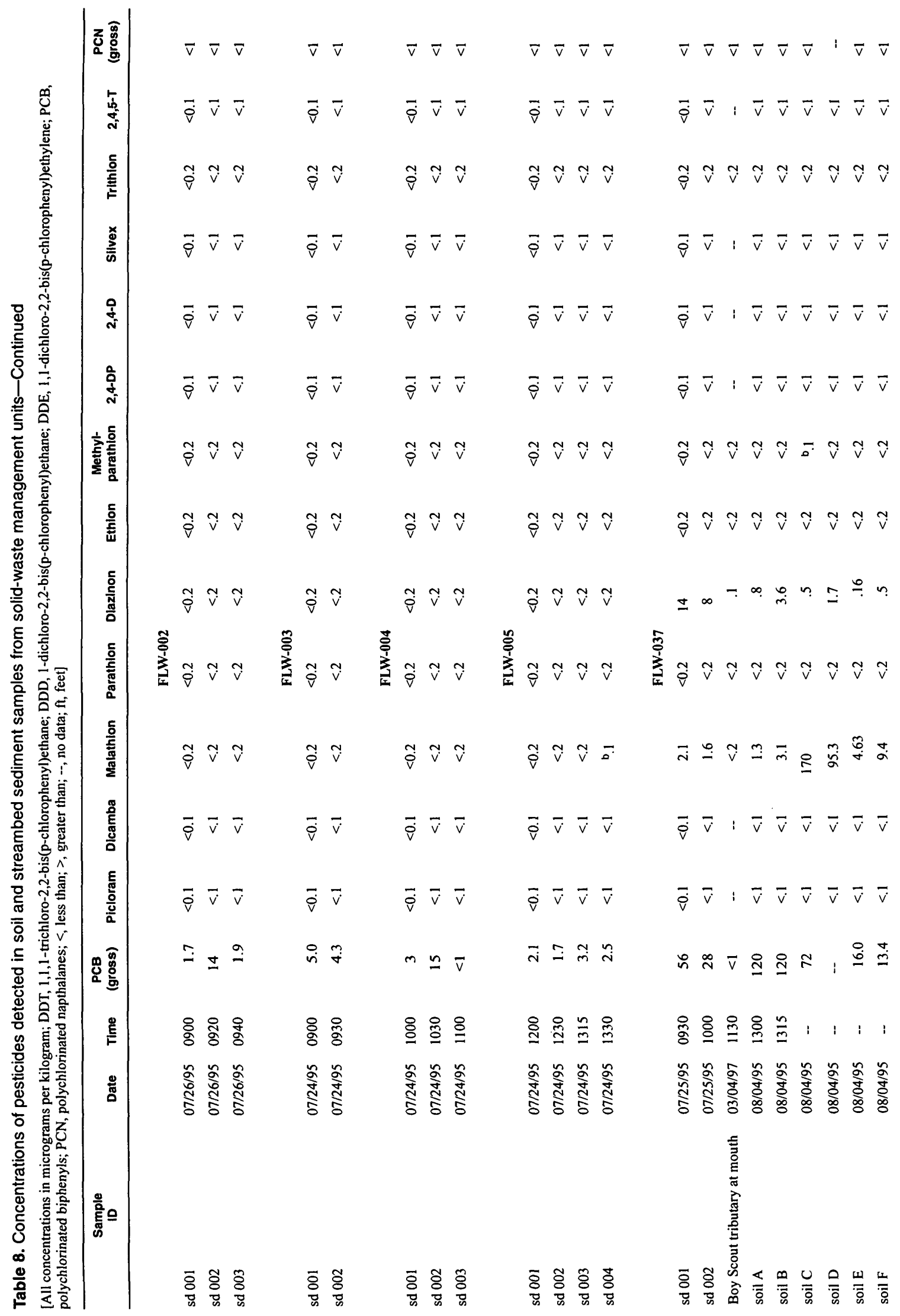




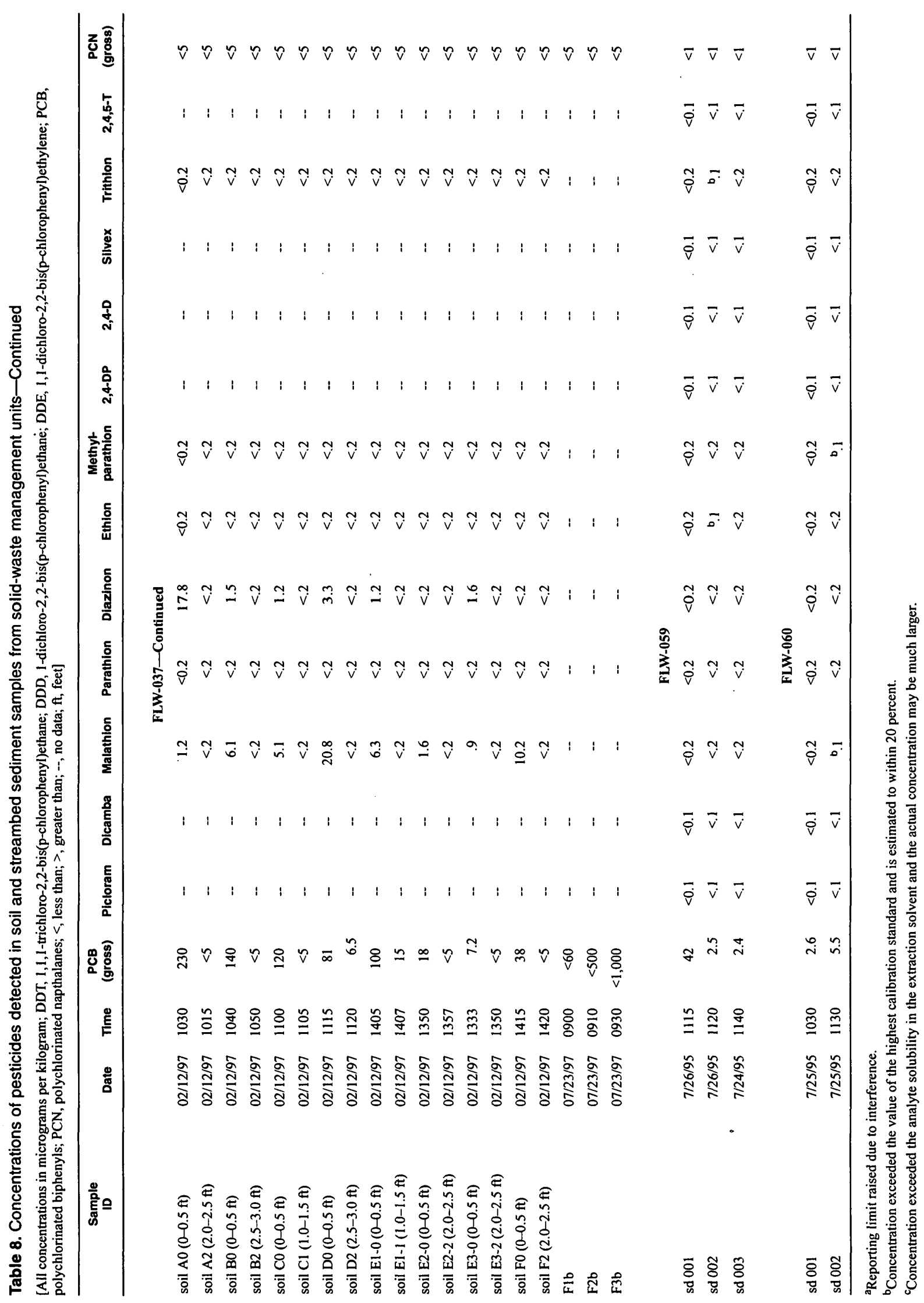




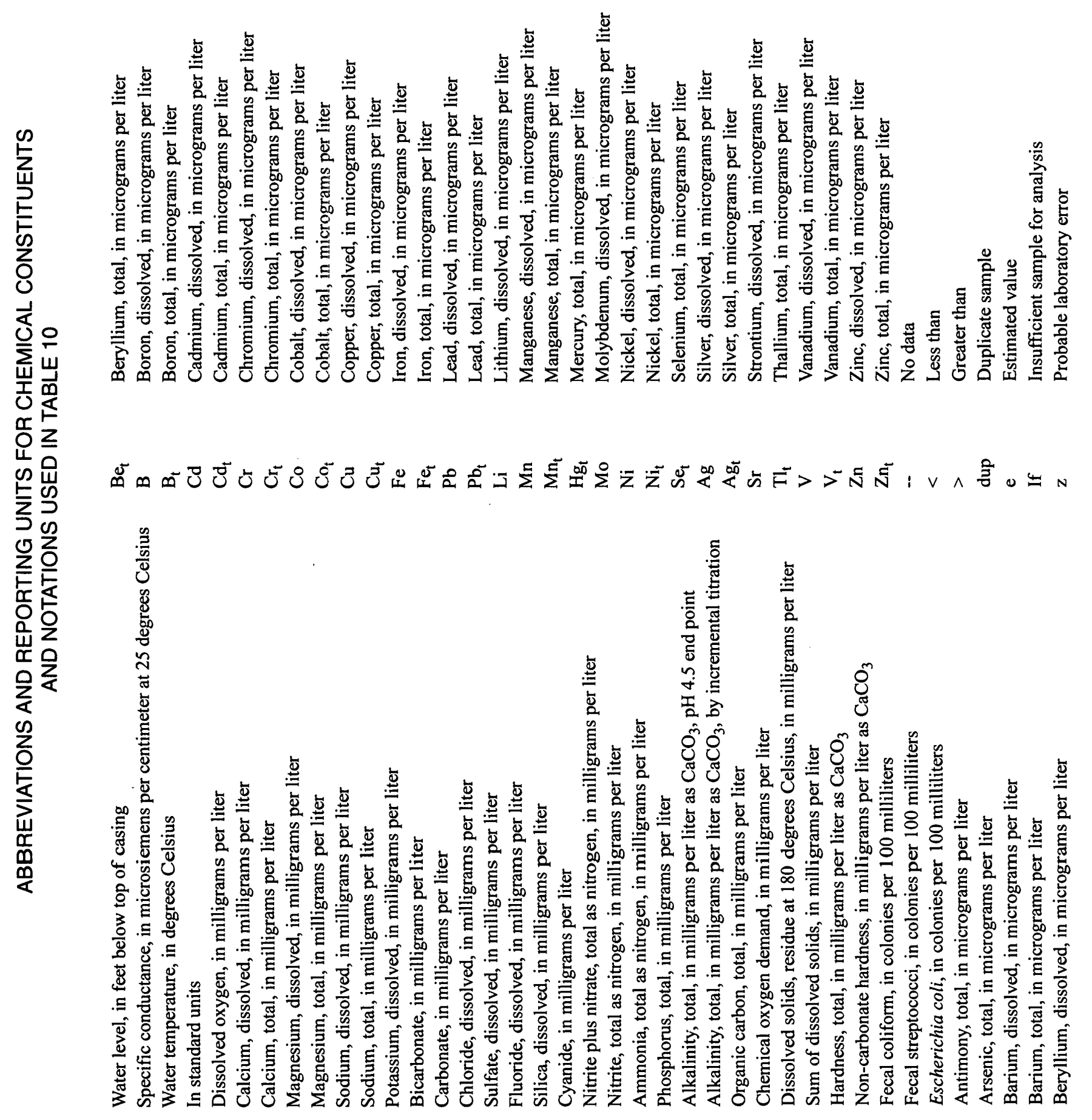

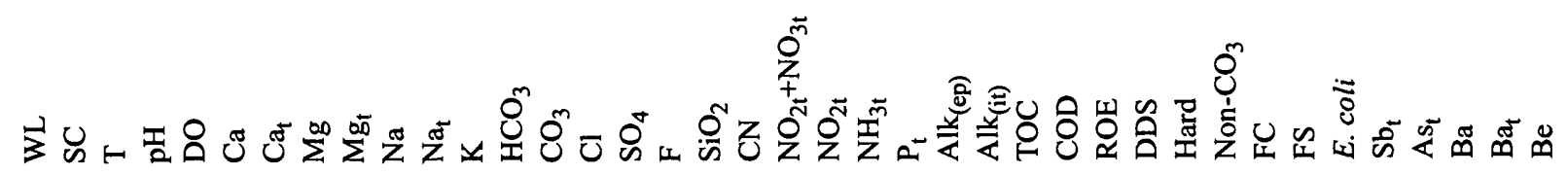




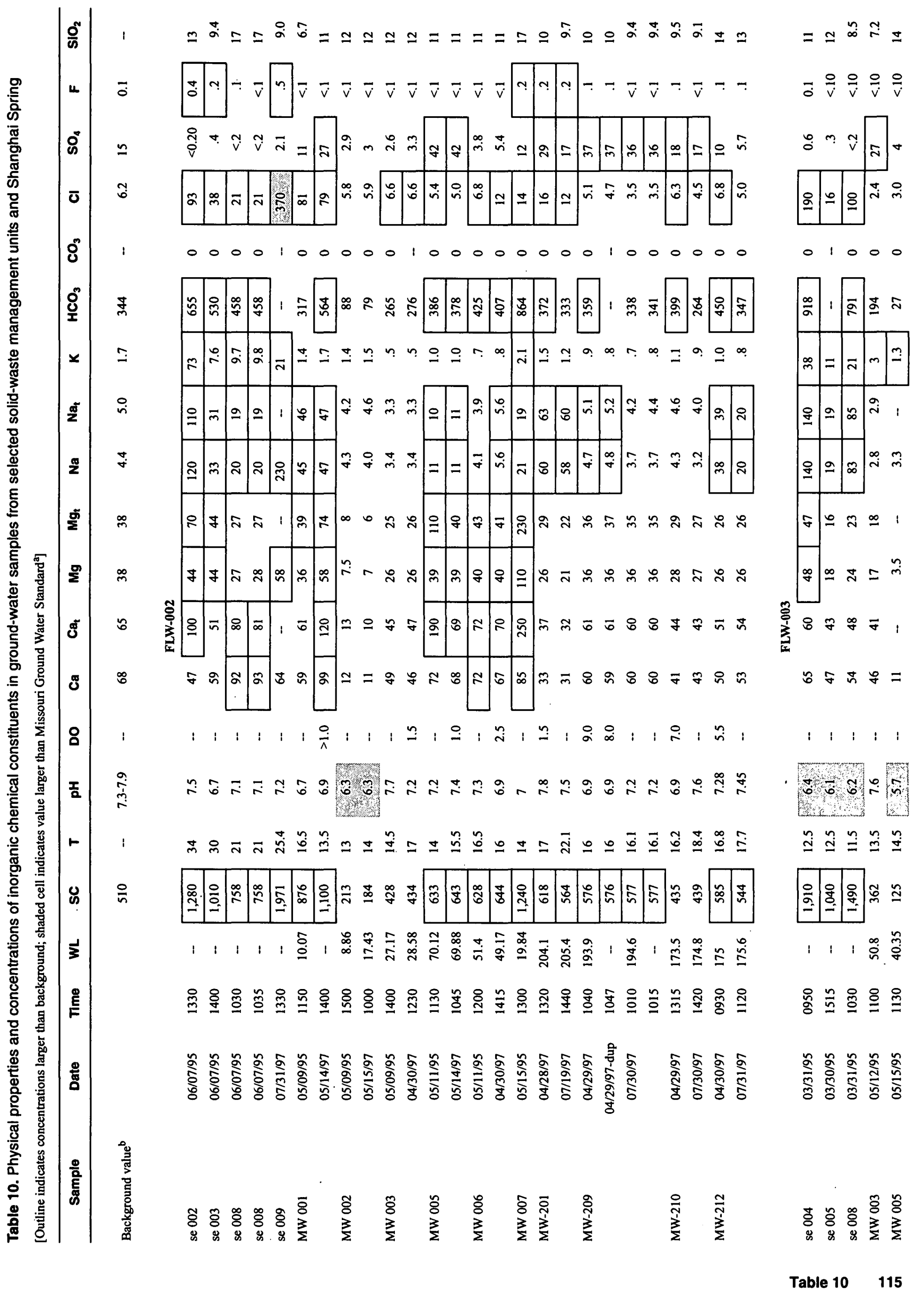




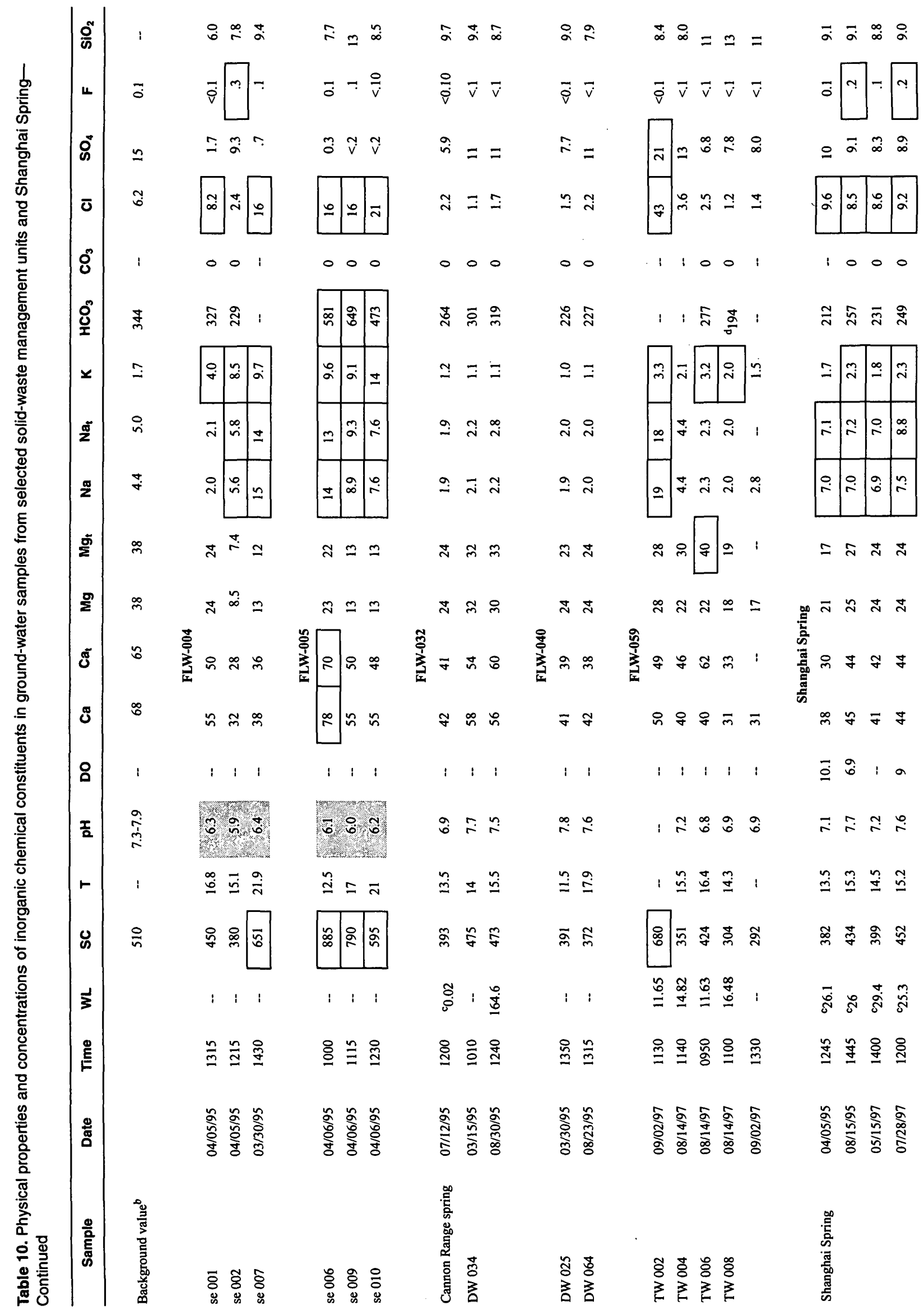




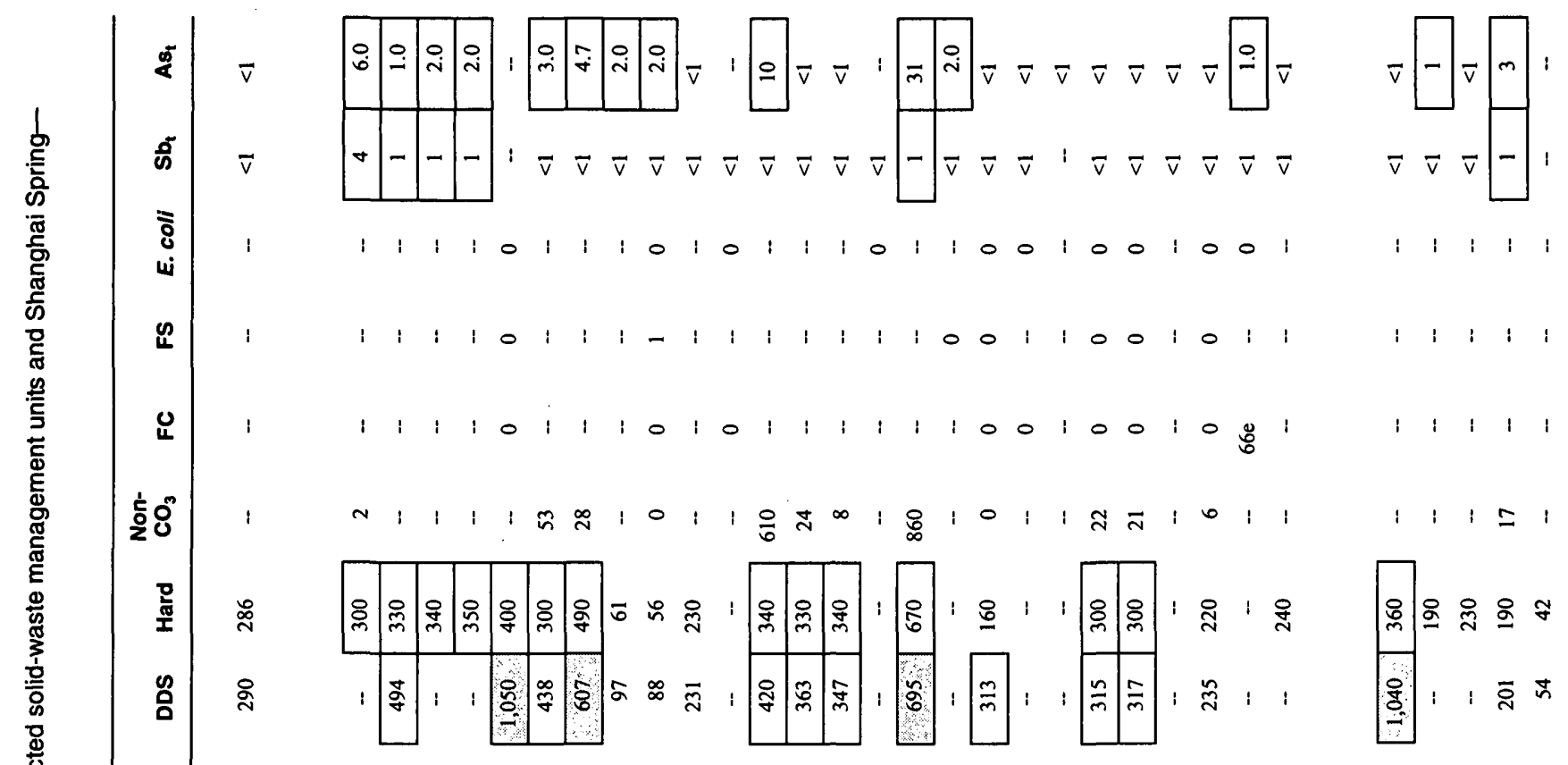

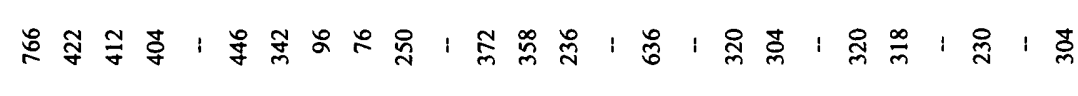

웅윶쥬 중

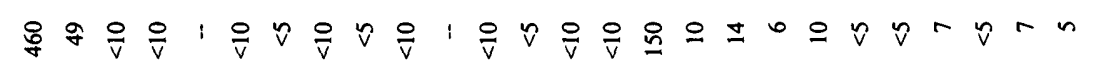

$\bar{n} \frac{\infty}{\sigma} \bar{n} \frac{0}{\mathrm{v}}$

$\stackrel{\infty}{\sim}$

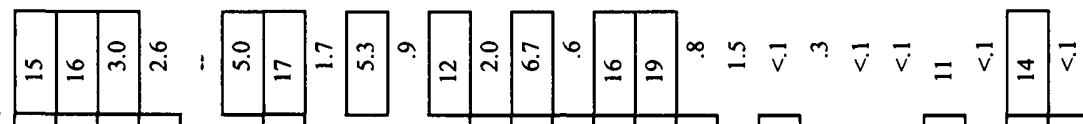

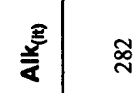

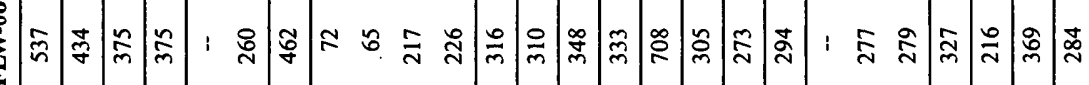

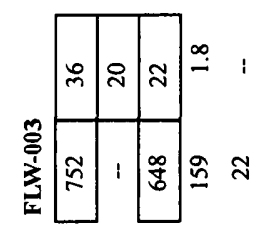

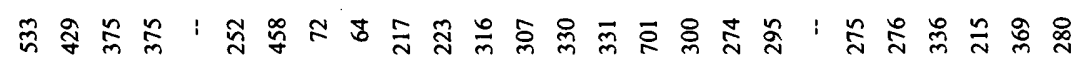

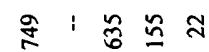

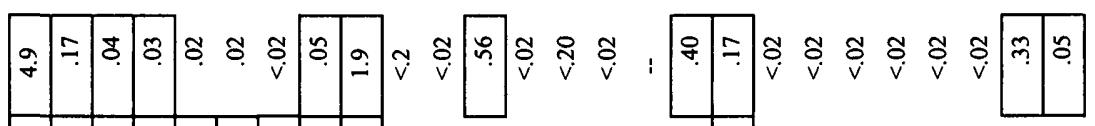

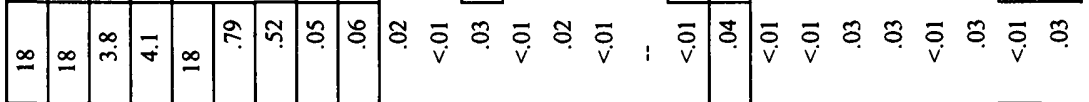

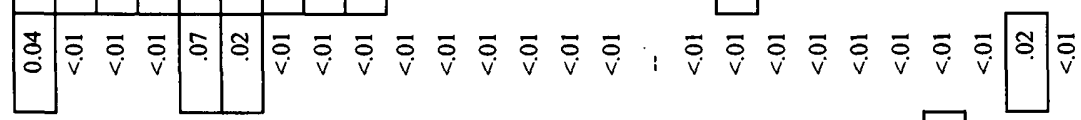

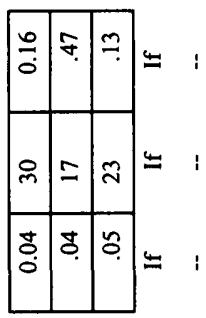

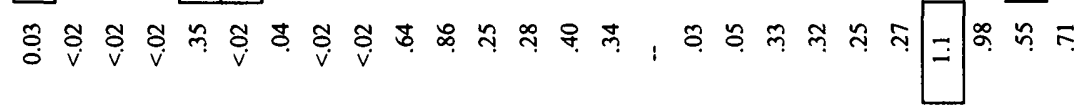

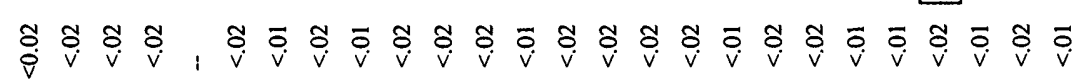

$\because 8- \pm 1$

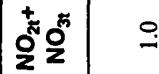

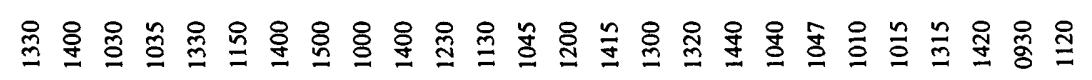

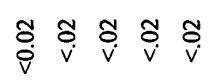

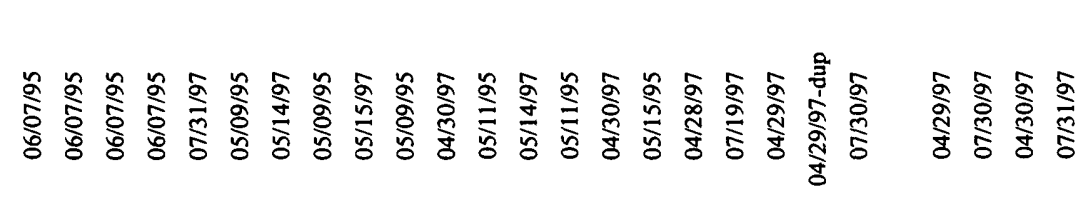

영 응용용용

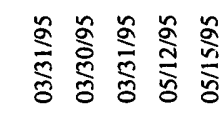




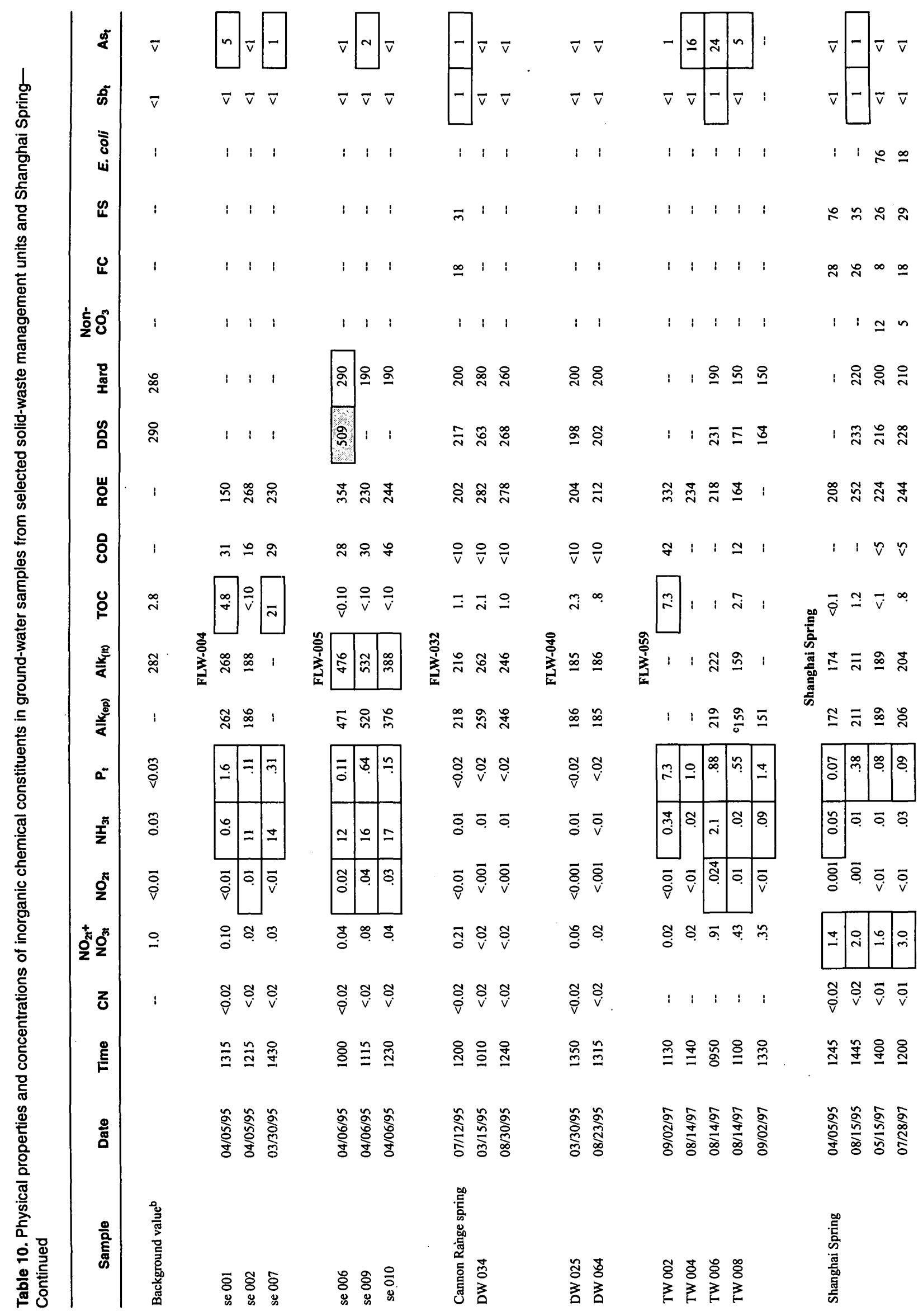




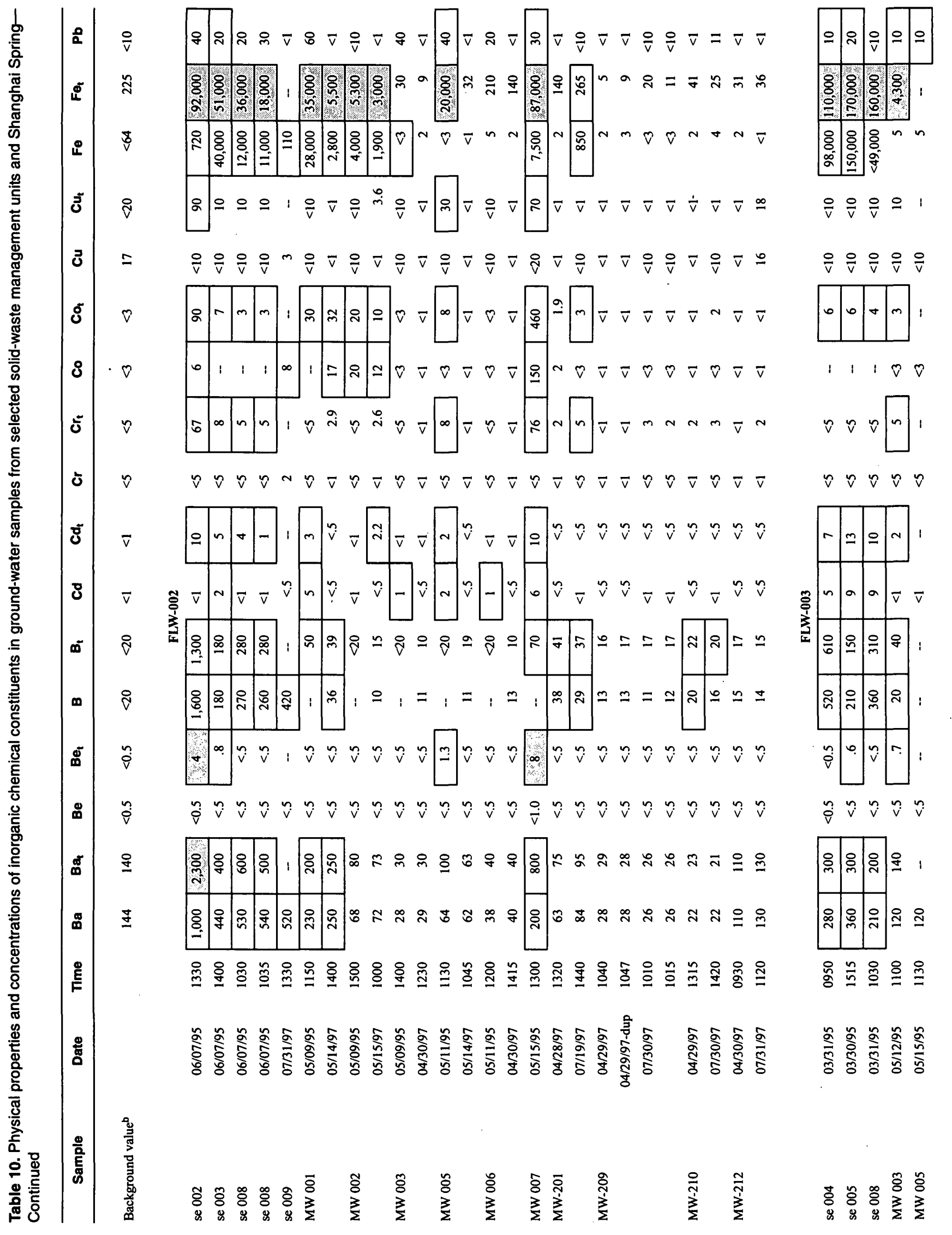




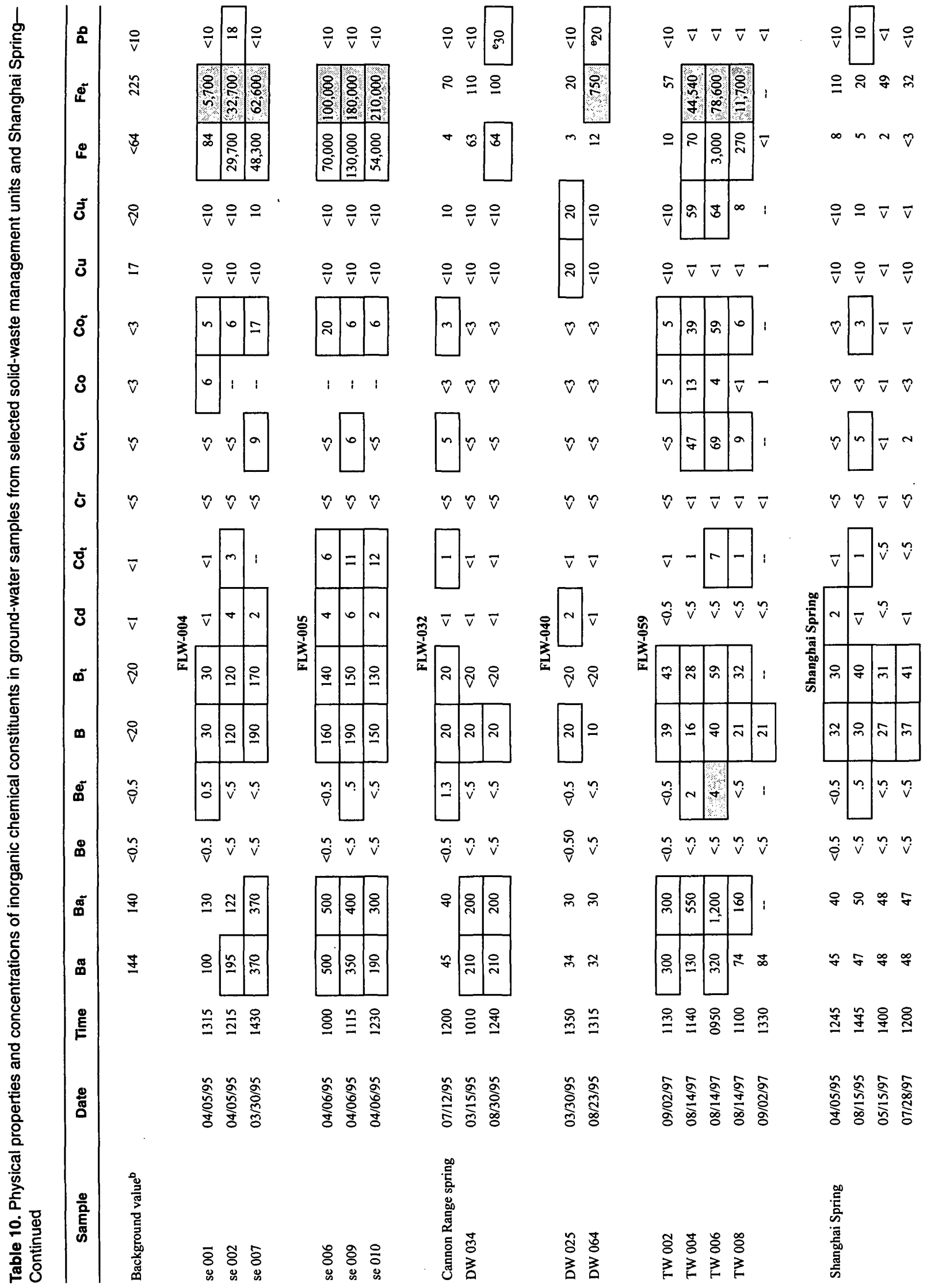




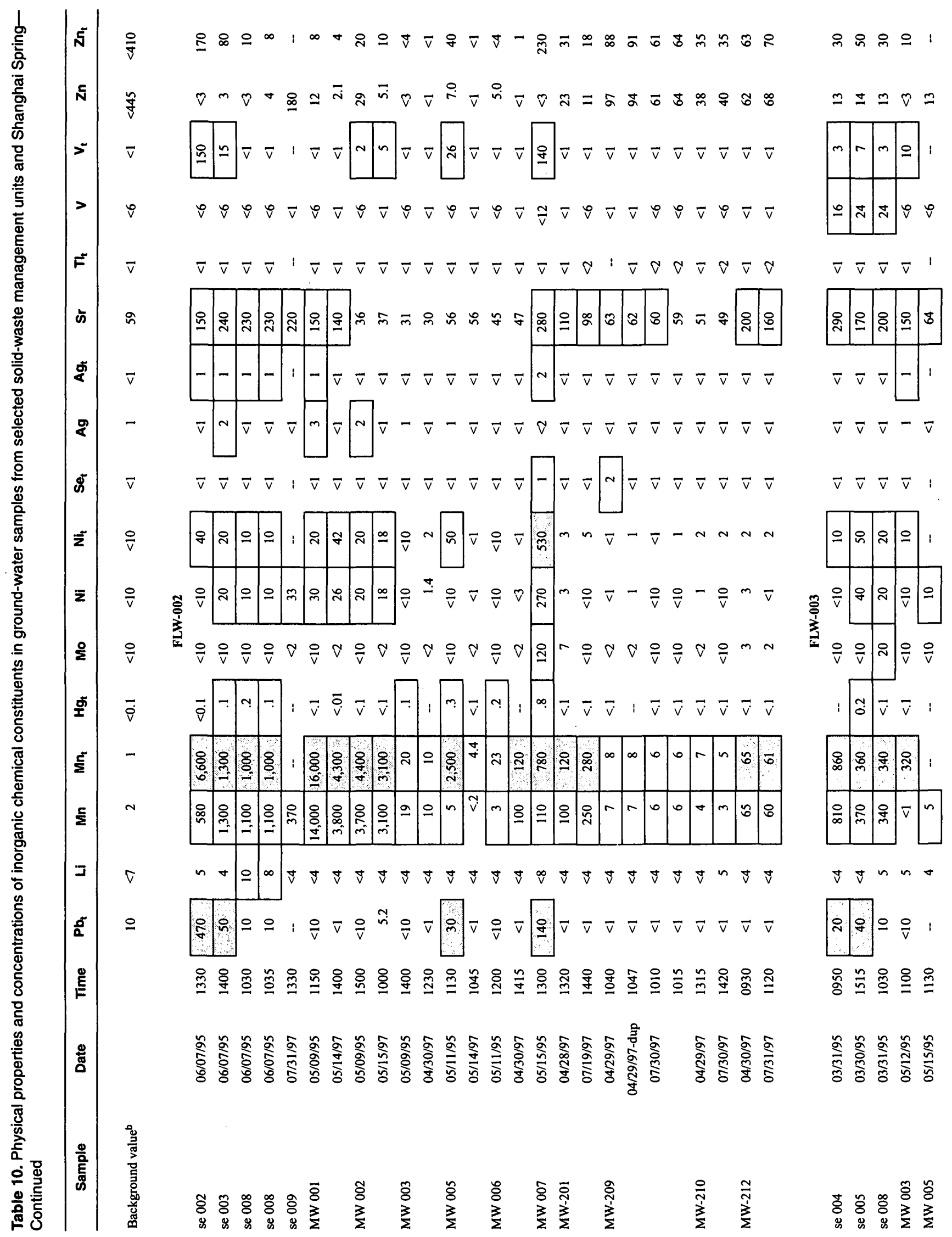




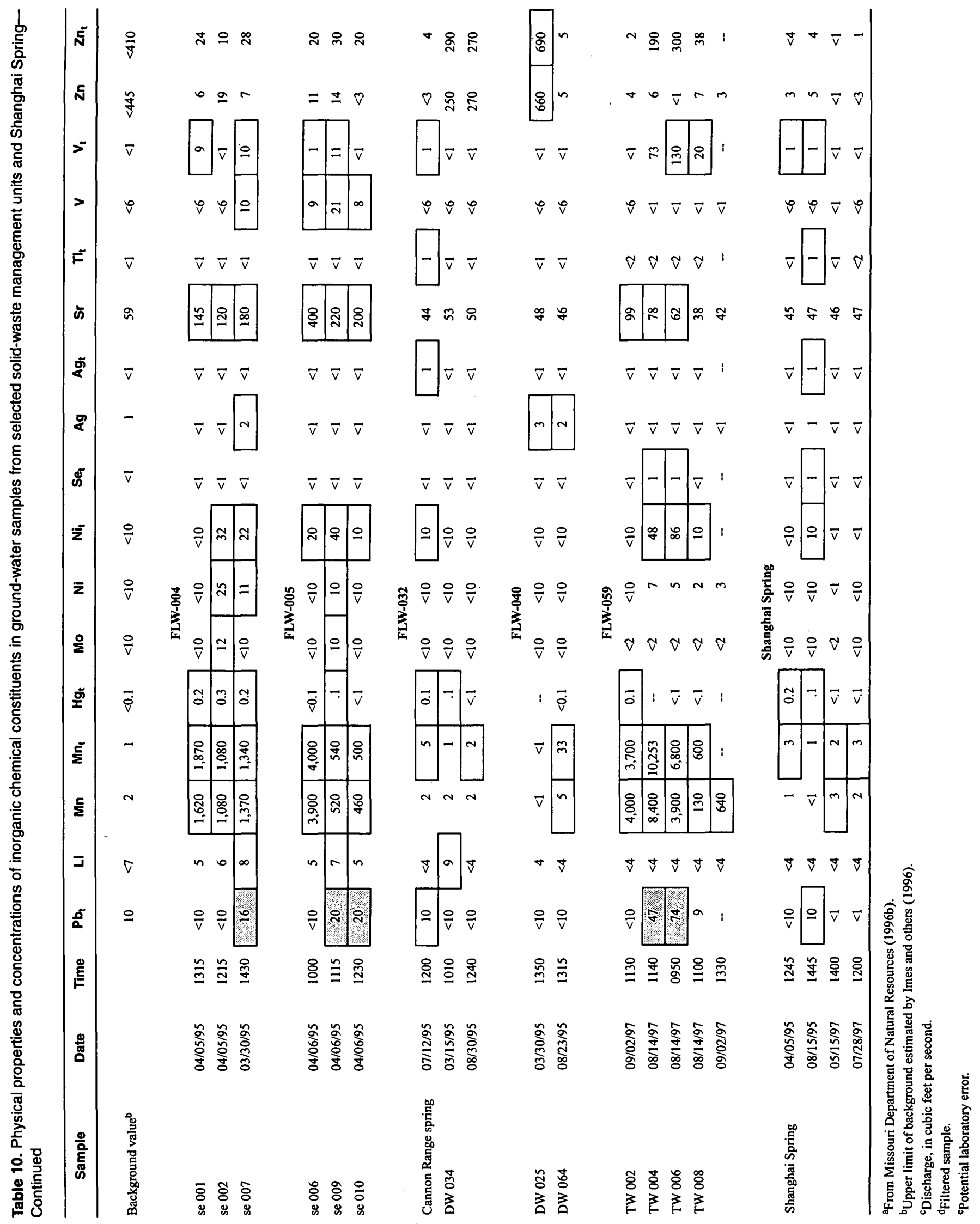




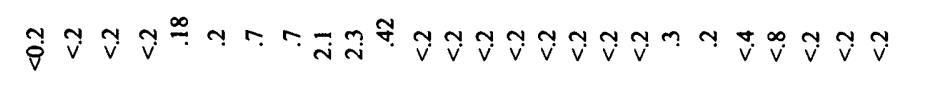

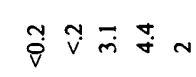

$\overrightarrow{0}-\stackrel{v}{ }$

$\stackrel{\infty}{\dot{\gamma}} \bar{i} \infty$

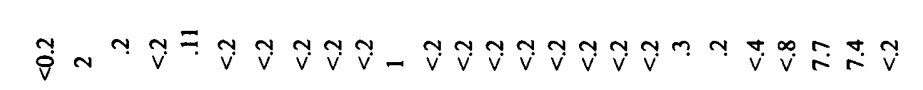

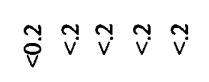

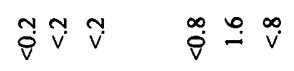

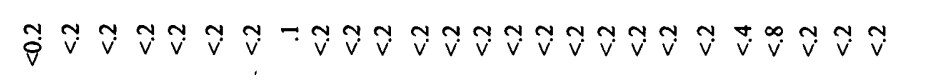

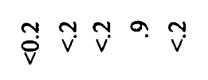

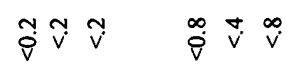

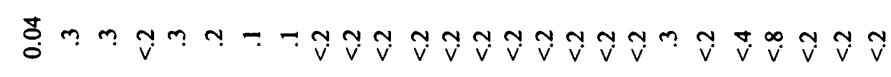

$\tilde{จ} \mathcal{\vee} \vee \mathcal{V} \mathcal{V}$

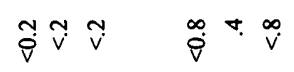

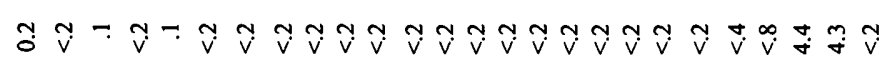

$\tilde{\vartheta} \vee \mathcal{V} \vee \mathcal{V}$

$\tilde{\nabla} \mathcal{\nabla} \sim$

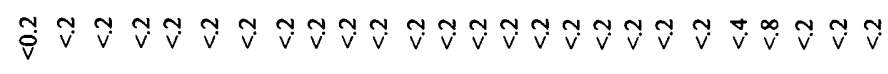

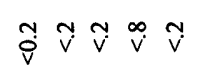

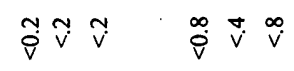

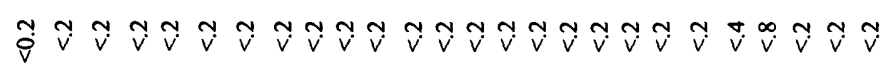

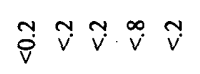

$\tilde{ช} \mathcal{ท} ท$

$\stackrel{\infty}{\dot{v}} \dot{v} \stackrel{\infty}{v}$

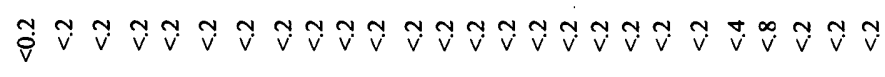

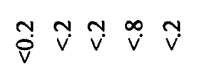

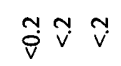

$\stackrel{\infty}{i} \dot{v} \stackrel{\infty}{v}$

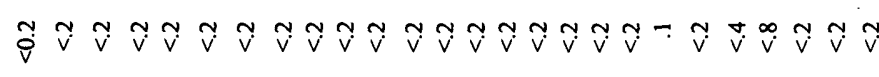

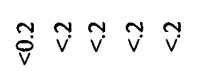

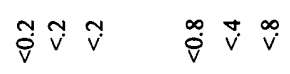

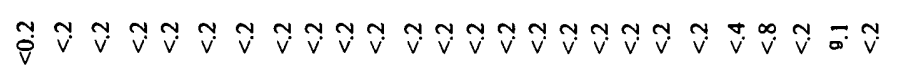

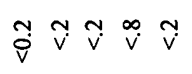

$\tilde{\vartheta} \mathcal{V} \vee$

$\stackrel{\infty}{\dot{v}} \dot{v} \stackrel{\infty}{v}$

ธิก

䒹

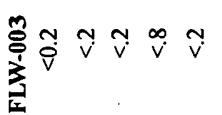

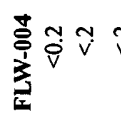

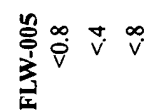

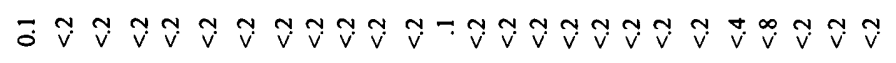

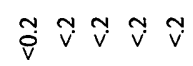

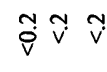

$\stackrel{\infty}{\dot{v}} \dot{v} \stackrel{\infty}{v}$

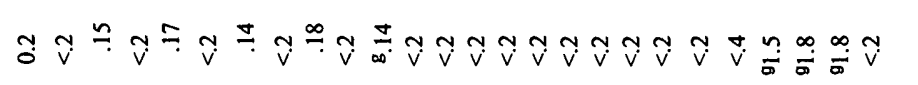

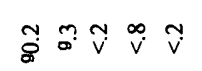

$\tilde{\vartheta}^{\top} \cdot$

$\stackrel{\infty}{\dot{v}} \stackrel{+}{\sim} \vee$

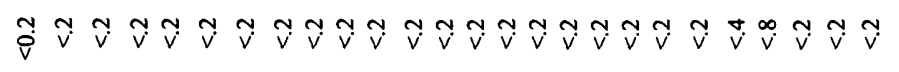

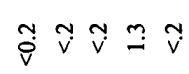

ชี่ง ที่

$\stackrel{n}{a} \underset{v}{ }$

; : : :

$1: 20=$

$i \stackrel{n}{m}$

$\tilde{b}$

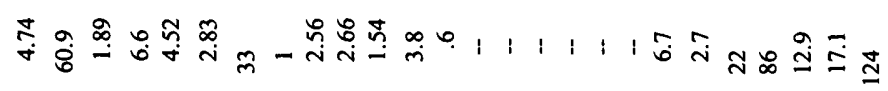

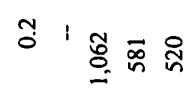

$\infty \stackrel{\circ}{\text { ஸे }}$

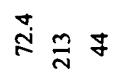

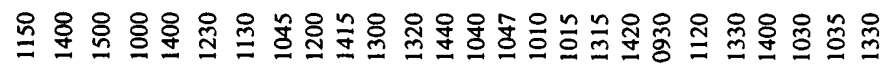

읔융용 음

$\stackrel{n}{m} \stackrel{n}{\Xi}$

䒠邑

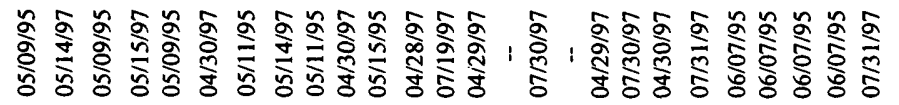

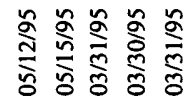

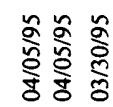

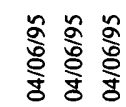




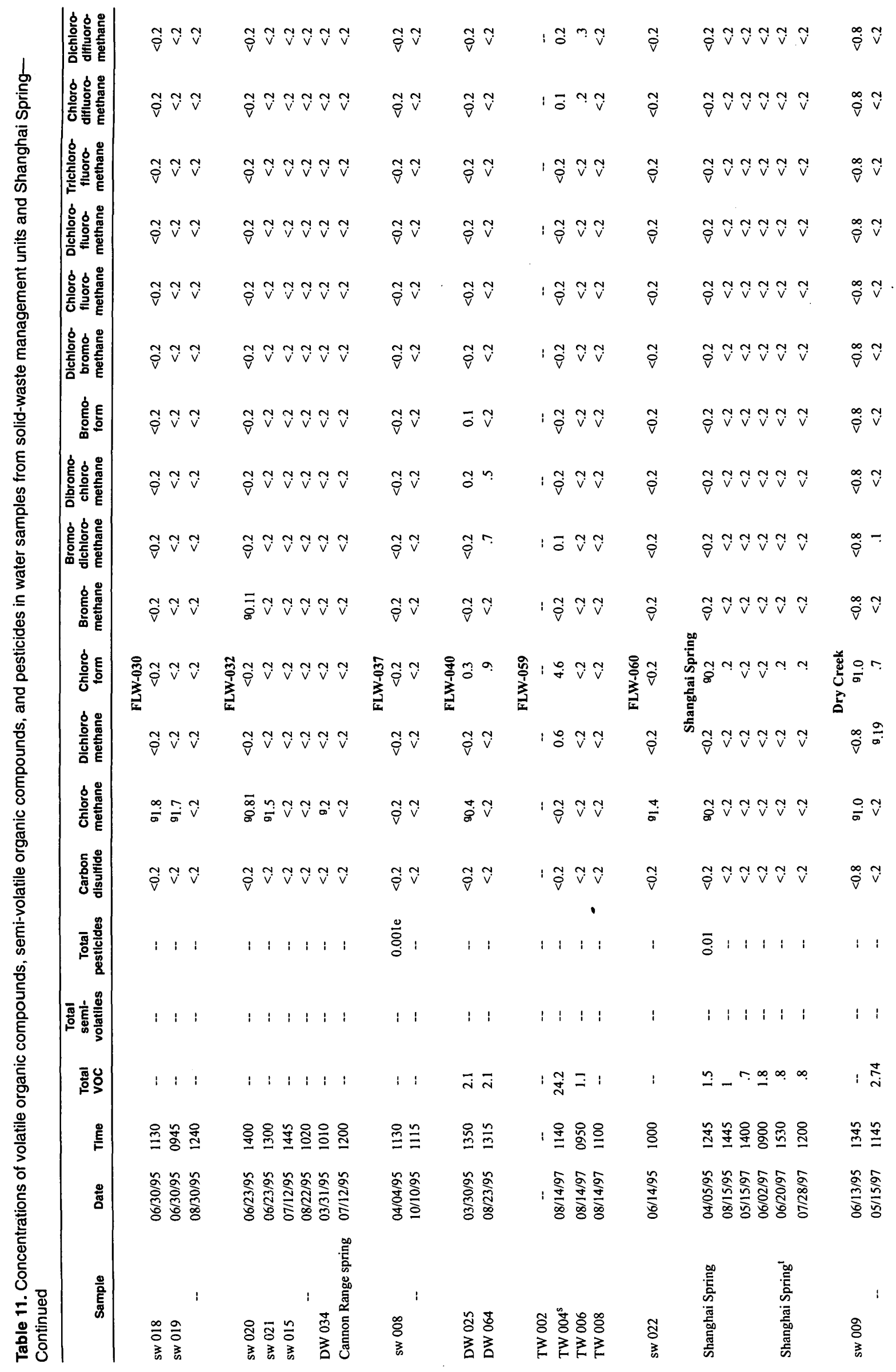

124 Geohydrology and Water Quality at the Fort Leonard Wood Military Reservation, Missouri, 1995-98 


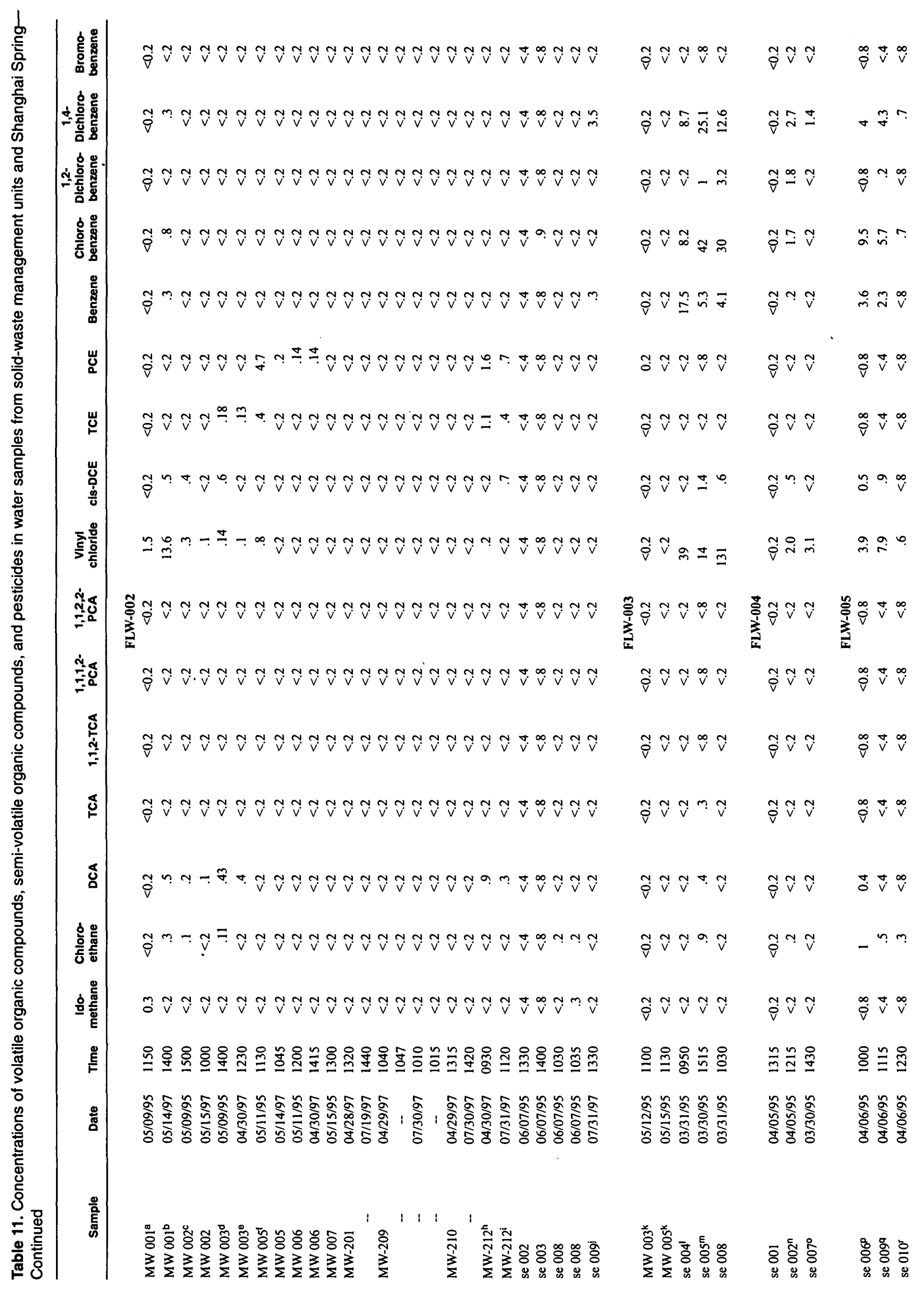




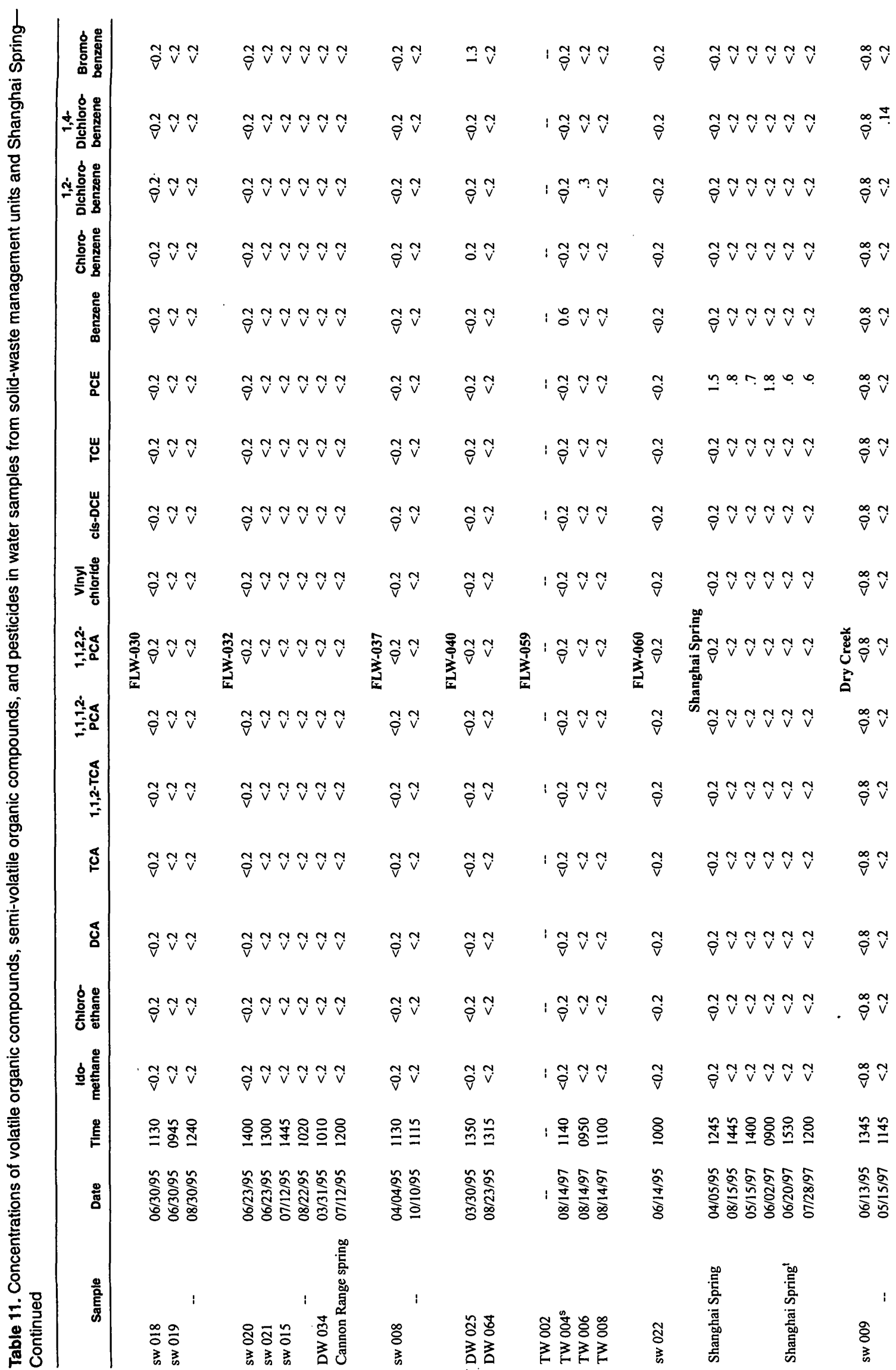




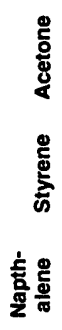

䔡

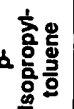

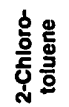

Е్

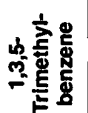

离蜜要

我离总高

离离

窟总

言竞紫

흐ㅇㅝㅗㄹ

產密

总

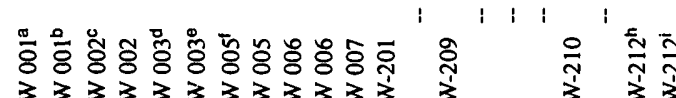

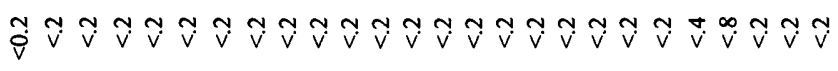

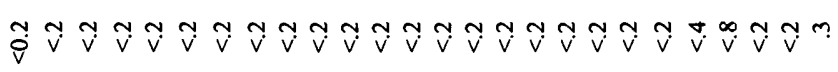

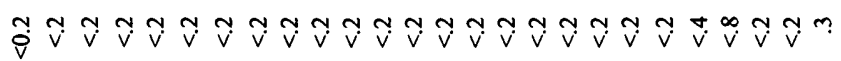

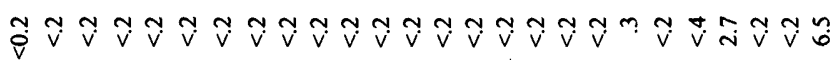

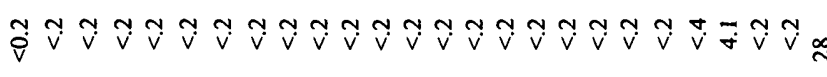

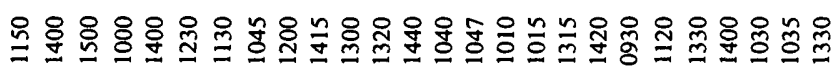

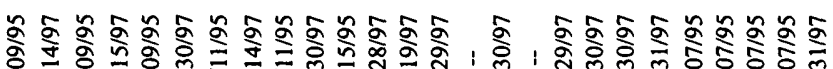

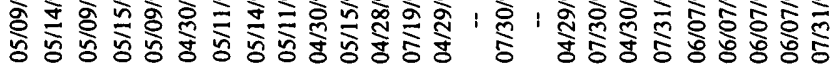

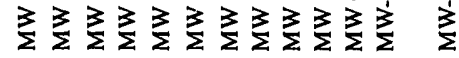

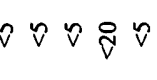

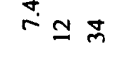

$\check{\sim} \check{v}$

จ

$\tilde{\vartheta} \mathcal{\nabla} \mathcal{V}$

$\stackrel{\infty}{v}^{\infty} \cdot \stackrel{\infty}{v}$

ขิ

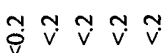

$\tilde{ช} \approx จ$

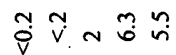

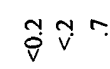

$2 \operatorname{s}^{m}$

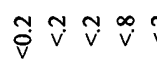

$\tilde{\vartheta} \mathcal{V} \mathcal{V}$

$\stackrel{\infty}{i} m \stackrel{\infty}{v}$

$\tilde{ช} ท ี$

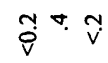

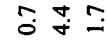

ชิำำ

$\operatorname{s}^{2}$

$\stackrel{9}{9}$

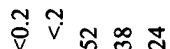

ชี่ำำ

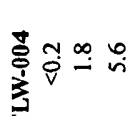

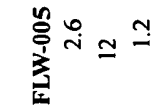

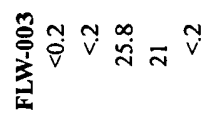

ชิำบำำ

จ $ข \sim$

$\stackrel{a}{0} \cdot \stackrel{\infty}{v}$

$\tilde{\mathcal{V}} \mathcal{\vee} \mathcal{} \sim$

$\tilde{\mathcal{v}} \sim \mathcal{v}$

$\stackrel{\infty}{\vee}+\infty$

กี จิจ

กิต ตุ

$\stackrel{\infty}{i}: n$

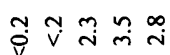

กุบข จ

కాํำ

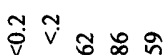

芛获安

जิ

ชิ

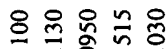

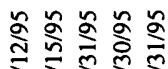

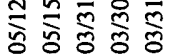

ํํํㅇำ

용

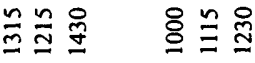

\%ั

ㅇㅎㅇ

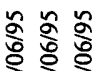

훙훙항 


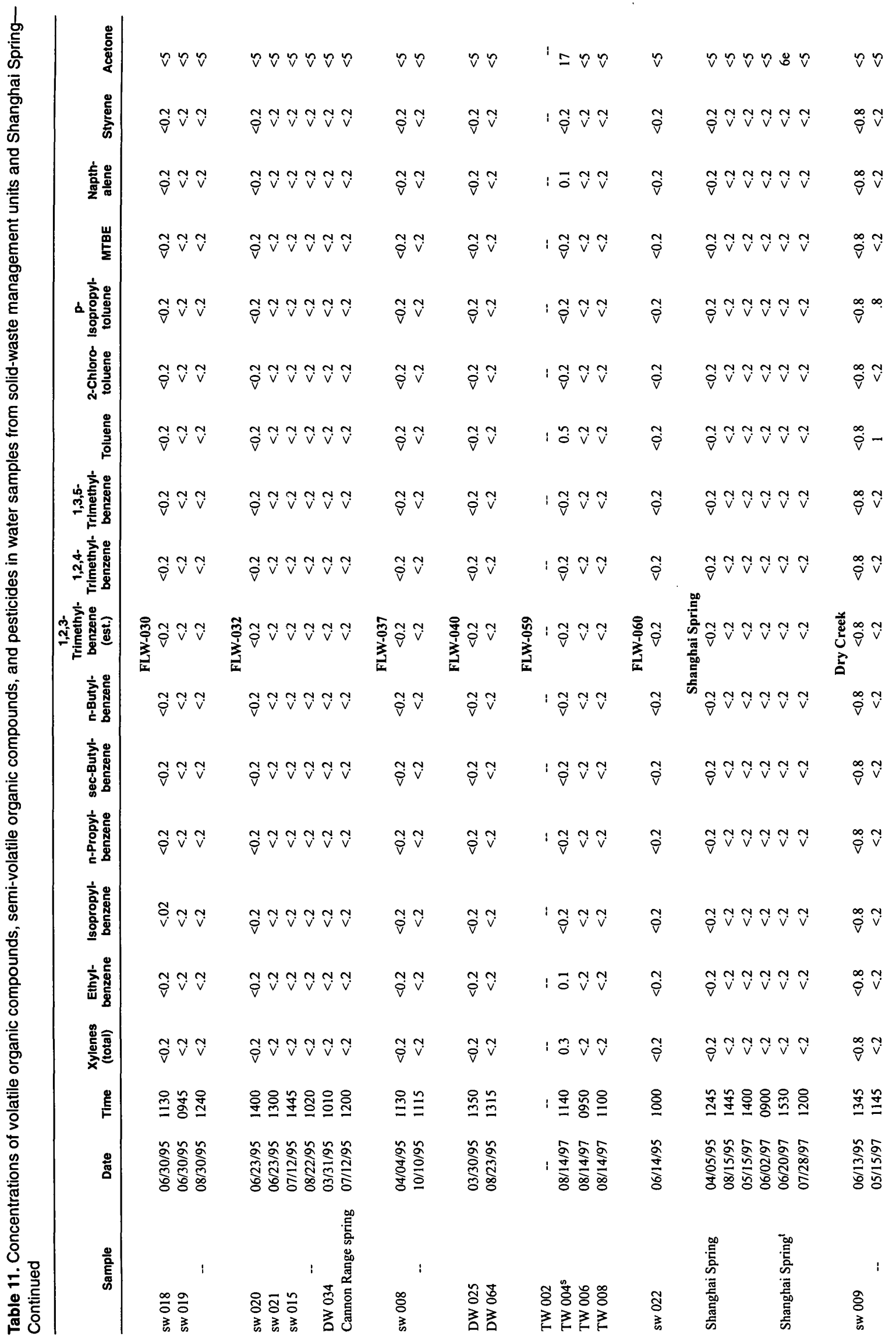




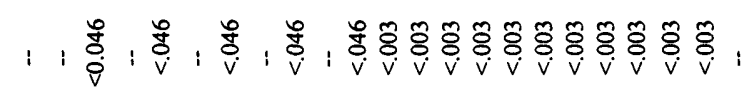

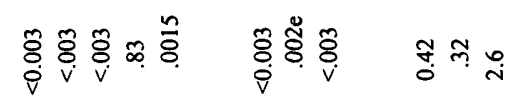

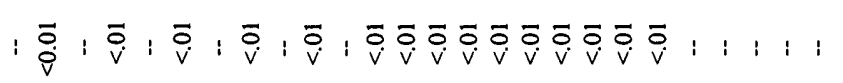

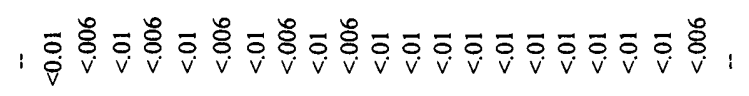

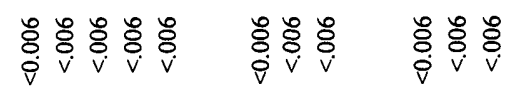

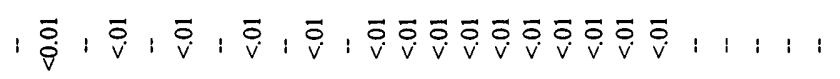

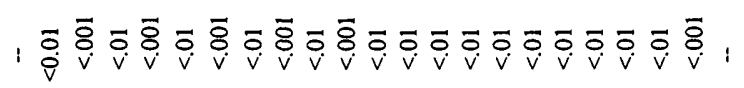

i : :

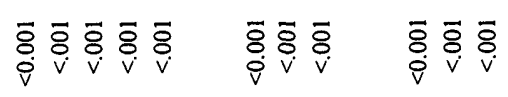

$\mid \vec{\rho}: \vec{v}: \vec{v}: \vec{v}: \vec{v}: \vec{v} \vec{v} \vec{v} \bar{v} \vec{v} \bar{v} \vec{v} \vec{v} \vec{v} \vec{v}: 1:$ :

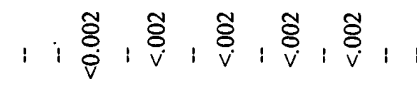

ठิ

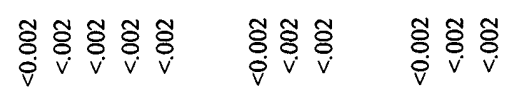

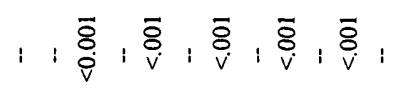

$\overrightarrow{8}: 1:$ :

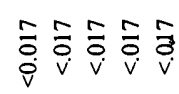

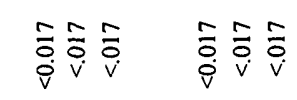

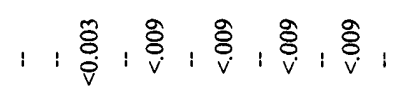

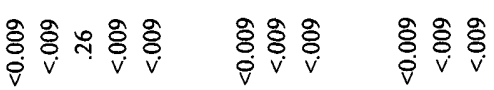
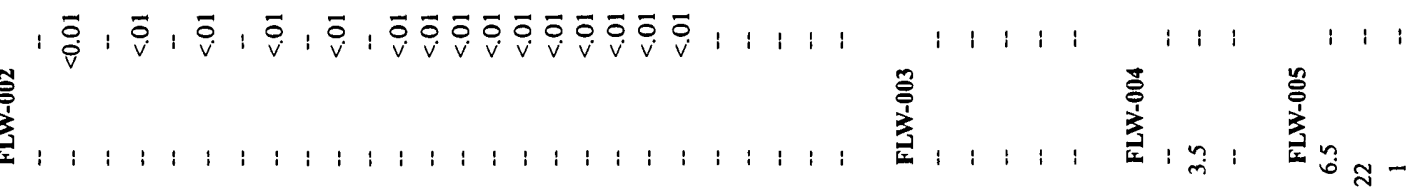

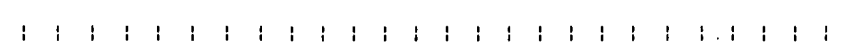

$\operatorname{100} 2$

i i i

$=$

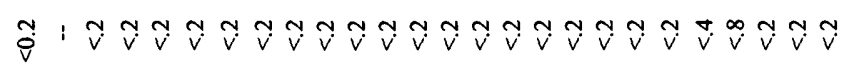

$\widetilde{\nabla} \mathcal{V} \sim \mathcal{V} \mathcal{V}$

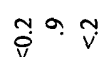

$\because$

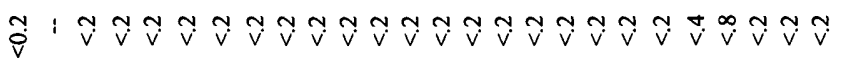

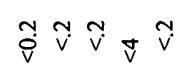

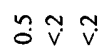

$\sim \stackrel{\nabla}{v} \stackrel{\infty}{v}$

咅紊

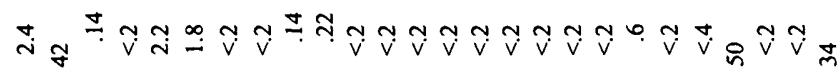

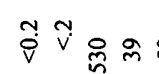

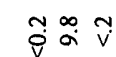

$\stackrel{\infty}{\dot{v}} \stackrel{\sim}{\sim} N$

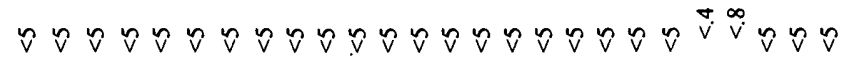

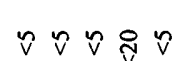

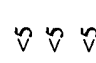

$\stackrel{\infty}{\dot{v}} \underset{v}{*} \stackrel{\infty}{v}$

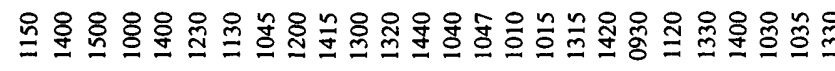

을융

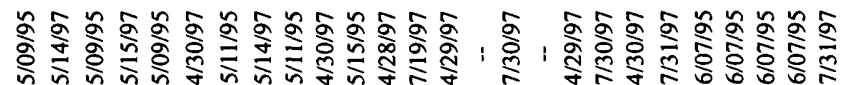

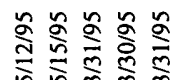

$\stackrel{\sim}{m} \frac{0}{\infty}$

昌 $\cong$

气⿳亠幺幺犬

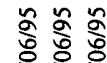

产高 


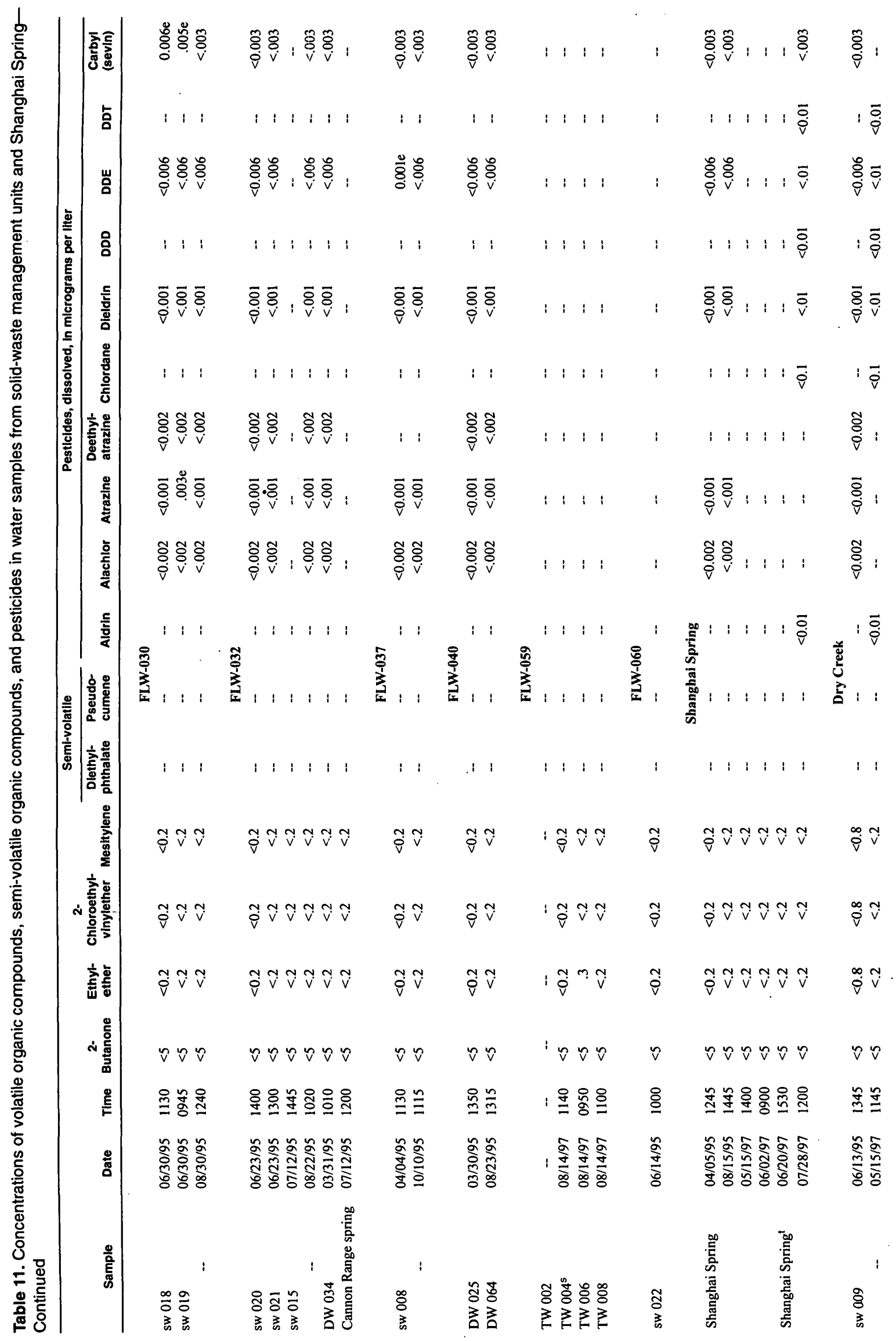




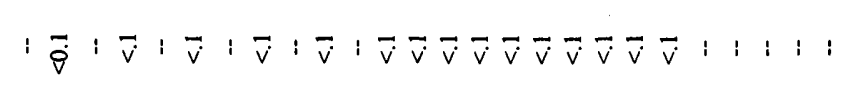

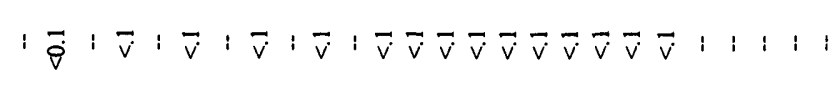

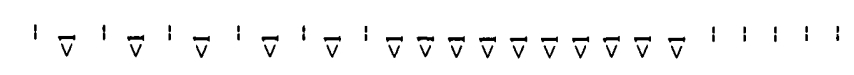

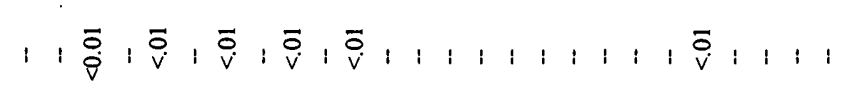

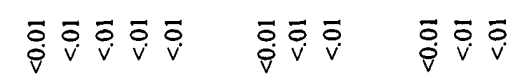

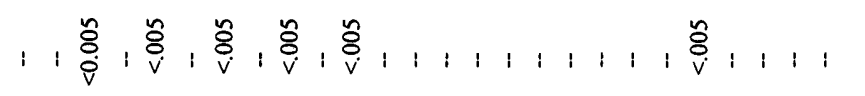

ơ

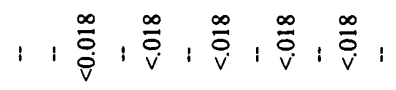

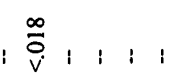

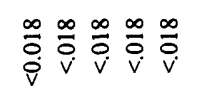

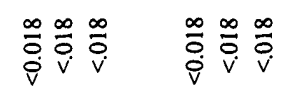

$: \vec{\rho}: \vec{v}: \vec{v}: \vec{v}: \vec{v}: \vec{v} \vec{v} \vec{v} \vec{v} \vec{v} \vec{v} \vec{v} \vec{v} \vec{v} \vec{v}: \quad 1 \quad 1: i$

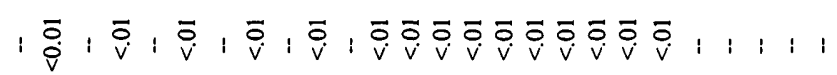

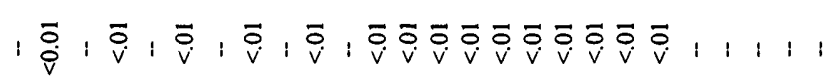

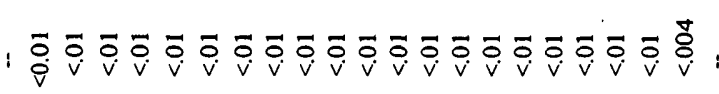

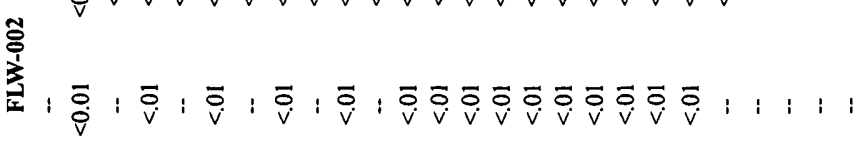

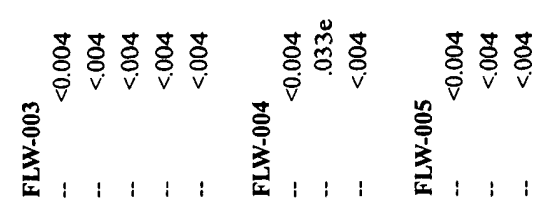

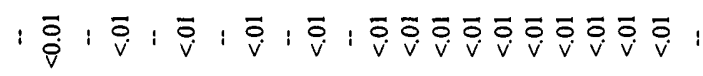

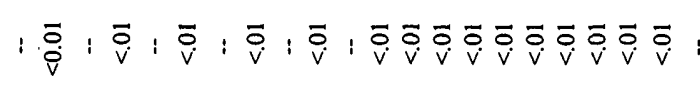

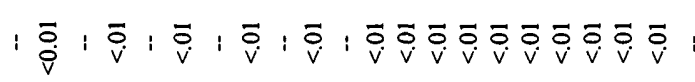

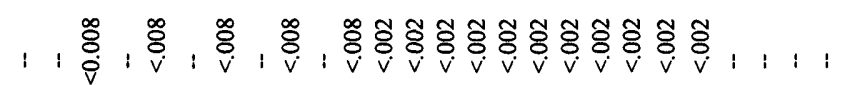

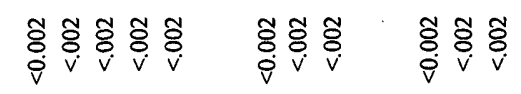

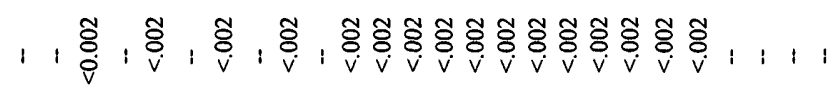

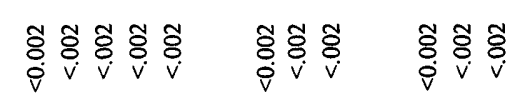

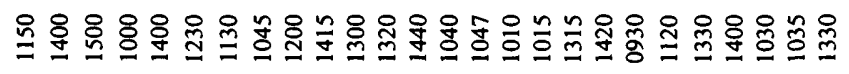

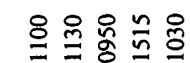

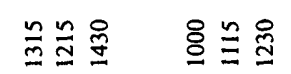

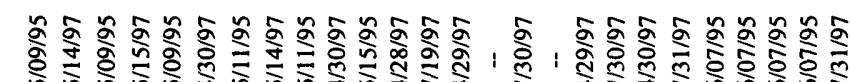

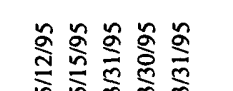

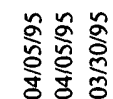

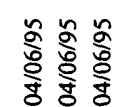




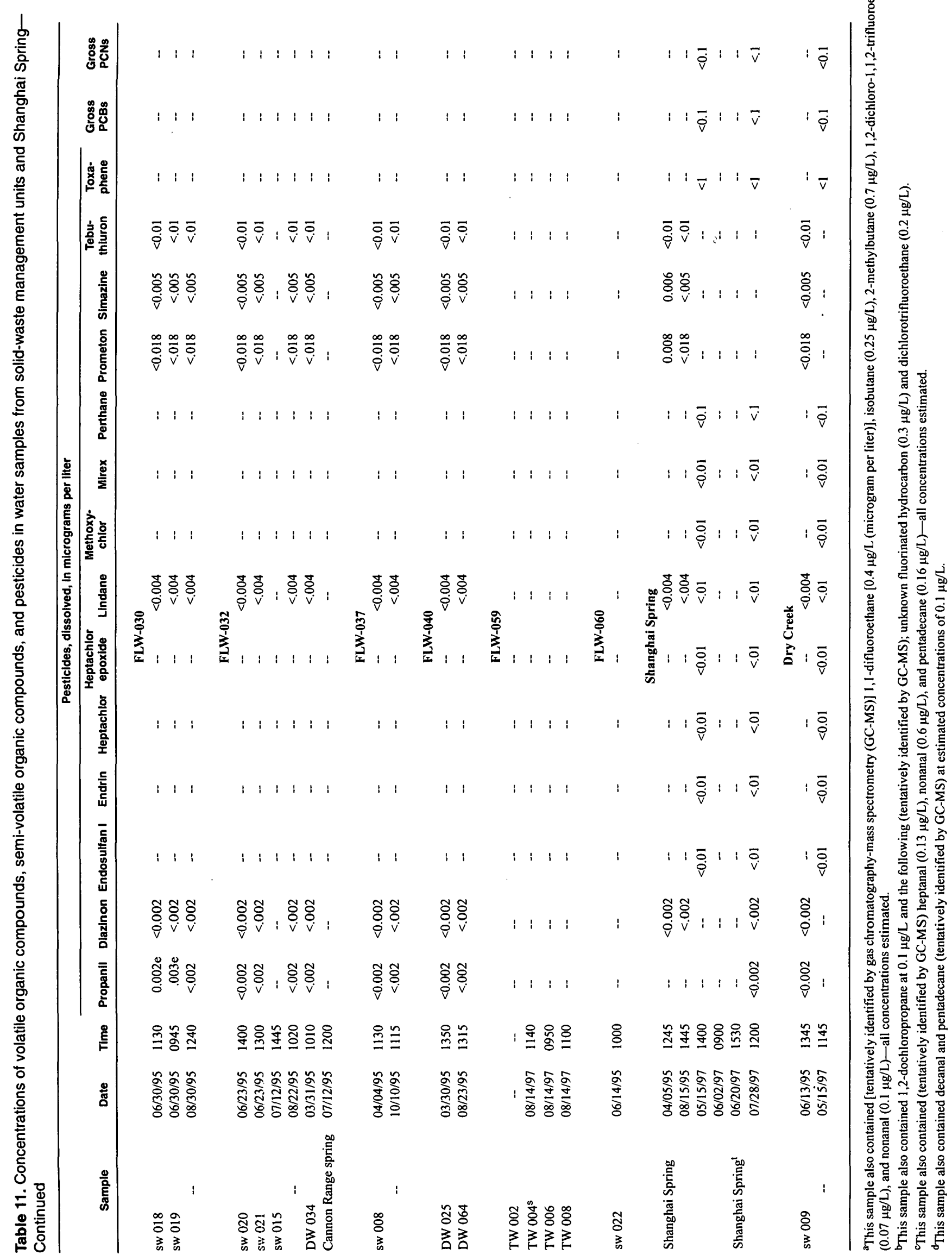




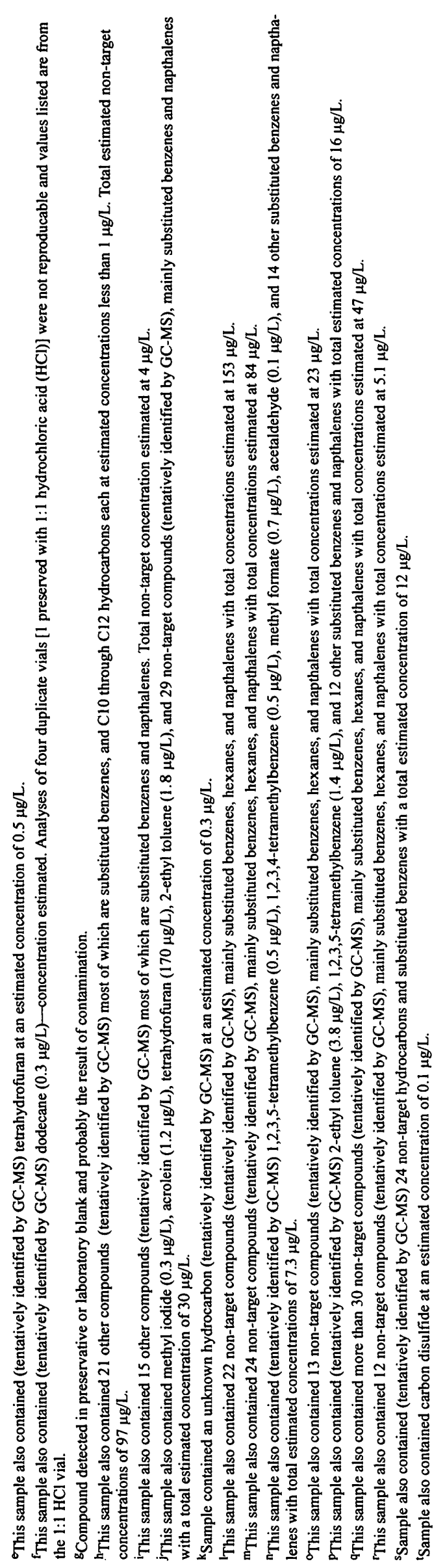




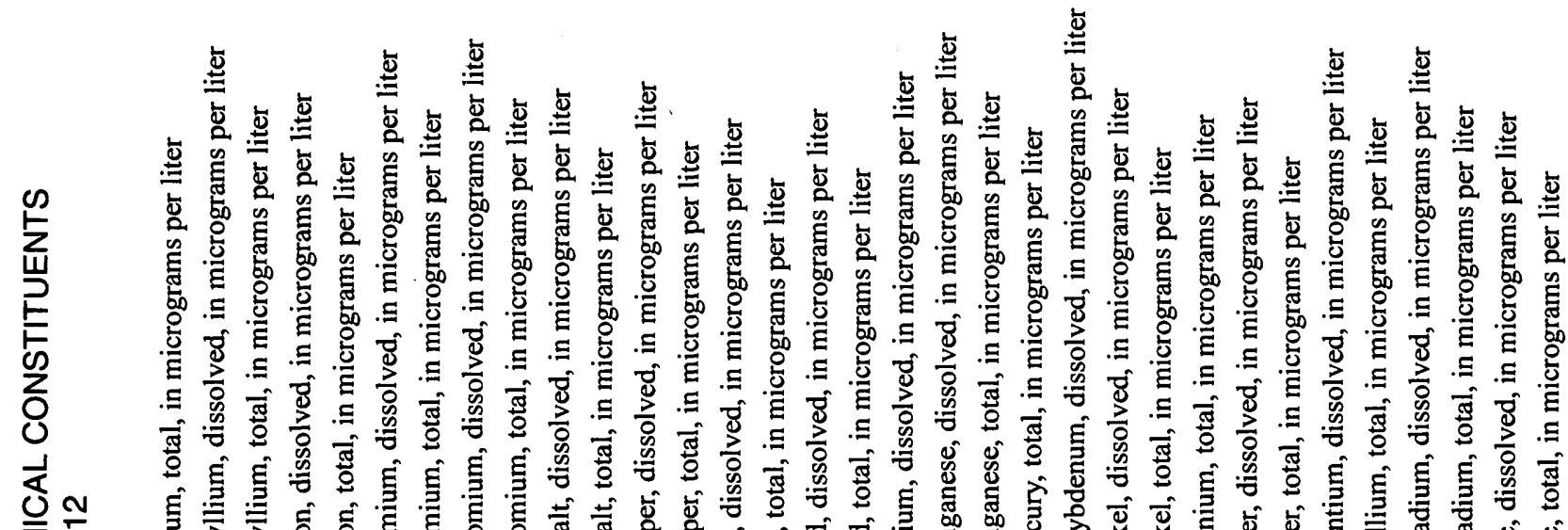

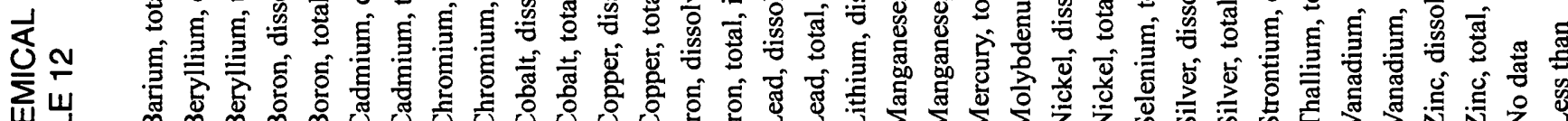

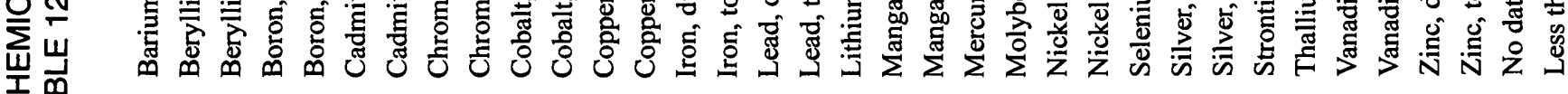

동

을

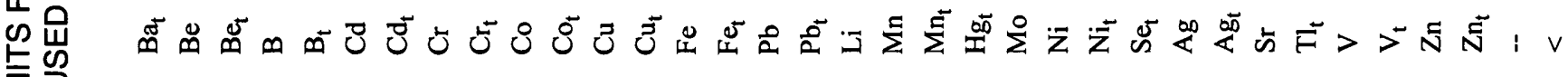

o

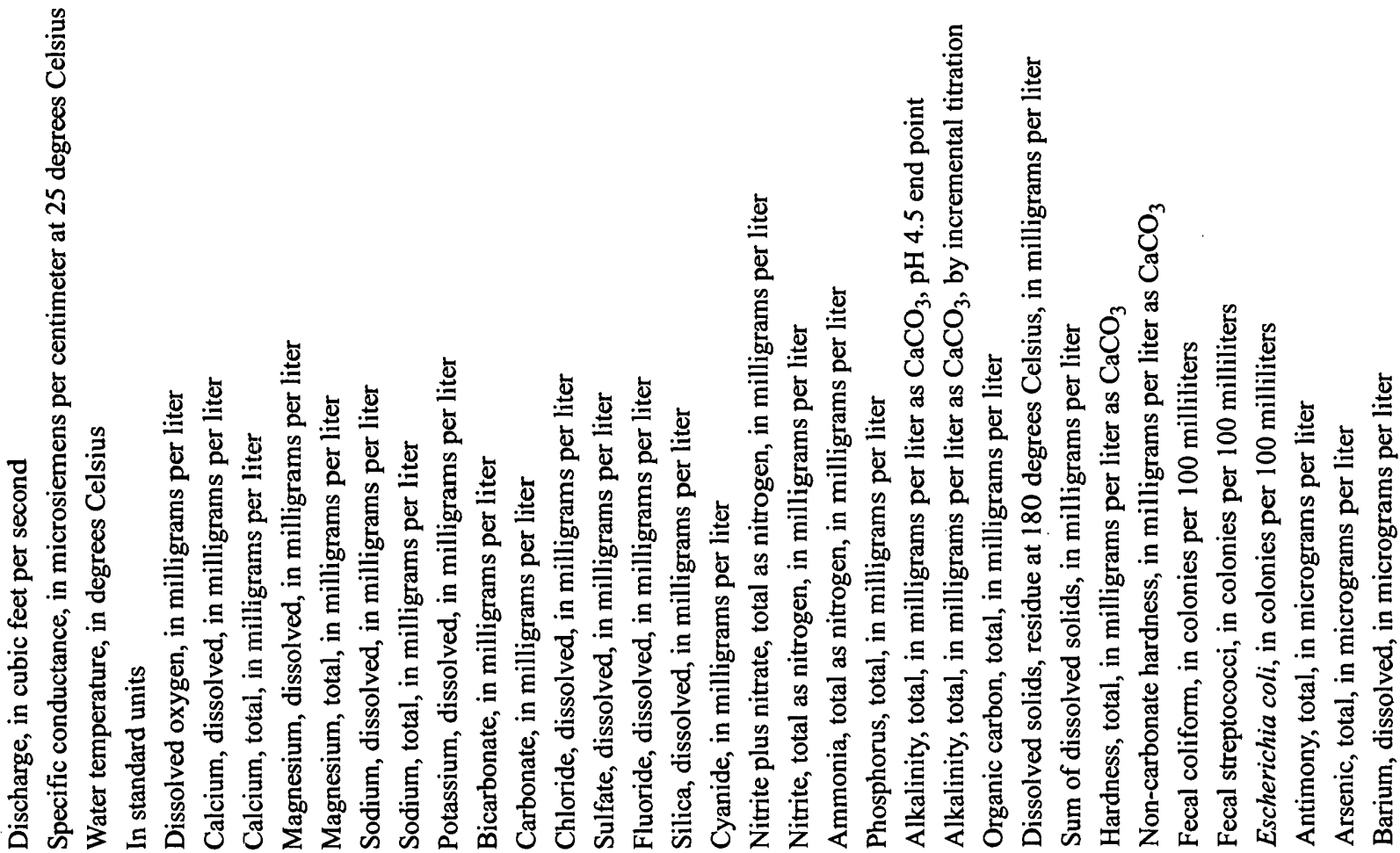

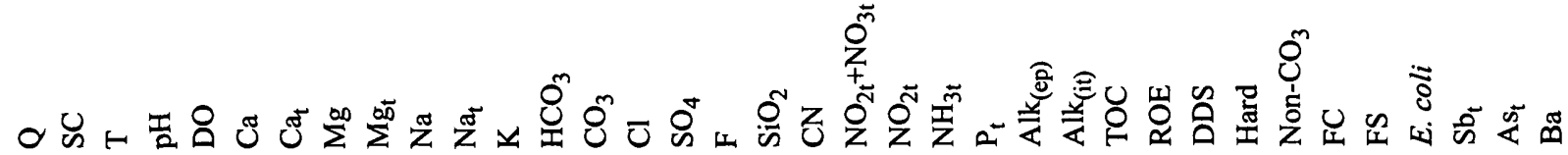




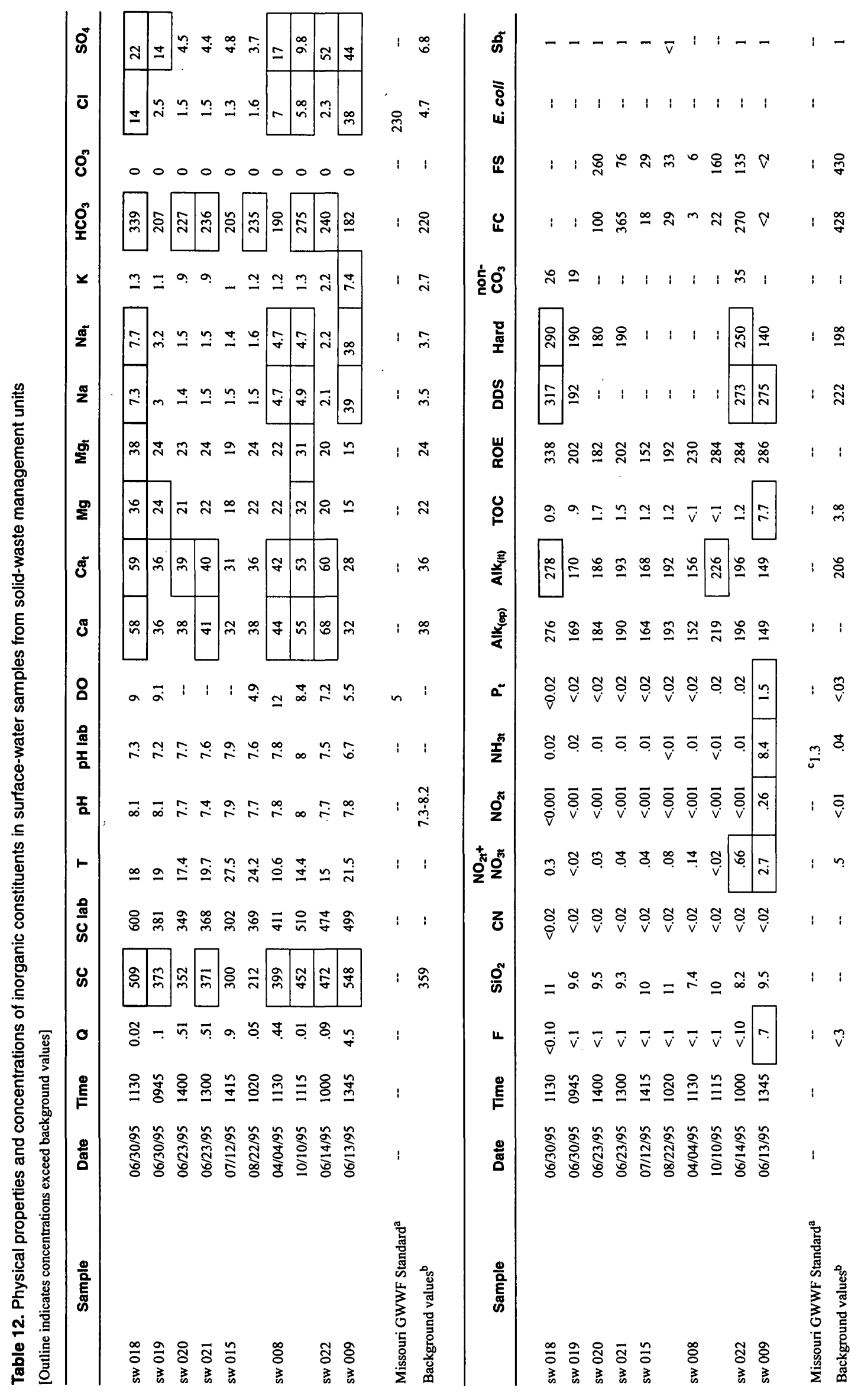




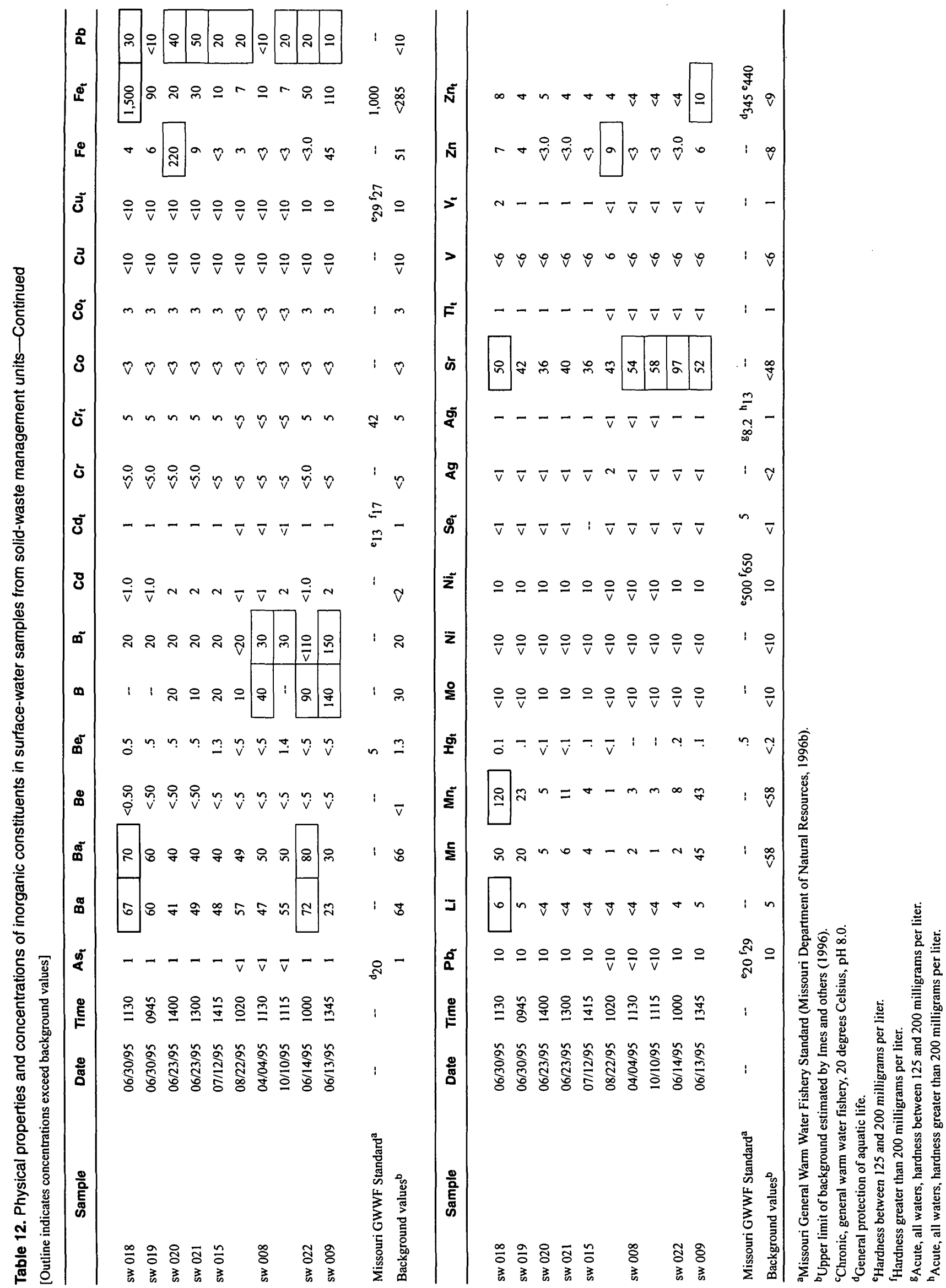




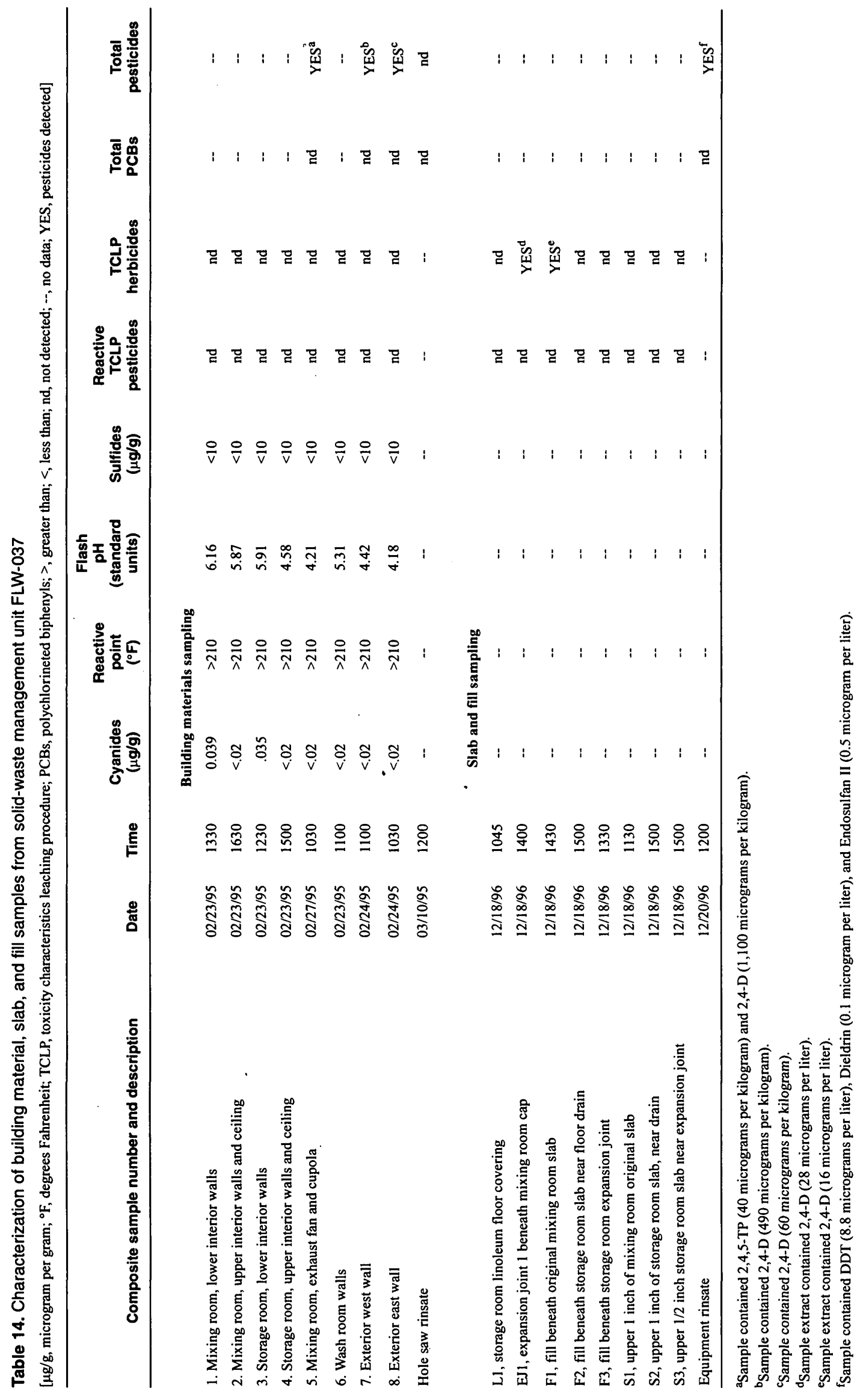




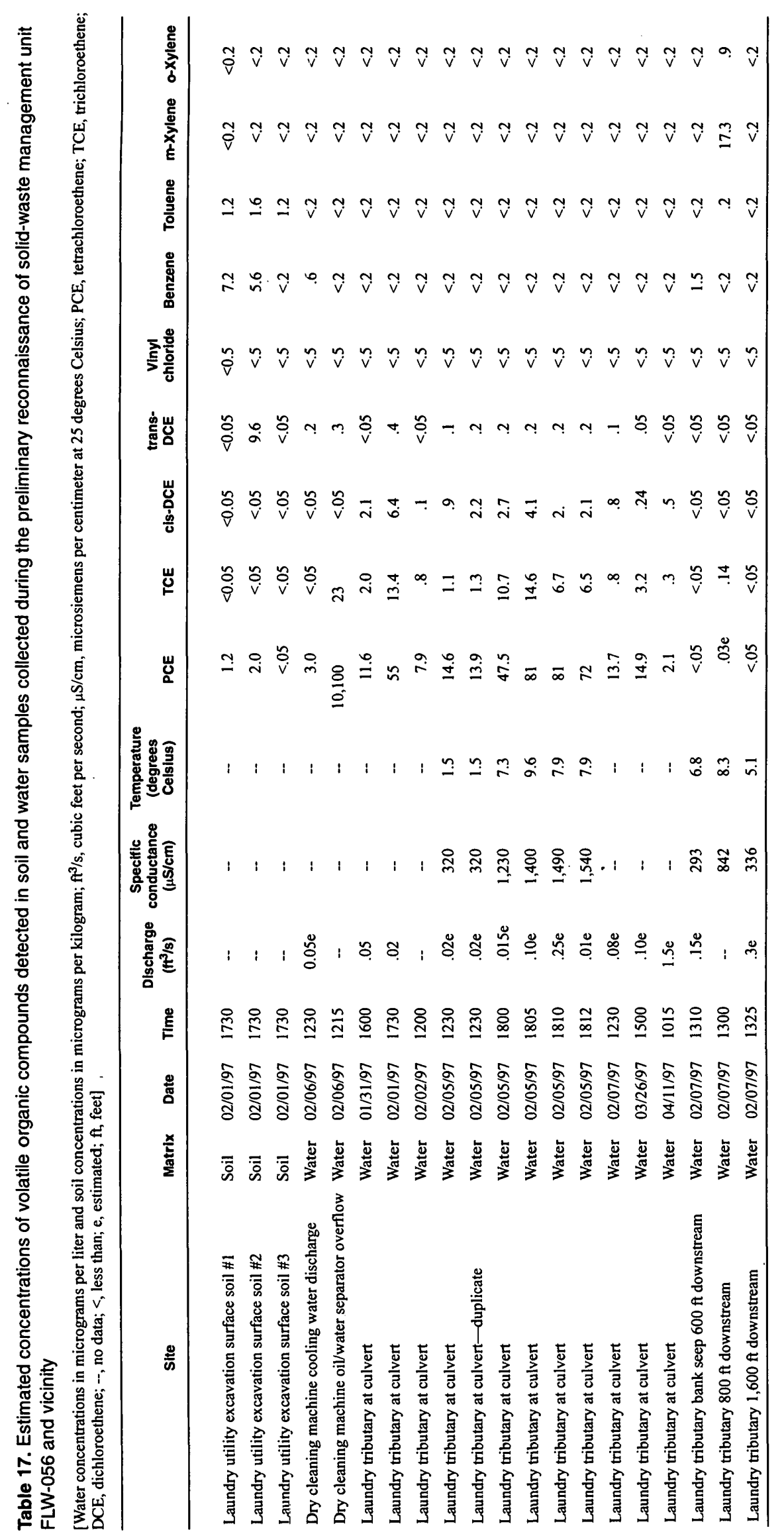


Table 19. Estimated concentrations of tetrachloroethene (PCE) and trichloroethene (TCE) in soil-gas samples from solid-waste management unit FLW-056

[All concentrations in parts per million air; $<$, less than]

\begin{tabular}{|c|c|c|c|c|}
\hline Soil-gas sampler & Date & Time & $\begin{array}{l}\text { Tetrachloroethene } \\
\text { (PCE) }\end{array}$ & $\begin{array}{l}\text { Trichloroethene } \\
\text { (TCE) }\end{array}$ \\
\hline $\mathrm{A} 2$ & $06 / 20 / 97$ & 1138 & $<0.01$ & $<0.01$ \\
\hline A4 & $06 / 20 / 97$ & 1153 & $<.01$ & $<.01$ \\
\hline B2 & $06 / 20 / 97$ & 1109 & $<.01$ & $<.01$ \\
\hline B3 & $06 / 20 / 97$ & 1118 & $<.01$ & $<.01$ \\
\hline B4 & $06 / 20 / 97$ & 1125 & $<.01$ & $<.01$ \\
\hline $\mathrm{BD}$ & $06 / 20 / 97$ & 1313 & 0 & $<.01$ \\
\hline $\mathrm{Cl}$ & $06 / 20 / 97$ & 1209 & 0 & $<.01$ \\
\hline $\mathrm{C} 2$ & $06 / 20 / 97$ & 1259 & $<.01$ & $<.01$ \\
\hline $\mathrm{C} 4$ & $06 / 20 / 97$ & 1321 & 0 & $<.01$ \\
\hline C5 & $06 / 20 / 97$ & 1330 & $<.01$ & $<.01$ \\
\hline $\mathrm{C} 6$ & 07/09/97 & 1610 & .10 & 0 \\
\hline $\mathrm{D} 1$ & $07 / 03 / 97$ & 1243 & $<.01$ & $<.01$ \\
\hline D2 & $07 / 03 / 97$ & 1300 & 20 & 0 \\
\hline D2a & $07 / 03 / 97$ & 1300 & 3.2 & $<.01$ \\
\hline $\mathrm{D} 2 \mathrm{~b}$ & $07 / 03 / 97$ & 1320 & .4 & $<.01$ \\
\hline D3 & $07 / 03 / 97$ & 1332 & $<.01$ & $<.01$ \\
\hline D4 & $07 / 03 / 97$ & 1342 & 0 & $<.01$ \\
\hline E1 & $07 / 03 / 97$ & 1354 & $<.01$ & $<.01$ \\
\hline E2 & $07 / 03 / 97$ & 1402 & 0 & $<.01$ \\
\hline E3 & $07 / 03 / 97$ & 1410 & $<.01$ & $<.01$ \\
\hline E4 & $07 / 03 / 97$ & 1418 & $<.01$ & $<.01$ \\
\hline E5 & $07 / 03 / 97$ & 1545 & ${ }^{2} 25.2$ & $\mathrm{a}_{4} .9$ \\
\hline $\mathbf{F} 1$ & $07 / 03 / 97$ & 1427 & $<.01$ & $<.01$ \\
\hline F2 & $07 / 03 / 97$ & 1434 & .30 & 0 \\
\hline F3 & $07 / 03 / 97$ & 1442 & .10 & 0 \\
\hline G1 & $07 / 03 / 97$ & 1451 & $<.01$ & $<.01$ \\
\hline G2 & $07 / 03 / 97$ & 1459 & $<.01$ & $<.01$ \\
\hline SD1 & $07 / 03 / 97$ & 1524 & $<.01$ & $<.01$ \\
\hline SD3 & $07 / 03 / 97$ & 1516 & $<.01$ & $<.01$ \\
\hline
\end{tabular}

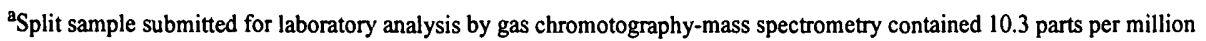
tetrachloroethene, 1.4 parts per million trichloroethene, 1 part per million cis-1,2-Dichloroethene, and 0.02 part per million vinyl chloride. 
. 
APPENDIX 

Table A1. Summary for injection site and attempted recovery sites during dye-trace test T103-08

\begin{tabular}{llll}
\hline Tracer injection date: & $\mathbf{1 2 / 0 8 / 9 5}$ & $\begin{array}{l}\text { Tracer Test No: } \\
\text { Project No: }\end{array}$ & $\begin{array}{l}\text { T103-08 } \\
\text { MO-10300 }\end{array}$ \\
\hline & & Injection Site & \\
& & & \\
Site name: & Sinkhole by road FLW 20 & Latitude: & 374347 \\
County: & Pulaski & Longitude: & 0921055 \\
Quadrangle: & Bloodland & Land net: & sec. 30, T. 35 N, R. 11 W \\
Altitude: & $1,045 \pm 10$ feet & Quarter section: & NE 1/4 SW 1/4 SE 1/4; DCA
\end{tabular}

Site description: $\quad$ Broad shallow sinkhole along east side of road FLW 20.

Field conditions: $\quad$ Cold; snow falling.

Hydrologic conditions: _ _ _ _ low flow; __ high flow; __ high-base flow; __ low-base flow; __ flood flow

$\begin{array}{llll}\text { Tracing agent: } & \text { Rhodamine WT } & \text { Pre-injection flush: } 1,000 \text { gallons } \\ \text { Agent quantity: } & 3.5 \text { to } 4.0 \text { liters } & \text { Post-injection flush: } 1,000 \text { gallons } \\ \text { Time: } & 10: 15 \text { a.m. } & \text { Investigator(s): } & \text { Brenden }\end{array}$

Remarks: Sinkhole bottom slopes from north to southwest and has small opening under tree at southwest edge. Pre-injection flush began at 9:50 a.m. The first 750 gallons of water drained quickly, but water began to pool afterwards. Pre-injection flush was stopped at 10:00 a.m., and dye was added to the draining water pooled in the injection hole. The post-injection flush was started at 10:40 a.m. Water pooled once again, but was draining slowly. Post-injection flush ended at 10:55 a.m.

Attempted Recovery Sites

\begin{tabular}{|c|c|c|c|c|c|}
\hline No. & Site name & $\begin{array}{l}\text { Latitude-longitude } \\
\text { (degrees minutes seconds) }\end{array}$ & $\begin{array}{l}\text { Sample } \\
\text { method }\end{array}$ & $\begin{array}{l}\text { Distance } \\
\text { (miles) }\end{array}$ & $\begin{array}{c}\text { Test } \\
\text { results }^{a}\end{array}$ \\
\hline 1 & Roubidoux Spring & $374931-0921205$ & Charcoal & 6.67 & $\mathrm{n}$ \\
\hline 2 & Roubidoux Creek near Ballard Hollow & $374644-0921007$ & Charcoal & 3.65 & $\mathrm{n}$ \\
\hline 3 & Ballard Hollow Stream near Laughlin Cemetery & $374636-0920948$ & Charcoal & 3.41 & $\mathrm{n}$ \\
\hline 4 & Miller Spring & $374204-0920414$ & Charcoal & 6.37 & $\mathrm{n}$ \\
\hline 5 & Road FLW 32 tributary & $374347-0920517$ & Charcoal & 3.53 & $\mathrm{n}$ \\
\hline 6 & Unnamed spring north of pumping station & $374416-0920451$ & Charcoal & 5.51 & $\mathrm{n}$ \\
\hline 7 & Stone Mill Spring & $374424-0920229$ & Charcoal & 7.73 & $\mathrm{n}$ \\
\hline 8 & Shanghai Spring & $374951-0920515$ & Charcoal & 8.63 & $\mathrm{n}$ \\
\hline
\end{tabular}

an, no dye detected. 
Table A2. Summary for injection site and attempted recovery sites during dye-trace test T103-09

\begin{tabular}{llll}
\hline Tracer injection date: & $01 / 18 / 96$ & Tracer Test No: & T103-09 \\
& & Project No: & MO-10300
\end{tabular}

\section{Injection Site}

$\begin{array}{llll}\text { Site name: } & \text { Sinkhole \#19960116-12 } & \text { Latitude: } & 374240 \\ \text { County: } & \text { Pulaski } & \text { Longitude: } & 0920851 \\ \text { Quadrangle: } & \text { Bloodland } & \text { Land net: } & \text { sec. 33, T. 35 N, R. 11 W } \\ \text { Altitude: } & 1,090 \pm 20 \text { feet } & \text { Quarter section: } & \text { NE 1/4 SE 1/4 SE 1/4; DDA }\end{array}$

Site description:

Field conditions: Hydrologic conditions:

Tracing agent:

Agent quantity:

Time:
Quarter section:

Sinkhole about 30 feet deep by 100 feet in diameter. Small opening in northeast corner of sinkhole bottom.

Cold with rain and freezing rain falling the night before injection. _.

$\begin{array}{lll}\text { Fluorescein dye } & \text { Pre-injection flush: } & \text { Rain runoff } \\ \text { 2.5 pounds } & \text { Post-injection flush: } & \text { Rain runoff } \\ \text { 9:30 a.m. } & \text { Investigator(s): } & \text { Brenden }\end{array}$

Remarks: The sinkhole is located in the firing fan of Range 5 southeast of the intersection of roads FLW 1 and FLW 30 . Dye was injected into runoff flowing into opening in bottom of sinkhole.

Attempted Recovery Sites

\begin{tabular}{|c|c|c|c|c|c|}
\hline No. & Site name & $\begin{array}{l}\text { Latitude-longitude } \\
\text { (degrees minutes seconds) }\end{array}$ & $\begin{array}{l}\text { Sample } \\
\text { method }\end{array}$ & $\begin{array}{l}\text { Distance } \\
\text { (miles) }\end{array}$ & $\begin{array}{c}\text { Test } \\
\text { results }\end{array}$ \\
\hline 1 & Roubidoux Spring & $374931-0921205$ & Charcoal & 8.39 & $\mathrm{n}$ \\
\hline 2 & Tunnel Hollow Spring & $374745-0920926$ & Charcoal & 5.86 & $\mathrm{n}$ \\
\hline 3 & Ballard Hollow Stream near Laughlin Cemetery & $374636-0920948$ & Charcoal & 4.61 & $\mathrm{n}$ \\
\hline 4 & Roubidoux Creek site \#2 & $374644-0921007$ & Charcoal & 4.82 & $\mathrm{n}$ \\
\hline 5 & Miller Spring & $374204-0920414$ & Charcoal & 4.25 & $\mathbf{p}$ \\
\hline 6 & FLW-32 unnamed spring & $374359-0920542$ & Charcoal & 3.26 & $\mathrm{n}$ \\
\hline 7 & Sandstone Spring & $374416-0920451$ & Charcoal & 4.10 & $\mathrm{n}$ \\
\hline 8 & Stone Mill Spring & $374424-0920229$ & Charcoal & 6.17 & $\mathrm{n}$ \\
\hline 9 & Shanghai Spring & $374951-0920515$ & Charcoal & 8.84 & $\mathrm{n}$ \\
\hline 10 & Big Piney River & $374533-0920326$ & Charcoal & 5.96 & $\mathrm{n}$ \\
\hline
\end{tabular}

ap, positive dye detection; $n$, no dye detected. 
Table A3. Summary for successful dye recovery at Miller Spring during dye-trace test T103-09

\begin{tabular}{|c|c|c|c|}
\hline Tracer injection date: & $01 / 18 / 96$ & $\begin{array}{l}\text { Tracer Test No: } \\
\text { Project No: }\end{array}$ & $\begin{array}{l}\text { T103-09 } \\
\text { MO-10300 }\end{array}$ \\
\hline \multicolumn{4}{|c|}{ Injection Site } \\
\hline $\begin{array}{l}\text { Site name: } \\
\text { County: } \\
\text { Quadrangle: } \\
\text { Altitude: }\end{array}$ & $\begin{array}{l}\text { Sinkhole \#19960116-12 } \\
\text { Pulaski } \\
\text { Bloodland } \\
1,090 \pm 20 \text { feet }\end{array}$ & $\begin{array}{l}\text { Latitude: } \\
\text { Longitude: } \\
\text { Land net: } \\
\text { Quarter section: }\end{array}$ & $\begin{array}{l}374240 \\
0920851 \\
\text { sec. } 33, \text { T. } 35 \mathrm{~N}, \mathrm{R} .11 \mathrm{~W} \\
\text { NE } 1 / 4 \text { SE } 1 / 4 \text { SE } 1 / 4 \text {; DDA }\end{array}$ \\
\hline $\begin{array}{l}\text { Site description: } \\
\text { Field conditions: } \\
\text { Hydrologic conditions: }\end{array}$ & \multicolumn{3}{|c|}{$\begin{array}{l}\text { Large sinkhole about } 30 \text { feet deep by } 100 \text { feet in diameter. } \\
\text { Cold with rain and freezing rain the night before injection. } \\
\text { _x_low flow; __ high flow; __ high-base flow; __ low-base flow; __ flood flow }\end{array}$} \\
\hline $\begin{array}{l}\text { Tracing agent: } \\
\text { Agent quantity: } \\
\text { Time: }\end{array}$ & $\begin{array}{l}\text { Fluorescein dye } \\
2.5 \text { pounds } \\
9: 30 \text { a.m. }\end{array}$ & $\begin{array}{l}\text { Pre-injection flush: } \\
\text { Post-injection flush: } \\
\text { Investigator(s): }\end{array}$ & $\begin{array}{l}\text { Rain runoff } \\
\text { Rain runoff } \\
\text { Brenden }\end{array}$ \\
\hline
\end{tabular}

\section{Recovery Site}

$\begin{array}{llll}\begin{array}{l}\text { Site name: } \\ \text { County: }\end{array} & \text { Miller Spring } & \text { Latitude: } & 374204 \\ \text { Quadrangle: } & \text { Pulaski } & \text { Longitude: } & 0920414 \\ \text { Altitude: } & \text { Bloodland } & \text { Land net: } & \text { sec. 6, T. 34 N, R. 10 W } \\ & 800 \text { feet } \pm 20 \text { feet } & \text { Quarter section: } & \text { SW 1/4 NW 1/4 NE 1/4; ABC } \\ & & & \\ \text { Sampling method: } & \text { Charcoal packet } & \text { Trace length: } & 4.25 \text { miles } \\ \text { Analytical method: } & \text { Shimadzu RF5000u } & \text { Travel time: } & 19 \text { to 26 days }\end{array}$

File names of the sequence of traces indicating a positive dye recovery.

$\begin{array}{lll}19960116.06 & 19960122.06 & 19960130.06 \\ 19960206.06 & 19960213.06 & 19960220.06 \\ 19960226.06 & 19960304.06 & 19960311.06 \\ 19960322.06 & 19960404.06 & 19960424.06\end{array}$

Remarks: Dye cloud first appeared on charcoal packet \#19960122.06 with an intensity of 29.61 units. Packet \#19960130 had an intensity of more than 1,000 units. Dye first reached Miller Spring between January 22 and 30. 
Table A4. Summary for injection site and attempted recovery sites during dye-trace test T103-10

\begin{tabular}{|c|c|c|c|}
\hline Tracer injection date: & $02 / 13 / 96$ & $\begin{array}{l}\text { Tracer Test No: } \\
\text { Project No: }\end{array}$ & $\begin{array}{l}\text { T103-10 } \\
\text { MO-10300 }\end{array}$ \\
\hline \multicolumn{4}{|c|}{ Injection Site } \\
\hline Site name: & Dry Creek near STP & Latitude: & 374737 \\
\hline County: & Pulaski & Longitude: & 0920635 \\
\hline Quadrangle: & Devils Elbow & Land net: & sec. 2, T. $35 \mathrm{~N}, \mathrm{R} .11 \mathrm{~W}$ \\
\hline Altitude: & $880 \pm 20$ feet & Quarter section: & NE $1 / 4 \mathrm{SW} 1 / 4 \mathrm{NW} 1 / 4 ; \mathrm{BCA}$ \\
\hline Site description: & \multicolumn{3}{|c|}{$\begin{array}{l}\text { Dry Creek streambed about } 0.75 \text { mile downstream from the Fort Leonard Wood Military Reservation } \\
\text { sewage treatment plant (STP) outflow. }\end{array}$} \\
\hline $\begin{array}{l}\text { Field conditions: } \\
\text { Hydrologic conditions: }\end{array}$ & \multicolumn{3}{|c|}{$\begin{array}{l}\text { Sunny and warm. } \\
\text { _ } \_ \text {_low flow; __ high flow; __ high-base flow; __ low-base flow; __ flood flow }\end{array}$} \\
\hline Tracing agent: & Eosine OJ dye & Pre-injection flush: & Streamflow \\
\hline Agent quantity: & 0.5 pound & Post-injection flush: & Streamflow \\
\hline Time: & $2: 25$ p.m. & Investigator(s): & Brenden \\
\hline
\end{tabular}

Remarks: Injected dye 12 feet upstream from point where stream flow disappeared into Dry Creek streambed.

Attempted Recovery Sites

\begin{tabular}{|c|c|c|c|c|c|}
\hline No. & Site name & $\begin{array}{l}\text { Latitude-longitude } \\
\text { (degrees minutes seconds) }\end{array}$ & $\begin{array}{l}\text { Sample } \\
\text { method }\end{array}$ & $\begin{array}{l}\text { Distance } \\
\text { (miles) }\end{array}$ & $\begin{array}{c}\text { Test } \\
\text { results }^{a}\end{array}$ \\
\hline 1 & Roubidoux Spring & $374931-0921205$ & Charcoal & 5.44 & $\mathrm{n}$ \\
\hline 2 & Tunnel Hollow Spring & $374745-0920926$ & Charcoal & 2.56 & $\mathrm{n}$ \\
\hline 3 & Ballard Hollow Stream near Laughlin Cemetery & $374636-0920948$ & Charcoal & 3.18 & $\mathrm{n}$ \\
\hline 4 & Roubidoux Creek site \#2 & $374644-0921007$ & Charcoal & 3.37 & $\mathrm{n}$ \\
\hline 5 & Miller Spring & $374204-0920414$ & Charcoal & 4.18 & $\mathrm{n}$ \\
\hline 6 & FLW-32 unnamed spring & $374359-0920542$ & Charcoal & 4.27 & $\mathrm{n}$ \\
\hline 7 & Sandstone Spring & $374416-0920451$ & Charcoal & 4.18 & $\mathrm{n}$ \\
\hline 8 & Stone Mill Spring & $374424-0920229$ & Charcoal & 5.29 & $\mathrm{n}$ \\
\hline 9 & Shanghai Spring & $374951-0920515$ & Charcoal & 2.78 & $\mathbf{p}$ \\
\hline 10 & Dry Creek (above injection site) & $374732-0920640$ & Charcoal & .12 & $\mathrm{n}$ \\
\hline
\end{tabular}

ap, positive dye detection; $\mathbf{n}$, no dye detected. 
Table A5. Summary for successful dye recovery at Shanghai Spring during dye-trace test T103-10

\begin{tabular}{llll}
\hline Tracer injection date: & $\mathbf{0 2 / 1 3 / 9 6}$ & $\begin{array}{l}\text { Tracer Test No: } \\
\text { Project No: }\end{array}$ & $\begin{array}{l}\text { T103-10 } \\
\text { MO-10300 }\end{array}$ \\
\hline
\end{tabular}

\section{Injection Site}

$\begin{array}{llll}\text { Site name: } & \text { Dry Creek near STP } & \text { Latitude: } & 374737 \\ \text { County: } & \text { Pulaski } & \text { Longitude: } & 0920635 \\ \text { Quadrangle: } & \text { Devils Elbow } & \text { Land net: } & \text { sec. 2, T. 35 N, R. 11 W } \\ \text { Altitude: } & 880 \pm 20 \text { feet } & \text { Quarter section: } & \text { NE 1/4 SW 1/4 NW1/4; BCA }\end{array}$

Site description:

Dry Creek streambed, about 0.75 mile downstream from the Fort Leonard Wood Military Reservation sewage treatment plant (STP) outflow.

Field conditions: Sunny and warm.

Hydrologic conditions: _ _ _ $_{-}$low flow; _ _ high flow; _ _ high-base flow; __ low-base flow; _ flood flow

Tracing agent: $\quad$ Eosine OJ dye

Agent quantity: $\quad 0.5$ pound

Time:
Pre-injection flush: Streamflow
Post-injection flush: Streamflow Investigator(s): Brenden

\section{Recovery Site}

$\begin{array}{llll}\begin{array}{l}\text { Site name: } \\ \text { County: }\end{array} & \text { Shanghai Spring } & \text { Latitude: } & 374951 \\ \text { Quadrangle: } & \text { Pulaski } & \text { Longitude: } & 0920515 \\ \text { Altitude: } & \text { Devils Elbow } & \text { Land net: } & \text { sec. 24, T. 36 N, R. 11 W } \\ & 750 \text { feet } \pm 20 \text { feet } & \text { Quarter section: } & \text { NW 1/4 NE 1/4 SW 1/4; CAB } \\ \text { Sampling method: } & \text { Charcoal packet } & & \\ \text { Analytical method: } & \text { Shimadzu RF5000u } & \text { Trace length: } & 2.78 \text { miles } \\ & & \text { Travel time: } & 13 \text { to } 17 \text { days }\end{array}$

File names of the sequence of traces indicating a positive trace.
19960206.10
19960213.10
19960215.10
19960220.10
19960226.10

Remarks: The Eosine OJ peak in these eluted samples is partly obscured by an existing Fluorescein dye peak. 
Table A6. Summary for injection site and attempted recovery sites during dye-trace test T103-11

\begin{tabular}{|c|c|c|c|}
\hline Tracer injection date: & $02 / 27 / 96$ & $\begin{array}{l}\text { Tracer Test No: } \\
\text { Project No: }\end{array}$ & $\begin{array}{l}\text { T103-11 } \\
\text { MO-10300 }\end{array}$ \\
\hline \multicolumn{4}{|c|}{ Injection Site } \\
\hline $\begin{array}{l}\text { Site name: } \\
\text { County: } \\
\text { Quadrangle: } \\
\text { Altitude: }\end{array}$ & $\begin{array}{l}\text { Sinkhole } \# 19960212-01 \\
\text { Pulaski } \\
\text { Bloodland } \\
1,070 \pm 20 \text { feet }\end{array}$ & $\begin{array}{l}\text { Latitude: } \\
\text { Longitude: } \\
\text { Land net: } \\
\text { Quarter section: }\end{array}$ & $\begin{array}{l}374204 \\
0920925 \\
\text { sec. 5, T. } 34 \text { N, R. } 11 \mathrm{~W} \\
\text { NE } 1 / 4 \text { SE } 1 / 4 \text { NE 1/4; ADA }\end{array}$ \\
\hline $\begin{array}{l}\text { Site description: } \\
\text { Field conditions: } \\
\text { Hydrologic conditions: }\end{array}$ & \multicolumn{3}{|c|}{$\begin{array}{l}\text { Large sinkhole next to losing reach of Smith Branch north of Bloodland Lake, near Rang } \\
\text { Overcast with showers. Rained the night before injection. } \\
\text { ___low flow; __ high flow; __ high-base flow; __ low-base flow; __ flood flow }\end{array}$} \\
\hline $\begin{array}{l}\text { Tracing agent: } \\
\text { Agent quantity: } \\
\text { Time: }\end{array}$ & $\begin{array}{l}\text { Rhodamine WT } \\
2.5 \text { liters } \\
9: 15 \text { a.m. }\end{array}$ & $\begin{array}{l}\text { Pre-injection flush: } \\
\text { Post-injection flush: } \\
\text { Investigator(s): }\end{array}$ & $\begin{array}{l}\text { Rain runoff } \\
\text { Rain runoff } \\
\text { Brenden }\end{array}$ \\
\hline
\end{tabular}

Remarks: Dye injected into small opening in the southwest corner of the sinkhole. Surface runoff was used to flush dye into the ground.

Attempted Recovery Sites

\begin{tabular}{|c|c|c|c|c|c|}
\hline No. & Site name & $\begin{array}{l}\text { Latitude-longitude } \\
\text { (degrees minutes seconds) }\end{array}$ & $\begin{array}{l}\text { Sample } \\
\text { method }\end{array}$ & $\begin{array}{l}\text { Distance } \\
\text { (miles) }\end{array}$ & $\begin{array}{c}\text { Test } \\
\text { results }^{a}\end{array}$ \\
\hline 1 & Roubidoux Spring & $374931-0921205$ & Charcoal & 8.87 & $\mathrm{n}$ \\
\hline 2 & Tunnel Hollow Spring & $374745-0920926$ & Charcoal & 6.52 & $\mathrm{n}$ \\
\hline 3 & Ballard Hollow Stream near Laughlin Cemetery & $374636-0920948$ & Charcoal & 5.22 & $\mathrm{n}$ \\
\hline 4 & Roubidoux Creek site \#2 & $374644-0921007$ & Charcoal & 5.40 & $\mathrm{n}$ \\
\hline 5 & Miller Spring & $374204-0920414$ & Charcoal & 4.70 & $\mathbf{p}$ \\
\hline 6 & FLW-32 unnamed spring & $374359-0920542$ & Charcoal & 4.05 & $\mathrm{n}$ \\
\hline 7 & Sandstone Spring & $374416-0920451$ & Charcoal & 4.88 & $\mathrm{n}$ \\
\hline 8 & Stone Mill Spring & $374424-0920229$ & Charcoal & 6.89 & $\mathrm{n}$ \\
\hline 9 & Shanghai Spring & $374951-0920515$ & Charcoal & 9.66 & $\mathrm{n}$ \\
\hline 10 & Dry Creek & $374732-0920640$ & Charcoal & 6.76 & $\mathrm{n}$ \\
\hline
\end{tabular}

ap, positive dye detection; $n$, no dye detected. 
Table A7. Summary for successful dye recovery at Miller Spring during dye-trace test T103-11

\begin{tabular}{|c|c|c|c|}
\hline Tracer injection date: & $02 / 27 / 96$ & $\begin{array}{l}\text { Tracer Test No: } \\
\text { Project No: }\end{array}$ & $\begin{array}{l}\text { T103-11 } \\
\text { MO-10300 }\end{array}$ \\
\hline
\end{tabular}

Injection Site

$\begin{array}{llll}\text { Site name: } & \text { Sinkhole \#19960212-01 } & \text { Latitude: } & 374204 \\ \text { County: } & \text { Pulaski } & \text { Longitude: } & 0920925 \\ \text { Quadrangle: } & \text { Bloodland } & \text { Land net: } & \text { sec. 5, T. 34 N, R. 11 W } \\ \text { Altitude: } & 1,070 \pm 20 \text { feet } & \text { Quarter section: } & \text { NE 1/4 SE 1/4 NE 1/4; ADA }\end{array}$

Site description:

Large sinkhole next to losing reach of Smith Branch north of Bloodland Lake, near Range 31.

Field conditions:

Overcast with showers.

Hydrologic conditions:

_._. low flow; __ high flow; high-base flow; low-base flow; flood flow

Tracing agent:

Agent quantity:

Time:
Rhodamine WT

2.5 liters

9:15 a.m.
Pre-injection flush:

Post-injection flush:

Investigator(s):
Rain runoff

Rain runoff

Brenden

\section{Recovery Site}

$\begin{array}{llll}\begin{array}{l}\text { Site name: } \\ \text { County: }\end{array} & \text { Miller Spring } & \text { Latitude: } & 374204 \\ \begin{array}{l}\text { Quadrangle: } \\ \text { Altitude: }\end{array} & \text { Pulaski } & \text { Longitude: } & 0920414 \\ & \text { Big Piney } & \text { Land net: } & \text { sec. 6, T. 34 N, R. 10 W } \\ & 800 \text { feet } \pm 20 \text { feet } & \text { Quarter section: } & \text { SW 1/4 NW 1/4 NE 1/4; ABC } \\ \begin{array}{l}\text { Sampling method: } \\ \text { Analytical method: }\end{array} & \begin{array}{l}\text { Charcoal packet } \\ \text { Shimadzu RF5000u }\end{array} & \text { Trace length: } & 4.70 \text { miles } \\ & \text { Travel time: } & 12 \text { to 23 days }\end{array}$

File names of the sequence of traces indicating a possible positive trace.
19960304.06
19960311.06
19960322.06
19960404.06
19960424.06 
Table A8. Summary for injection site and attempted recovery sites during dye-trace test T103-12

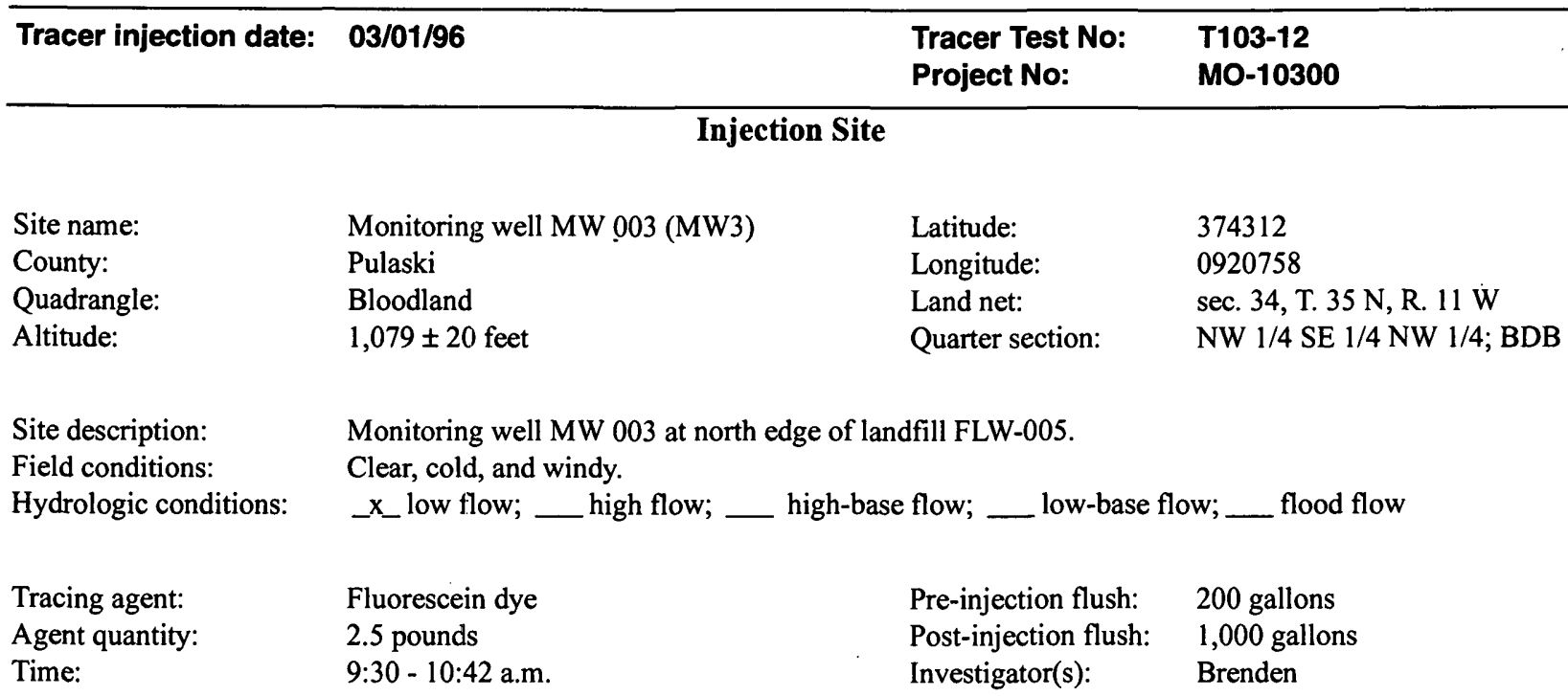

Remarks: Preflushed well with 200 gallons of water before injecting dye. Dye was injected while flushing with remaining water. Background concentrations of fluorescein dye at Shanghai Spring and Sandstone Spring were too large during this dye-trace test, thereby making the data interpretation inconclusive.

Attempted Recovery Sites

\begin{tabular}{|c|c|c|c|c|c|}
\hline No. & Site name & $\begin{array}{c}\text { Latitude-longitude } \\
\text { (degrees minutes seconds) }\end{array}$ & $\begin{array}{l}\text { Sample } \\
\text { method }\end{array}$ & $\begin{array}{l}\text { Distance } \\
\text { (miles) }\end{array}$ & $\begin{array}{l}\text { Test } \\
\text { results }^{a}\end{array}$ \\
\hline 1 & Roubidoux Spring & $374931-0921205$ & Charcoal & 8.17 & n \\
\hline 2 & Tunnel Hollow Spring & $374745-0920926$ & Charcoal & 5.41 & $\mathrm{n}$ \\
\hline 3 & Ballard Hollow Stream & $374636-0920948$ & Charcoal & 4.27 & $\mathrm{n}$ \\
\hline 4 & Roubidoux Creek site \#2 & $374644-0921007$ & Charcoal & 4.53 & $\mathrm{n}$ \\
\hline 5 & Miller Spring & $374204-0920414$ & Charcoal & 3.62 & $\mathrm{n}$ \\
\hline 6 & FLW-32 unnamed spring & $374359-0920542$ & Charcoal & 2.27 & $\mathrm{n}$ \\
\hline 7 & Sandstone Spring & $374416-0920451$ & Charcoal & 3.11 & $\mathrm{n}$ \\
\hline 8 & Stone Mill Spring & $374424-0920229$ & Charcoal & 5.21 & $\mathrm{n}$ \\
\hline 9 & Shanghai Spring & $374951-0920515$ & Charcoal & 8.00 & $\mathrm{n}$ \\
\hline 10 & Old ammunition dump well & $374313-0920710$ & Charcoal & 1.01 & $\mathrm{n}$ \\
\hline
\end{tabular}

$\mathrm{a}_{\mathrm{n}, \mathrm{no}}$ dye detected. 
Table A9. Summary for injection site and attempted recovery sites during dye-trace test T103-13

\begin{tabular}{llll}
\hline Tracer injection date: & $\mathbf{0 1 / 0 8 / 9 7}$ & $\begin{array}{l}\text { Tracer Test No: } \\
\text { Project No: }\end{array}$ & $\begin{array}{l}\text { T103-13 } \\
\text { MO-10300 }\end{array}$ \\
\hline & & Injection Site & \\
& & & \\
Site name: & Smith Branch losing reach & Latitude: & 374156 \\
County: & Pulaski & Longitude: & 0920919 \\
Quadrangle: & Bloodland & Land net: & sec. 4, T. 34 N, R. 11 W \\
Altitude: & $1,040 \pm 20$ feet & Quarter section: & NW 1/4 SW 1/4 NW 1/4; BCB
\end{tabular}

Site description: $\quad$ Losing reach of Smith Branch 0.5 mile downstream from Bloodland Lake-near Range 31.

Field conditions: Cold with snow falling.

Hydrologic conditions: _ _ _ low flow; __ high flow; __ high-base flow; __ low-base flow; __ flood flow

$\begin{array}{llll}\text { Tracing agent: } & \text { Rhodamine WT } & \text { Pre-injection flush: } & \text { Streamflow } \\ \text { Agent quantity: } & 2.5 \text { liters } & \text { Post-injection flush: } & \text { Streamflow } \\ \text { Time: } & 2: 00 \text { p.m. } & \text { Investigator(s): } & \text { Brenden/Schumacher }\end{array}$

Remarks: Dye was injected into the streambed of Smith Branch about 10 feet upstream of a losing reach near sinkhole \#19960212-01.

Attempted Recovery Sites

\begin{tabular}{|c|c|c|c|c|c|}
\hline No. & Site name & $\begin{array}{l}\text { Latitude-longitude } \\
\text { (degrees minutes seconds) }\end{array}$ & $\begin{array}{l}\text { Sample } \\
\text { method }\end{array}$ & $\begin{array}{l}\text { Distance } \\
\text { (miles) }\end{array}$ & $\begin{array}{l}\text { Test } \\
\text { results }^{a}\end{array}$ \\
\hline 1 & Roubidoux Spring & $374931-0921205$ & Charcoal & 9.06 & $\mathrm{n}$ \\
\hline 2 & Miller Spring & $374204-0920414$ & Charcoal & 4.61 & $\mathbf{p}$ \\
\hline 3 & FLW-32 unnamed spring & $374359-0920542$ & Charcoal & 4.06 & $\mathrm{n}$ \\
\hline 4 & Sandstone Spring & $374416-0920451$ & Charcoal & 4.88 & $\mathrm{n}$ \\
\hline 5 & Shanghai Spring & $374951-0920515$ & Charcoal & 9.77 & $\mathrm{n}$ \\
\hline 6 & Blank & Not applicable (n/a) & Charcoal & $\mathrm{n} / \mathrm{a}$ & $\mathrm{n}$ \\
\hline 7 & Dry Creek & $374732-0920640$ & Charcoal & 6.88 & $\mathrm{n}$ \\
\hline
\end{tabular}

ap, positive dye detection; $\mathbf{n}$, no dye detected. 
Table A10. Summary for successful dye recovery at Miller Spring during dye-trace test T103-13

\begin{tabular}{llll}
\hline Tracer injection date: & $01 / 08 / 97$ & Tracer Test No: & T103-13 \\
& & Project No: & MO-10300
\end{tabular}

\section{Injection Site}

$\begin{array}{llll}\text { Site name: } & \text { Losing stream, near sinkhole \#19960212-01 } & \text { Latitude: } & 374156 \\ \text { County: } & \text { Pulaski } & \text { Longitude: } & 0920919 \\ \text { Quadrangle: } & \text { Bloodland } & \text { Land net: } & \text { sec. 4, T. 34 N, R. 11 W } \\ \text { Altitude: } & 1,040 \pm 20 \text { feet } & \text { Quarter section: } & \text { NW 1/4 SW 1/4 NW 1/4; BCB }\end{array}$

Site description:

Field conditions:

Hydrologic conditions:

Tracing agent:

Agent quantity:

Time:

Losing 0.5 mile reach of Smith Branch—stream north of Bloodland Lake. Cold with snow falling.

_. _ low flow; __ high flow; high-base flow; low-base flow; flood flow

Rhodamine WT

2.0 liters

2:00 p.m.
Pre-injection flush: Post-injection flush:
Streamflow Investigator(s):
Brenden/Schumacher

\section{Recovery Site}

Site name:

County:

Quadrangle:

Altitude:

Sampling method: Analytical method:
Miller Spring

Pulaski

Big Piney

800 feet \pm 20 feet

Charcoal packet

Shimadzu RF5000u
Latitude: $\quad 374204$

Longitude: $\quad 0920414$

Land net: $\quad$ sec. 6, T. 34 N, R. $10 \mathrm{~W}$

Quarter section: $\quad$ SW $1 / 4$ NW 1/4 NE 1/4; ABC

Trace length: $\quad 4.61$ miles

Travel time: $\quad 20$ to 25 days

File names of the sequence of traces indicating a possible positive trace.

$\begin{array}{lll}19960121.06 & 19960128.06 & 19960203.06 \\ 19960212.06 & 19960224.06 & \end{array}$


Table A11. Summary for injection site and attempted recovery sites during dye-trace test T103-14

\begin{tabular}{llll}
\hline Tracer injection date: & $\mathbf{0 1 / 2 3 / 9 7}$ & Tracer Test No: & T103-14 \\
& & Project No: & M0-10300 \\
\hline
\end{tabular}

\section{Injection Site}

$\begin{array}{llll}\text { Site name: } & \text { Monitoring well MW 003 at FLW-005 } & \text { Latitude: } & 374312 \\ \text { County: } & \text { Pulaski } & \text { Longitude: } & 0920758 \\ \text { Quadrangle: } & \text { Bloodland } & \text { Land net: } & \text { sec. 34, T. 35 N, R. 11 W } \\ \text { Altitude: } & 1,079 \pm 20 \text { feet } & \text { Quarter section: } & \text { NW 1/4 SE 1/4 NW 1/4; BDB }\end{array}$

Site description: $\quad$ Monitoring well MW 003 at north edge of landfill FLW-005.

Field conditions: $\quad$ Cold and windy.

Hydrologic conditions: _ _ _ _ low flow; __ high flow; __ high-base flow; __ low-base flow; __ flood flow

Tracing agent: $\quad$ Fluorescein dye Pre-injection flush: 200 gallons

Agent quantity: $\quad 3.5-4.0$ pounds $\quad$ Post-injection flush: 4,000 gallons

Time: 9:00 a.m. $\quad$ Investigator(s): Brenden

Remarks: Injection was into monitoring well MW 003, also designated MW3, located on the north edge of landfill FLW-005. Preflushed well with 200 gallons of water. Returned to well on January 28, 1997, and flushed well with an additional 4,000 gallons of water.

Attempted Recovery Sites

\begin{tabular}{llcccc}
\hline & \multicolumn{1}{c}{ Site name } & $\begin{array}{c}\text { Latitude-longitude } \\
\text { (degrees minutes seconds) }\end{array}$ & $\begin{array}{c}\text { Sample } \\
\text { method }\end{array}$ & $\begin{array}{c}\text { Distance } \\
\text { (miles) }\end{array}$ & $\begin{array}{c}\text { Test } \\
\text { results }\end{array}$ \\
\hline & & & & & \\
$\mathbf{a}$
\end{tabular}

${ }^{2} \mathrm{p}$, positive dye detection; $\mathrm{n}$, no dye detected; $u$, uncertain (inconclusive results). 
Table A12. Summary for successful dye recovery at Sandstone Spring during dye-trace test T103-14

\begin{tabular}{llll}
\hline Tracer injection date: & $\mathbf{0 1 / 2 3 / 9 7}$ & $\begin{array}{l}\text { Tracer Test No: } \\
\text { Project No: }\end{array}$ & $\begin{array}{l}\text { T103-14 } \\
\text { MO-10300 }\end{array}$
\end{tabular}

\begin{tabular}{|c|c|c|c|}
\hline \multicolumn{4}{|c|}{ Injection Site } \\
\hline $\begin{array}{l}\text { Site name: } \\
\text { County: } \\
\text { Quadrangle: } \\
\text { Altitude: }\end{array}$ & $\begin{array}{l}\text { Monitoring well MW } 003 \text { at FLW-005 } \\
\text { Pulaski } \\
\text { Bloodland } \\
1,079 \pm 20 \text { feet }\end{array}$ & $\begin{array}{l}\text { Latitude: } \\
\text { Longitude: } \\
\text { Land net: } \\
\text { Quarter section: }\end{array}$ & $\begin{array}{l}374312 \\
0920758 \\
\text { sec. } 34, \text { T. } 35 \text { N, R. } 11 \text { W } \\
\text { NW 1/4 SE } 1 / 4 \text { NW } 1 / 4\end{array}$ \\
\hline $\begin{array}{l}\text { Site description: } \\
\text { Field conditions: } \\
\text { Hydrologic conditions: }\end{array}$ & \multicolumn{3}{|c|}{$\begin{array}{l}\text { Monitoring well at the north edge of landfill FLW-005. } \\
\text { Cold and windy. } \\
\text { _.__low flow; __ high flow; __ high-base flow; __ low-base flow; __ flood flow }\end{array}$} \\
\hline $\begin{array}{l}\text { Tracing agent: } \\
\text { Agent quantity: } \\
\text { Time: }\end{array}$ & $\begin{array}{l}\text { Fluorescein dye } \\
3.5-4.0 \text { pounds } \\
\text { 9:00 a.m. }\end{array}$ & $\begin{array}{l}\text { Pre-injection flush: } \\
\text { Post-injection flush: } \\
\text { Investigator(s): }\end{array}$ & $\begin{array}{l}200 \text { gallons } \\
4,000 \text { gallons } \\
\text { Brenden }\end{array}$ \\
\hline \multicolumn{4}{|c|}{ Recovery Site } \\
\hline $\begin{array}{l}\text { Site name: } \\
\text { County: } \\
\text { Quadrangle: } \\
\text { Altitude: }\end{array}$ & $\begin{array}{l}\text { Sandstone Spring } \\
\text { Pulaski } \\
\text { Big Piney } \\
825 \text { feet }\end{array}$ & $\begin{array}{l}\text { Latitude: } \\
\text { Longitude: } \\
\text { Land net: } \\
\text { Quarter section: }\end{array}$ & $\begin{array}{l}374416 \\
0920451 \\
\text { sec. 24, T. } 35 \text { N, R. } 11 \mathrm{~W} \\
\text { SE 1/4 SE 1/4 SE 1/4; CCC }\end{array}$ \\
\hline $\begin{array}{l}\text { Sampling method: } \\
\text { Analytical method: }\end{array}$ & $\begin{array}{l}\text { Activated coconut charcoal } \\
\text { Scanning spectrofluorophotometer }\end{array}$ & $\begin{array}{l}\text { Trace length: } \\
\text { Travel time: }\end{array}$ & $\begin{array}{l}3.11 \text { miles } \\
20 \text { to } 26 \text { days }\end{array}$ \\
\hline \multicolumn{4}{|c|}{ File names of the sequence of traces indicating a positive dye recovery. } \\
\hline & $\begin{array}{l}19970113.08 \\
19970203.08 \\
19970224.08\end{array}$ & $\begin{array}{l}19970 \\
19970\end{array}$ & $\begin{array}{l}28.08 \\
18.08\end{array}$ \\
\hline
\end{tabular}


Table A13. Summary for injection site and attempted recovery sites during dye-trace test T103-15

\begin{tabular}{llll}
\hline Tracer injection date: & $02 / 28 / 97$ & $\begin{array}{l}\text { Tracer Test No: } \\
\text { Project No: }\end{array}$ & $\begin{array}{l}\text { T103-15 } \\
\text { MO-10300 }\end{array}$ \\
\hline
\end{tabular}

\section{Injection Site}

$\begin{array}{llll}\text { Site name: } & \text { Sinkhole \#19970224-01 by FLW 15 } & \text { Latitude: } & 374347 \\ \text { County: } & \text { Pulaski } & \text { Longitude: } & 0920705 \\ \text { Quadrangle: } & \text { Big Piney } & \text { Land net: } & \text { sec. 26, T. 35 N, R. 11 W } \\ \text { Altitude: } & 1,100 \pm 20 \text { feet } & \text { Quarter section: } & \text { SW 1/4 SW 1/4 NW 1/4; BCC }\end{array}$

Site description:

Field conditions:

Hydrologic conditions:

Tracing agent:

Agent quantity:

Time:

Newly opened sinkhole about 100 feet east of road FLW 15.

Sunny and mild.

_. flood flow

$\begin{array}{lll}\text { Rhodamine WT } & \text { Pre-injection flush: } & 200 \text { gallons } \\ \text { 4.0 liters } & \text { Post-injection flush: } & 1,800 \text { gallons } \\ \text { 9:00 a.m. } & \text { Investigator(s): } & \text { Brenden }\end{array}$

Remarks: Flushing water was provided by the Fort Leonard Wood fire department. Dye was injected into the southeast corner of the sinkhole while flushing water was being added.

Attempted Recovery Sites

\begin{tabular}{|c|c|c|c|c|c|}
\hline No. & Site name & $\begin{array}{l}\text { Latitude-longitude } \\
\text { (degrees minutes seconds) }\end{array}$ & $\begin{array}{l}\text { Sample } \\
\text { method }\end{array}$ & $\begin{array}{l}\text { Distance } \\
\text { (miles) }\end{array}$ & $\begin{array}{l}\text { Test } \\
\text { results }^{a}\end{array}$ \\
\hline 1 & Roubidoux Spring & $374931-0921205$ & Charcoal & 8.00 & $\mathrm{n}$ \\
\hline 2 & Miller Spring & $374204-0920414$ & Charcoal & 3.25 & $\mathrm{n}$ \\
\hline 3 & FLW-32 unnamed spring & $374359-0920542$ & Charcoal & 1.28 & $\mathrm{n}$ \\
\hline 4 & FLW-32 lower spring & $374416-0920451$ & Charcoal & 1.53 & $\mathrm{n}$ \\
\hline 5 & Asphalt plant site stream & $374347-0920517$ & Charcoal & 2.03 & $\mathrm{n}$ \\
\hline 6 & Sandstone Spring & $374416-0920451$ & Charcoal & 2.11 & $\mathrm{n}$ \\
\hline 7 & Shanghai Spring & $374951-0920515$ & Charcoal & 7.12 & $\mathrm{n}$ \\
\hline 8 & Ammunition dump well & $374313-0920710$ & Charcoal & .68 & $\mathrm{n}$ \\
\hline
\end{tabular}

an, no dye detected. 
Table A14. Summary for injection site and attempted recovery sites during dye-trace test T103-16

\begin{tabular}{llll}
\hline Tracer injection date: & $\mathbf{0 5 / 3 0 / 9 7}$ & $\begin{array}{l}\text { Tracer Test No: } \\
\text { Project No: }\end{array}$ & $\begin{array}{l}\text { T103-16 } \\
\text { MO-10300 }\end{array}$
\end{tabular}

\section{Injection Site}

$\begin{array}{llll}\text { Site name: } & \text { Forney Army Airport-North } & \text { Latitude: } & 374433 \\ \text { County: } & \text { Pulaski } & \text { Longitude: } & 0920802 \\ \text { Quadrangle: } & \text { Bloodland } & \text { Land net: } & \text { sec. 22, T. 35 N, R. 11 W } \\ \text { Altitude: } & 1,075 \pm 10 \text { feet } & \text { Quarter section: } & \text { SE 1/4 NW 1/4 SW 1/4; CBD }\end{array}$

Site description:

Field conditions:

Hydrologic conditions:

Tracing agent:

Agent quantity:

Time:

Rhodamine WT

3:00 p.m. cave collapse.

Large sinkhole north of Forney Army Airfield, about 100-feet diameter domed interior-probable

Light to moderately intense rainfall for several hours before dye injection. low flow; _ _ _ high flow; __ high-base flow; __ low-base flow; __ flood flow

Remarks: Flushing water was provided by the Fort Leonard Wood fire department. This injection was part of the Shanghai Spring storm-event discharge and water-quality investigation. Dye was recovered from Shanghai Spring in water samples collected using a Sigma automatic sampler and Sutron data recorder. The dye concentration peak at Shanghai Spring occurred 98 hours after dye injection.

Attempted Recovery Sites

\begin{tabular}{|c|c|c|c|c|c|}
\hline No. & Site name & $\begin{array}{l}\text { Latitude-longitude } \\
\text { (degrees minutes seconds) }\end{array}$ & $\begin{array}{l}\text { Sample } \\
\text { method }\end{array}$ & $\begin{array}{l}\text { Distance } \\
\text { (miles) }\end{array}$ & $\begin{array}{l}\text { Test } \\
\text { results }^{a}\end{array}$ \\
\hline & Shanghai Spring & $374951-0920515$ & Water & 6.55 & $\mathbf{p}$ \\
\hline
\end{tabular}

${ }^{a}$ p, positive dye detection. 
Table A15. Summary for successful dye recovery at Shanghai Spring during dye-trace test T103-16

\begin{tabular}{llll}
\hline Tracer injection date: & $05 / 30 / 97$ & Tracer Test No: & T103-16 \\
& & Project No: & MO-10300
\end{tabular}

\section{Injection Site}

$\begin{array}{llll}\text { Site name: } & \text { Forney Army Airport-North } & \text { Latitude: } & 374433 \\ \text { County: } & \text { Pulaski } & \text { Longitude: } & 0920802 \\ \text { Quadrangle: } & \text { Bloodland } & \text { Land net: } & \text { sec. 22, T. 35 N, R. 11 W } \\ \text { Altitude: } & 1,075 \pm 10 \mathrm{feet} & \text { Quarter section: } & \text { SE 1/4 NW 1/4 SW 1/4; CBD }\end{array}$

Site description: Large sinkhole north of Forney Army Airfield, about 100-feet diameter domed interior-probable cave collapse.

Field conditions: Light to moderately intense rainfall for several hours before dye injection.

Hydrologic conditions: __ low flow; _ _ _ high flow; __ high-base flow; __ low-base flow; __ flood flow

Tracing agent: $\quad$ Rhodamine WT

Agent quantity:

Time:
Pre-injection flush: Rain

Post-injection flush: 1,500 gallons

Investigator(s): $\quad$ Schumacher

\section{Recovery Site}

$\begin{array}{llll}\text { Site name: } & \text { Shanghai Spring } & \text { Latitude: } & 374951 \\ \text { County: } & \text { Pulaski } & \text { Longitude: } & 0920515 \\ \text { Quadrangle: } & \text { Devils Elbow } & \text { Land net: } & \text { sec. 24, T. 36 N, R. 11 W } \\ \text { Altitude: } & 750 \text { feet } \pm 20 \text { feet } & \text { Quarter section: } & \text { NW 1/4 NE 1/4 SW 1/4; CAB } \\ & & & \\ \text { Sampling method: } & \text { Water samples } & \text { Trace length: } & 6.55 \text { miles } \\ \text { Analytical method: } & \text { Shimadzu RF5000u } & \text { Travel time: } & 98 \text { hours }\end{array}$

File names of the sequence of traces indicating a positive dye recovery.

$\begin{array}{lll}\text { fw970602.03f } & f w 970602.04 f & f w 970603.05 f \\ \text { fw970603.06f } & \text { fw970603.07f } & \text { fw970603.08f } \\ \text { fw970603.09f } & \text { fw970604.10f } & \text { fw970604.11f } \\ \text { fw970604.12f } & \text { fw970604.01g } & \text { fw970604.02g }\end{array}$


Table A16. Summary for injection site and attempted recovery sites during dye-trace test T103-17

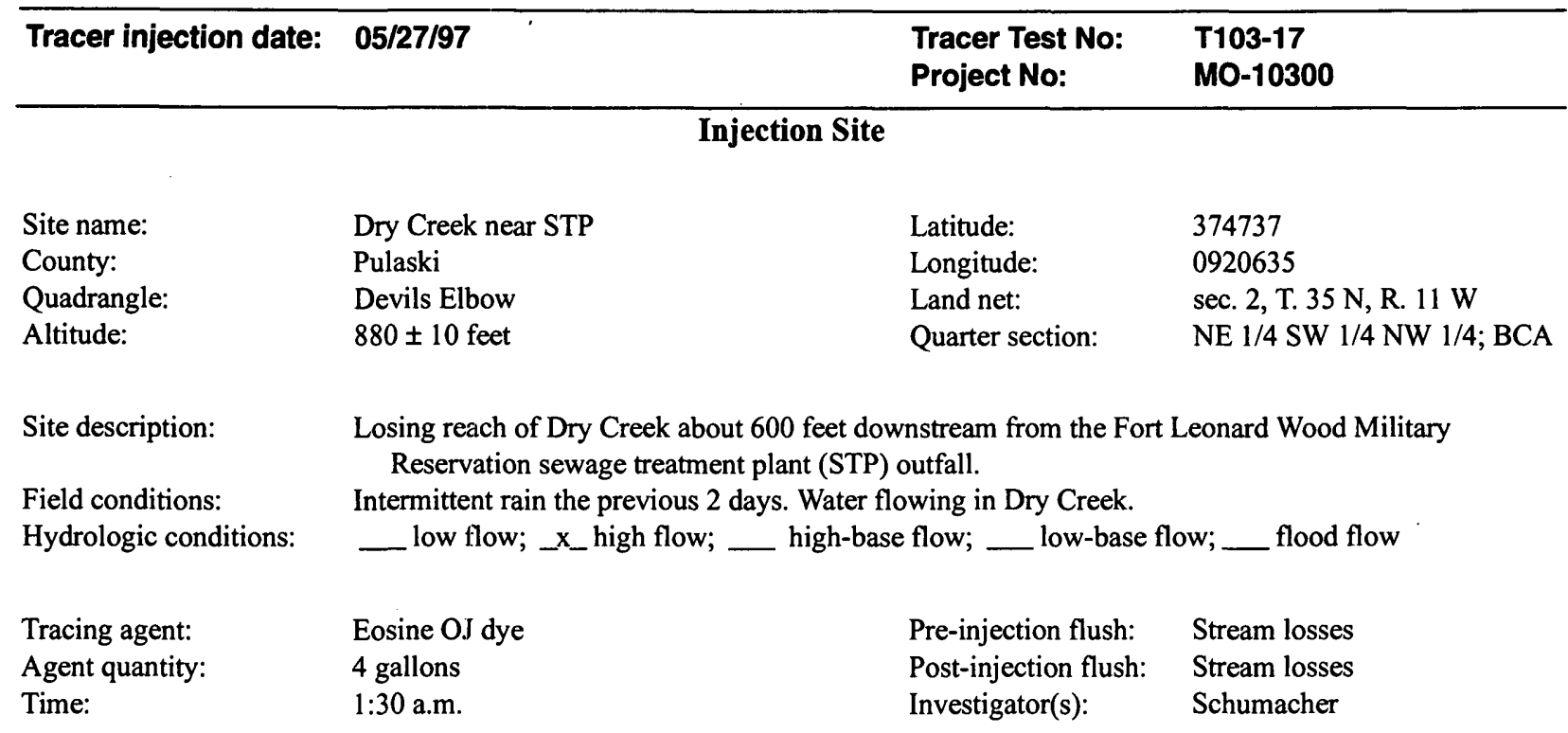

Remarks: Dye placed in Dry Creek near known cavity in streambed that receives all streamflow under low-flow conditions.

Attempted Recovery Sites

\begin{tabular}{|c|c|c|c|c|c|}
\hline No. & Site name & $\begin{array}{l}\text { Latitude-longitude } \\
\text { (degrees minutes seconds) }\end{array}$ & $\begin{array}{l}\text { Sample } \\
\text { method }\end{array}$ & $\begin{array}{l}\text { Distance } \\
\text { (miles) }\end{array}$ & $\begin{array}{l}\text { Test } \\
\text { results }\end{array}$ \\
\hline 1 & Shanghai Spring & $374951-0920515$ & Water & 2.78 & $\mathbf{p}$ \\
\hline
\end{tabular}

ap, positive dye detection. 
Table A17. Summary for successful dye recovery at Shanghai Spring during dye-trace test T103-17

Tracer Test No:

Project No:
T103-17

MO-10300

\section{Injection Site}

$\begin{array}{llll}\text { Site name: } & \text { Dry Creek near STP } & \text { Latitude: } & 374737 \\ \text { County: } & \text { Pulaski } & \text { Longitude: } & 0920635 \\ \text { Quadrangle: } & \text { Devils Elbow } & \text { Land net: } & \text { sec. 2, T. 35 N, R. 11 W } \\ \text { Altitude: } & 880 \pm 10 \text { feet } & \text { Quarter section: } & \text { NE 1/4 SW 1/4 NW 1/4; BCA }\end{array}$

Site description:

Field conditions:

Hydrologic conditions:

Tracing agent:

Agent quantity:

Time:
Losing stream about 600 feet downstream from the Fort Leonard Wood Military Reservation sewage treatment plant (STP) outfall.

Intermittent rain the previous 2 days. Water flowing in Dry Creek.

_ low flow; _. flood flow

\section{Recovery Site}

Site name:

County:

Quadrangle:

Altitude:

Sampling method:

Analytical method:
Shanghai Spring

Pulaski

Devils Elbow

750 feet \pm 20 feet

Water samples

Shimadzu RF5000u

$\begin{array}{ll}\text { Pre-injection flush: } & \text { Stream losses } \\ \text { Post-injection flush: } & \text { Stream losses } \\ \text { Investigator(s): } & \text { Schumacher }\end{array}$

Latitude:

Longitude:

Land net:

374951

0920515

Quarter section:

sec. 24, T. $36 \mathrm{~N}, \mathrm{R} .11 \mathrm{~W}$

NW 1/4 NE 1/4 SW 1/4; CAB

Trace length:

2.78 miles

Travel time:

File names of the sequence of traces indicating a positive dye recovery.

$\begin{array}{lll}\text { fw970529.04c } & \text { fw970530.12c } & \text { fw970530.03d } \\ \text { fw970531.07d } & \text { fw970531.01e } & \text { fw970601.07e }\end{array}$

fw970602.02f 
Table A18. Summary for injection site and attempted recovery sites during dye-trace test T103-18

\begin{tabular}{|c|c|c|c|}
\hline Tracer injection date: & $06 / 13 / 97$ & $\begin{array}{l}\text { Tracer Test No: } \\
\text { Project No: }\end{array}$ & $\begin{array}{l}\text { T103-18 } \\
\text { MO-10300 }\end{array}$ \\
\hline \multicolumn{4}{|c|}{ Injection Site } \\
\hline $\begin{array}{l}\text { Site name: } \\
\text { County: } \\
\text { Quadrangle: } \\
\text { Altitude: }\end{array}$ & $\begin{array}{l}\text { Smith Branch near mouth } \\
\text { Pulaski } \\
\text { Waynesville } \\
880 \pm 10 \text { feet }\end{array}$ & $\begin{array}{l}\text { Latitude: } \\
\text { Longitude: } \\
\text { Land net: } \\
\text { Quarter section: }\end{array}$ & $\begin{array}{l}374610 \\
0921109 \\
\text { sec. 7, T. } 35 \text { N, R. 11 W } \\
\text { SW 1/4 SE 1/4 SW 1/4; CDC }\end{array}$ \\
\hline $\begin{array}{l}\text { Site description: } \\
\text { Field conditions: } \\
\text { Hydrologic conditions: }\end{array}$ & \multicolumn{3}{|c|}{ 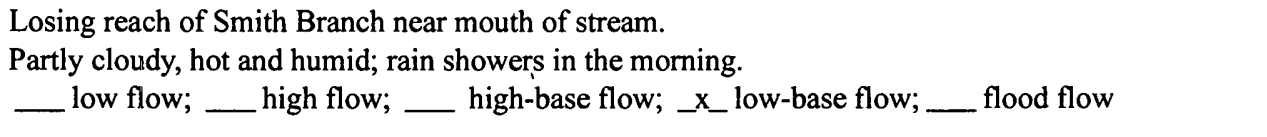 } \\
\hline $\begin{array}{l}\text { Tracing agent: } \\
\text { Agent quantity: } \\
\text { Time: }\end{array}$ & $\begin{array}{l}\text { Rhodamine WT } \\
4.0 \text { liters } \\
\text { 12:50 p.m. }\end{array}$ & $\begin{array}{l}\text { Pre-injection flush: } \\
\text { Post-injection flush: } \\
\text { Investigator(s): }\end{array}$ & $\begin{array}{l}\text { Streamflow } \\
\text { Streamflow } \\
\text { Brenden }\end{array}$ \\
\hline
\end{tabular}

Attempted Recovery Sites

\begin{tabular}{|c|c|c|c|c|c|}
\hline No. & Site name & $\begin{array}{l}\text { Latitude-longitude } \\
\text { (degrees minutes seconds) }\end{array}$ & $\begin{array}{l}\text { Sample } \\
\text { method }\end{array}$ & $\begin{array}{l}\text { Distance } \\
\text { (miles) }\end{array}$ & $\begin{array}{l}\text { Test } \\
\text { results }^{a}\end{array}$ \\
\hline 1 & Roubidoux Spring & $374931-0921205$ & Charcoal & 3.93 & $\mathrm{n}$ \\
\hline 2 & Ballard Hollow Stream near Laughlin Cemetery & $374636-0920948$ & Charcoal & 1.30 & $\mathrm{n}$ \\
\hline 3 & Smith Branch & $374604-0921107$ & Charcoal & .11 & $\mathrm{n}$ \\
\hline 4 & Shanghai Spring & $374951-0920515$ & Charcoal & 6.77 & $\mathrm{n}$ \\
\hline 5 & Blank & Not applicable (n/a) & Charcoal & $\mathrm{n} / \mathrm{a}$ & $\mathrm{n}$ \\
\hline
\end{tabular}

an, no dye detected. 
Table A19. Summary for injection site and attempted recovery sites during dye-trace test T002-01

\begin{tabular}{llll}
\hline Tracer injection date: & $06 / 17 / 97$ & Tracer Test No: & T002-01 \\
& & Project No: & MO-00200 \\
\hline
\end{tabular}

\section{Injection Site}

$\begin{array}{llll}\text { Site name: } & \text { Smith Branch - Site 3 } & \text { Latitude: } & 374313 \\ \text { County: } & \text { Pulaski } & \text { Longitude: } & 0921030 \\ \text { Quadrangle: } & \text { Bloodland } & \text { Land net: } & \text { sec. 32, T. 35 N, R. 11 W } \\ \text { Altitude: } & 1,100 \pm 10 \text { feet } & \text { Quarter section: } & \text { NW 1/4 SW 1/4; DA }\end{array}$

Site description: $\quad$ Normandy Training Area emergency spillway at sediment pond 3.

Field conditions: Intermittent rain throughout the day.

Hydrologic conditions: _ _ low flow; __ high flow; _ _ _ high-base flow; __ low-base flow; __ flood flow

Tracing agent: $\quad$ Fluorescein dye Pre-injection flush: None

Agent quantity: 4 gallons $\quad$ Post-injection flush: None

Time: 12:01 p.m. Investigator(s): Southard

Remarks: Injection was into 1 to 2 cubic feet per second flow from Normandy Training Area emergency spillway at sediment pond 3 at the junction of the spillway and Smith Branch.

Attempted Recovery Sites

\begin{tabular}{llllll}
\hline \multicolumn{1}{c}{ No. } & \multicolumn{1}{c}{ Site name } & $\begin{array}{c}\text { Latitude-longitude } \\
\text { (degrees minutes seconds) }\end{array}$ & $\begin{array}{c}\text { Sample } \\
\text { method }\end{array}$ & $\begin{array}{c}\text { Distance } \\
\text { (miles) }\end{array}$ & $\begin{array}{c}\text { Test } \\
\text { results }\end{array}$ \\
\hline & & & & & \\
$\mathbf{1}$ & Shanghai Spring & $\mathbf{3 7 4 9 5 1 - 0 9 2 0 5 1 5}$ & Water & $\mathbf{8 . 9 0}$ & $\mathbf{p}$ \\
2 & Roubidoux Spring & $374931-0921205$ & Charcoal & 7.38 & $\mathrm{n}$ \\
3 & Ballard Hollow Spring & $374830-0921056$ & Charcoal & 3.51 & $\mathrm{n}$ \\
$\mathbf{4}$ & Smith Branch Stream near mouth & $\mathbf{3 7 4 5 5 5 - 0 9 2 1 1 0 1}$ & Charcoal & $\mathbf{3 . 3 5}$ & $\mathbf{p}$ \\
\hline
\end{tabular}

${ }^{a} \mathrm{p}$, positive dye detection; $\mathrm{n}$, no dye detected. 
Table A20. Summary for successful dye recovery at Shanghai Spring during dye-trace test T002-01

\begin{tabular}{|c|c|c|c|}
\hline Tracer injection date: & $06 / 17 / 97$ & $\begin{array}{l}\text { Tracer Test No: } \\
\text { Project No: }\end{array}$ & $\begin{array}{l}\text { T002-01 } \\
\text { MO-00200 }\end{array}$ \\
\hline \multicolumn{4}{|c|}{ Injection Site } \\
\hline $\begin{array}{l}\text { Site name: } \\
\text { County: } \\
\text { Quadrangle: } \\
\text { Altitude: }\end{array}$ & $\begin{array}{l}\text { Smith Branch - Site } 3 \\
\text { Pulaski } \\
\text { Bloodland } \\
1,100 \pm 10 \text { feet }\end{array}$ & $\begin{array}{l}\text { Latitude: } \\
\text { Longitude: } \\
\text { Land net: } \\
\text { Quarter section: }\end{array}$ & $\begin{array}{l}374313 \\
0921030 \\
\text { sec. } 32 \text {, T. } 35 \text { N, R. } 11 \mathrm{~W} \\
\text { NW 1/4 SW 1/4; DA }\end{array}$ \\
\hline $\begin{array}{l}\text { Site description: } \\
\text { Field conditions: } \\
\text { Hydrologic conditions: }\end{array}$ & \multicolumn{3}{|c|}{$\begin{array}{l}\text { Normandy Training Area emergency spillway at sediment pond } 3 . \\
\text { Intermittent rain throughout the day. } \\
\text { low flow; __ high flow; _ } x_{-} \text {high-base flow; __ low-base flow; __ flood flow }\end{array}$} \\
\hline $\begin{array}{l}\text { Tracing agent: } \\
\text { Agent quantity: } \\
\text { Time: }\end{array}$ & $\begin{array}{l}\text { Fluorescein dye } \\
4 \text { gallons } \\
\text { 12:01 p.m. }\end{array}$ & $\begin{array}{l}\text { Pre-injection flush: } \\
\text { Post-injection flush: } \\
\text { Investigator(s): }\end{array}$ & $\begin{array}{l}\text { Streamflow } \\
\text { Streamflow } \\
\text { Southard }\end{array}$ \\
\hline
\end{tabular}

\section{Recovery Site}

$\begin{array}{llll}\text { Site name: } & \text { Shanghai Spring } & \text { Latitude: } & 374951 \\ \text { County: } & \text { Pulaski } & \text { Longitude: } & 0920515 \\ \text { Quadrangle: } & \text { Devils Elbow } & \text { Land net: } & \text { sec. 24, T. 36 N, R. 11 W } \\ \text { Altitude: } & 750 \text { feet } \pm 20 \text { feet } & \text { Quarter section: } & \text { NW 1/4 NE 1/4 SW 1/4 } \\ & & & \\ \text { Sampling method: } & \text { Water samples } & \text { Trace length: } & 8.90 \text { miles } \\ \text { Analytical method: } & \text { Scanning spectrofluorophotometer } & \text { Travel time: } & 15.9 \text { days }\end{array}$

File names of the sequence of traces indicating a positive dye recovery.
fw970627.03s
fw970701.05t
fw970629.10s
fw970630.02t
fw970711.10w
fw970703.09t fw970707.10w 
Table A21. Summary for successful dye recovery at Smith Branch during dye-trace test T002-01

\begin{tabular}{llll}
\hline Tracer injection date: & $\mathbf{0 6 / 1 7 / 9 7}$ & $\begin{array}{l}\text { Tracer Test No: } \\
\text { Project No: }\end{array}$ & $\begin{array}{l}\text { T002-01 } \\
\text { MO-00200 }\end{array}$ \\
\hline
\end{tabular}

\section{Injection Site}

$\begin{array}{llll}\text { Site name: } & \text { Smith Branch - Site 3 } & \text { Latitude: } & 374313 \\ \text { County: } & \text { Pulaski } & \text { Longitude: } & 0921030 \\ \text { Quadrangle: } & \text { Bloodland } & \text { Land net: } & \text { sec. 32, T. 35 N, R. 11 W } \\ \text { Altitude: } & 1,100 \pm 10 \text { feet } & \text { Quarter section: } & \text { NW 1/4 SW 1/4; DA }\end{array}$

Site description:

Field conditions:

Hydrologic conditions:

Tracing agent:

Agent quantity:

Time:

\author{
Smith Branch - Site 3 \\ Bloodland
}

Normandy Training Area emergency spillway at sediment pond 3.

Intermittent rain throughout the day.

low flow; __ high flow; _ $x_{-}$high-base flow; __ low-base flow; __ flood flow

Fluorescein dye

4 gallons

12:01 p.m.

\author{
Pre-injection flush: Streamflow \\ Post-injection flush: Streamflow \\ Investigator(s): $\quad$ Southard
}

\section{Recovery Site}

Site name:

County:

Quadrangle:

Altitude:

Sampling method: Analytical method:
Smith Branch mouth

Pulaski

Waynesville

820 feet \pm 10 feet

Charcoal

Scanning spectrofluorophotometer

$\begin{array}{ll}\text { Latitude: } & 374604 \\ \text { Longitude: } & 0921107\end{array}$

Land net:

Quarter section:

sec. 18 , T. 35 N, R. 11 W

NW 1/4 NE 1/4 NW 1/4; BAB

Trace length: $\quad 3.35$ miles

Travel time: $\quad$ Less than 1 day

File names of the sequence of traces indicating a positive dye recovery.

$\begin{array}{lll}19970612.05 & 19970618.05 & 19970620.05 \\ 19970627.05 & \end{array}$




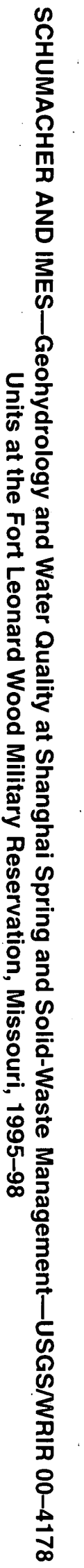

